
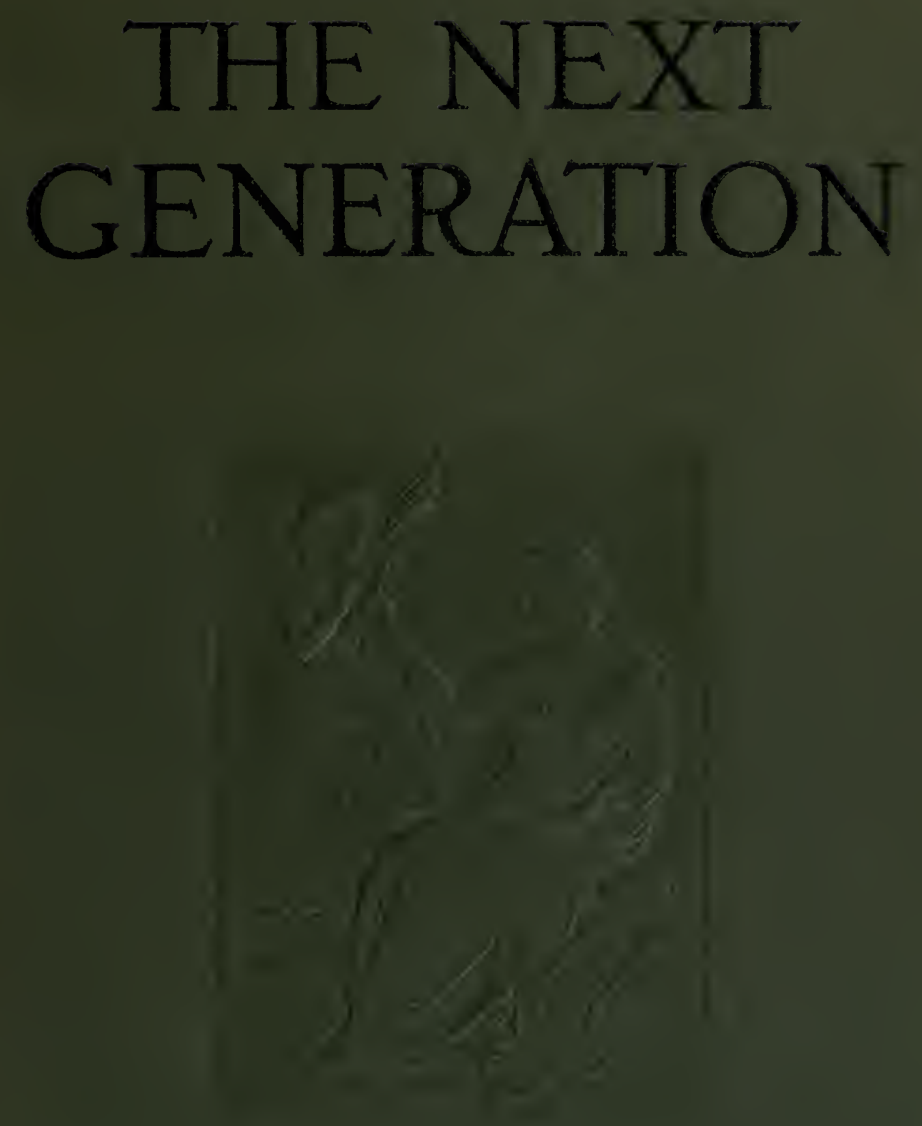

FRANCES GULICK JEWETT 




\title{
THE NEXT GENERATION
}

\section{A STUDY IN THE PHYSIOLOGY OF INHERITANCE}

\author{
BY \\ FRANCES GULICK JEWETT \\ AUTHOR OF THE FOLLOWING BOOKS OF THE GULICK HYGIENE SERIES \\ "GOOD HEALTH," "TOWN AND CITY," "THE BODY AT WORK," \\ "THE BODY AND ITS DEFENSES," AND "CONTROL OF BODY AND MIND"
}


COPYRIGHT, 1914, BY FRANCES GULICK JEWETT

ALL RIGHTS RESERVED

514.9 
TO

BOYS AND GIRLS

THE GUARDIANS

OF THE NEXT GENERATION 



\section{ACKNOWLEDGMENT}

In offering this small volume to those who may read it the author wishes to express her own indebtedness, not alone to the men and to the women whose books have supplied her with facts and with inspiration, but also to relatives and personal friends who have shared in her work as counselors, and to authorities of distinguished attainment who have given the manuscript careful reading. Among these should be mentioned Professor Irving Fisher of Yale University, Professor W. L. Tower and Professor G. H. Mead of The University of Chicago, Professor Thomas M. Balliet of New York University, Dr. Luther H. Gulick of New York City, and Professor Adolf Meyer of the Johns Hopkins University.

Acknowledgment is also made to authors and to publishers through whose kindness many of the illustrations of this book have become possible; also to Mr. Victor David Brenner for permission to represent on the cover his medallion, "The Successors to the Fates." Having been designed for the Fifteenth International Congress of Hygiene and Demography, this emblem most appropriately shows that "the distaff from which is spun the thread of life is held to-day by the forces of modern hygiene."

FRANCES GULICK JEWETT 



\section{CONTENTS}

PAGF

INTRODUCTION

CHAPTER

I. Fathers, Mothers, ANd Children . . . . . . I

II. Andalusian Fowls . . . . . . . . . . . 7

III. When Characters ARE Combined . . . . . . I 2

IV. Mendel and his Garden Peas . . . . . . . 20

V. Laws of Inheritance put to Use . . . . . . 26

VI. Evolution of the Horse . . . . . . . . . 34

VII. A FEW OF DARIIN'S FACTS . . . . . . . . . 43

Vili. Dariwin's Problem . . . . . . . . . . . . 49

IX. Five Links to the Chain . . . . . . . . 56

X. Evidences of Evolution . . . . . . . . . 64

XI. Acquired Characters and Mutations . . . . 72

XII. Isolation, or Land Shells on Hawail . . . 8 I

XiII. Changed Environment for Leptinotarsa. . . 88

XIV. New Species through Changed Environment • 95

$\mathrm{XV}$. Beginnings of the Next Generation . . . 100

XVI. The Marvel of Growth . . . . . . . . . Iio

XVíl. Germ Cells damaged by Alcohol. . . . . 118

XViII. Fron Fourteen to Twenty. . . . . . . . 126

XiX. Nicotine and Adolescence . . . . . . 136

XX. Alcohol as a Beverage . . . . . . . 145

XXI. The Crown of Evolution . . . . . . . 153

XXII. Family Responsibility . . . . . . . . . I62

XXili. Protect the Stream of Life . . . . . . 165 
viii

\section{THE NEXT GENERATION}

CHAPTER

PAGE

XXIV. Prevention of Blindness . . . . . . . I73

XXV. Safety from Feeble-mindedness. . . . . . I8I

XXVI. Overwork For Children ONe Hundred Years Ago and Now . . . . . . . . . . . . 189

XXVII. Three Steps in Race Improvement . . . . . 196

XXViII. The Final Step, or Race Regeneration . . 2OI

QUESTIONS . . . . . . . . . . . . . 205

A PARTIAL LIST OF BOOKS USED IN THE PREPARA-

TION OF THIS VOLUME . . . . . . . . . . 229 INDEX . . . . . . . . . . . . . . $23 \mathrm{I}$ 


\section{INTRODUCTION}

In the days of myths in ancient Greece men talked about three Fates who were sisters. And in Rome an artist ${ }^{1}$ painted these sisters as they were supposed to bethree old women in a group, controlling the destiny of every human being.

As they stand together in the picture they neither weep nor smile; they show neither joy nor sorrow, neither hope nor despair. Each is working, watching, waiting.

Clotho is the youngest sister. She holds the

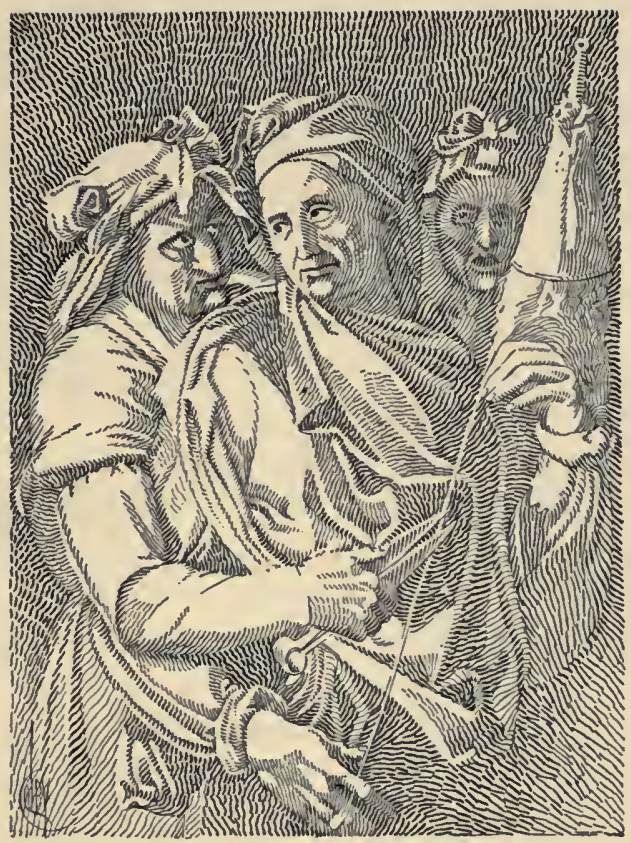

The Three Fates distaff which carries the thread of life. This thread begins to lengthen when the baby is born. Lachesis, the second sister,

1 Supposed to have been Michelangelo. 
spins out the thread as the years go by; and Atropos, the third sister Fate, stands by with huge shears. She is the oldest, the most haggard, the most cruel of them all, and she threatens the thread from the moment the spinning begins until she decides to cut it.

Sometimes she clips her shears together and cuts when the thread has lengthened no more than a hand's breadth. This means that the baby dies very young. Sometimes the thread grows longer and longer, until yards of it have been spun off by Lachesis. This means that, although Atropos continued to threaten with her shears, she did not actually bring them together until years had passed and the baby had grown to be a man.

The teaching of the picture of the myth is that human beings of every age, in every generation, are but the playthings of the Fates - that life is longer or shorter as the Fates decide, and that no act of man can change either his own destiny or that of his descendants.

Here, then, is the difference between ancient myth and modern science. Nowadays science declares that man is by no means altogether helpless concerning his own future — that only the fool believes he cannot help himself. And, laden with facts to prove each point, science goes on to show how man may shorten his life or lengthen it, how he may bless his life or curse it, how he may make his life or mar it, by what he knows and by the way he puts his knowledge to use.

Science does not stop even here, but, with proofs in hand, shows that the destiny of future generations lies in the hands of the men and the women, the boys and the girls, who are alive to-day.

"This book deals with the same absorbing topic. It tries to show how it is that science has crippled those ancient Fates, 
and why it is that a man who understands the laws of growth and of inheritance may, in a very real way, drive the crippled Fates from the field and help shape the future of the race.

Some one has suggested that the three Fates of modern life are

I. Heredity — what we receive from our ancestors by the road of inheritance.

2. Environment - all that surrounds us and influences us from the cradle to the grave.

3. Personal development - what we make of ourselves during life.

The analogy is not altogether perfect, but the following pages take each of these modern Fates into account.

To understand inheritance we must follow life from prehistoric ages until now. From small beginnings we must trace large results - must learn how it is and why it is that all life on the earth is joined as a unit, and must know how life is passed on from generation to generation.

We must even study'life cells in their development, and watch them as they grow from stage to stage, until at last they become well-developed beings.

In other words, we must learn so many facts about life itself and about what controls it, that we shall be better prepared to face our own lives and the lives of future generations.

Science says human beings will be safer when people know the facts and are influenced by them. Teachers say, "Give us the facts and we will pass them on to the boys and the girls whom we teach." Both scientist and teacher agree that the human race will be better able to escape certain kinds of peril if we let young people know what the perils are and how to avoid them.

Such is the purpose of this book. 
Hitherto the development of our race has been unconscious, and we have been allowed no responsibility for its right course. Now, in the fullness of time, we are treated as children no more, and the conscious fashioning of the human race is given into our hands. Let us put away childish things, stand up with open eyes, and face our responsibilities.

WHETHAM 


\section{THE NEXT GENERATION}

\section{CHAPTER I}

FATHERS, MOTHERS, AND CHILDREN

At our county fair recently the animal that drew the crowd and won the prize was a huge Poland-China pig. He weighed twelve hundred pounds, measured seven full feet in length, was coal black with white feet and a white face, and had ears that flapped low. He had a turned-up nose, a curled-up tail, legs barely long enough to hold his body from the ground, and he cost exactly three thousand dollars.

"But why did you pay so much ?" we asked the owner.

"For three reasons," he said.

I. "The pig has a fine line of ancestors.

2. "He shows it in every part of his body.

3. "His descendants are sure to be like him and to bring fancy prices."

From this man's point of view it was indeed clear that for the sake of the next generation even pigs must have the right sort of ancestors.

And what about human beings, we wondered - the people next door. and the rest of us? Does the law apply to us all ? We thought them over, one by one, - neighbors to the north and to the south, to the east and to the west of us, - men, women, and children who are set apart in families, with each family quite different from all the others. 
Yet we knew that if a student of the laws of inheritance should come to town, and if he should hear certain definite facts about the ancestors of these neighbors, even without a glance at the men and the women themselves, or at their children, he would be able to go from door to door and nail on most of them a few definite statements about the children

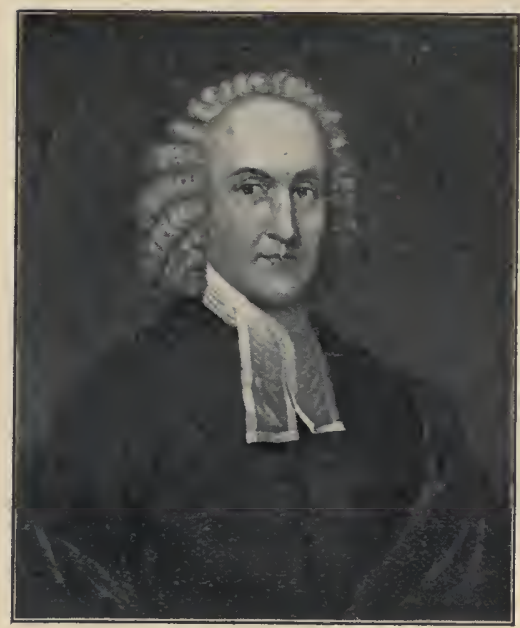

JONATHAN EDWARDS in the house.

One label might read: "Every child here has light hair and blue eyes." Another : "Every child in this family has dark hair and dark eyes." Another : "Most of the children unusually bright." Still another : "Children dark-skinned with curly hair."

And then if the same student should go to the small house around the corner, and should know what the parents and the grandparents of the children have been, the paper nailed to the door would read: "Every child in this family is either idiotic or feeble-minded."

It is true that in many cases even the closest students of inheritance would not be able to make definite statements about color of hair, eyes, etc. Nevertheless, when all the doors had been labeled, those who read the statements would see that most of them told the truth about the children.

Later chapters will show how it comes about that men are able to speak so positively about persons whom they have 
never seen. We know this is done. Perhaps, however, we hardly appreciate the tremendous power of the laws which tie the generations together.

Take, for example, the record of the family of Jonathan Edwards. He himself was born in I 703. He was noted for his strength of character, for his mental power, and for his fearless loyalty to duty.

Such was the character stamp which he had when he began to be an ancestor. As to whether or not his own character made any difference with the character of his descendants, nothing but facts will show, and here are some of them. ${ }^{1}$ In I 900, of the descendants of Jonathan Edwards, I 394 had been located, and the occupations of many were ascertained. The following facts are quoted.

College presidents

College professors

Doctors .

Clergymen, missionaries, etc. . . . . . . . . . 100

Officers in the army and navy . . . . . . . . . 75

Eminent authors and writers . . . . . . . . 60

Lawyers . . . . . . . . . . . . over 100

Judges . . . . . . . . . . . . . . . . 30

Holders of public offices, one being Vice President of the United States. . . . . . . . . . . . 80

United States senators . . . . . . . . . . . . 3

Managers of railroads, banks, insurance companies, etc. 15

College graduates . . . . . . . . . . . 295

Several were governors and holders of important state offices.

The claim is also made that "almost if not every department of social progress and of public weal has felt the impulse of this healthy and long-lived family."

1 Taken from Mr. Winship's account of the descendants of Jonathan Edwards. 
The following statement touches another point. "It is not known that any one of them was ever convicted of crime."

Such; then, is the well-authenticated record of a single family, living in the United States of America. Clearly enough, the world is better off because Jonathan Edwards became an ancestor.

Take another American family, with another kind of fame. The "Jukes family" 1 it is called. The first discovered ancestor of this group was a shiftless fisherman born in New York state in 1720 . He had five daughters, and in the five generations since then the family has numbered I 200 persons. This includes 200 outsiders who have married into the family. Follow the occupations of some of these people. The facts are quoted from the printed record.

Convicted criminals . . . . . . . . . . . I30

Habitual thieves . . . . . . . . . . . . 60

Murderers . . . . . . . . . . . . . . 7

Wrecked by diseased wickedness . . . . . . 440

Immoral women . . . . . . . . . fully one half

Professional paupers . . . . . . . . . . . . 310

Trades learned by twenty. Ten of these learned the trade in prison.

Think also of this other fact which the report brings out: During the years of their lives not paupers alone but also those who had committed robbery and murder and broken every law of decency had to be supported at public expense. That is to say, law-abiding and efficient citizens - those who stayed out of prison and out of the workhouse, those who worked hard with honest purpose to support themselves had to pay taxes for the support of these lawless and inefficient people who spent their days in prison and in the workhouse.

1 Not the real family name. 


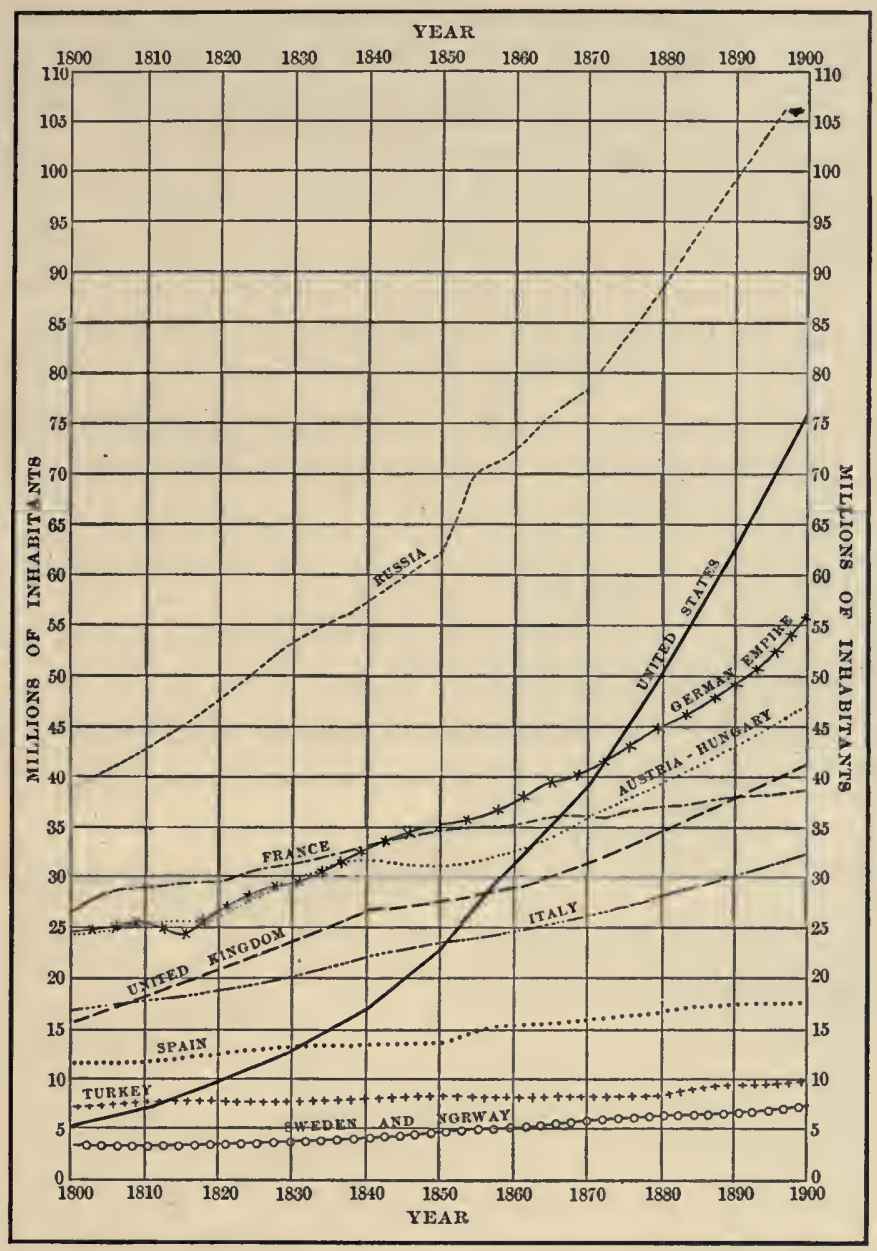

Rate of Increase of Population in Different Countries (From "Statistical Atlas," Twelfth Census of the United States) 
It is estimated that already this single family of Jukes has cost the state of New York over $\$ 1,250,000$; and the expense still goes on, for each generation of descendants continues to be what its ancestors were.

In the United States as a whole those of us who are ablebodied, clear-headed, and diligent are taxed over \$I00,000,ooo each year for the support of criminals, paupers, the insane, the feeble-minded, and the diseased. This does not include the enormous sums paid out by ourselves in private charities. More serious still, thousands of those who were cursed from birth by the quality of their ancestors and by the surroundings in which they grew up are themselves now a curse to their descendants and to the communities in which they live.

No wonder, then, that the relation of cause to effect in life is being studied now as never before in the history of the world. The truth is that there was never such an array of facts to show what the trouble is and how to escape it.

Examine the chart which shows the rate of increase in national populations. Notice what is happening in the different countries of the world. See how the millions of the inhabitants piled themselves up between the years I 800 and 1900. Imagine this rate of increase as it goes on for the next hundred years; then think of the difference it will make in the outcome of things whether one kind of family or the other kind multiplies faster on the earth.

The next few chapters give facts which show what the laws of inheritance are - laws which apply not only to poultry and to guinea pigs but to all living creatures, including man. 


\section{CHAPTER II}

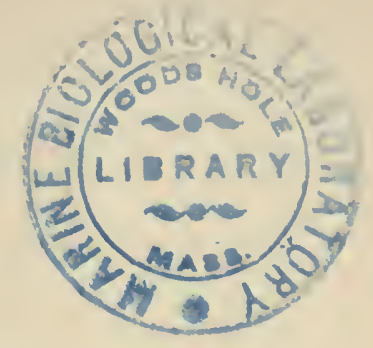

\section{ANDALUSIAN FOWLS}

Selected eggs were in the incubator, and the men who owned them waited to see what the chicks would look like. It seems there are two distinct kinds of Andalusian fowls, - one pure-bred black, the other pure-bred white with dashes of black here and there, - and the owners had selected one bird from each group to be parents of the next generation of chicks.

The question was whether these chicks would be black like one parent or white like the other parent, or whether they would show a mixture of the two colors.

The answer came after the little creatures were hatched. Not a black one or a white

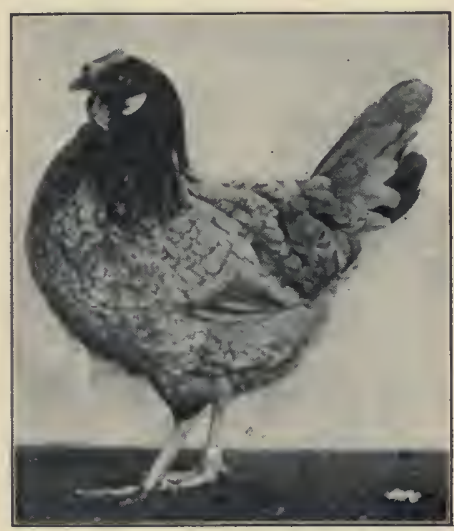

Blue Andalusian Pullet

The chickens come in three colors : blue, black, and white; the larger number being blue

one appeared among them; each was a queer mixture of black and white which is technically called blue.

Was this an accident, the breeders wondered, or would the same thing happen over again if other Andalusian parents were chosen? So they made another test. In the first experiment the father was black, the mother white. Now they 
changed the order. They chose a pure-bred white father and a pure-bred black mother. Again they waited for results, and again the chicks told the same story. Not a black one or a white one was among them; all were as blue as the first group.

From then until now the same experiment has always produced the same result. Whenever a black Andalusian

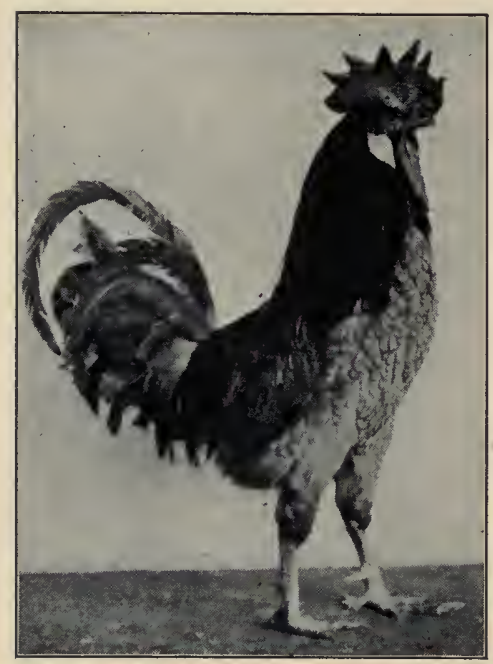

Blue Andalusian Cock fowl and a white Andalusian fowl have become parents, their chicks in the first generation have always grown up to be blue Andalusian fowls. They are a mixture and not pure-bred like their parents. Such a mixture is always called hybrid. Remember this word and its meaning. It is the opposite of pure-bred. All animals are hybrid unless both parents are purebred of the same kind.

The next step in this investigation was to gather facts about the descendants of the hybrids. Would they be blue like their parents or black like one grandparent or white like the other grandparent?

In making this experiment two blue ones were chosen as ancestors.

The illustration shows what happened in the next generation. One chick was white like one grandparent; one was black like the other grandparent; two were blue like their parents. 
Follow the illustration on the next page and see what came to pass when the different members of that mixed group of chicks became ancestors.

The black one was mated with a black one from another family - not shown in the picture. Eggs were laid. These hatched out in proper fashion, and behold, every chick of the next generation was as black as its parents; not one was blue like its grandparents.

The white one was also mated with another white one from another family, and here the chicks in the next generation were all as white as their parents, with not a blue one among them to remind themselves of their blue grandparents.

But when the blue ones were mated with others like themselves, their children turned out precisely as did the children of the hybrids of the previous generation. That is, out of every four, one chick was black, one was white, and two were blue.

These experiments have been repeated over and over again in different parts of the world, and the results are always the same. Stated concisely, they are as follows:

I. When a pure-bred black Andalusian fowl is mated with a pure-bred black, all the descendants are pure-bred black; and so long as black is mated with black, no white one and no blue one will ever appear in any generation of the family.

2. When a pure-bred white Andalusian fowl is mated with a pure-bred white, all the descendants are white; and if white continues to be mated with white, no black one and no blue one will ever appear in later generations of the family.

3. When a pure-bred white is mated with a pure-bred black, not a member of the next generation will be pure-bred; not one will be either black or white; each will be a hybrid and each will be blue. 
4. When a blue Andalusian fowl is mated with another blue hybrid like itself, one quarter of the offspring will be white, another quarter will be black, while the remaining half will be hybrid and will show it by being blue. ${ }^{1}$ "

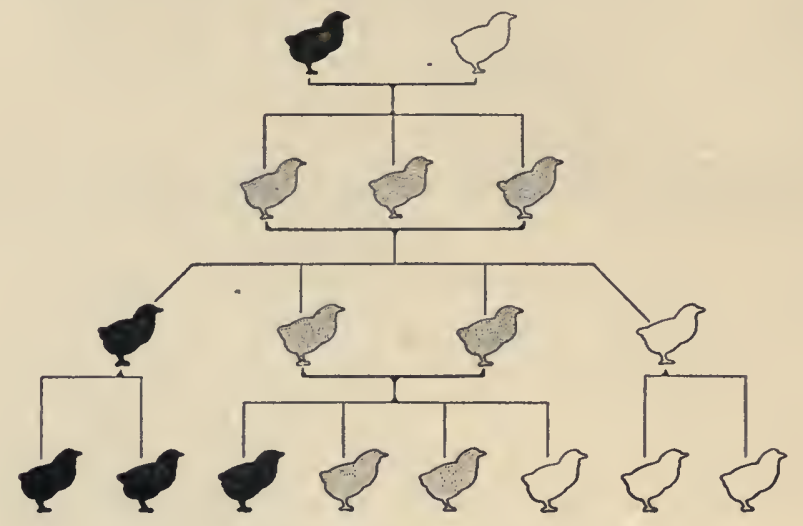

Color Inheritance in Andalusian Fowls

Follow the descendants of the first two and notice what occurs in successive generations when a pure-bred black Andalusian fowl and a pure-bred white Andalusian fowl become ancestors. In studying the illustration remember that, in the second generation of offspring, the black one and the white one are mated with pure-breds like themselves, which are not shown in the drawing

With Andalusian fowls these laws of color inheritance never vary. They can always be depended upon. They continue from generation to generation, and by knowing who the

1 The number of individuals in the diagram for each generation does not mean that there are always just so many chicks in each family. Instead, the number is chosen for no other purpose than to show the proportion of black and white and blue that comes in each generation of descendants when a black Andalusian fowl is mated with a white Andalusian fowl. Moreover, it is not meant that every family of four has one white, one black, and two blue chicks, but only that this is true on the average. There is just one chance in four that an egg will hatch out a white chick, one chance in four that the chick will be black, and one chance in two that it will be blue. 
Andalusian ancestors are one can always tell what the color of the descendants will be.

But inheritance is not always such an easy affair to follow. On the contrary, Andalusian fowls simply help us by showing what the laws are in their simplest form. We shall soon see that these same laws are in control even when inheritance seems nothing more than a tangled skein of chances. Take the guinea pig, for example. Here combinations occur which would be pretty hard to understand if it were not for Andalusian fowls. The next chapter deals with these guinea pigs. 


\section{CHAPTER III}

\section{WHEN CHARACTERS ${ }^{1}$ ARE COMBINED}

Between 1900 and 1905 about three thousand guinea pigs and several hundred rabbits were reared and housed and studied in the Zoölogical Laboratory of Harvard University. Professor Castle kept them in this laboratory of living creatures for the sake of seeing what he could do for descendants when he himself chose ancestors for them.

His main work was with guinea pigs, and he chose them because they are small, because they do not eat much, do not take up much room, are easily cared for, and multiply fast.

Perhaps the last reason was really the most important of all. The truth is, small animals have so short a time from one generation to the next - that is, from parent to child - that it is easy to trace resemblances between far-away ancestors and present-day descendants. ${ }^{2}$

Rabbits have a new generation every eight months, and guinea pigs multiply at the rate of four generations a year. This means that guinea pigs can have children, grandchildren, great-grandchildren, and great-great-grandchildren all within the same year. Thus guinea pigs are particularly well fitted to serve as helpers in answering questions about inheritance, for within a very few years the descendants show just what their long lines of ancestors have done for them.

In size these animals are about as large as well-developed rats. But instead of being all of one color, as are rats, the

1 As used in books of this kind the word character means "characteristic."

2 All children of the same parent belong to the same generation. 
coats of guinea pigs show black, white, chocolate, yellow, or a mixture of certain shades of these different colors. For instance, spots of yellow-red and of blue-black, also dashes of black and of white, often occur in different combinations. But no combination of colors taught Dr. Castle plainer lessons

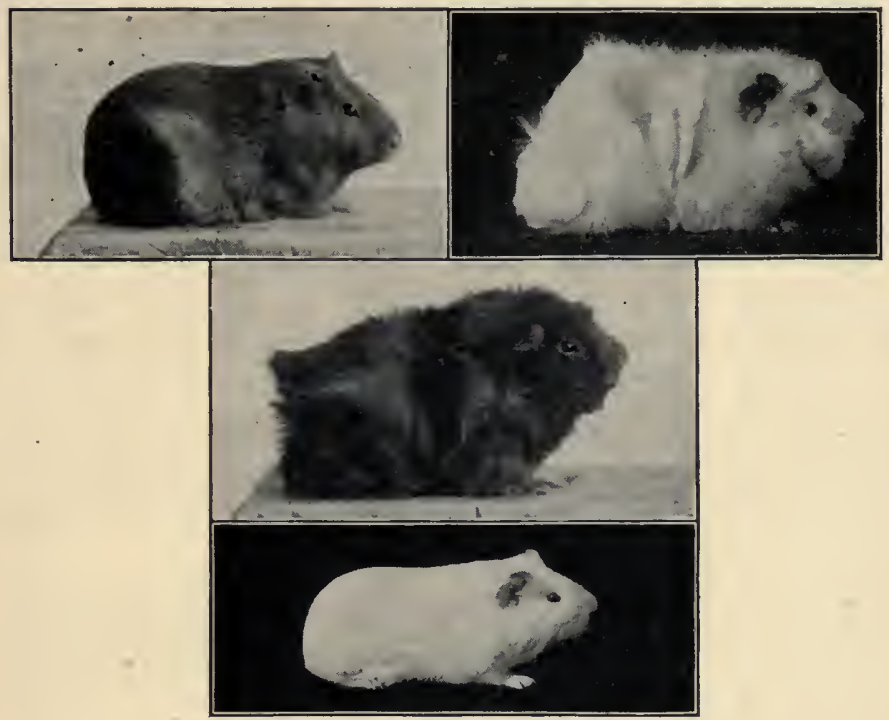

Guinea Pigs and their Descendants

A dark, smooth mother and a rough albino father are at the top. Below is their son. He is black because, in guinea-pig inheritance, black is dominant over white; he is rough because rough coat is dominant over smooth coat. At the bottom is a smooth, white grandchild of the black and the white grandparents. (After Castle, 1905.) Publication 23, Carnegie Institution

of inheritance than those which he learned from guinea pigs that were plain black and plain white. Still, even these were more or less interesting according to another character of the coat that covered them. For some the coat was rough as a rug, with spots here and there that looked like "cowlicks" 
or rosettes ; others, both the long-haired and the short-haired, had coats smooth like silk. Some had fur so short that each separate hair stayed in place without being brushed; others had hair so long that it could be combed and parted and brushed from side to side. Indeed, the length of hair for a full-grown guinea pig runs all the way from less than two inches on some to over six inches on others.

But whatever the character of the fur, whether long or short, black or white, rough or smooth, Dr. Castle found that each one of these characters was transmitted from ancestor to descendant in accordance with definite laws, and that the laws themselves are quite like those which control the descendants of Andalusian fowls.

At first sight this seems to be hardly true. Take, for example, his black guinea pigs mated with white albino ${ }^{1}$ guinea pigs. Judging by Andalusian fowls, we should expect to see a row of small blue guinea pigs in the next generation. But study the diagram and see what actually happened. One parent was pure-bred black, the other was pure-bred albino white, yet every child of theirs was as black as its black parent. Not a blue one or a white one was found anywhere among them. It looked as if each had inherited from its black parent alone - as if the white parent had not been taken into account at all. Still we know that every guinea pig in the row was bound to be hybrid; we know there was no escape for them, because, one and all, they were the children of two different kinds of pure-bred parents.

2 "An albino is an animal with unpigmented eyes and with little or no pigment in its coat." - Castle. The eyes of an albino are pink because there is no pigment in the iris. The color of the blood vessels therefore shines through it. Albino guinea pigs always have pink eyes. There are white guinea pigs with black eyes. These are not albino. In this chapter it is the albino white that are mentioned. The other white ones are not pure-bred. 
Why, then, were these hybrids black and not blue ? Simply because, with guinea pigs, black is the so-called dominant color. This means that when one parent is black and the other parent white, and when the two colors are therefore

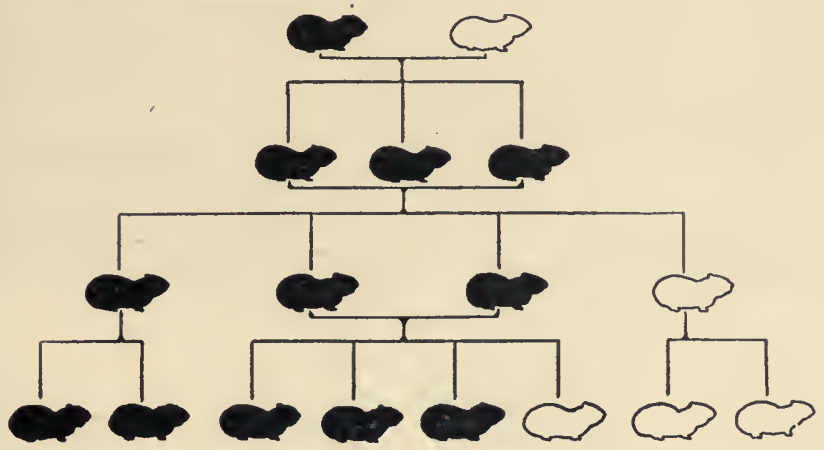

Color Inheritance in Guinea Pigs

Although pure-bred black guinea pigs and hybrid black guinea pigs look alike, they are really different, and this difference appears in the color of their children. When a pair of black guinea pigs have only black children, we know the parents are purebred; but when a pair of black guinea pigs have white children as well as black ones, we know their parents are hybrids. Study the illustration upwards from children to parents and decide which ancestors are pure, which hybrid. In doing this remember that in the second generation of offspring the black one and the white one are mated with pure-breds like themselves, which are not shown in the drawing. As you study the illustration keep the following facts in mind: 1. Pure-bred black mated with white gives black in every member of the next generation. Still each is as distinctly hybrid as are the Andalusian fowls. 2. All are black and not blue, because, with guinea pigs, black is the dominant, white the recessive character. 3 . Whenever a white guinea pig appears as the offspring of two black guinea pigs, we know that the parents were hybrids. (Find them in the illustration.) For this reason we can never tell whether a black guinea pig is pure or hybrid until we have seen its offspring. 4. Whenever all the children of two black guinea pigs are black, we know that at least one of the parents was pure. (Find them in the drawing.) 5. Whenever a white guinea pig mates with a white one, all the offspring are sure to be white. Compare this illustration with that of the Andalusian fowls. Note the differences

to be passed on by inheritance to later generations of guinea pigs, the black dominates in the immediate next generation. The white color, on the other hand, is recessive; that is, it recedes from sight and does not appear in any member 
of that next generation. These two words, dominant and recessive, are to be remembered, because, as we shall see later, they help us understand why one character and not another makes its appearance in succeeding generations.

As we already know, with Andalusian fowls neither black nor white is either dominant or recessive. As a result, when the two are mated, the color of the next generation is neither black nor white, but a mixture of the two, and every member of the young family is blue.

With guinea pigs, however, black dominates in such highhanded fashion that white is crowded entirely out of sight in the next family of descendants. White is therefore called the recessive color. Even hybrids among them are black. Study the illustration to see what occurs in each successive generation.

Notice that the children of black hybrid guinea pigs are of three sorts, even as are the children of blue hybrid Andalusian fowls.

ON THE AVERAGE,
OUT OF EVERY FOUR $\left\{\begin{array}{l}\text { One is pure-bred white, like its white grandparent. } \\ \text { One is pure-bred black, like its black grandparent. } \\ \text { Two are hybrid black, like the parents. }\end{array}\right.$

It is evident, then, that nature does not always label children so clearly as Andalusian fowls are labeled. Nevertheless, in both cases the same great laws hold true for ancestors and descendants alike.

Now go a step further. Dr. Castle tells us that color is not the only character which moves along in definite fashion, by definite laws. He says that when he mates a roughcoated guinea pig with one that has a smooth coat, all the little guinea pigs of the next generation, whether they are white or black, brown or yellow, have rough coats ; not one among them is smooth-coated. This means that rough coat is the dominant character and smooth coat the recessive character. 
Again, when he takes a pure-bred guinea pig with short hair and gives it a mate with long hair, each small guinea pig in the next generation, whatever its color may be, has short hair. This means that short hair is dominant, long hair recessive. Thus it turns out that, with guinea pigs, as

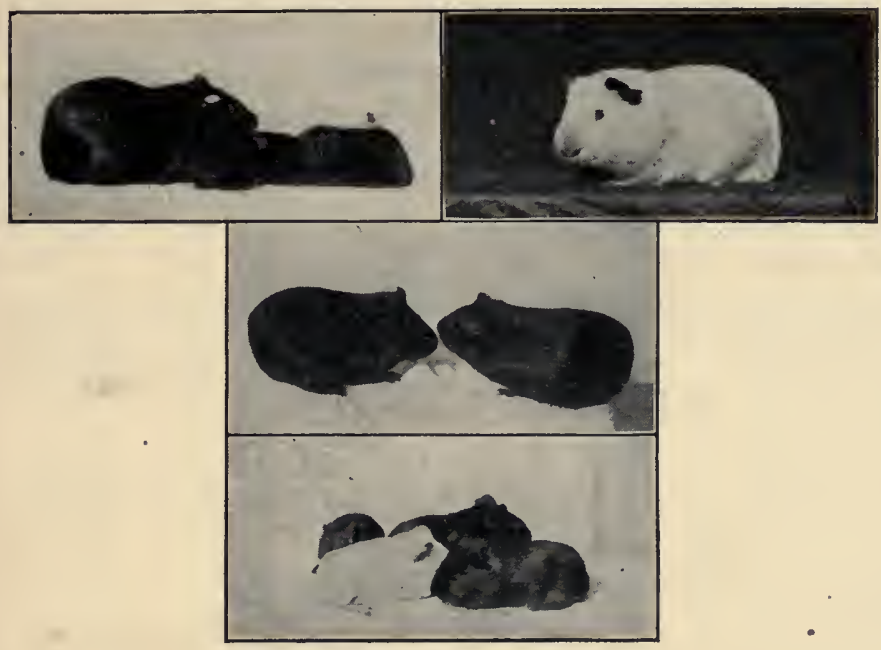

Three Generations of Guinea Pigs

The first row shows a white, smooth-coated father, a black, smooth-coated mother, and their children. Each one of these is black and has a smooth coat. The second row shows a pair of these black hybrid children. The third row shows grandchildren who were children of the hybrids. Notice the white one among them. It resembles its grandfather. (From photographs furnished by Professor W. E. Castle of Harvard University)

he says, "black is dominant over white, rough coat over smooth coat, short coat over long coat."

By knowing these facts Dr. Castle is able to mate his guinea pigs in such wise as to secure precisely the kind of descendants he wishes them to have. They will be black or white, with long coat or with short coat, with rough coat or 
with smooth coat, with spots or bands or dashes of color, in exact accord with the ancestors he chooses for them. ${ }^{1}$

In all this discussion, remember that there are many hybrid mixtures of every kind of guinea pig, that hybrids are always more abundant than pure-breds, and that when men hunt for laws of inheritance, they are as careful as possible to start with pure-bred ancestors.

And because these laws of inheritance also affect human beings, we are interested in them. Science is teaching that each one of us is a bundle of combined characters. Shape of head, of hands, and feet; length of arm, of leg, and backbone; color of skin, of hair, of eyes; turn of nose and of jaw ; quality of brain-stuff ; type of temperament all these are combined in different ways in each generation, and some of the characters may be clearly traced back through generation after generation of our ancestors.

Speaking of this matter, Dr. Forel says : "In my own face the two halves are distinctly different, one resembling my maternal ancestor, and the other, in a lesser degree, my paternal ancestor; these points being seen distinctly in photographs taken in profile." ${ }^{2} \mathrm{He}$ adds: "A person may have his father's nose and his mother's eyes; his paternal grandmother's humor, and the maternal grandfather's intelligence, and all with infinite degrees of variation, for it is only a matter of more or less accentuated variations."

Much less is known of mental than of physical inheritance, nevertheless Dr. Forel shows how it may explain the children of many a distinguished man. He says that "a common woman will lower the level of the offspring of a

1 All this is called "breeding for points." Nothing of the kind has been done for human beings.

2 Doubtless an unusual case. 
distinguished husband, and inversely. . . . Moreover," as he adds, "the most deceptive point is the contrast of a man of genius with his children who do not rise to his standard because they represent a combination of ancestral energies with their other parent."

We shall return to this subject later in the book.

The next chapter goes back to the man who first discovered that color, shape, etc. are inherited through the working of definite laws. No name to-day ranks higher among students of biology than that of Gregor Mendel, the man who studied flowers for the sake of understanding inheritance. 


\section{CHAPTER IV}

\section{MENDEL AND HIS GARDEN PEAS}

Those who watched the man must have wondered what possessed him. Every day they saw him in the gardens of the cloister there in Brünn,

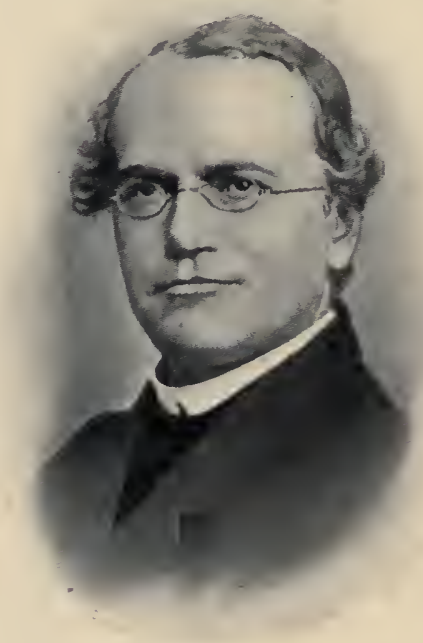

Gregor Johann Mendel Austria, and every day they noticed that, although he was a teacher of science, he worked like a trained gardener over his growing pea vines. Moreover, strange to say, he did not seem to care so much about the flowers on the vines as about the shape and the color of the seeds and the seed pods.

In the course of time the neighbors learned that the teacher's name was Mendel, ${ }^{1}$ and that altogether he had twenty-two different kinds of peas under cultivation. Probably they did not know that he was searching day and night for laws of

1 Gregor Johann Mendel was born in Heinzendorf, Austria, in 1822. He was always a faithful student, and became a priest in Brünn, Austria, in 1847. In 1868 he was appointed abbot of the Königskloster, where he had been priest. 
inheritance, and that he expected to find these laws just as surely by studying peas and their descendants as by studying animals and their descendants.

For the sake of getting clear results he studied characters in pairs or groups, as it were.

I. The form of the ripe seed — whether round and smooth or angular and deeply wrinkled.

2. The color of the cotyledon - whether yellow or green.

3. The color of the seed coat - whether white, gray, or brown.

4. The form of the ripe seed pod whether inflated and smooth or constricted between the peas and wrinkled.

5. The color of the unripe pod whether green or bright yellow.

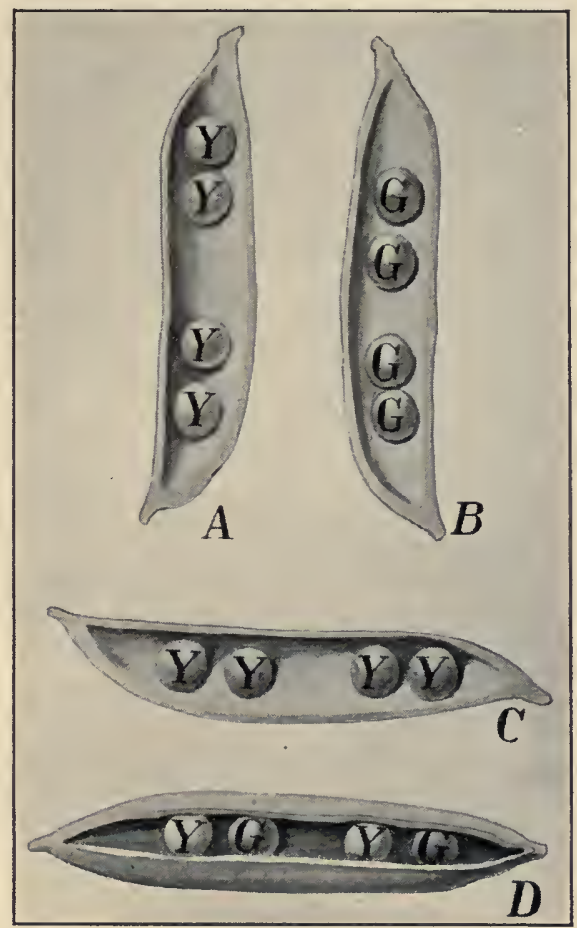

Color Inheritance in Peas

$A$, pod of yellow peas; $B$, pod of green peas; $C$, offspring of $A$ and $B ; D$, offspring of $C$. Notice that in $C$ yellow is dominant and green recessive, and that green appears again in $D$, just as white guinea pigs appear among the offspring of hybrid black guinea pigs. (From "Mendel's Principles of Heredity," by W. Bateson)

6. The way the flowers grew - whether they were bunched together at the top or scattered along on the stem. 
7. The height of the plant. One kind had a stem seven feet long, while the stem of another was but a foot long.

Mendel kept each kind absolutely separate from all the others; that is, he never let the pollen of one kind reach the stamens of another kind unless he himself put it there.

By being so careful he knew precisely which parents headed the list of each set of descendants. He could also tell which characters crowded the others out in the next generation. Those that dominated he called dominant; those that receded out of sight he called recessive. In fact, Mendel was the first man who ever used these words in this way, but they explain the case so well that nowadays we all use them. Here are some of the dominant and recessive characters of Mendel's peas in two separate columns.

Dominant

Tallness.

Round seeds.

Colored seed coats.

Yellow albumen in cotyledon. Purple flowers.
RECESSIVE

Dwarfness.

Wrinkled seeds.

White seed coats.

Green albumen in cotyledon.

White flowers.

Sometimes characters were neither dominant nor recessive, so that the next generation was of necessity a mixture.

Mendel kept on with his work of crossing pollen, watching results, and writing records until eight full years had passed. Then at last, in 1865 and again in I869, he reviewed what he had done, put his statistics together, came to his conclusions, and wrote them down for the benefit of other people. In these papers he told how he had developed new kinds of peas, why he had done it, and what laws of inheritance he believed he had discovered.

When he read his papers to the scientific society at Brünn, he himself was excited and enthusiastic, but he saw plainly 
enough that those who listened were neither excited nor enthusiastic. Indeed, they hardly seemed even interested, and when the reading was over, Mendel's own excitement was gone. His heart was heavy with disappointment. He had expected so much, yet nothing came of it. After that

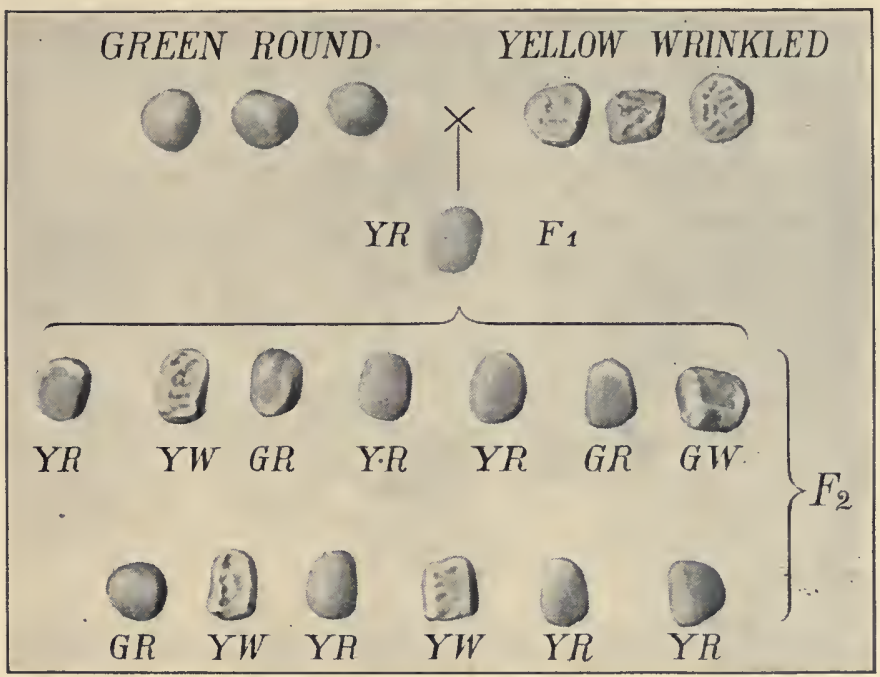

Inheritance of Seed Characters in Peas

$Y$, yellow ; $G$, green; $W$, wrinkled; $R$, round. Notice that when green round peas are fertilized by pollen from yellow wrinkled peas, the offspring (only one is shown) in the first filial generation $\left(F_{1}\right)$ are all yellow and round. This means that yellow and round are dominant, while green and wrinkled are recessive. Also notice that in the second filial generation $\left(F_{2}\right)$ the recessive green and wrinkled appear again in different combinations with the dominant characters. (From "Mendel's Principles of Heredity," by W. Bateson)

his papers were simply printed and packed away to gather dust in the Bruinn library. And there they stayed, out of sight and out of mind, unheard-of and undreamed-of, for thirty-four years. Fortunately, however, during all these years the library had them in safe keeping. 
Mendel himself died in 1884 , and it is reported that many times before he died he was heard to say, "Meine Zeit wird schon kommen" ("My time will yet come"). Then at last it did come for in 1900, sixteen years after he had been buried and apparently forgotten, his priceless papers were discovered by younger scientists, and news of the discovery was telegraphed to all parts of the.world.

To-day every book that discusses inheritance takes Mendel and his laws into account. Every breeder who studies inheritance in rats, rabbits, mice, guinea pigs, and men builds on foundations which Mendel laid over fifty years ago in his Austrian gardens. Every intelligent man who raises plants and animals for the market improves his stock according to laws which Mendel discovered.

Indeed, in these days the whole subject of inheritance is stamped with his name. We speak of "Mendel's laws of inheritance" and of "Mendelism," which means the same thing. The truth is, the laws given in the last two chapters are nothing but Mendel's laws as we see them working through families of fowls and guinea pigs.

Study the following statements carefully. Compare them with the diagram of Andalusian fowls, and see how well they go together.

\section{Mendel's Laws stated in Simple Terms}

I. When pure-breds are mated with other pure-breds like themselves, every one of their offspring will be pure-bred. Moreover, so long as pure-bred continues to mate with purebred, the descendants of every generation will continue to be pure-bred.

2. When a pure-bred of one kind is mated with a pure-bred of another kind, every member of the next generation is hybrid. 
3. When hybrids are mated with each other, half of their offspring will be hybrid, one quarter will be pure-bred like the father, the other quarter will be pure-bred like the mother.

These, then, are Mendel's great laws of inheritance. He discovered them by studying averages taken for multitudes of cases: They apply equally well to plants and to animals of every kind in every land. ${ }^{1}$

Mendel discovered his laws through the help of garden peas. Other scientists have proved them through the help of rats, rabbits, mice, guinea pigs, and other small animals. We ourselves should make use of them for the advantage of our own descendants.

1 In 1900, just before Mendel's work had béen discovered, these same laws of inheritance were rediscovered by three different students, who investigated independently in three different countries - De Vries in Holland, Correns in Germany, and Tschermak in Austria. 


\section{CHAPTER V}

\section{LAWS OF INHERITANCE PUT TO USE}

During the year 1900 the National Association of British and Irish Millers decided that the wheat yield of Great Britain was far too small - that a better grade must be grown, and

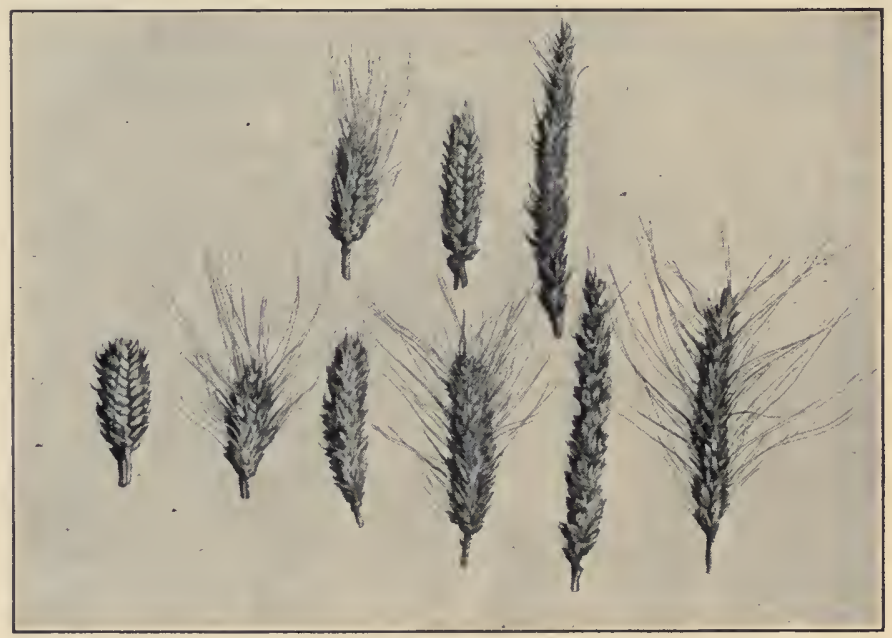

VARIETY IN HEADS OF WHEAT

The upper row shows two parents with their offspring between them. The second row shows six types that belong to the next generation of descendants. (Photographed from specimens supplied by Professor Biffen.) (From "Mendel's Principles of Heredity," by IV. Bateson)

that they themselves must have the benefit of this new wheat as promptly as possible. Accordingly they raised money and asked certain scientists to do what they could to produce the wheat for them. 
Professor R. H. Biffen, of Cambridge, England, was chosen as chief investigator. His first act was to get samples of wheat, each one of which had some especially fine quality. One bore grain on a stout stalk, another had a full head of wheat, another was beardless, another yielded a great amount of grain to the acre, still another could not be injured by the wheat disease called rust - that is, it was immune to this particular disease.

These and other varieties reached Dr. Biffen from different countries, and he kept them strictly apart except as he himself planted and paired them according to the descendants which he wished them to have. He did no guessing about his work; neither did he wait for haphazard results. He had studied the laws of inheritance, and he knew perfectly well that by selecting ancestors carefully enough, and by keeping cause and effect ever in mind, he could travel a straight road toward his desired end.

After a fashion he was really forcing a new variety of wheat into existence, and he was so successful that in the course of time he presented the National Association of Millers with precisely what they wished. This new wheat had a strong stalk and a full head of grain kernels. It was rich in gluten and beardless. It could resist all attacks of the dreaded rust, and it yielded large quantities of grain to the acre. Science had helped nature evolve a wheat which satisfied even the clamor of the millers. They pronounced it a great success.

And what of corn, that other food stand-by?

In the state of Washington, in 1912, two fields of corn grew side by side. Each covered ten acres; each grew in the same kind of soil ; but, strange to say, one of these fields yielded about half as much again as the other. I asked what made the difference, and the farmer who owned the rich field gave a broad smile. 
"Well," he said, "I simply took corn ancestors into account, and my neighbor over there did n't pay any attention to them."

"In what way ?" I asked.

"The only possible way," came the answer. "I was careful where the seed came from. Last year most of my corn had one ear to the stalk, just as his has now ; but I noticed that some of my stalks had two ears to the stalk. So you see, that was my clue. Those were the ones I saved for seed com." How he smiled!

"Besides that," he went on, "even when there were two ears to the stalk, I never kept seed that grew on weak stalks. All that corn of mine" - and he waved his hand triumphantly toward his ten acres - "came from seed that grew on strong stalks; each one of those stalks bore two ears apiece. And look at it now. More than half that corn has two ears to the stalk. Some of

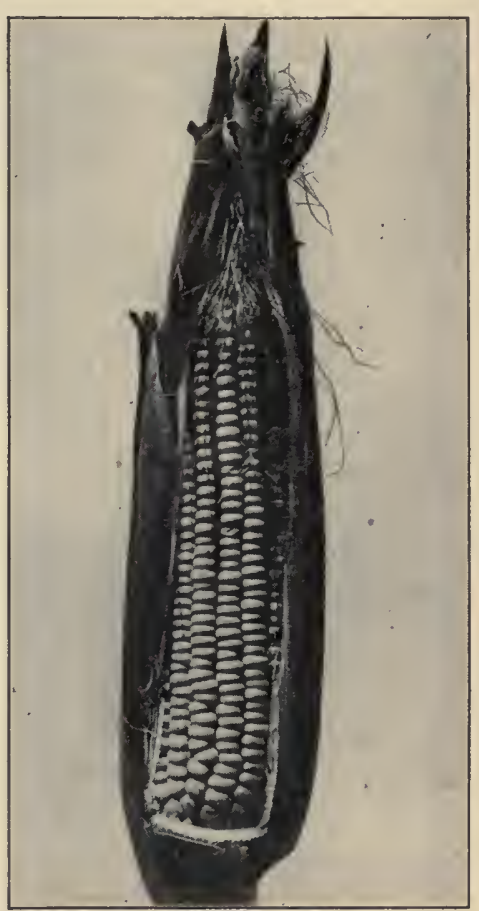

AN EAR OF CORN IN ITS HUSK it carries three ears. Good investment, wasn't it?" And he smiled again.

Had this farmer owned Luther Burbank's seed corn, he might have done better yet, for Mr. Burbank has raised corn that grows sixteen feet into the air and bears thirty-two ears 
to the stalk. He has also grown a potato so fine that the United States Department of Agriculture says it is "adding seventeen and a half million dollars a year to the farm incomes of America alone."

There is no question about wheat and corn and potatoes; man has changed them all for the better. And the list might be made many times longer, for nowadays the same laws of inheritance are being used to improve tomatoes, watermelons, apples, grapes, beans, peaches, and other edible things.

Then, too, there is the case of cotton to be rescued from the weevil.

In the southern states of America the boll weevil is the pest of the cotton crop. It is a flying insect that punctures the flower buds and the bolls of cotton and lays its eggs within. Here these eggs hatch out into small worms which feed on the heart of the bud. This so damages the growing flower that it loses its vitality and falls to the ground before the cotton is formed. At last, however, a variety of cotton plant has been developed which not only bears cotton that is long and silky, but which flowers so early in the season that the cotton itself is ready to be picked before the boll weevil has harmed it. This single discovery will save thousands of bales of cotton every year.

Laws of inheritance have certainly been pressed into practical use in all sorts of directions. And now steps in Luther Burbank to show what can be done in securing beauty.

He took the plant amaryllis, with its slender stem and its blossom two or three inches across, and from this he helped nature evolve a new amaryllis with low, sturdy trunk about eighteen inches high, and a blossom nearly a foot in diameter. He took the common, everyday poppy, multiplied its hybrids by tens of thousands, made careful selection of ancestors, kept 
close watch of descendants, continued the selecting, the rejecting, and the multiplying for several years, and to-day it is as if the flower had been glorified. Each blossom is from eight to ten inches in diameter. When one is placed above another in a column, seven of them will stand as high as a man. With a dozen of these blossoms in front of him, even

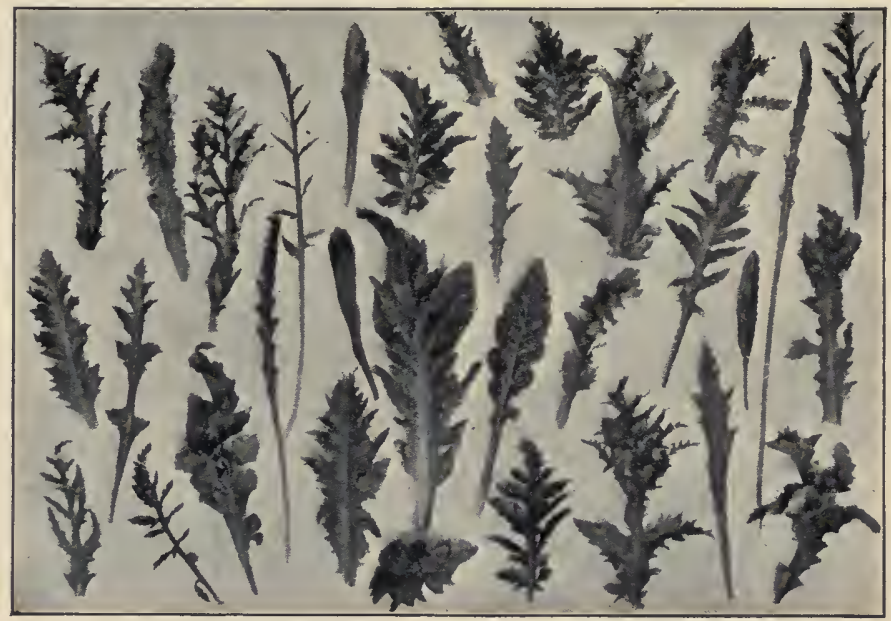

Variation of Hybrid Poppy Leaves

Out of two thousand plants no two were alike. (From "New Creations in Plant Life," by W. S. Harwood. Published by The Macmillan Company)

a large man would be hidden out of sight. Mr. Burbank is even able to take "a single one of these new poppy-seed capsules, divide it into four sections, and, by pollinating each section, produce from one section an annual plant, from another a perennial, from the third quarter crimson poppies, from the fourth, white ones." He has also produced a blue poppy, unknown to the world before, and has changed the color of the native poppy of California from gold to crimson. 
In addition he has transformed the plum and has made a combined fruit from the plum and the apricot. He has taken the old-fashioned wild daisy of New England, has combined it with daisies from Japan and England, and has secured the lovely Shasta daisy, which has no rival. He has taken the thorn-covered cactus of the deserts of the West, has removed the thorns for future generations, and has made the plant

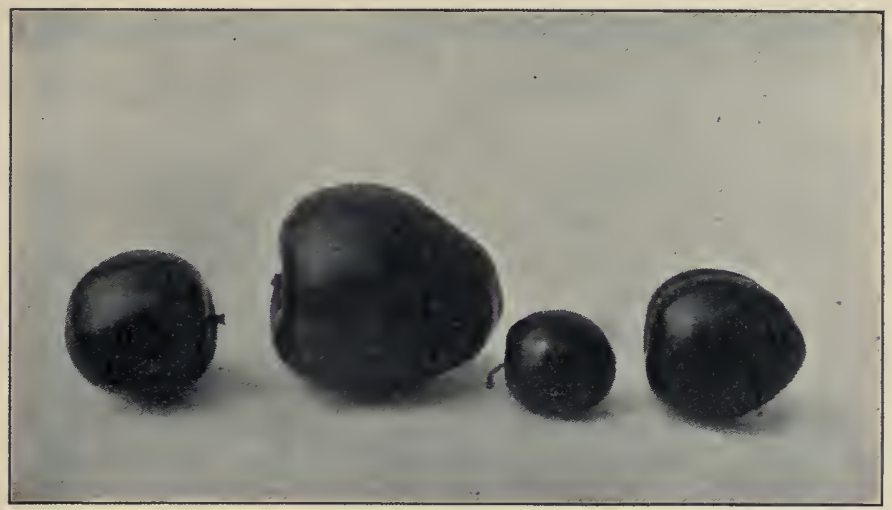

The Development of the Plum

The two larger ones are seedlings of the other two. (From "New Creations in

Plant Life," by W. S. Harwood. Published by The Macmillan Company)

useful to man and beast alike. No limit can be set to the value of this single transformation.

The list of what Mr. Burbank has helped nature to do might be made much longer. In each case, however, he merely did the guiding; nature did the work according to laws of its own. The same is true of changes brought about in animal life.

Take sheep, for example. Some are liked because they are hornless, some for the quality of mutton they supply, some for the long, soft wool they grow. Knowing what was 
desired, and knowing how to secure results through inheritance, certain breeders in England claim to have produced a final and best variety of sheep. Here all the wished-for characters have been so happily brought together that to-day breeders proudly show the result - a sheep which bears fine

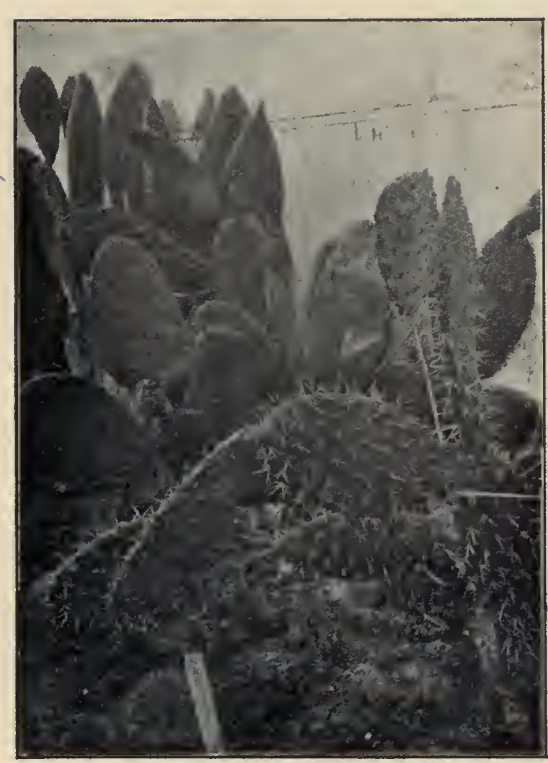

The Cactus

In the foreground is the ordinary thorny kind; those in the rear are the thornless ones of the same species, secured by Mr. Burbank. (From "New Creations in Plant Life," by W. S. Harwood. Published by The Macmillan Company) wool, is hornless, and yields the sort of mutton that meat-eaters like the best. Practical breeders have secured its evolution by controlling its ancestors.

We may take cattle for another example. Shorthorns have been developed in England during the past hundred and fifty years. They are profitable for their beef and sometimes for their milking qualities. Then there is the Jersey, famous for its rich cream. In I904, at the World's Fair in St. Louis, a Jersey cow took the prize. And no wonder, for within seven and a half months her cream yielded over 547 pounds of butter. Holstein cattle are bred for the quantity of milk they give; Hereford for the quality of their beef. Some are chosen for color, for shape, or for size; others for their combination of characters. 
Horses are bred not for quality of meat, not for texture of wool, but for the work they can do, for the speed they can make in running, for their shape, their color, and their - general good looks.

But all this is about modern changes in plants and animals. It is an account of forced evolution, as it were. It shows what takes place when man uses the laws of inheritance in this

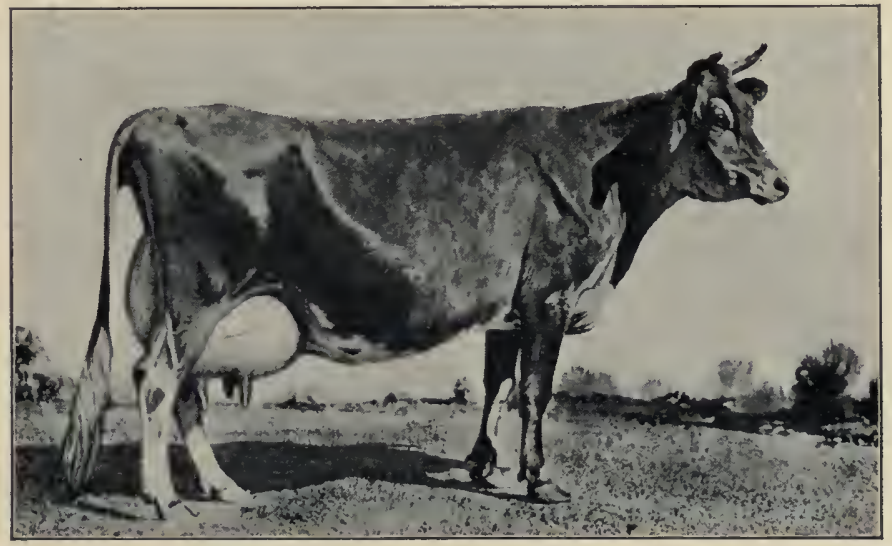

Jersey Cow, Figgis 76106

Property of C. I. Hood \& Company, Lowell, Massachusetts. Champion and Grand Champion, World's Fair, St. Louis, 1904. Made 547 pounds 6 ounces of butter in seven and a half months. Such a cow is worth perhaps a dozen of the ordinary kind that make 125 pounds in a year

direction or that, as he wishes to get something different in the next generation, and in the next, for indefinite periods of time.

As we know, the whole era of this modern experiment lies within the memory of the human race. There were, however, other eras and generations unnumbered, in ages before man began his reckoning, when evolution made the same resistless headway, yet moved at slower pace and without the aid of man. The horse best illustrates this prehistoric, slower evolution. 


\section{CHAPTER VI}

\section{EVOLUTION OF THE HORSE}

Hieroglyphics on ancient tombs show that, even so long as thirty-five hundred years ago, royal Egyptians went to war in chariots drawn by horses. Other records tell us that wherever man has gone since then in the development of civilization, he has taken the horse with him. To-day, therefore, we find this animal in all lands where man lives and can use him. And this use takes different forms. Horses are bred for strength, for speed, for gait, for looks, for size, for the ability to perform tricks, and for several other special purposes ; but no development of any sort changes them beyond recognition. By their looks, their acts, and their anatomy we decide without question that all modern horses are related to each other.

Bear these facts in mind as you go to the American Museum of Natural History in. New York City, and think about them as you visit what is called the Department of Vertebrate Paleontology. This is where many fossil bones ${ }^{1}$ are kept.

1 A fossil bone is one that has been gradually turned into stone during past ages. Little by little, through chemical action, mineral matter takes the place of the bone, and when the exchange is fully made, the bone itself has really become rock. Thousands of years are needed for the change, but, once made, the fossilized bone is brittle and heavy and able to endure as long as the rocks themselves shall lasst. It is to this bone petrifaction that scientists owe their knowledge of animals whose skeletons have been preserved unchanged for millions of years. 
When you reach the place, hunt for the horse bones. You will find them grouped together - skull bones here, leg bones there, jaw bones in a row by themselves. Each set is in its own glass case; each is carefully mounted and labeled; each is protected from meddlesome hands and from fire. Notice that all are arranged according to size, and that they show progress from smaller to larger.

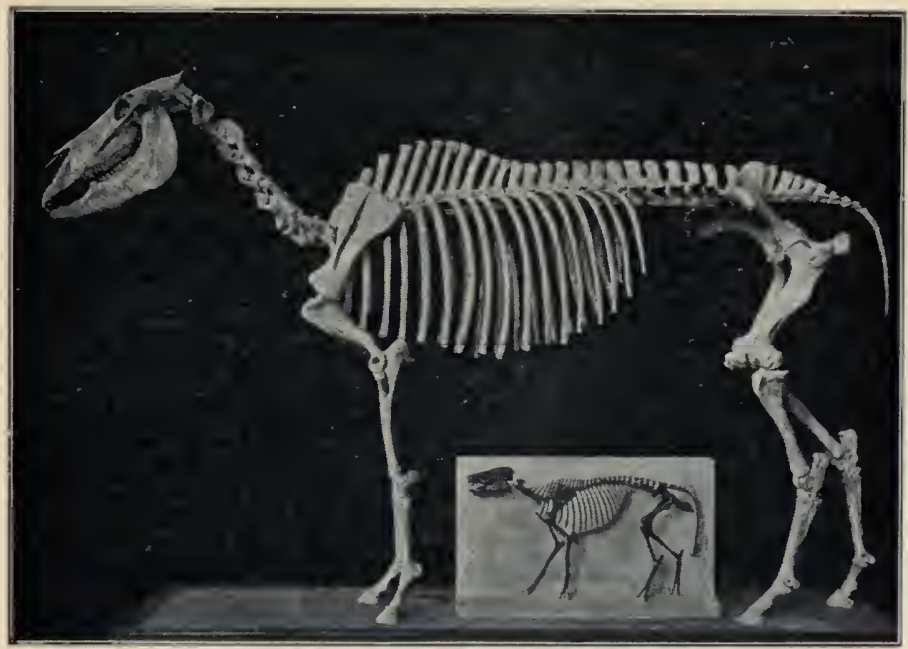

Courtesy of the American Museum of Natural History

HoRSE SKELETONS COMPARED

The larger skeleton is of a horse of modern times. The smaller one (set in plaster) is of a primitive horse that lived three million years or more ago. (After Osborn)

Give special attention to the skeletons - one sixteen inches high and about as large as a good-sized cat, another a giant that towers as high as the largest dray horse in a modern city.

If both these skeletons were wrapped in flesh again, if they were alive and could move about and meet each other to-day, neither creature would whinny to the other, for neither would recognize the other as a flesh-and-blood relation. 
Nevertheless, science tells us that thousands of other bones have been found, that these are graded all the way between the smaller and the larger skeleton, and that they prove the following remarkable fact: The huge dray horse is as truly related to the small, catlike creature as we ourselves are related to our own distant ancestors of prehistoric times.

To be sure, the smaller animal lived as much as three million years before his big relative was born, and it was during this time that legs and jaw and skull bones went through their tremendous transformations. The diagram shows what these transformations were.

Follow the foot as it changes into a hoof. Notice the middle toe. See it grow larger and larger, until the side toes are entirely crowded out of service. They do not so much as touch the ground. They hang in mid-air as the animal walks.

It took lengthened ages for nature to bring this change about. Then, in course of time, all but the middle toe had vanished from sight. Gradually also the toenail part of the middle toe had turned itself into a pounding hoof. And to-day, as Dr. Matthew ${ }^{1}$ says, "the horse may be said to be an animal that walks on its middle finger nail, all the other fingers having disappeared."

The nail itself has indeed become a hoof so broad and so strong that it is able to support the entire weight of the animal that travels through life upon it.

Examine the legs of any modern horse and you may find traces of two earlier toes. These so-called splint bones are four or five inches above the hoof, and they are so far out of sight and out of the way that they do not hinder the animal either in walking or in running. Neither do they in any wise help the horse as he walks and runs.

1 Author of "Evolution of the Horse." 


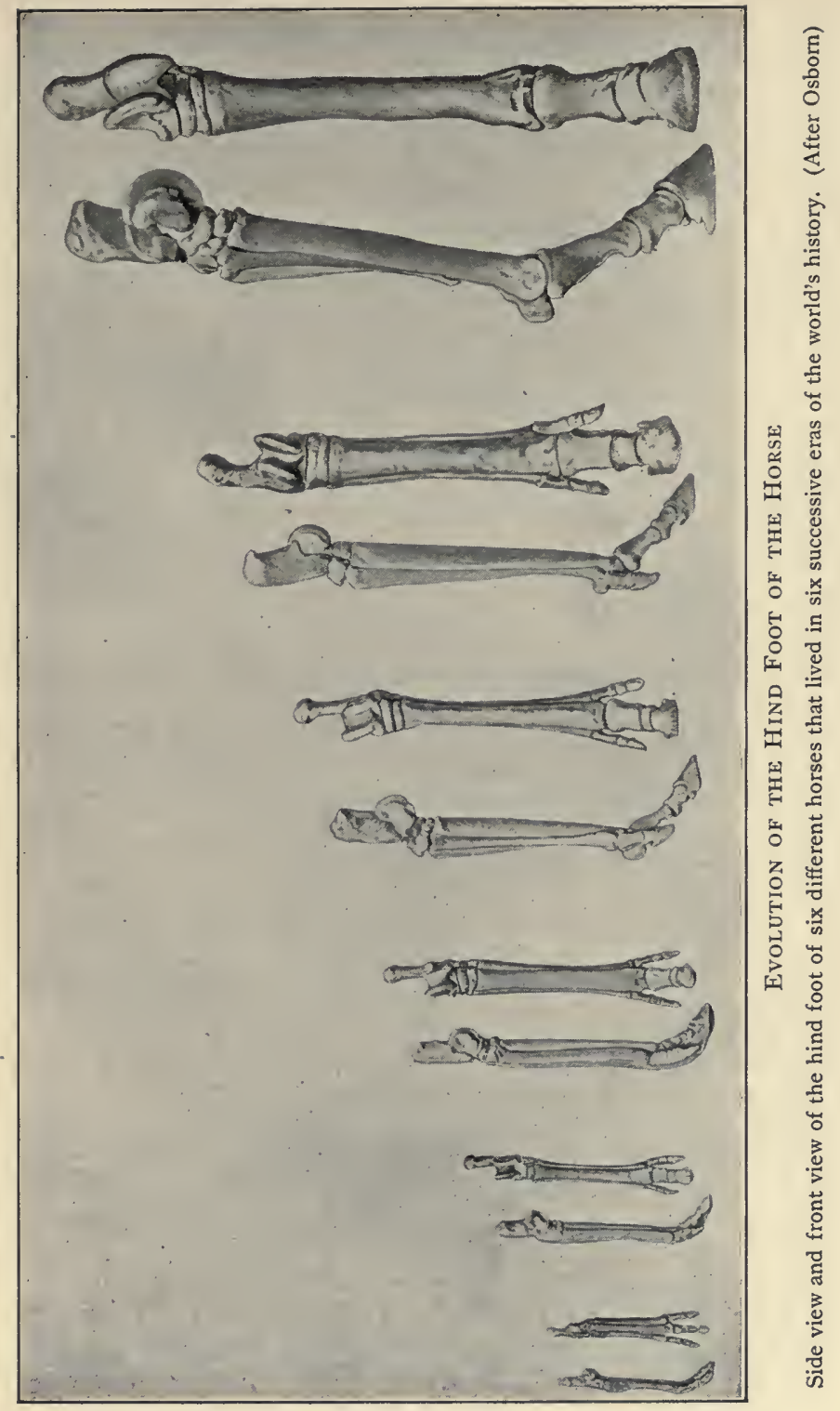


See by the diagram that while toe bones were changing in this way, jaw bones and teeth were changing, too. Notice that the small jaw of the smallest horse had teeth close together all the way from back to front. Now trace the change. See the jaws stretch out in front little by little from generation to generation.

Notice that even though the jaws grew longer, the number of the teeth stayed the same. Not a new one arrived to fill up the gap. The front teeth stayed in front, the rest stayed on the back of the jaw, a growing gap separated the two sets, and that gap grew wider and wider, until our own kind of horse appeared. And it is because this modern horse has several inches of stretched-out jaw which carry no teeth whatever, that a twentieth-century man can guide a twentiethcentury horse with bit and bridle.

When you find a friendly horse some day, examine his mouth and make discoveries for yourself. At the same time think of his ancestors and try to imagine what men thought when they first found fossil bones of that most ancient, smallest horse.

Dr. Matthew says that when its bones first came to light years ago, even students of such subjects did not so much as suspect that the little creature was a horse. Instead they called him Hyracotherium, meaning "the coneylike beast." But afterwards so many other bones were found in Nebraska, Arizona, Oregon, and elsewhere, that these same students were able to construct the bone pedigree of our modern. horse. At the same time they named the different types, as the chart shows.

They traced connections from smaller horse to larger, from four toes to one toe, from foot to hoof, from short jaw to long jaw, and as they did all this they saw that every bone, 
every tooth, and every part of the skeleton had been changed by slow degrees during unmeasured periods of past time.

Moreover, with this knowledge as their basis, they knew they had in hand a key which would help unlock the mystery of all change in all animals, both ancient and modern.

\begin{tabular}{|c|c|c|c|}
\hline Head & Fore Foot & HindFoot & Teeth \\
\hline 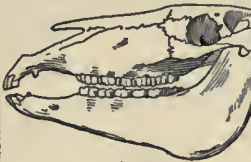 & $\int \begin{array}{c}\text { One Toe } \\
\text { Splints of } \\
\text { 2nd and 4th } \\
\text { digits }\end{array}$ & $\begin{array}{c}\text { One Toe } \\
\text { Splints of } \\
\text { 2nd and 4th } \\
\text { digits }\end{array}$ & \multirow{2}{*}{ U. } \\
\hline Protohippus & 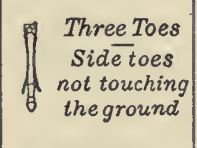 & $\begin{array}{c}\text { Three Toes } \\
\text { Side toes } \\
\text { not touching } \\
\text { the ground }\end{array}$ & \\
\hline$\sum_{\text {Mesohippus }}^{\sum_{0.03}}$ & $\begin{array}{c}\text { Three Toes } \\
\text { Side toes } \\
\text { touching the } \\
\text { ground; } \\
\text { Splint of Sthdigit }\end{array}$ & \multirow{2}{*}{$\begin{array}{c}\text { Three Toes } \\
\text { Side toes } \\
\text { touchingthe } \\
\text { ground }\end{array}$} & \multirow{3}{*}{$\begin{array}{l}\text { (8) } \\
\text { Short- } \\
\text { without } \\
\text { Cement }\end{array}$} \\
\hline $\begin{array}{c}\text { युक्तु } \\
\text { Protorohippus }\end{array}$ & Four Toes & & \\
\hline $\begin{array}{c}\text { Hyracotherium } \\
\text { (Eohippus) }\end{array}$ & $A_{1}^{\text {Four Toes }} \begin{array}{l}\text { Splint of } \\
\text { 1st digit }\end{array}$ & $\begin{array}{l}\text { Three Toes } \\
\text { Splint of } \\
\text { 5th digit }\end{array}$ & \\
\hline
\end{tabular}

Drawing of Skulls, Feet, and Teeth of Prehistoric Horses, GROUPED FOR COMPARISON

They show the development of the horse by evolution. (Reproduced, by permission, from "Origin and History of the Horse," by.H. F. Osborn)

As might be supposed, it takes two sets of scientists to make out the truth about buried bones.

I. There is the geologist. He studies the earth itself, knows which parts of it were formed first, which later, and by knowing just where the bones came from, he tells us which 
animals lived earlier, which later. He assures us that the smallest horse bones are the oldest horse bones ever found.

2. The paleontologist comes next. He puts fossil bones together and tells us what kind of creature each animal was. It is the paleontologist who describes horse bones in the museum. He lets us see for ourselves that they are linked together from generation to generation, and that they make up an unbroken chain of ancestors and descendants.

Other fossil bones tell tales of monster creatures that lived and changed-and vanished from the earth long before man appeared. Each separate one yields its own separate story, but no set of bones is easier to study, none gives quite such a straight-ahead history, as the bones of the horse.

These have been found in North and South America, in Europe, Asia, and Africa. Of all these places, however, Dr. Matthew says the best series comes from what is called the Tertiary Bad Lands of the Western United States.

As you bear these bones in mind, turn to the finest horse you know and think of his pedigree. Also observe his present size and shape, his powerful muscles, his long and slender legs, his neck just long enough to carry his mouth to the ground for grazing. Look at his strong, broad hoof (he is the only single-hoofed animal in the world) and try to realize that it was the ancestors of this horse that made him what he is to-day.

Many a man points proudly back to an ancestry more noble than himself. The horse might point backwards, too, not to show that once upon a time he had ancestors bigger, braver, more glorious than he himself is now, but simply to show that from small beginnings big results have come - to make it plain that, quite without conscious purpose, his early ancestors improved their opportunities, adjusted themselves to 




Courtesy of the American Museum of Natural History

Comparative Size of the Ancient and the Modern Horse

The upper figure shows the skull of a large modern horse. The lower figure shows a prehistoric five-toed horse restored and placed here for comparison. (After Osborn) 
circumstances, and thereby so influenced their descendants that each generation passed a better inheritance on to the next.

To-day if horses had the brain power of man, if they could study the past and talk about it as man is apt to do, each would have the right to say, "Through the struggle of my ancestors I am what I am."

Since the laws of inheritance do not affect the horse alone, since they mold all other animals (including man), since they cover generations of time that sweep back beyond the reach of our reckoning, we understand why it is that scientists study the subject from year to year with an interest that never flags. They are determined to find out all they can about the laws which control and gradually change living beings as the ages go by.

No one has spoken more clearly on this subject than Charles Darwin. For this reason the next chapter will give some of his facts. 


\section{CHAPTER VII}

\section{A FEW OF DARWIN'S FACTS}

Night after night Charles Darwin, already an aged man and famous, watched the actions of his angleworms. He kept them in his study in flowerpots, for he wished to find out for himself how much mental power they had. He knew they could not see, for they had no eyes ; that they could not hear, for they had no ears ; that they could feel, for he had seen them shrink from the touch of any sharp thing. But the question was, Did they think as well as feel? Did they guide their actions consciously? This Charles Darwin wished to know.

It happens that

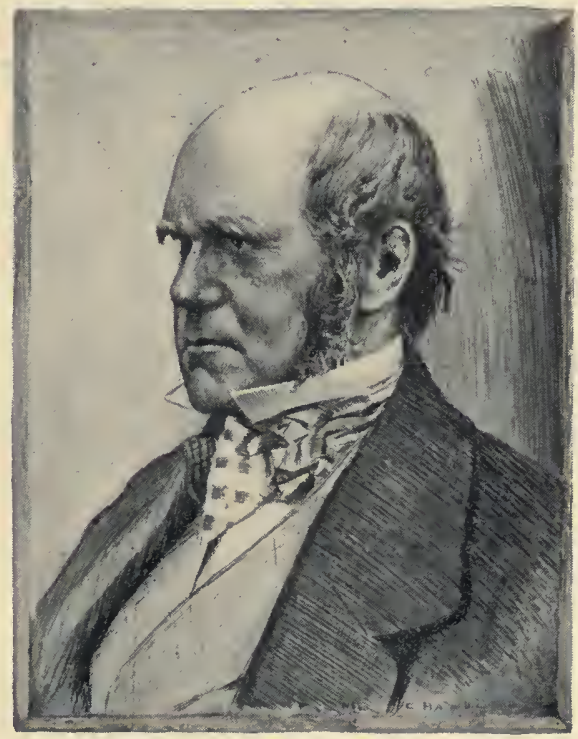

Charles Darwin angleworms can only be studied at night, because by daylight they hide themselves underground, out of sight, but at night they stretch themselves out of their burrows and face the 
world and run the risk of being captured. By night, therefore, Darwin not only watched their operation in his flowerpots, but he also took his lantern and went into the fields to find them. Sometimes they raised themselves on their tapering, bent-over ends and seemed to be giving strict attention; sometimes they shrank back into their burrows as if the light on their bodies gave unpleasant sensations. Darwin watched them as they seized leaves and drew them down to stop up

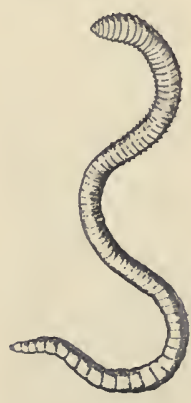

AN ANGLeWORM the mouths of their burrows. He saw how they saved their lives and lost them; how they did their burrowing; how they gathered food and used it ; how they survived the winter rolled up in balls underground.

For years the study went on, and no doubt it had really begun years earlier, when Darwin went a-fishing as a boy, for he writes: "I had a strong taste for angling, and would sit for any number of hours on the bank of a river or pond watching the float. I was told that I could kill worms with salt and water, and from that day I never spitted a live worm, though at the expense, probably, of some loss of success."

This, then, is our introduction to the boy who was to become one of the world's most famous naturalists - the man who was to change certain beliefs of men for all future generations. No student of inheritance consents to be ignorant about Darwin.

The work of his life lies between the time when, as a boy, he salted angleworms to save them from pain on his fishhook by day, and when, as an aged man, he studied angleworms by night for knowledge of their habits. It also appears that from the beginning of his life until it ended, Darwin's work knit itself together as two parts. 
I. He gathered facts.

2. He drew conclusions from his facts.

Even before he was eight years old he collected shells and compared them with each other. Next he began beetle collecting. He was now a university student in Cambridge, England, and wherever he went in his walks, he was ready to see beetles and to seize them. This brought him to grief one day, for, as he says, "on tearing off some old bark, I saw two rare beetles, and seized one in each hand; then I saw a third and new kind, which I could not bear to lose, so I popped the one which I held in my right hand into my mouth. Alas, it ejected some intensely acrid fluid, which burnt my tongue. so that I was forced to spit the beetle out, which was lost, as was the third one."

And this is but a sample of Darwin's enthusiasm from youth to old age; he never lost it. On every side he gathered facts, and when he had facts enough, he began to draw conclusions. No doubt his largest field for facts was South America. When he was twenty-two years old, he was asked to go as naturalist on board the Beagle. ${ }^{1}$ He accepted the invitation; spent five years in sailing from one country to another ; made collections everywhere; and when he reached home again in 1836 , he was laden with treasures and with the memory of his experiences.

While in South America he came upon unnumbered fossil bones of buried monsters - creatures that had lived there and

1 The Beagle was a sailing craft that weighed 235 tons. It was sent out on a voyage of scientific investigation by the English government, and Darwin went as naturalist for the expedition. As he himself states it, "The real object of the expedition was to complete the survey of Patagonia and Tierra del Fuego, to survey the shores of Chile, Peru, and some islands of the Pacific, and to carry a chain of chronometrical measurements around the world." 
had died there before man had so much as appeared on the scene. He found head bones of some, leg bones of others, numberless huge teeth, and a few skeletons that were complete in every detail.

Darwin named one of these the toxodon. He said it was as large as an elephant, and one of the strangest animals ever discovered. By its teeth he knew it had gnawed its food, just as rats and rabbits also gnaw when they eat; and from

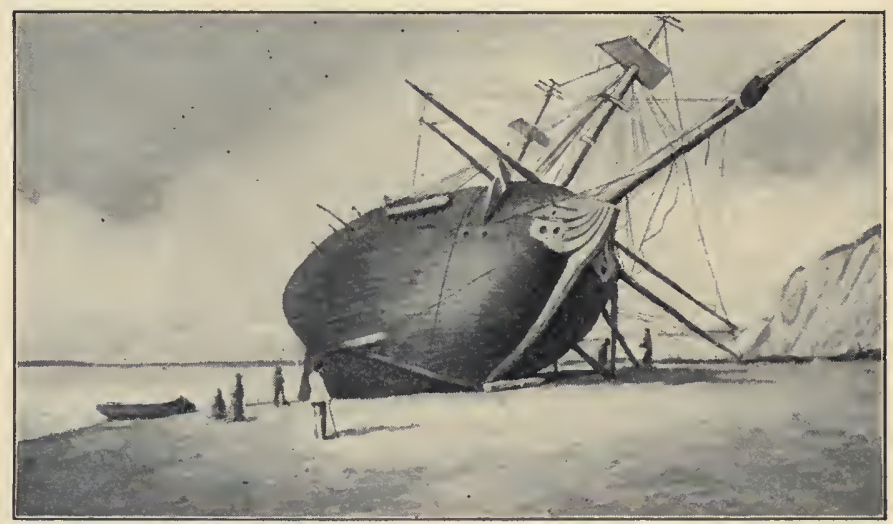

THE BEAGLE LAID ASHORE FOR REPAIRS

the position of its eyes and ears and nose he knew it was an animal that lived in the water. In one place he came upon what he calls "a perfect catacomb of monsters of extinct races."

Keep the giants themselves in mind, then note these facts: Within the memory of man no such creatures have been alive in South America; all were extinct and turned to fossils when man first found himself in the land which had belonged to those earlier huge inhabitants. So true is this that in South America to-day the only wild living creatures are 
comparatively small - the tapir, the deer, the monkey, etc. Darwin says that ten. specimens of the largest kinds weigh an average of but 250 pounds apiece. It is interesting to compare the size of these animals with the size of those in South Africa. There the elephant, the hippopotamus, the giraffe, eland, rhinoceros, and others are so large that ten members of the large kinds of animals weigh an average of 6040 pounds apiece.

The strange fact about all this is that ages ago South American animals were quite as large as the present-day monsters of South Africa. Darwin says that at the very time when the animals of South America were becoming extinct, those of South Africa stayed alive through their descendants.

Another set of Darwin's facts had to do with the horse. History tells us that when Columbus and his Spaniards came to America, not a horse was to be found in the land. They were, in fact, so unknown and unheard-of that when, years afterwards, a few were brought over from Europe, the native Indians looked at them with curiosity and fright. Imagine, then, the surprise of Darwin and other naturalists when they found fossil horse bones in different places from the northern extremity of North America to the southern extremity of South America. Clearly enough, horses were among the oldest inhabitants of the land; yet, quite as clearly, not one had survived to receive Columbus. All had died and vanished from sight long before man arrived in modern times.

Now it is interesting to know that while the largest early animals were dying off in South America they were also meeting the same fate everywhere else in the world except in Africa. The following statements bear on this point.

I. Fossil remains which have been found in Europe, Asia, North America, and South America prove that ages ago 
animals of the same general kinds were alive in all three continents during the same era of the world's history.

2. The theory which explains this is that in early times there was land connection between Siberia and North America, and that the joining place was where Bering's Strait now separates the two continents.

It is supposed that in those days this land connection was a well-traveled road, across which animals of every sort and size came as immigrants from the Old World to the New. "It seems most probable," writes Darwin, "that the North American elephants, mastodons, horses, and the hollow-horned ruminants migrated on land since submerged near Behring's Straits, from Siberia into North America, and thence on land since submerged in the West Indies, into South America, where for a time they mingled with the forms characteristic of that southern continent, and have since become extinct."

From first to last, Darwin was searching for facts which might connect one set of living creatures with all others. $\mathrm{He}$ wished, if possible, to relate the life of the past - even its monsters - to the life of the present. More than this, he wished to relate the life of the present to the life of the future. He hoped to find laws which would make it easier to understand why there are such countless varieties of living creatures on the earth to-day, and what their exact relation to each other is. In other words, the reason why Darwin gathered facts was because he was determined to find out as much as possible about the progress of life on the earth from generation to generation, through the ages of the past.

This was the burden of his ambition, and facts were piling up as the Beagle continued its voyage to the Galápagos Islands. 


\section{CHAPTER, VIII \\ DARWIN'S PROBLEM}

The Galápagos Islands lie on the equator, six hundred miles from the western coast of South America.

There are ten islands in the group, and here Darwin found animals unheard-of elsewhere in the world - tortoises by the

$$
\text { Culpepper } I \text {. }
$$

60 Miles

\section{WenmanI.}

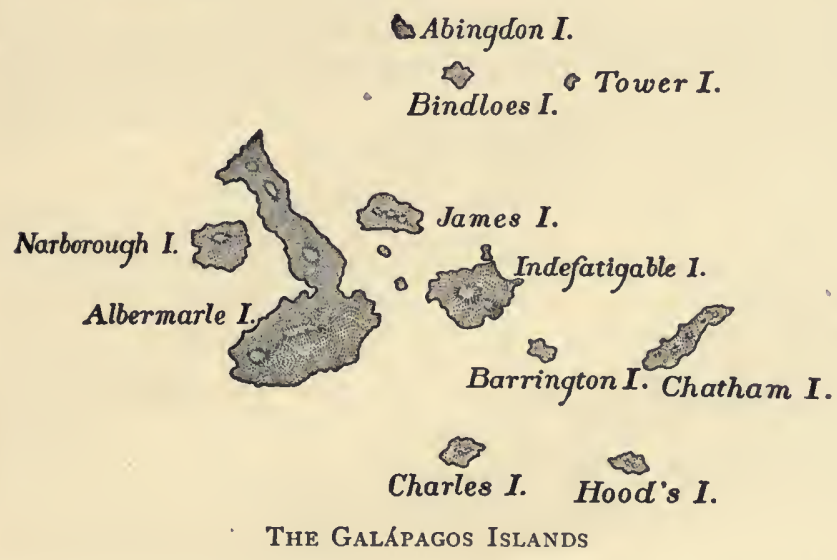

thousand, that weighed one hundred pounds apiece and over. "I frequently got on their backs," he writes, "and then giving a few raps on the hinder part of their shells, they would rise up and walk away; but I found it very difficult to keep 
my balance." Here were lizards two and three feet long, one "terrestrial," the other "aquatic" - - "the latter," says Darwin, "a hideous looking creature of a dirty black color, stupid and sluggish in its movements." Sometimes these lizards weighed twenty pounds apiece or more. They went off on swimming parties a hundred yards from shore. As a certain sea captain said, "They go to sea in herds a-fishing, and sun themselves on the rocks, and may be called alligators in miniature."

In this surprising place Darwin found and named new species ${ }^{1}$ of plants and animals by the dozen and the hundred. On every side he saw new birds, new reptiles, new shells, new insects; and yet, as he himself says, "by innumerable trifling details of structure, and even by the tones of voice and plumage of the birds," these various creatures reminded him of those other creatures, similar yet so different, that had lived on the "temperate plains of Patagonia or the hot, dry deserts of northern Chile. . . . What is the explanation?" he asks. "Why.were they created on American types of organization?"

1 A species is a group of plants or animals in which the individuals are very much alike.. For example, one species of violet has white blossoms, another has blue blossoms; one has round leaves, another has leaves of lancet shape. Each is a different species, but all are violets. Then there are the humming birds. One species is almost as large as an English sparrow, other species are no larger than huge butterflies. One species has bright feathers on its neck that give it the name nubythroat, another has half a dozen stiff red-feathers that stand above the others on its throat. All these are humming birds, but each is a different species. All other animals and plants are divided into species in the same way. Scientists do this for the sake of studying the life of the earth. They also put different species together to make a larger group, called a genus. They put genera together to make a family, and families together to make an order. Then come classes, divisions, and finally the animal and vegetable. kingdoms. 
He had gone no farther than this with his questions when the Beagle returned to England in 1836.1 And now began a new epoch in his life. He had his collection of fossils from South America. He also had his collection of modern skeletons from the same country, from the Galápagos Islands, from England itself; and he wished to find some laws of life which would explain the differences between them, and which would, at the same time, show that all forms of life are connected.

He asked himself whether or not the earlier kinds became extinct before the later ones were created; why they became extinct; why present-day creatures on the Galápagos Islands are more like the buried giants of South America than like modern animals in Africa; why there are so many species of different plants and animals in the world, etc. The list of his questions was very long when he reached England, and he saw that he must have still more facts before he could even try to draw conclusions.

To get these facts he turned his attention to pigeons, comparing them with each other. Among them he found the Carrier pigeon, with its large nostrils, its wide mouth, its lengthened eyelids, its long, steady flight over land and water; also the: Tumbler, with its way of flying high up and tumbling down, heels over head, at unexpected moments. Then there was the Pouter, with its stretched-out body, wings, and legs, and its enormous crop, which it proudly inflates to prodigious size; the Jacobin, with feathers that grow

1 During this voyage the Beagle visited the following places, in the order in which they are mentioned: Cape de Verde Islands, St. Paul's Rocks, Fernando, Noronha, South America, Galápagos Islands, Falkland Islands, Tierra del Fuego, Tahiti, New Zealand, Australia, Tasmania, Helena, Ascension. The Beagle did not go around the world, as at first intended. 
backward down the back of the neck and stand up like a hood; and, as conspicuous as any, the Fantail, with so many feathers in its tail (thirty or forty instead of twelve or fourteen) that it hardly looks like a pigeon at all.

Darwin studied each kind, and he came to the conclusion that each had been secured through man's careful selection

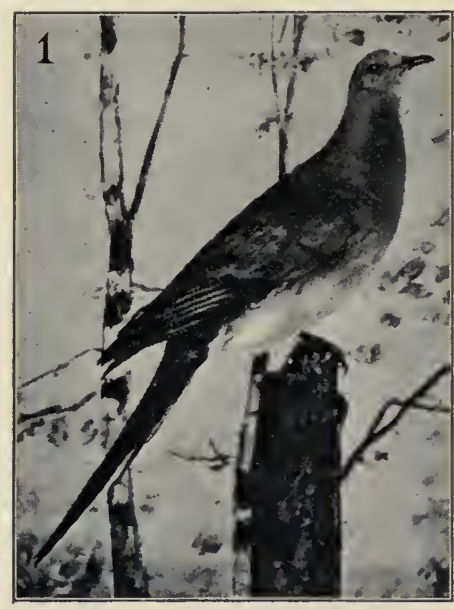

The Wild Parent of All the Domesticated Pigeons that have BEen DeVeloped by Selection

(From "Domesticated Animals and Plants," by E. Davenport) of pigeon ancestors - that not one had been created precisely as he himself found it. He even went so far as to say he was sure "that the common opinion of naturalists is correct, namely, that all have descended from the Rock pigeon. . . . At least a score of pigeons might be chosen," he said, "which, if shown to an ornithologist and he was told that they were wild birds, would certainly, I think, be ranked by him as well-defined species."

He talked the matter over with every intelligent bird breeder whom he met, and each assured him that the one essential thing was to select ancestors according to what was wanted in the next generation. All acknowledged that the process took time. One told Darwin that "he could produce any given feather in three years, but that it would take six years to produce head and neck." In every case this selecting was done by the breeder himself. He knew precisely what he wanted. 
The same was true of sheep breeders, and Darwin talked with them too. "In Saxony," he says, "the importance of

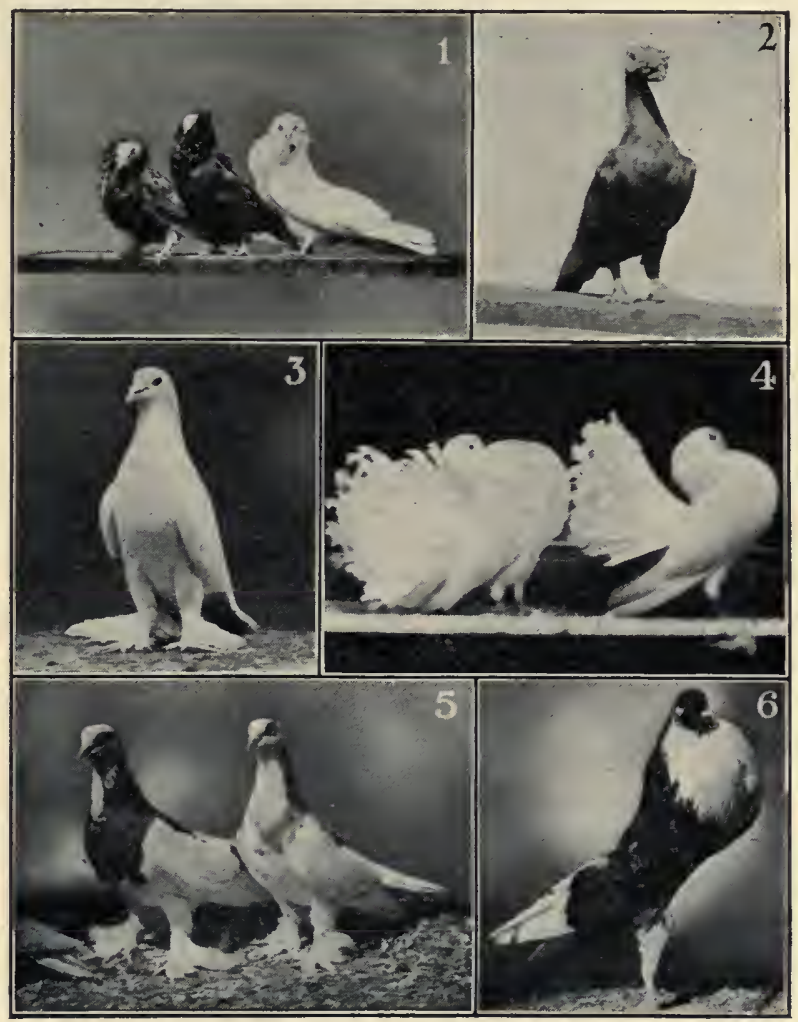

Types of Pigeon developed by Selection and Breeding I, Jacobins ; 2, English Carrier ; 3, Duchess ; 4, Fantails ; 5, Birmingham Tumblers; 6, English Pouter. (From "Domesticated Animals and Plants," by E. Davenport)

the principle of selection in regard to merino sheep is so fully recognized that men follow it as a trade; the sheep are placed on the table and are studied like a picture by the 
connoisseur ; this is done three times, at intervals of months, and the sheep are each time marked and classed, so that the very best may ultimately be selected for breeding. . . . And," he continues, "not one man in a thousand has accuracy of eye and judgment sufficient to become a good breeder." Lord Sommerville speaks of their success: "It would seem as if they had marked out upon a wall a form perfect in itself, and then had given it existence."

Do not forget that all this was before even the best breeders had heard of Mendel's laws and before Darwin himself had come to any conclusion about the power that controls the changing forms of life. Remember that even before Mendel and Darwin lived, breeders knew the following facts :

I. By choosing ancestors they could get the desired type of descendants.

2. Only by preventing cross mating could these new types be preserved.

Darwin saw how easy it is to explain the beginning of any species when man is behind, controlling ancestors. But he wished to know how it comes about that wild animals have changed, too. He wondered if there might not be other laws which control descendants even when man has nothing to do with choosing ancestors for them. He believed there are such laws, and he hoped to find them.

Darwin puzzled himself with this problem for twenty-three years, and at last he did what he could to answer it, in his book "On the Origin of Species by means of Natural Selection."

The volume itself was published in I 859. Twelve hundred and fifty copies were printed for the first edition, and every one was sold on the day of publication. Three thousand more were printed. These went fast, too, and by 1876 sixteen 
thousand copies of the book had been printed and sold. It was translated into every European language and was discussed by scientific papers in every scientific center of the world. It was a topic of talk for individual scientists as they met on the street, in the lecture hall, in the drawing-room, and everywhere else. Indeed, the excitement was so great that college students talked about the book in club and classroom. They sat up late at night in mighty discussion over Darwin's problem and over his solution of it. Certain merchants and preachers took up the subject and waxed eloquent about it over the counter and from the pulpit. And, as might have been expected, in every case those who knew most about the facts of life were usually most inclined to accept Darwin's theory about the origin of species. At the same time also, then as now, numberless persons lived in ignorance of Darwin's book and of what it taught.

Until he died, in 1882 , Darwin continued to gather facts, to draw conclusions, and to write about them for the benefit of those who were younger and more ignorant than he was. When he died he was seventy-five years old, honored and loved by thinkers the world over. His fame came through the success he had in studying certain problems of life, for his theory of evolution had turned upside down some of the cherished beliefs of the centuries. It was he who joined facts together in what we shall call the "five-linked chain." 


\section{CHAPTER IX}

\section{FIVE LINKS TO THE CHAIN \\ I. The Prodigality of Nature}

At ten o'clock this morning I sat on the veranda and watched flying objects that traveled through the air ready for planting and for growing. Dandelion seeds, by scores and by

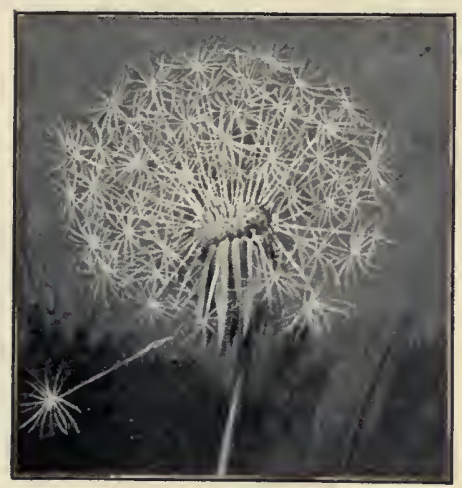

DANDELION SEEDS READY FOR FLIGHT hundreds, sailed across my vision like small parachutes bearing a precious burden. Maple seeds, thousands upon thousands of them, whirred by in zigzag fashion, steered without hands, guided by their delicate paddle rudders. They too bore their treasure of life and were ready for growing. Elm-tree seeds by the hundred thousand showered down like brown snowflakes in the sunshine, and rolled over each other as if in a panic of haste to find a lodging place for the elm trees of the next generation. ${ }^{1}$

As I watched all this I thought about the wasteful extravagance of nature. At the same time I stepped out to do some counting. Within one square inch of space I found twenty-five

1 These different kinds of seeds are not all in their prime at the same time, but in Ohio their seasons overlap each other. 
elm seeds crowded together in a heap. Near by, in another heap, on another inch of ground, were fifteen maple seeds piled upon each other, and there were many square yards

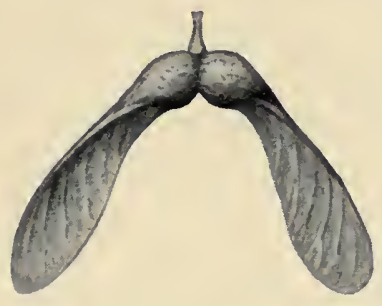

Maple Seeds of surface almost as thickly covered. One dainty dandelion stalk carried one hundred and fifty-four tiny parachutes in full sail, ready to fly off when the next carrier breeze came that way.

All this was on my own lawn one bright spring morning. I then thought of the wooded groves just outside of town. I remembered the trees, the shrubs, the weeds, and the wild flowers - some in full bloom, others already gone to seed. I knew that millions of seeds were under the trees and on the shrubs in every forest during every spring season. I also knew that no more than tens or hundreds of these seeds ever take root and grow.

I thought of the rivers too, and of the lakes, the ponds, and the ocean, with their millions of fish eggs laid in every breeding spot - multitudes never to be hatched, other multitudes to be devoured by bigger fish as soon as hatched, and very few to live long enough to pass life on to the next generation. "Prodigality, prodigality, on every side!" was my exclamation.

Next I turned to printed records and looked for added facts of the same sort.

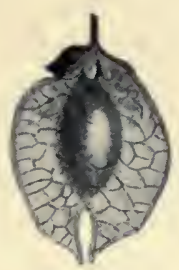

Elm Seed

Dr. Thompson says that a cod is reported to have two. million eggs, and that "if these all developed into cods, there would soon be no more fishing." This means that the ocean would be so full of swarming, struggling, dying cod, that 
immigrants and emigrants alike would be able to walk across a slippery cod pathway between Europe and America.

Dr. Thompson also says that "if all the progeny of one oyster survived and multiplied, its great-great-grandchildren would number sixty-six with thirty-three noughts after it $(66,000,000,000,000,000,000,000,000,000,000,000)$, and the heap of shells would be eight times the size of the world."

No human mind can grasp such figures as these. They are indeed extreme examples of the first law of Darwin's famous five-linked chain.

\section{The Struggle for Existence}

The second law follows as a matter of course. Indeed, there is no escaping it, for with creatures of every kind multiplying at this rate, - with each of them obliged to find food or die, - the competition grows terrific. It becomes a struggle merely to keep alive. This, then, is the second link of Darwin's chain.

It seems a peaceful world as I glance out of my window at the present moment. But, without seeing it done, I know that all forms of life are struggling not merely for food but for very existence too. Large insects are living on those that are smaller; small birds are living on large insects; birds are killing worms; cats are killing birds; dogs are killing rabbits; man is killing and eating birds and beasts of many different kinds; microbes are killing millions of creatures both large and small ; and man is killing microbes.

The slaughter is universal; the conflict is colossal. It continues on every side every day, and it is inevitable. For if the supply of plants and animals were not.limited in some way, - if all eggs were allowed to hatch and if all young animals lived on to good old age, - there would soon be such a battle 
on the earth as has never been dreamed of heretofore. Swarming millions of creatures would, within a few days, crowd out of sight even the standing space of the earth. Soon afterward the food supply of the world would be used up, and starvation would face all save those who found it possible to support their own lives by taking other lives.

This is no fancy picture. It would be the inevitable state of things if the prodigality of nature were not checked somehow. Fortunately there are checks on every side. Wind and weather, flood and fire, take part in limiting the numbers of those that are to survive for a next generation. For the struggle is not simply between the individuals themselves but also between each individual and its surroundings. Clearly enough, then, the maimed, the weak, and the inefficient generally have the poorest chance to live and become ancestors. And it is just because they do not live long enough to become ancestors that the race escapes deterioration. On every side they are crowded out in the struggle.

\section{VARIATION}

This fact brings us face to face with the third link in Darwin's chain. He noticed that while some animals of a species are large, others of the same species are small; where some are strong, others are weak; where some have keen intelligence, others are slow of understanding. He saw that always and everywhere, among all kinds of plants and animals, there are contrasts, differences, and variations. On this fact he based what he called the law of variation. It is the third link in Darwin's chain. Follow it now somewhat in detail.

When rain was withheld for some months in South America, Darwin saw thousands of animals die for lack of water; yet there is such variety in the power of animals to endure 
thirst, that some did not die. When food failed for birds in snow-covered Ohio during the winter of I9I 3 , farmers found many of them dead in the frozen fields; yet there is such difference in the power of birds to endure hunger for longer or shorter periods, and such variety in their ability to hunt for food, that many of them did not die.

In 1885 , when typhoid microbes found their way into the water supply of Plymouth, Pennsylvania, I IOO men, women, and children had the fever and were threatened with death; but there is such a difference in the power of individuals to resist disease that, although I I 4 persons died, 986 of those who were ill did not die, and hundreds of others who had used the same contaminated water were not even affected by it. ${ }^{1}$

When seven men offered themselves for the yellow-fever tests in Cuba in I900, all were bitten by mosquitoes loaded with blood from yellow-fever victims. But even against this disease there is a difference in the power of the body to protect itself. One man escaped with no touch of the fever whatever, six were ill with it, and one man died. ${ }^{2}$

Many other cases might be cited of persons who, overtaken by calamity, have escaped death because they had some power of endurance which those who died lacked.

\section{Survival of the Fittest ${ }^{3}$}

We are now within sight of the fourth link of Darwin's chain. He says that, because of the universal law of variation,

1 Described in "Town and City," of the Gulick Hygiene Series, p. 107.

2 Described in "Town and City," pp. 234-235.

${ }^{3}$ Darwin first called this the law of natural selection, meaning that the selecting was done without man's help; but some people misunderstood his meaning, so he adopted the phrase survival of the fittest, which Herbert Spencer used. It means precisely the same thing as natural selection, is easy to understand, and is the term in common use to-day. 
some members of each species are different enough from the others to survive in spite of threatened destruction. In other words, he tells us that it is the fit who survive. This, then, is the fourth link to the growing chain.

See how this law works itself out. Some creatures have longer legs and are therefore better fitted than their mates to run away when danger threatens. Some have stronger claws with which to kill the foe before being killed themselves. Some have keener eyesight with which to discover danger or to sight it from a distance and to escape it. Some have keener scent with which to trace both food and danger. Some can live longer than others when deprived of water. Some can survive a famine where others die in the midst of it.

Thus, in one way and another, in every group of animals, when the critical moment comes, certain individuals are better fitted to survive than are their neighbors. This does on no account mean that the fittest are always the largest, the tallest, the keenest-eyed, the bravest, the strongest, or the longest-legged. Certainly not. The huge animals of South America were bigger than any of those that crowded them out; English sparrows of the United States are smaller than bluebirds, swallows, robins, the purple martin, and other birds that please us; but the smaller sparrow attacks the larger birds, takes up their nesting places, destroys their eggs, and finally succeeds in driving them from our villages.

During heavy storms it is the birds with small bodies and strong legs and wings that survive, while birds with large bodies and small wings die in greatest numbers.

Judging by appearance, certain animals - the donkey, for example - were better fitted to survive when their ears were large. It was different with moles. Living and working underground as they did, ears were a nuisance; they got in 
the way. For this reason those with the smallest ears were best fitted to survive, and now we have the modern mole with ears so small that they are not worthy of mention. The change has come about gradually, step by step, through the laws of variation, the struggle for existence, and the survival of the fittest. Nevertheless, none of these laws would be of the slightest value from one generation to the next without that supreme law which forms the fifth and final link to Darwin's chain.

\section{Heredity}

The mere mention of this word carries us back to the first chapters of the book. It calls to mind Andalusian fowls and guinea pigs. It reminds us of all that inheritance does for the next generation and the next, when man selects ancestors and decides to bring about definite changes in animal descendants. But remember that Darwin was searching for laws which control the destiny of all descendants, whether their ancestors are selected by man or not.

No human power ever chose the ancestors of the wild animals of to-day. Nevertheless, Darwin believed that these same ancestors were selected relentlessly by the five laws which controlled their fate - prodigality, the struggle for existence, variation, survival of the fittest, heredity. He believed that all creatures that live to-day are what they are because the laws of nature chose their ancestors for them.

Now connect the five links and apply the chain to last year's codfish. By the law of prodigality, thousands upon thousands of eggs were laid. Most of these were destroyed before hatching time came. After hatching, the struggle for existence began. By the law of variation these young codfish differed from one another as they continued the struggle. By the law of survival of the fittest only those who were 
most fit to survive were able to hold to life long enough to become ancestors. By the law of heredity the characters of those that did survive were passed on to their codfish descendants.

Scientists are still discussing Darwin's chain. Some put the emphasis on this link, some on that, but all agree in his claim that, even as all kinds of pigeons are descended from the same original ancestor, so too are all kinds of fish descended from their original ancestor, all kinds of birds from theirs, all mammals from theirs, and so on through the entire list.

With one accord, indeed, scientists of to-day accept Darwin's conclusion that, from the beginning of time until now, laws of nature have controlled the changing forms of life ; that each living creature of to-day is joined by close connection to its ancestors of the past; that living creatures both of the past and of the present move through the ages as a procession marching in lock step, and that every form of life is linked to distant ancestors by an endless chain of cause and effect.

Through Darwin's discoveries we see that creative power has raised a structure of life on the earth which is welded together from foundation to summit. The evidences of this evolution are about us on every hand, and the next chapter points out a few of them. 


\section{CHAPTER X}

\section{EVIDENCES OF EVOLUTION}

Watch swimming fish in any pond or aquarium; even goldfish in a glass jar will answer the purpose. Notice those two small flaps, one on each side of the head. See them open and shut, and open and shut again, with never-failing regularity. They cover what are known as the gill-slits. These

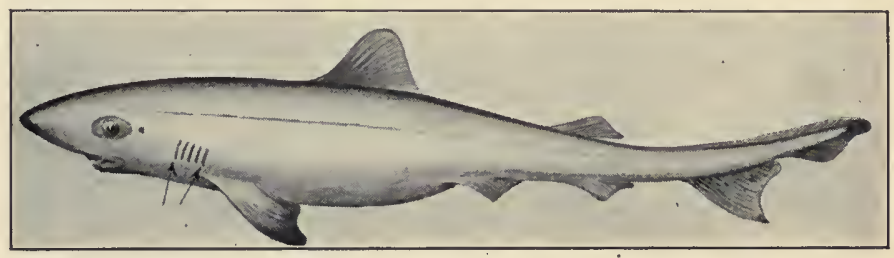

Dogfish with Gill-Slits Where the ARrows point

slits open out from the gills, and gills are the breathing apparatus of the fish. ${ }^{1}$

Notice also that the mouth of the fish is open, too, and that, although he seems to be swallowing mouthful after mouthful of water, he really gets nothing to eat. The truth is, he is simply breathing with his mouth open. If he should shut his mouth and keep it shut, he would die of suffocation. To keep alive he needs oxygen as much as we do, and the only way he can get it is by taking water into his-mouth and sending

${ }^{1}$ Blood which circulates in the membranes of the gills takes oxygen from water which passes over them, just as blood which circulates in the membranes of lung cells takes oxygen from the air which enters the lungs. 
it out again through his gills within his gill-slits. As the water passes along, the red-blood corpuscles in the gills take out all the oxygen they need.

When fish are drawn out of water and left on land, they die because they cannot get oxygen from the water in their usual way, through their gills. When we are held under water, we die because we cannot get oxygen from the air in our usual way, through the lungs.

Since this is the case, zoölogists ${ }^{1}$ expected to find gillslits in embryo ${ }^{2}$ fish, and lungs in the embryos of animals that take their oxygen directly from the air. Imagine, then, the surprise of these men when they found gill-slits and lungs too in the embryo of all vertebrates, whether they were fish or not.

Birds that are to live in trees and never swim, mice and men, monkeys and elephants, snakes and bats and vertebrate beasts of every sort - all these have gill-slits in the neck during the embryo stage. At the same time those that are to breathe air after birth have embryo lungs too.

And this is not all. Even in Darwin's day the bodies of animals held other mysteries which no man could explain. It was well known that full-grown whales have rudiments ${ }^{3}$ of hind legs concealed under the flesh; that embryo whales have rudimentary teeth, although no grown whale has ever been known to have a tooth in his head; that the python and the boa have rudiments of legs never used, never desired; that calves before they are born have beginnings of front teeth in the upper jaw which never cut through the gums after birth. Notice that no cow has front teeth on the upper jaw.

1 A zoölogist is a student of animal life.

2 Before birth a creature is called an embryo.

${ }^{3} \mathrm{~A}$ rudiment is the beginning or foundation of any part or organ. 
The list might be made still longer. But no one explained these rudiments of legs, teeth, gill-slits, etc. until Darwin came with his five-linked chain and his proofs. He said that through millions of years unused parts of the body become more and more inefficient, until, in course of time, they have no power left.

To prove this, think of the ancestral horse and his useless toes. Think of the fish in the dark recesses of Mammoth Cave, Kentucky. They are blind, but they have rudiments of eyes.

Parasites in particular show the same degeneration from lack of use. One of the most extraordinary among these is the sacculina, as described by Dr. David Starr Jordan.

It begins life by looking very much like a young crab. Both creatures have feelers, swimming apparatus, eyes, heart, brain, etc. But soon a change sets in. The crab, on the one hand, goes on developing. Feelers grow longer, brain grows bigger, eyes continue active, the heart never stops beating. In other words, the crab keeps active in every part and grows as it should. Not so with the sacculina. Soon after birth it fastens itself to the body of any convenient crab and stays there the rest of its life. It first sends a slender feeler down into the blood stream of the crab. This feeler lengthens each day like a ramifying root. At the same time branches of the root grow in this direction and that until they have entered the entire system of crab blood vessels. And as they ramify, they draw up from the blood of the crab all the nourishment the sacculina needs. Feelers have therefore no work to do in hunting for food. Eyes are needed no longer. Heart and brain cease to serve. As a result they disappear, one after the other, until the sacculina finds itself nothing but a sac fastened to the body of the crab - a sac 
with root processes and reproductive organs. Everything else is gone, and, as the illustration shows, the parasite finally looks more like a growth of the crab itself than like a separate creature. The sacculina lives as long as the crab lives, and when the crab dies, it must die too.

Now this record is simply an illustration of the result of disuse. Somewhat the same thing happens in other animals.

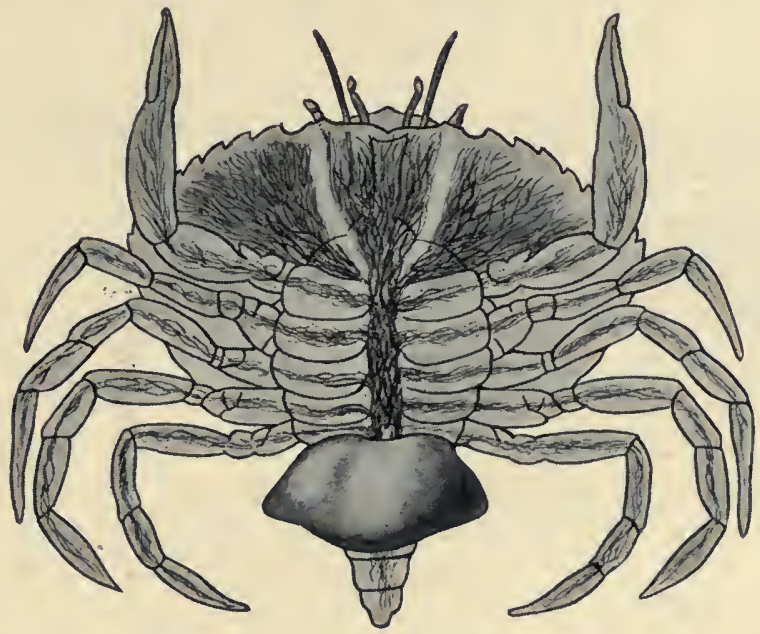

Sacculina on the ABdomen of a CRAB

Notice how the root processes of this parasite ramify through the legs and the body of the crab. (Adapted from Parker and Haswell)

In many cases, however, unused parts remain as mere rudiments through later generations. Darwin makes three statements concerning this whole matter, which may be condensed as follows :

1. All organs degenerate by disuse.

2. As any race of animals grows more and more successful in the struggle for existence, it develops new organs and 
may stop using old ones. If it stops using any part of its body, that part may be inherited as a rudiment.

3. The embryo of many vertebrates tells by its different parts what the history of the evolution of its ancestors has . been.

For example, when we find rudimentary teeth in the front upper jaw of an embryo calf, we know that once upon a time the ancestors of this calf had well-developed upper front teeth and used them for chewing. When we find rudimentary legs hidden under the flesh of full-grown whales, we know that, in the ages of the past, whale ancestors used legs instead of fins for locomotion.

So, too, with gill-slits. When we find rudiments of these in any embryo, we know that somewhere back in bygone ages the ancestors of this particular embryo lived in water and breathed through gill-slits.

Evidently, then, each rudiment is nothing less than a signboard - a reminder of the road by which developing creatures have traveled from the past to the present. Each is a so-called ancestral reminiscence. Each declares that in the struggle for existence this organ or that had to be given up, and that other organs were developed instead.

Our modern whale tells the story of a double change. Today he is a queer combination - a mammal that lives in water and uses lungs for breathing. But his rudimentary legs and his rudimentary teeth prove that at some time in the past his ancestors were out-and-out land animals that roamed the fields on sturdy legs and used good-sized teeth for chewing.

Also, by his embryonic gill-slits the same whale tells us that even before he was a land animal his ancestors were water animals with gill-slits for their breathing apparatus. 
At the present time every whale in every ocean uses lungs and not gills when he breathes. Nevertheless, as a reminder of the ancient road which their ancestors traveled, every embryo of every whale has the double outfit - lungs and gill-slits too.

Thus it is that rudiments repeat over and over again the long-drawn history of whale life. They show how the struggle for existence drove some early ancestors first from water to land, then back again from land to water. Scientists say that

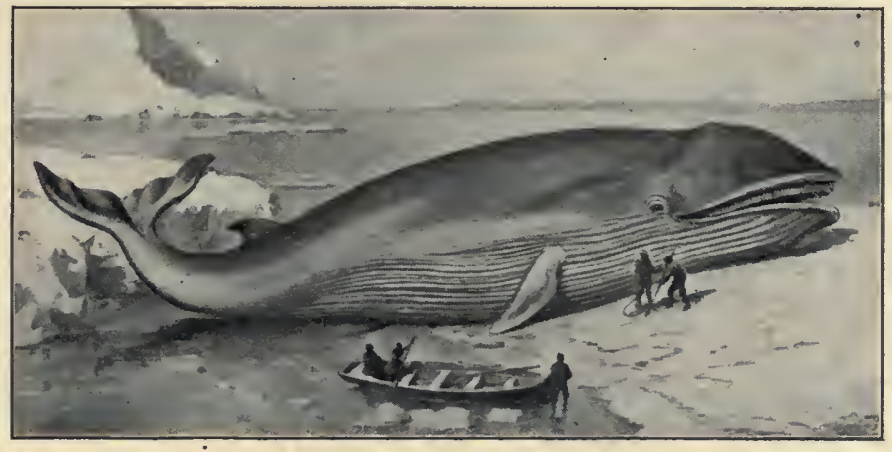

Rorqual, the Giant of the Arctic Seas

One of these whales, captured on the British coast, measured 95 feet in length and weighed 249 tons

by learning how to live in one environment after another, as they did, whales have shown that they were better fitted to survive than many of their fellow monsters who perished in the struggle. And all this lends a glow of romance to our modern whale, yet he himself is as indifferent as if no line of struggling ancestors had made him what he is.

For the sake of studying the evidences of evolution in close relation to each other, they are now summarized in five separate statements. 
I. Structural evidence derived from the form and general make-up of animals. It is often found in rudimentary bones and organs - leg bones of the whale, for example, toe bones of the horse, etc. Darwin himself was thinking of structural evidence when he wrote, "What can be more curious than that the hand of man, formed for grasping, the leg of the horse, the paddle of the porcupine, and the wing of the bat, should all be constructed on the same pattern, and should include the same bones in the same relative position."

2. Embryological evidence. This includes such rudiments as are found in the embryo alone - gill-slits, for example. Without this important embryological evidence we should not so much as suspect that in early ages all vertebrates lived in the water.

3. Geological evidence gathered from fossil bones etc. This gives us the pedigree of the horse back to his five-toed ancestors, and shows what kind of creatures lived on the earth before man himself arrived.

4. Geographical evidence. This shows that creatures which are most alike are found nearest together.

5. Experimental evidence. Man gets this for himself when he chooses different varieties and breeds new species of animals.

Taken all together, these five kinds of evidence prove that at some time in the past all vertebrates were very much more alike than their descendants are to-day ; and, as we have seen, these present differences are the result of the combined action of environment and heredity ${ }^{1}$. The two, working together, have caused such specialization along different lines that we now have many different types of vertebrates. Some of these

1 "By heredity we mean organic resemblance based on descent." Castle. 
live in the air, some live in the water, and some, as ourselves, live on land.

And throughout the history of it all we see that in every case it was the fittest ancestors that were able to change their habits of life, able to save themselves from extinction when the

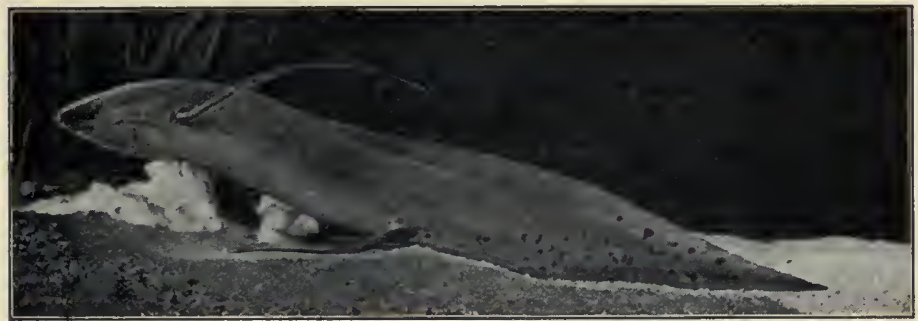

The LUNGFish THAT Lives bOTH ON LAND AND IN THE WATER

In 1913 this fish was sent alive from the Gambia region of Africa to the American Museum of Natural History in New York City. It came "coiled up in a kind of cocoon, deeply sunken in a large clod of earth which months before had been the bottom of a stream." There was an opening through the clod so that air reached the fish. This kind of fish "breathes by means of gills when in the water, but with a lung during the summer drought, inhaling and exhaling air as if it were a landliving animal." In its degree of development it belongs with fossil fish that lived millions of years ago, because it is a transitional type - a water animal that is becoming a land animal. The fish died soon after reaching New York, and its body is preserved in the Museum

struggle was on, and able to pass certain kinds of characters on to the next generation.

Thus it is that each generation takes its part in changing the history of later generations. But this is not all. The next chapter introduces another side of the subject. It shows what the difference is between characters that can be passed on and characters which can never be passed on by inheritance. 


\section{CHAPTER XI}

\section{ACQUIRED CHARACTERS AND MUTATIONS}

A young mother expressed the greatest disappointment over the fact that her daughter was not musical.

"I simply cannot understand it," she exclaimed. "Before the child was born I spent hours every day practicing the piano, because I was determined to have at least one musical person in the family. Does n't science say that we can stamp our children this way or that, before they are born? I have proved that we can't."

"Has she no musical ability whatever ?" I asked.

"None at all," was the answer; " neither have I ; neither has her father. That's precisely why I practiced so. I was trying to help the family out. I wanted to put musical power into it."

"And you failed?" I asked.

"Absolutely," was the answer.

"The trouble was with your own lack of information," I continued. She looked surprised, but I gave her no time to speak. "The process of evolution proves that we stamp our children according to what we are in ourselves, not according to what we make ourselves do. The doing is n't going to stamp children before they are born; it is the being that does. it. Is n't your daughter rather persistent?"

"Indeed she is," said the woman, looking at me in astonishment. "She's the most persistent thing you ever saw. But what gave you the idea? You have n't even seen her." 
"No," I answered, "but from your story I see that you yourself are persistent, not musical. Where was her musical taste to come from if neither you nor her father had it? You must n't blame her. Laws of nature are responsible."

This true story shows how it is that uninformed people often expect to secure what they desire without any reference to the laws of nature.

For three hundred years and over, Chinese mothers bound the feet of
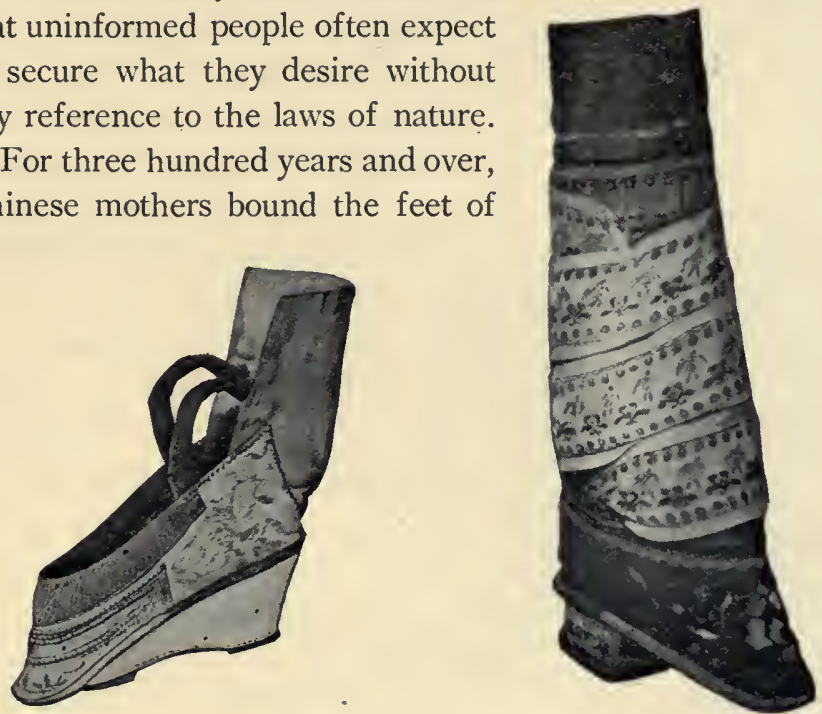

Chinese Shoes Two and One Half Inches Long

The one on the left has been worn; the one on the right shows how the foot was bandaged and cramped above the shoe

their young daughters, and from generation to generation those feet were cramped from girlhood to middle age, old age, and death. - Surely, if ever an acquired character ${ }^{1}$ was to be

1 An acquired character is secured by an individual during his own life, not by inheritance. Professor Weismann was the first scientist to give the words acquired character their present meaning. He says, "Acquired characters are those which result from external influence upon the organism, in contrast to such as spring from the constitution of the germ." 
inherited by oncoming generations of girls, this was the one. Mothers and grandmothers, great-grandmothers and greatgreat-grandmothers, back in direct line through all these generations, had done what they could to compel Chinese women to have small feet. And what success did they have? Each baby born in each generation had as perfect feet as if no ancestral bones had ever been deformed. Moreover, when those feet were allowed to grow, they became as large and well shaped as if there never had been any foot-binding in China.

This illustrates the fate of acquired characters. Facts show that they are not passed on. A woman may crimp her hair from the cradle to the grave, but unless she marries a man with curly hair, or unless there has been curly hair somewhere back in the ancestry of the father or the mother, she will not succeed in giving curly hair to her children or to her children's children.

Other characters are acquired, too. Eyes that have been weakened through overstrain; hands calloused through rough work; faces tanned through exposure; firm or flabby muscles; bent or straight backs; stiff or limber joints - these and many others are acquired characters. They can never reach the next generation through inheritance.

In the flower gardens of Japan there are trees so dwarfed by human art that orange, pine, and plum are in full bloom and bearing fruit when they are no more than a foot high. Judging from appearances, these trees are a race by themselves, and one would expect to find nothing but dwarfs among their descendants. But, strange to say, no seed of a tree that was dwarfed ever grows into a dwarfed descendant. Each successive generation has to be crippled and deformed and compelled to stay small by the aid of man. 
Dogs and sheep and horses in England have had their tails cut off for very many generations. Yet each pup, colt, and lamb born of these tail-docked ancestors has as normal a tail as if its ancestors had never endured any amputation. The acquired character of short tail has never been passed on and never will be.

With such facts in mind we naturally ask how short-tailed cats came into existence, and how it is that such cats are able to pass on the short-tailed character. A series of rather startling facts points the way to a probable answer. They deal with what are called mutations. In more ordinary language a mutation is referred to as a sport, and a sport might be described as a living novelty which cannot be explained by its ancestors.

To illustrate this :

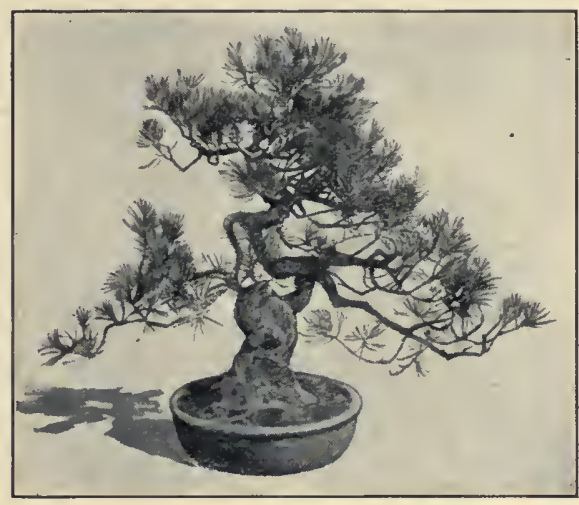

Full-Grown Japanese Pine Tree

Dwarfed by human skill In Paraguay, in the midst of an ordinary herd of long-horned cattle there appeared one day a young bull born without horns. This was in 1770 . Not an ancestor of that small animal had been hornless, yet until he died he remained as hornless as when he was born. $\mathrm{He}$ was a mutation - a sport.

An animal without horns is so easy to manage that this one pleased his owners, and they wished to have others like him. But as he was the only one of his kind, his pairing had 
to be done with ordinary horned mates. The results were unexpected certainly, and the owners were astonished. So many of his descendants had no horns that in the course of time there was established a race of hornless cattle from

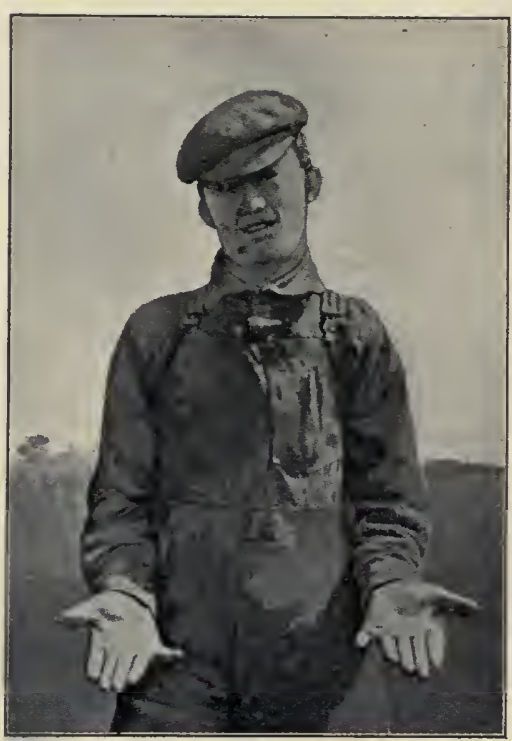

A Case of Polydactylism

The boy's father had twelve fingers and twelve toes, but the fingers were boneless. (Photograph by Professor Scott.) (From "Heredity in Relation to Eugenics," by C.B. Davenport) horned ancestors.

Darwin tells us that short-legged:Ancon sheep started in the same way - that in a herd of longlegged sheep there appeared one day this one little lamb with short legs ; that it lived to grow up and become an ancestor; that among its own descendants there were several short-legged sheep. These could not jump fences and escape from the fold; therefore sheep raisers selected them as ancestors of succeeding generations. As a result, short-legged sheep are now the chosen type. They are found the world over, and appreciated everywhere.

Mr. Poulton describes a family of cats with an extra toe. The first one came as a mutation. After this, for seven generations of that family, the feet of all the kittens and cats were faithfully examined, and, by actual count, the majority of them were found to be supplied with one or two extra toes, making six or seven toes on each foot. 
From one point of view this is a calamity even for cats. Think, then, of the misfortune it is for human beings! Yet such cases are on record. Professor Scott gives the photograph of a boy who began life with six fingers on each hand and six toes on each foot. His father had had the same number. One of his brothers had extra toes, another brother had extra toes with one extra finger on his left hand, a sister had
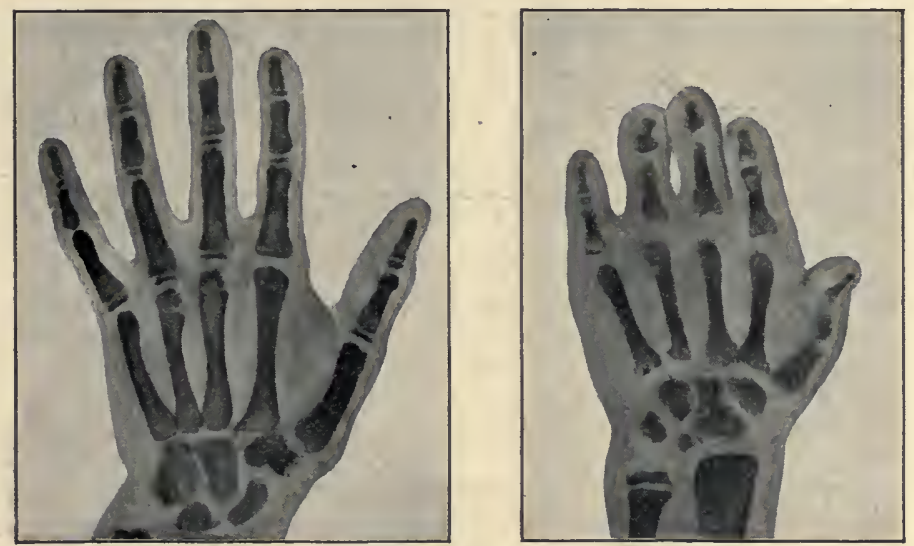

Radiograph of Normal and Abnormal Hand

Notice that one hand has three joints to each finger, while the other has but two. (Photograph by Drinkwater.) (From "Mendel's Principles of Heredity," by W. Bateson)

extra toes only, while five brothers and sisters had perfectly natural hands and feet. The condition of having too many fingers is called polydactylism.

Besides this there is brachydactylism. The worditself means "short-fingeredness." All we know about the following case is that the woman had two joints instead of three joints to each finger. She married a man with perfectly normal, threejointed fingers. They had eleven children, and facts are known 
about eight of them. Among these, as the diagram shows, four had short fingers and four had normal fingers.

Study the diagram and see that in the next generation there were seven short-fingered persons and five that were normal.

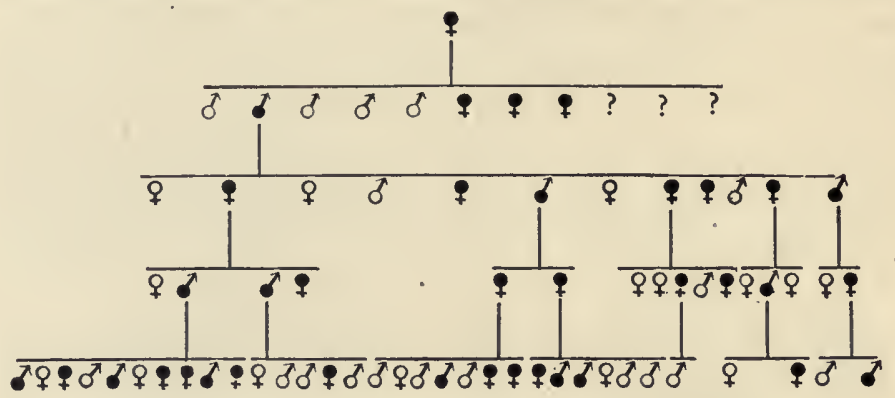

Brachydactylism through Five Generations

The family lived in Pennsylvania, and, as Dr. Castle states, "in no case was an abnormal member of the family known to have married any but an unrelated normal individual." Notice, however, that about half of the descendants were afflicted with brachydactylism. (From "Heredity," by WV. E. Castle) $\bigcirc \bigcirc \begin{gathered}\text { Male and female respectively, not possessing the trait under } \\ \text { consideration. }\end{gathered}$

1 Male and female possessing the trait.

Unknown sex, normal or affected.

Neither presence nor absence of trait can be affirmed.

(3) Indicates number of children.

○

Symbols used in Pedigrees

(As adopted by the Galton Eugenics Laboratory) 
The printed record of the family stops with the fifth generation, but out in the world, where the descendants of those people continue to live and to multiply, the misfortune of their fingers still goes on, and the number of those who have this misfortune increases with each generation

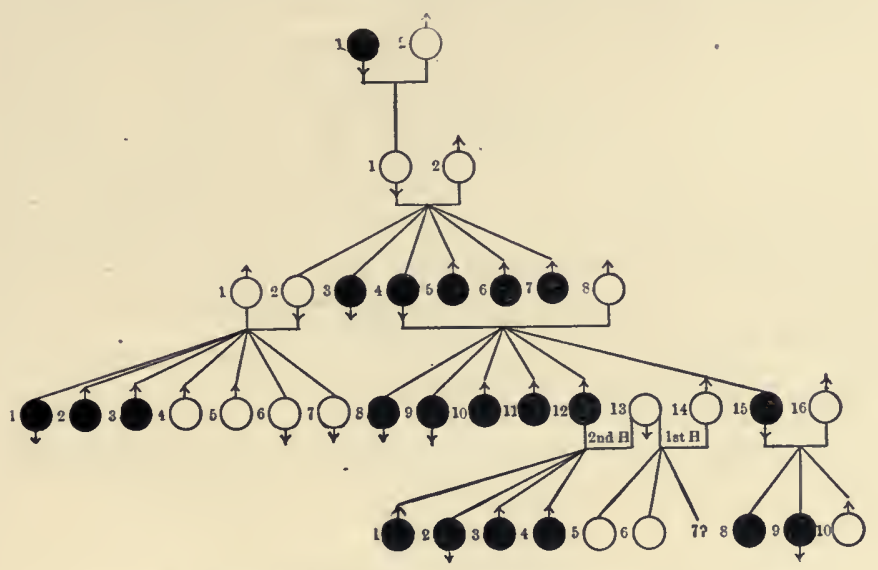

Smith and Norivell's Case showing Polydactylism

(From the "Treasury of Human Inheritance")

We see, then, that a character which begins as a mutation ${ }^{1}$ marches on through the generations without any regard to

1 In 1885 Professor Hugo de Vries of Holland came upon an astonishing primrose plant. It grew in a deserted potato field near Amsterdam, and it had many unexpected descendants. Among these "some had few branches instead of many; some had small flowers instead of large; some had quite different leaves, and so on." Every now and then, also, a primrose hybrid would have descendants quite like itself, and the new characters would go on from one generation to the next without change. A new species had come unannounced into the field, and it was able to stay there because it had descendants like itself. De Vries found many such cases among his primrose plants, and it was he who first called them mutations. The word is now used by all who study the laws of evolution. 
the wishes of those who suffer from it or of those who are blessed by it. And this points the difference between a mutation and an acquired character.

An acquired character cannot be inherited; a mutation is inherited. The difference between the two is striking. And this explains why mutations have done so much for past generations of living creatures, for if a mutation gave its owner any advantage in the struggle for existence, - if it made the creature in the least degree more fit to survive, - through the law of inheritance it was sure to play an important part in changing succeeding generations of descendants.

No mutations have taught plainer lessons than do those which Dr. Tower brought about among his American potato bugs. These are discussed in the thirteenth and fourteenth chapters. Just now, however, we turn to the law of isolation as it is illustrated by snail shells on the Hawaiian Islands. 


\section{CHAPTER XII}

\section{ISOLATION; OR LAND SHELLS ON HAWAII}

Imagine yourself on the Hawaiian Islands, ${ }^{1}$ in $185^{2}$. You are on horseback, on the island of Oahu, riding from valley.

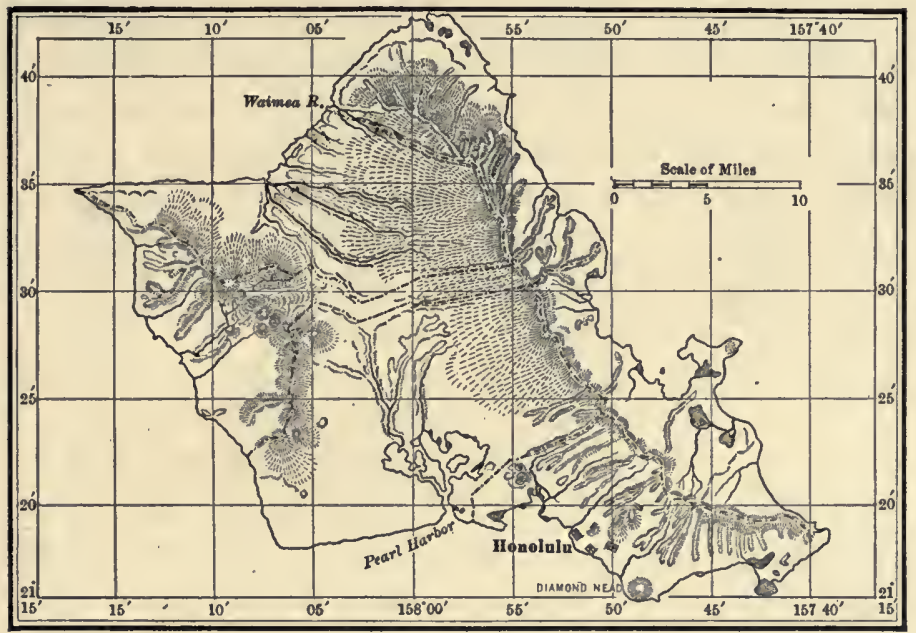

The Island of OAHU

to valley, hunting for land shells. Your guide is an enthusiastic young American student.

1 The Hawaiian Islands take their name from the largest island of the group. They are of volcanic origin, lie just within the tropics, and are 2500 miles from San Francisco. Because of their great beauty they are called The Paradise of the Pacific. 
Look under the trees as he does; examine the trunks, the branches, the leaves. You will find snail shells clinging in each place. Notice their variety, their shape, their location. Some are almost an inch long; others are so small that it takes five to measure one inch. Some are fragile as the frailest china; others are stout enough to endure rough handling.

In color they run all the way from bright green and yellow to the softest shades of brown, with touches of blue and pink and white. Indeed, in coloring, no gems could be more lovely.

The island of Oahu is forty-six miles long and twentyfive miles wide. A mountain range stretches through it from northwest to southeast. Wooded valleys trail downward from this central mountain range. These valleys are very narrow, very deep, and close together. Here it was that, in I 852, John Gulick gathered his snail shells and found that on Oahu alone there are between two and three hundred species of the same family of snails.

Some lived on the ground; some were on the under side of the leaves of low shrubs; some on the broad branches of the kukui tree. Others lived in sunlight on the ridges between the higher parts of the valleys, while still others always stayed in the damp, shaded forests of the valleys. And the special point to bear in mind is, that from generation to generation each species stayed where it started. It never left its special tree, shrub, or rock unless it was carried away by windstorm or by birds.

At the very time that John Gulick gathered his shells, he did the one thing which made his whole collection priceless afterwards. He not only found old shells and labeled them, found new shells and gave them names, but he also made careful note of the exact place where each separate shell had 
been found - whether in this valley or that; whether on this kind of tree, on that variety of "shrub, or under leaves on the ground. He was indeed doing what scientists now insist must always be done to make a collection of any value from the scientific point of view. In those days, however, and in that distant land, John Gulick was the only person who so much as dreamed of doing this careful work.

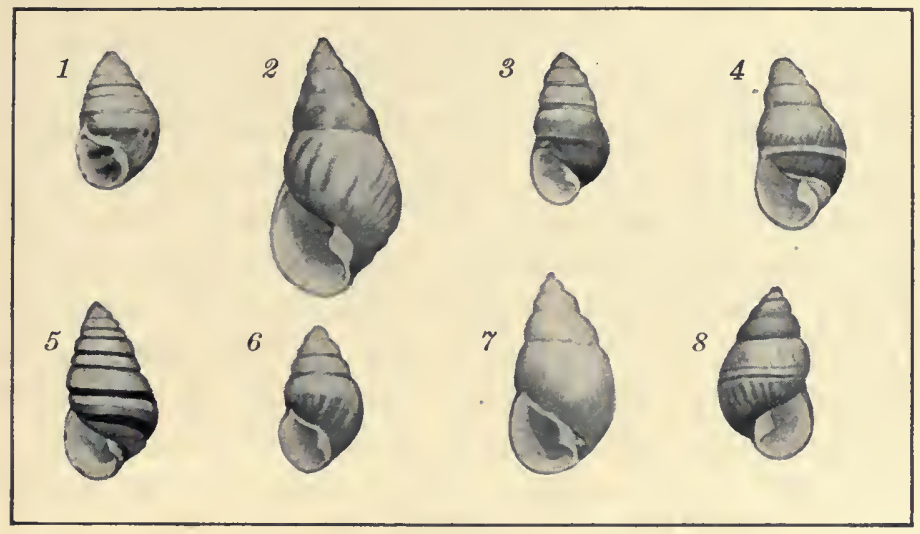

A Few of Dr. Gulick's Shells

1, yellow-white with a tinge of green and dark stripes; 2, soft yellow with white lining ; 3 , red-brown with white stripes and white lining; 4 , shaded pink with white bands and white lip; 5 , dark brown, light brown, and white; 6 , dark green shaded light, with bands of dark brown and yellow; 7 , white inside and outside, with touch of yellow on the lip; 8 , dark red-brown, shaded, with darker bands and white lining

"I was so much interested in the location," he says, "that I kept the name of every valley. I went around the island on horseback, starting at Koko Head and visiting all the valleys in turn. The shells were actually found by the $\mathrm{Ha}$ waiian boys. I would ride into a valley and tell the boys that I would come in a few days and pay them for the land shells they found, but I knew the valley where they came from." 
He also saw that in the same valley, on separate trees, there were often several varieties of the same species. In one case he even found fifteen different species of the same genus in five neighboring valleys; and these valleys were so small that, altogether, the ground they covered was less than five miles long by two miles wide.

All this perplexed him. And although he bought and read Darwin's "Voyage of the Beagle," it gave him no help. ${ }^{1}$

As he continued to gather his shells, to study them, and to label them, he constantly looked for points that were alike and for points that were unlike. And in doing this he noticed that species which lived closest together, on the same trees or in the same valley, were very much alike.

He then arranged his shells according to the exact spot they came from. And now he saw that the nearer together they were, the more alike; the farther apart, the more unlike. These various facts led him to ask himself two questions :

I. Why should so many species have been created so near to each other ? ${ }^{2}$

2. Why should there be such an extraordinary number of short steps between the different species?

While he asked these questions and puzzled his wits for answers, John Gulick little thought that those treasured shells of his were destined to travel back and forth to America and round the world with him; that he was to talk with Darwin himself about them; and that, in the end, his own answer to his own questions was to help solve the great problem of evolution. Yet all this came to pass.

1 The "Origin of Species" was not written until years later.

${ }^{2}$ In those days men believed that each species was created independently of all the others. 
In 1872 , twenty years after his shells were gathered, Dr. Gulick wrote out the answers to his questions.

He said that on the Hawaiian Islands nature had acted like a careful breeder. It had kept certain groups from mating with other groups, even when they lived very near together. And he shows how this was managed, step by step, from the beginning.

I. After these volcanic islands had been formed, a few snails drifted to them from elsewhere.

2. These first snails multiplied where they were and, since they were wretched travelers, they stayed in the same place for numberless generations.

3. In the course of time a few were carried off by birds, or by wind or flood, or on a broken branch, and left in another part of the same valley, or perhaps on the top of a neighboring tree.

4. These snails stayed where they were dropped; they multiplied in their new home and had no chance whatever to mate with the parent stock or with any other snails in any other place. For this reason each new group of descendants became slightly different from its own immediate ancestors, and more different yet from all the other ancestors farther back. It became different because it started with a different average.

To make this last statement plain, imagine seven birds with beaks as long as shown in the illustration on the next page. Also imagine that two of the birds flew off to a new locality. Now notice the difference in the average length of the beaks in the two groups.

The same law of average holds true with snails. When a few of these are swept away from the original group, the average size or shape of this new, smaller group is sure to 
be different from the average size and shape of the first group, and in general it is the average that shows itself in the descendants of each new colony.

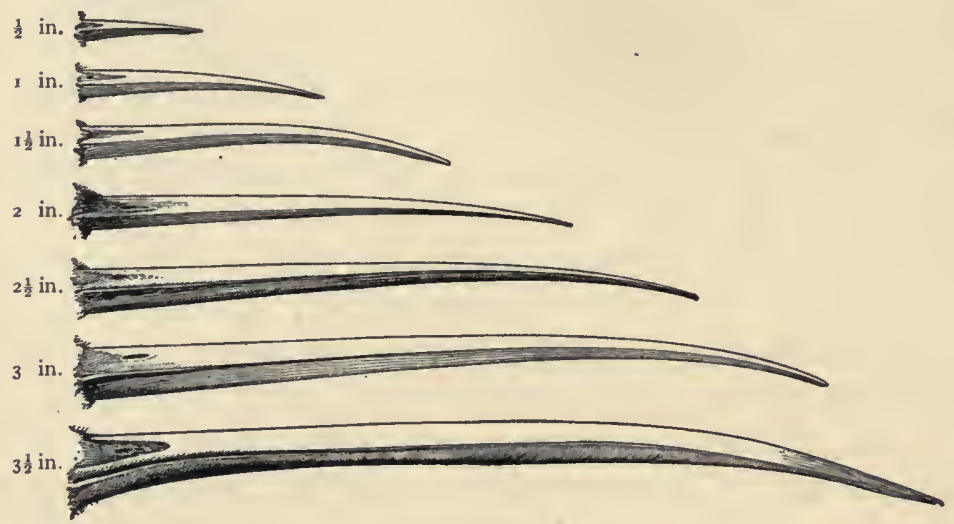

First Group

Average length of beaks in this group is two inches 1
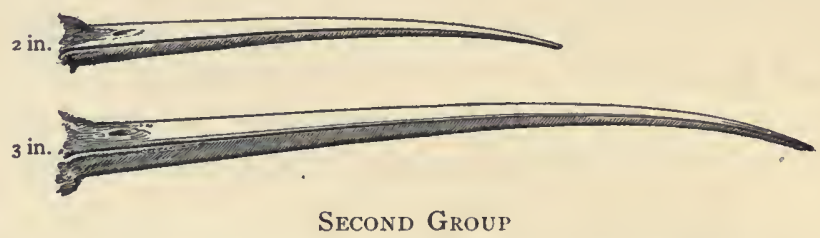

Average length of beaks in this group is two and one half inches 1

This, then, explains the short steps that sprang up, one from the other, among the snails of Hawaii. There is an extraordinary number of varieties and species, for two reasons :

${ }^{1}$ The average is found by adding all the lengths together and dividing the sum by the number of beaks. 


\section{ISOLATION; OR LAND SHELLS ON HAWAII 87}

I. Because the snails were blown along or moved along in 'short stages.

2. Because each colony was permanently separated from all the other colonies, and because each had its own average.

Let colony after colony be started in this way, let time go on for unnumbered snail generations, and we should expect to find precisely what we do find - a series of colonies separated from each other by short steps of difference. Then, too, we should expect to find that the nearer they are to each other, the more alike they will be ; the farther apart, the more unlike. This also is what has happened to snail shells on Hawaii.

Dr. Gulick brings these facts out and says that any separation which prevents one colony from mating with another colony is rightly called isolation. He speaks of geographic isolation, when snails in one valley or on one tree have no chance to mate with snails in another valley or on another tree, or when snails that live under stones never meet those that live on tree tops. He speaks of food isolation, when different groups live on different kinds of food; and he assures us that anything which keeps colonies permanently apart, so that mating is impossible, means isolation for them. He also says that genuine isolation of this sort results at last in a new species.

This was Dr. Gulick's discovery. By means of it he added the law of isolation to Darwin's five-linked chain, and by doing this he made the chain itself so much the stronger.

Human beings as well as snails, plants as well as animals, are controlled by the same law of isolation. The next chapter will show that colonies which mix freely with each other have the smallest number of species. 


\section{CHAPTER XIII}

\section{CHANGED ENVIRONMENT FOR LEPTINOTARSA}

Kansas will never forget the year I862. Potato bugs had arrived. They were crossing the state, destroying the crops and driving the farmers to despair. One afflicted man. wrote.

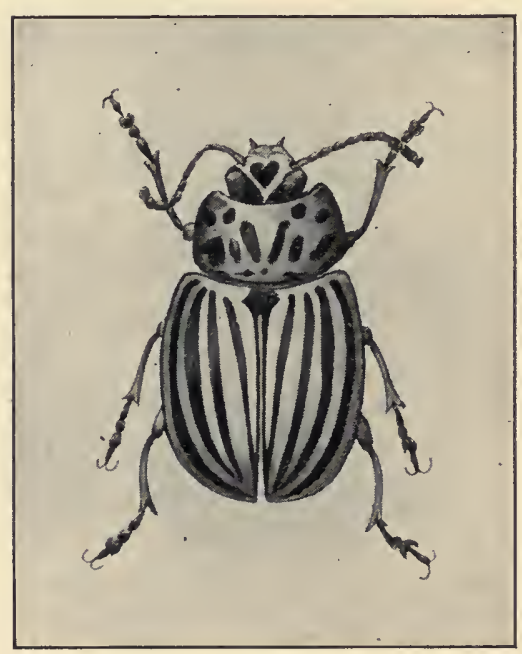

LEPTINOTARSA DECEMLINEATA, THE TRAVELER

Color, yellow with black stripes; length, about one third of an inch to the editor of the $\mathrm{Val}$ ley Farmer about it :

"I cultivate about ten acres of land," he says, "for the purpose of raising potatoes for my hotel; it is situated on the prairie land. Last August, soon after a heavy shower of rain, these bugs suddenly made their appearance in large numbers on the potato vines. They were so numerous that in many instances they would almost cover the whole vine. It is no exaggeration when I tell you that we have often, in a very short time, gathered as many as two bushels of them. When cold weather set in, they disappeared. Early this spring I was setting out some apple 
trees, and away down in the hard, yellow clay I found these bugs, apparently dead, but put them in the sun and they immediately came to life. They have again made their appearance in my garden in large numbers. Last year they ate up everything green on the potato vines, then commenced on the tomatoes, and so on, eating up everything green."

It seems that the ancestors of these beetles had moved up by short stages from Mexico to Nebraska; that on the way they ate certain plants that pleased them, but that they knew nothing about potatoes until they reached Omaha City in I 859. And here it was that they had their first taste of what seemed to them a delicious new food.

They crawled over the potato leaves, nibbled at them, and liked them so well that, ever after, wherever the farmer went, planting his potatoes, there too went the potato-bug beetle to enjoy them. Everywhere the beetle destroyed the crops, and everywhere the farmer did what he could to destroy the beetle.

It was a hand-to-hand fight, and the record of it is given by Dr. Tower in what he calls "The Chronological History of the Dispersal of Leptinotarsa decemlineata, 1859 to $1904 . " 1$

This record shows how the beetles worked their way from west to east, how long they took for the journey, and how they earned for themselves the nickname of potato bug. Their real name - their scientific name - is Leptinotarsa decemlineata, a name too long for everyday use but quite important to the scientist.

Here are a few extracts quoted from the record of the travels of Leptinotarsa decemlineata.

1 This is one division of Dr. Tower's book entitled "Evolution in Chrysomelid Beetles." 
I864. "The beetle has.crossed the Mississippi River into Illinois at several points.... It is committing the most destructive ravages on the potato crop in the vicinity of Warsaw, Illinois, but it has not yet reached a point lying thirty miles east of us in such numbers as to be noticed by the farmers."

I865. If reports are correct, "the insect has traveled three hundred and sixty miles in six years. At this rate it will reach the Atlantic in fourteen years (i.e. I 879).'

I868. A few advance agents of the moving army appeared in Ohio. The army itself was still one hundred miles to the rear but coming steadily on. Dr. Tower says that this advance guard, no doubt, traveled by accident on the coal barges which passed up and down the Ohio River. They were blown onto these barges while on the wing.

$I 87 I$. "The chief event of the history of this year's spread is the invasion of Canada." A man describing the way they travel writes: "In the spring the Detroit River was swarming with the beetles, and they were crossing Lake Erie on ships, chips, staves, and any floating object."

I874. "The center of the interest was along the Atlantic coast, where in many places the beetle was abundant and did much damage."

I875. "At the beginning of this year the beetle was distributed along the seacoast from New York to Chesapeake Bay, and by the end it had overrun most of the remaining territory of the coast states. It reached Boston, Massachusetts, in the autumn. It penetrated farther into Vermont and was reported from New Hampshire and Maine."

1876 . "It is related that they were washed ashore in such numbers as to poison the air with the 'noxious vapors' arising from their decaying bodies." The captain of a New London vessel relates that while at sea (Long Island. Sound) 
they "boarded him in such numbers that the hatches had to be closed. ... They were abundant everywhere and by the end of the year had overrun the entire northern and eastern part of the United States, excepting Maine."

Sometimes the masses moved faster, sometimes slower, but always they went forward. Like the Israelites of old, they lived and journeyed and died as they traveled.

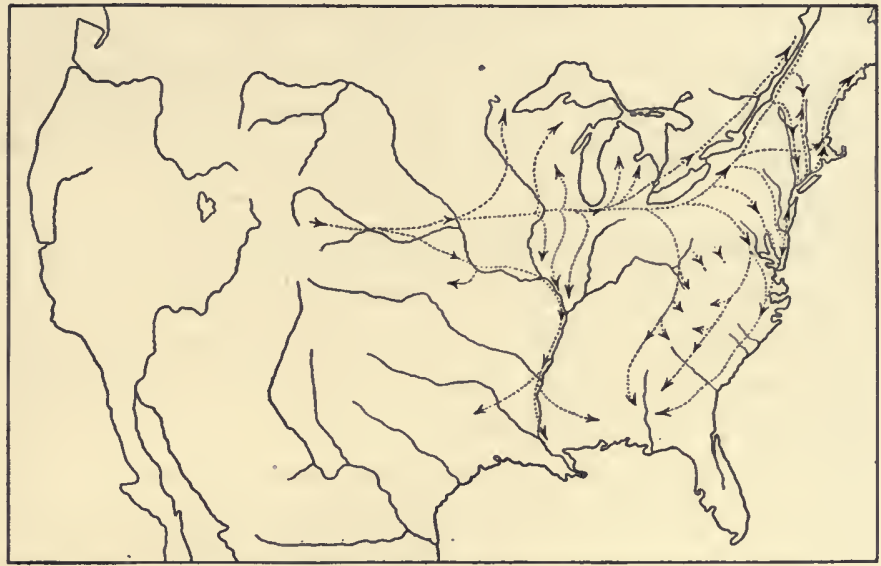

Map of the United States and Lower Canada

This shows the chief trends of migration of Leptinotarsa decemlineata between 1859 and 1904. (After W. L. Tower)

It took sixteen years for them to go from Omaha to Boston. Meanwhile every European nation watched the progress of the army and grew anxious. If beetles could cross the Mississippi River, if they could span Lake Erie and reach Canada, what was to hinder them from taking ship for Europe? What was to save that side of the ocean from the beetle raids of this side, and what should be done as preparation for the possibility of such an invasion? 
Different governments asked themselves these questions as they watched the steady advance of the tireless travelers. Fortunately Europe knew how to save herself. Her weapon was scientific information about the beetle itself, about its power to eat all sorts of green and growing things, and about the way it travels. Full directions were given as to what must be done at once if any beetle showed itself in Europe.

In Germany schoolmasters taught the facts to the children in the schools and gave public lectures to older people. France printed an elaborate bulletin for everybody to read.

Then, in 1876 , came the expected test. Beetles had arrived. They had crossed the Atlantic by ship from America. They were found in England, Sweden, and Norway. But, thanks to the bulletins, the school-teachers, and the children, people recognized them at once, captured them, and killed them. Science saved the country then and will keep on saving it so long as the people are vigilant. But what if vigilance should let go?

Dr. Tower says that "when this happens, the beetle will spread as it did in this country, until it is found in all the countries of Europe in which it is possible to live."

Such is the meager outline of the history of the migration of the potato bug from Omaha in the west to Europe in the east ; and it points the lesson of environment. By what they did these beetles proved that they could live in any surroundings where they could find food enough.

It mattered not whether the place was hot or cold, damp or dry, covered by shadows or exposed to sunshine; whether it were on a mountain top, on a wide plain, or in a valley. Nothing mattered to the beetles except their food. Wherever there was food enough, there they multiplied fastest; and where they multiplied fastest, there they provided the largest 
numbers to be moved onward or to be blown forward as accident might dictate.

Still they were neither eating nor traveling all the time. Dr. Tower says that most beetles spend from three to five months a year underground in a state of torpor, taking no part in life's activities. But when spring comes and the days are warm, then new life drives them aboveground again. They now creep and fly about and fall to eating spring leaves that are beginning to grow. It is at this time that the farmer is in despair. He cries, "The bugs are upon us!" He arms himself to defeat them. He picks them from the vines by the peckful and the bushel. He puts Paris green on the vines to kill the marauders. He digs long trenches across their pathway, waits until hundreds of thousands of them have fallen into these trenches, pours kerosene oil in after them, touches a match to it, and in a flash of light the beetles have been conquered. No beetle can survive an environment of Paris green or of fire. Man must therefore meet him with these weapons if he wishes to save his crops.

Now compare the snails of Hawaii with the potato bugs of America; and keep in sight the following facts :

I. On Oahu, an island forty-six miles long and twentyfive miles wide, there are between two and three hundred species of one great family of snails. In North America, in all the area of the Northern states and of Canada, there is but one species of potato bug.

2. On Oahu each species of snail must have its own kind of food, else it will die. In America potato bugs live on fifteen or twenty different kinds of plants.

3. Hawaiian snails move by creeping, and they do this slowly. American potato bugs not only creep but also walk and fly and are blown forward by the wind. 
4. The region covered by a single species of Hawaiian snail is often not over two or three square miles. The region covered by a single species of potato bug is as wide and as long as the continent of North America.

These facts, put together in this way, show that the power to migrate and to live in different kinds of environment has much to do with the number of species in this region or that. If potato bugs had been kept in narrow sections of the country, if they had been able to live on but one kind of food,

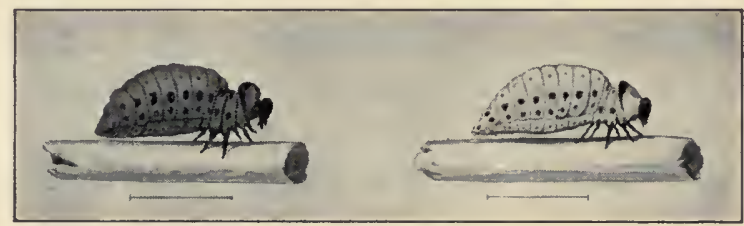

LEPTINOTARSA LARVAE

The dark one is bright red; the light one is bright yellow. Both are decorated with black spots, both help destroy the crops, and both will be changed into flying beetles. (From W. L. Tower)

if colonies had gone out from them rarely and at long intervals, if there had been no chance for different colonies to mix with each other, the potato bug would have ended by being divided into many species, as are the snails of Hawaii.

Instead, this potato bug lives in any environment. Neither soil nor climate daunts him. Storms and blizzards simply drive him on his way and improve his chances. In spite of all this, however, there are certain kinds of beetle environment which make all the difference in the world with his descendants of succeeding generations. The next chapter takes up this part of the subject. 


\section{CHAPTER XIV}

\section{NEW SPECIES THROUGH CHANGED ENVIRONMENT}

One of the interesting points about Leptinotarsa decemlineata is that they multiply at the rate of two generations a year. This means that a beetle has both children and grandchildren within twelve months. Dr. Tower describes the egg-laying process. It begins in the spring, soon after the beetles crawl out of their underground burrows.

A convenient leaf is chosen, and the beetle, well laden with her eggs, begins the serious work of laying from thirty to seventy-five of them in close succession. First "she allows a drop of yellow, oily fluid to escape" from her body. Upon this the egg is carefully dropped. "The fluid now hardens rapidly and cements the egg in place. One egg having been deposited, the female moves along a slight distance, and there places another by the side of the first, and.so on until there is a row of from five to ten eggs in a nearly straight line across the leaf. A second, third, fourth, and often as many as ten rows are thus laid, each of which is more or less closely placed to the previously laid row, and forms therewith a compact bunch."

Sometimes, instead of putting all her eggs on the same leaf, the beetle moves from place to place, leaving a few here and a few there, until she has deposited the thirty or seventyfive that are ready to be laid in close succession. Her entire number is about three hundred and seventy-five, but, as we have seen, they have to be laid in separate sets during the 
same season, because they are not all ready to leave the body at the same time. There are from four to ten days between the layings of two successive sets of eggs.

After the laying comes the hatching; and after the hatching, those young larvæ of the next generation eat green things in abundance and develop so fast that, within thirty-five days from the time they were eggs, they have not only been changed into crawling larvæ but also have become full-grown beetles with wings, ready to lay eggs on their own account.

Dr. Tower learned these facts while he studied beetles and carried on experiments with them in connection with The University of Chicago. He knew that every kind of beetle starts from a germ cell, ${ }^{1}$ and he proposed to do what he could to find out whether or not the power of germ cells can be influenced in this direction or that by any change in the surroundings of the parents before the next generation makes its appearance.

See how it was in the matter of color, for example. Dr. Tower first secured forty thousand beetles. These were sent to him from the potato fields of Massachusetts and Long Island, also from Ohio and Illinois, and when they reached Chicago he put them into glass cages and glass breeding tanks prepared for the purpose.

Each breeding place had its own special degree of heat or of cold, and each was kept at the same temperature through summer and through winter from I 893 to 1904. During these years many generations of beetles lived and died, and all the time Dr. Tower saw what was happening to the spots and the stripes that give the creatures their color.

When the eleven years were over, when both heat tests and cold tests were ended, he found that up to a certain

${ }^{1}$ All life starts from germ cells. The next chapter tells of this. 
point of heat or of cold the color of each next generation of beetles grew darker and richer, but that when either the heat or the cold was greater, the color grew lighter from one generation to the next, until it had quite faded out.

These experiments proved that the temperature of the surroundings in which beetles live and multiply influences the power of their germ cells to pass on shades of color to the next generation.

Dr. Tower was in the midst of these experiments when a serious calamity brought them abruptly to an end. Beetles' eggs with long pedigrees behind them were in the greenhouse waiting to be hatched. Young beetles with pedigrees quite as long were feeding and growing. Full-grown beetles were in fine condition. It was one of the hottest days in the summer of I904. Workmen were repairing the heating apparatus of the university, and, not knowing what might happen, they turned the heat on at full pressure. Soon every beetle was killed; every egg was put beyond the power of hatching. The record of these studies had to be closed. Dr. Tower had to make a new start with his investigations, and then it was that he printed his book and reported results up to the date of the overheating.

Still, even before the heat killed the beetles, another set of experiments had been going on which were of vast importance to biologists. Dr. Tower wished to know whether or not it makes any difference to the next generation if beetle parents are put into an unusual environment just before they lay their eggs, and at no other time.

He suspected that germ cells might be influenced by their environment while the body was getting them ready to be laid. If this were so, he knew that one set of eggs would be affected at a time. 
He could tell by the looks of any beetle whether she was about to lay her eggs or whether she had already done so. Accordingly, in 1902, just before egg-laying time came, he chose six pairs of beetles, put them into a very warm, damp. breeding place, and kept them there until they had laid 492 eggs. He called this set Lot A. He next put both the beetles and the eggs in normal conditions again. Here the beetles laid the rest of their eggs. There were 509 of them. They were labeled Lot B. The larvæ of both sets grew up together. As it happened, many of the eggs in both Lot A and Lot B did not hatch. Many làrvæ did not live. But we may imagine how carefully Dr. Tower watched those that did live to become ancestors. ${ }^{1}$ And he had his reward.

$\mathrm{He}$ tells us that the parents of these particular beetles were of the species Leptinotarsa multitaenita, and that they had been brought from Mexico. Now it seems that when beetles of this species are frightened, they "feign death," as it is called, by falling to the ground with their legs folded close. up against the body, and they lie there motionless until they consider it safe to unfold and be alive again.

But there is still another species of these same beetles in Mexico, called Leptinotarsa melanothorax. When these are frightened, they feign death and fall to the ground with their legs stiffened and stretched out in a straight line from the body. What, then, was Dr. Tower's surprise to find that all but ten of Lot A beetles, creatures that were direct descendants of multitaenita, were feigning death in quite correct melanothorax fashion. The damp-heat environment had so affected them through their parents that now, when the moment of fright came, they did not fold their legs up against their bodies as their ancestors had done, but stiffened them

1 Lot A produced 59 and Lot B 82 full-grown beetles. 
out and fell to the ground like bristling small porcupines. Moreover, their children and their children's children showed fright in the same way. Dr. Tower saw that his damp-heat environment had changed the leg habits of multitaenita beetles. It had made melanothorax beetles out of them, and they continued to be melanothorax beetles for succeeding generations. A wonder of this sort throws a flood of light on the laws of inheritance and on one of the methods of evolution.

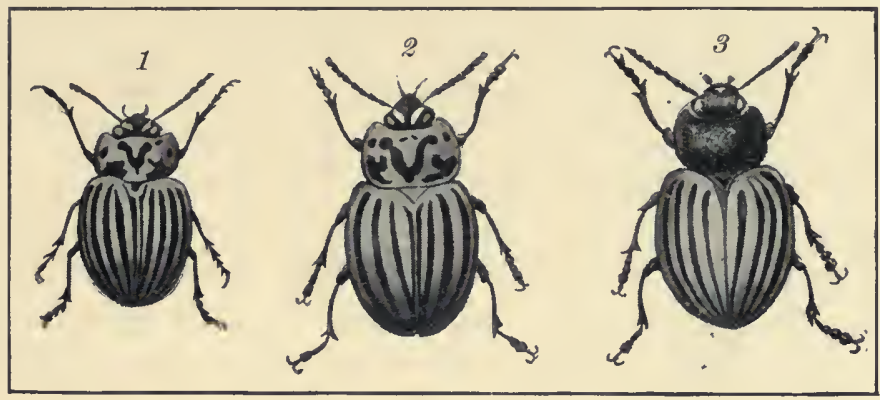

Mutations CoMPaRED

Leptinotarsa multitaenita (2) and two of its offspring that were mutations - rubicunda (I) and melanothorax (3). In their coloring 2 shows black stripes and marks on a yellow background; $\mathrm{I}$ has similar stripes and head markings on a red background; 3 is red with black stripes and a black neck. (After W. L. Tower)

The most notable part of Dr. Tower's work was the proof that, by giving beetles an unusual environment during the time that the eggs were maturing, before they are laid, germ cells may be influenced and a new species secured.

Now it matters little whether beetles feign death in one way or in another. But suppose there were some sort of environment which could change cells in such a way that the individuals of the next generation would be hopelessly damaged after birth. This subject will be studied later. Just now we turn our attention to the very beginnings of life for the next generation. 


\section{CHAPTER XV}

\section{BEGINNINGS OF THE NEXT GENERATION}

Professor Loeb in the United States and Professor Bataillon in France have accomplished a marvel with frogs' eggs.

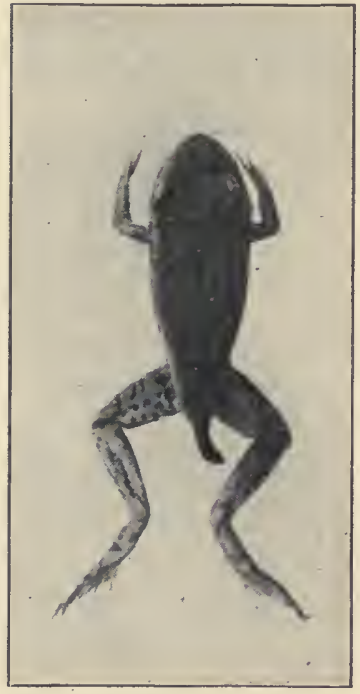

TADPOLE No. I

This tadpole developed from an unfertilized frog's egg that had been pricked with a platinum needle by Professor Loeb. It lived five months and passed almost beyond the tadpole stage. When it died it had all four legs and only the remnant of a tail. (Courtesy of Professor Loeb)

One thousand of these eggs were taken from the body of the mother before they were fertilized. They were put into a small dish and were pricked one after the other with the finest possible platinum needle. Water of the right warmth was poured over them to keep them moist, and the dish with its water and eggs was set aside while Professor Bataillon waited for results. ${ }^{1}$

Within four hours these hoped- . for results began to appear. The eggs were evidently developing, and before long most of them were changed somewhat. Still only one fifth kept on developing as normal eggs of the normal frog are accustomed to do.

Moreover, as days passed, so many of them stopped growing that only I 20 turned themselves into tadpoles. This is the first great

1 Reported in Nature (London), June 22, 1911. 
transformation of frog life. Of this I 20, three lived long enough to become real frogs, while one hundred and seventeen died by accident or because they could not get the right sort of food after their legs appeared.

The oldest of the three lived three months. He had all four legs, and everything was complete about him except that his tadpole tail did not fully disappear. Then he too died. But the surprise was that any lived at all.

A record of this kind startles every biologist, because nothing of the sort is found anywhere in the ordinary history of vertebrates. What we learn from biological history is that every descendant of every vertebrate begins its individual existence by the union of two germ cells, each of which is derived from a separate individual of different sex. We learn that unless this union takes place there can by no possibility be a second generation.

Aside from vertebrates, however, there are other living creatures to whom this law of two starting cells

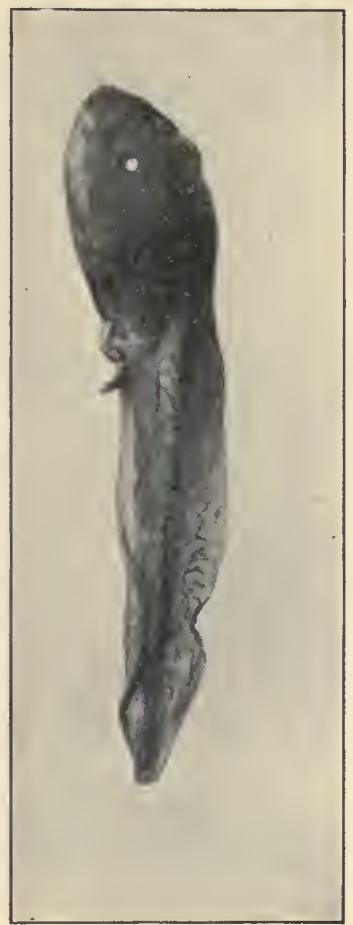

TADPOLE No. 2

This also grew from an unfertilized egg that had been pricked with a platinum needle. It died after six months with rudimentary legs only. (Courtesy of Professor Loeb) does not apply. The amœba, for example, shows quite another method. Here we have a one-celled creature that multiplies by pulling itself in two. I'o-day each amœba that lives 


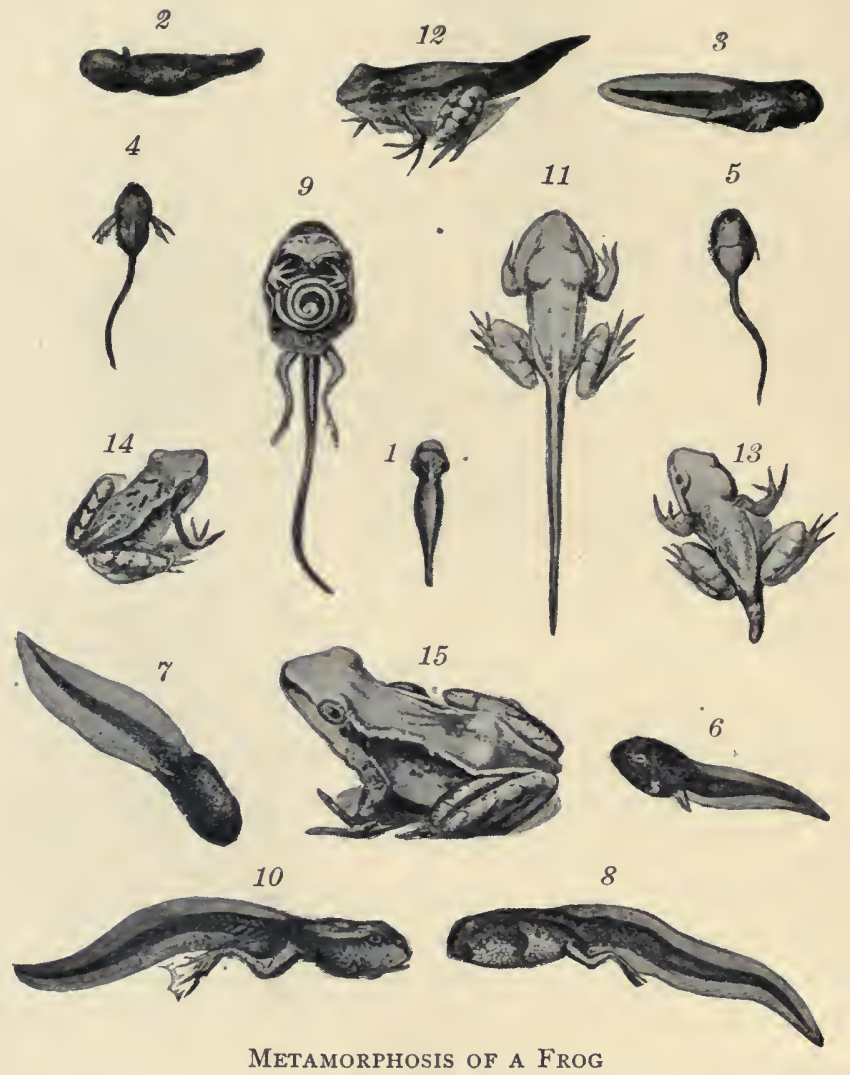

I, tadpole just hatched; 2, 3, successively older tadpoles seen from one side; 4 , a slightly older tadpole seen from the dorsal side; 5 , a still older specimen from below; 6 , tadpole with the gills covered, leaving only a small opening on the left side; 7 , indications of hind legs; 8 and Io, successively older stages; 9 , specimen with the ventral body wall removed, showing the coiled intestine and gills; I I, both pairs of legs free; $12,1_{3}, I_{4}$, successive stages in the resorption of the tail ; 15, adult frog. (After Leuckart and Nitsche.) (From "Synoptic Text Book of Zoölogy," by Weyss) 
and eats and moves about and divides is merely half of another amœba precisely like itself. ${ }^{1}$

But with fish and fowl and with all other vertebrates, including man, a new order steps in. Instead of having but one cell of protoplasm apiece, like the amoba, all complex animals are great bundles of millions of cells, and a separate set takes charge of each separate function of the body.

Through our brain cells we do our thinking and our deciding ; nerve cells do the telegraphing for us; muscle cells do the pulling; cells of liver, spleen, bone, and kidney devote themselves to work each in

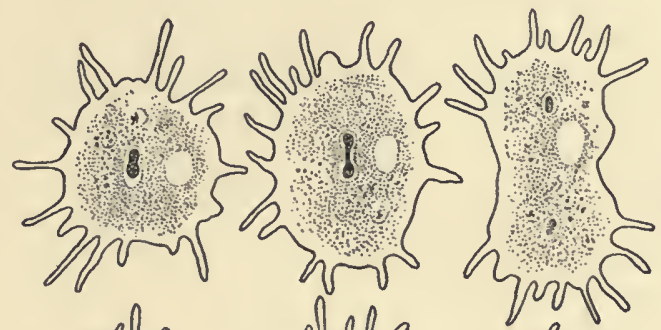
its own special

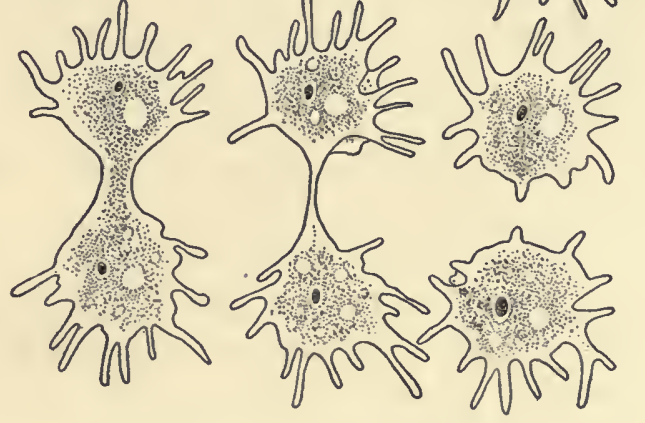

The Amceba As it Multiplies

field; while germ cells (also called gametes) are set apart for absolutely no other purpose than to carry on the life of the race. In fact they are the only bits of protoplasm in the universe that are able to pass life along from one generation to the next. They join the generations together.

1 For description of amoba see "Control of Body and Mind," of the Gulick Hygiene Series, chap. vi. 
In a certain town in Ohio, on a certain day, there were born a colt, a lamb, a puppy, and a human baby. Each one of these young animals looked and acted as all its ancestors had looked and acted when they were of the same age. We are so accustomed to marvels of this sort that we accept them as a matter of course.

Perhaps we forget that germ cells of various kinds look so much alike that no one but the keenest scientist with his strongest magnifying glass could have told beforehand which pairs of those cells were to develop into colt, lamb, puppy, and baby. Nevertheless, lodged within the cells themselves, before they began to develop, were all the different characters that were to belong to each one of the four small creatures. And these different characters represented different ancestors all the way back to the beginning of things. Size and shape, color and character, texture of wool and of hair, brain power and muscle power, keenness of vision and of scent, structure of body and type of disposition - each quality of each animal was stored up for use and packed into the small compass of its own particular pair of germ cells.

All this, then, is what germ cells do as their share of the work of life. They help on the cause of the next generation.

Other cells multiply within the body and serve the body itself without reference to the next generation. Not so with germ cells; it is true that they live within the body, but it is equally true that they exist there without any reference whatever to the welfare of the body to which they belong. In no wise do they exert themselves for the maintenance of its activities. On the contrary, they are set apart; they remain in organs of their own. The sole purpose of their existence is to help construct a new member of the next generation. 
In scientific books germ cells, in quantity, are often referred to as germ plasm, and those who study the subject often speak of germ plasm as a stream of life. They say that "the individual is only the result of the unfolding of the potential powers of a bit of germ plasm," and that, "once developed, the person carries the rest of the precious material around with him to hand down to his own offspring." 1 According to this theory the present generation is the direct outcome of all the generations that have gone before. The claim, therefore, is that germ plasm is the only part of our bodies which will live as long as the race itself continues to multiply on the earth. ${ }^{2}$

In studying cells and their development it is important to remember that neither amoba nor germ cell can live after it becomes dry, and that every dry amœba ever found was a dead amœba. So it is with germ cells; the mere fact of dryness kills them. No germ cell can live and pass on the life of the race if it stays in dry surroundings. This is true of every kind of animal life, and it is interesting to see how nature manages to keep these cells moist and useful even when they belong to different kinds of creatures.

It is easy to keep fish cells from drying up, because the fish themselves live in water and lay their eggs there. But even fish have trouble in getting the next generation safely

1 As Weismann puts it, "In each development a portion of the specific germinal plasm which the parental ovum contains is not used up in the formation of the offspring, but is reserved unchanged for the formation of the germinal cells of the following generations."

2 In this discussion about evolution and about the laws of inheritance there is often great disagreement of opinion among investigators. All believe in evolution itself, but some put emphasis on one side of the subject, some on another side. Without exception, however, they are studying facts, and the wisest among them are more anxious to arrive at the truth than to establish their own individual point of view. 
launched into life. This trouble comes from the fact that every generation of germ cells for every kind of animal has to meet three conditions :

I. Two separate cells - one each from two separate animals - must unite to form each member of the next generation.

2. To live, they must be prevented from getting dry.

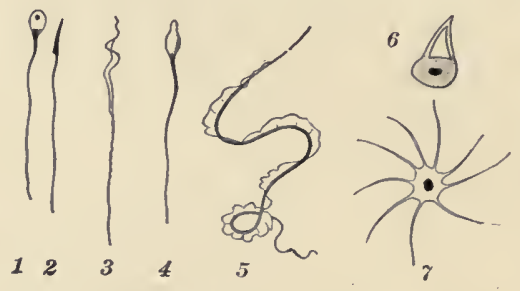

Forms of Sperm Cells (Spermatozoa) 1 and 2 , immature and mature spermatozoa of snail ; 3 , of bird ; 4 , of man ; 5 , of salamander; 6, of Ascaris ; 7, of crayfish. (Enormously magnified. Not drawn on scale.) (From Thomson)

3. They must be so placed that they will be sure to find each other.

Fish meet these conditions as follows :

The female fish, as it swims about; first deposits a mass of germ cells, each one of which is an egg - an ovum. Later the male fish, also swimming that way, deposits on the eggs a clear-looking substance which seems to resemble nothing so much as the white of an egg. This substance really contains millions of germ cells. Each one is called a sperm, and each is capable of fertilizing one of the eggs. ${ }^{1}$

It is a fairly easy matter to discover separate eggs in the vast numbers which a fish lays at one time, for they float about; looking like bits of jelly bunched together. It is otherwise with the sperm cells. All that the eye sees is a thickish liquid, but under the microscope, in the liquid itself, we see numberless darting objects that are in constant

1 A mature germ cell is often called a gamete. When two germ cells, or gametes, unite they form a fertilized cell called a zygote. 
motion. Each is a single cell -a sperm. Each seems to have both head and tail, like a stretched-out tadpole. All are so small that it takes six thousand sperm heads placed side by side to measure one inch. When they have the chance for it, each is ready to join an egg, and together they start life for a new fish. This is called fertilization.

Now in a general way this history of fish beginnings is really the history of the beginning of every vertebrate, man included. There is never any confusion in results. The individual started by fish parents becomes a fish, while birds and beasts and each separate kind of human being have children according to their kind. This law of life does not vary. It is immutable.

It is of course true that the first two cells do not always come upon one another by the same road. With fish they are deposited side by side in water. This is all that is necessary. They reach each other, and young fish begin to develop.

With birds and other animals there is another arrangement. Since the environment of creatures that do not live in water is always dry, and since germ cells must not be allowed to get dry even if they do belong to dry land animals, nature provides for this. The germ cells of these animals pass directly from one individual to another.

A further point is that germ cells which are to carry on the life of the race - whether of fish or of any other creature must stay in damp surroundings from the time they meet until the individual is formed. Nature brings this about in three different ways :

I. With fish and frogs the eggs stay in the water and develop there.

2. With birds and reptiles a stout shell is supplied. This shell grows about the germ cell within the body of the mother, 
and as it thickens, nature packs into the shell a mass of albumen - the white of the egg. This albumen does two things :

$a$. It supplies moisture for the developing cell.

$b$. It provides nourishment for the growing individual.

Moreover, the shell itself does two things :

$a$. It is of such a texture that it keeps the moisture of the albumen from evaporating even after the egg has been laid.

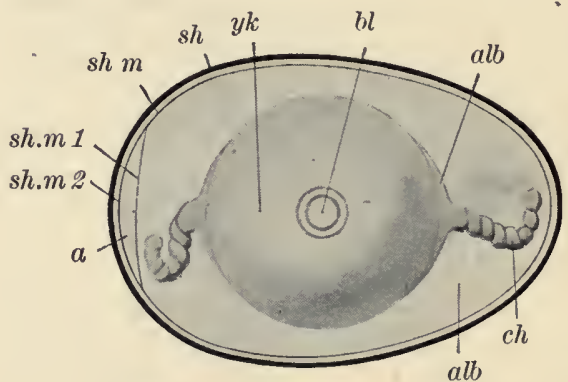

DIAGRAM OF BIRD's EgG

b. It is so porous that air gets into it for the occupant to use while it develops. ${ }^{1}$

With these facts in mind, the natural question is, Why are not all animals - ourselves among the rest - supplied with eggshells $y k$, yolk; $b l$, germ disk; $a l b$, white, or albumen; $c h$, thickened albumen which holds yolk in position; $a$, air space; sh. $m$, two shell membranes; sh, shell.

(From Parker and Haswell)

and then hatched out when the time comes? The answer is that when the growing animal is to be small, it is comparatively easy for nature to arrange to have it spend its first stage of growing within an eggshell, but when an animal is to be so large that it must develop for months instead of weeks before it is ready for the outside world, then nature has to make some other arrangement; that is, no egg can be planned for big enough

1 After an egg has been fertilized and laid, it must be kept at a definite temperature for a definite length of time. Hens and birds keep their eggs warm enough by sitting on them. Incubators have to supply the same temperature, else the eggs will not hatch. Each kind of egg has its own time limit for hatching. 
to hold all the nourishment that will be needed for months of growth within a shell. For such cases nature has its third device.

3. Instead of surrounding the germ cell with the white of an egg for moisture and food, instead of supplying a shell to keep the moisture in and to protect the whole from harm, instead of sending the germ cell away from the body to develop by outside heat, nature sees to it that the fertilized cell stays within the body in a soft covering of its own. Here it is both warm and moist. Here it develops until it is able to continue its growth in the outside world. And while it develops, the wonders of life and of growth reveal themselves.

Dr. Minot's facts about growth read like a fairy tale. A few of these facts are given in the next chapter. 


\section{CHAPTER XVI}

\section{THE MARVEL OF GROWTH}

Dr. Minot studied chicks from the time they began to develop within the eggshell until the last bit of down was laid in place, until the shell was packed to its utmost limit with a living chick, until hatching time had come. To do this he took eggs that were set for hatching, broke one on each successive day, and examined the contents both with the microscope and with the naked eye.

$\mathrm{He}$ also took frequent photographs of the progress of these developing chicks. In this way he followed them step by step as the bundles of the cells grew bigger, and we have the printed record of what he found.

First day, "A mere gathering of cells."

Second day, "The chick has distinctly a head and a little heart."

Third day, "The eye has developed, the heart has become large, the tail is projecting, the dorsal curve of the future neck is distinguishable."

Fourth day, "It is a strange-looking beast, with a wing here and a leg there, a little tail at this point, an enormous eye, almost monstrous in proportion, and, finally, a great bulge caused by the middle division of the brain."

Fifth day, "We now have a chick the brain of which is swelling, causing the head to be of so queer a shape, with the eye that seems all out of proportion to the rest of the body, that it imparts an uncanny look to the embryo. The 
wing is showing itself somewhat, and the ends of the leg, we can see, will by expansion.form the foot."

After ten full days of growing we have a chick with feathers beginning to grow over the entire body. Within those ten days the two germ cells which joined to form the beginnings of the chick have multiplied themselves into this

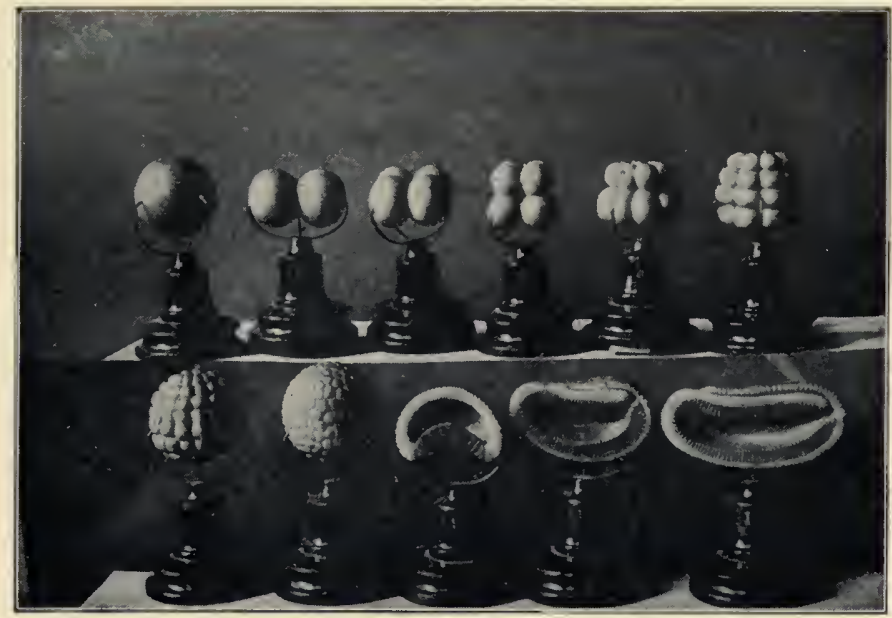

Eleven Steps in the Early Growth of an Embryo

From a photograph of a set of models, showing each cell enormously magnified. The last three models are of cross sections and indicate how the layers are being formed

astonishing result. Never again in later life does any chick increase in size with such surprising speed as is shown by the growing embryo of this oviparous ${ }^{1}$ animal.

The special point to bear in mind is that, from start to finish, this whole process of growing is nothing more nor less than the dividing and the subdividing of the two germ cells which were joined as one. This first combination cell

${ }^{1}$ Animals developed from an egg are called oviparous. 
became two; the two became four; the four, eight. Then there were sixteen, thirty-two, sixty-four - the total number doubling about once every hour. And this is the way every embryo begins to grow.

But, strange to say, although, when born, each different kind of animal is to look so different from all others, this difference does not show itself in the earliest stages of the different embryos. On the contrary, among vertebrates, differrent embryos in their earliest stages look so much alike that often even an experienced biologist is hardly able to distinguish fish from salamander or rabbit from man.

For days and weeks, however, the multiplication of cells goes on steadily, never ceasing, and even before birth the time comes at last when each creature declares what it is by its shape of body, legs, and head.

In the meantime the animal must have nourishment if it is to grow, and nature supplies it. Animals in eggshells get their first food from the yolk and then from the white of egg that surrounds the yolk. But when the yolk supply is exhausted, and when the white part is consumed by the cells as they multiply, then it is that the expanding chick has to strike for freedom and for a new environment. The time has come when he must have more food and more room to grow in. He finds neither the one nor the other within his eggshell.

Twenty-one days after the hen begins to sit on her eggs, or an incubator begins to warm them, some instinct within the chick tells it to peck at its shell and make its way out into the world. The instinct is obeyed, and out steps a damp little creature, as perfect as a chick can ever be. Those three weeks have been long enough for multiplying cells to turn themselves into head and feet and claws, down and muscle, brain and nervous system, and every other minutest part of 
the marvelous structure that toddles about on its two feet and begins to peck at bits of straw and kernels of grain.

Other animals also have their rate for rapid growing. But before going farther, four or five statements must be made.

I. Vertebrates are either oviparous, that is, developed from an egg and hatched outside the body of the parent, or viviparous, developed within the body of the parent and born alive.

2. All mammals, except the duckbills of Australia, are viviparous.

3. Whether it is oviparous or viviparous, any developing creature is called an embryo until it is hatched or born, as the case may be.

4. Before birth oviparous animals receive their nourishment from food which is stored within the eggshell, while viviparous animals receive their prenatal nourishment from the mother herself. It reaches them through a tubelike cord which joins the embryo to its parent. At the outset this cord is a mere thread, but it grows stronger and stouter as the cells of the embryo multiply and as the developing creature grows heavier and larger from day to day.

5. It takes twenty-one days for a chick to develop in its shell. A duck develops in four weeks, a guinea pig in twentyone days, rabbits and squirrels in thirty days, while for cats it is sixty-five days, for dogs sixty-two, for a lion three months, for a pig four months, for sheep and goats five months, for a bear six months, for a cow nine months, for a human baby nine months, for a whale ten months, for a giraffe fourteen months, and for an elephant twenty-one months.

Notice that in general the time needed for development is in proportion to the size which the developing creature is to attain in the end. Yet in every case the starting point is always the same - no more than two germ cells for either 
the whale or the elephant, and no less than two cells for either the mouse or the mosquito.

In this connection remember that never in the life of any animal do cells multiply so fast as before the creature is born. And this applies equally well to viviparous and to oviparous

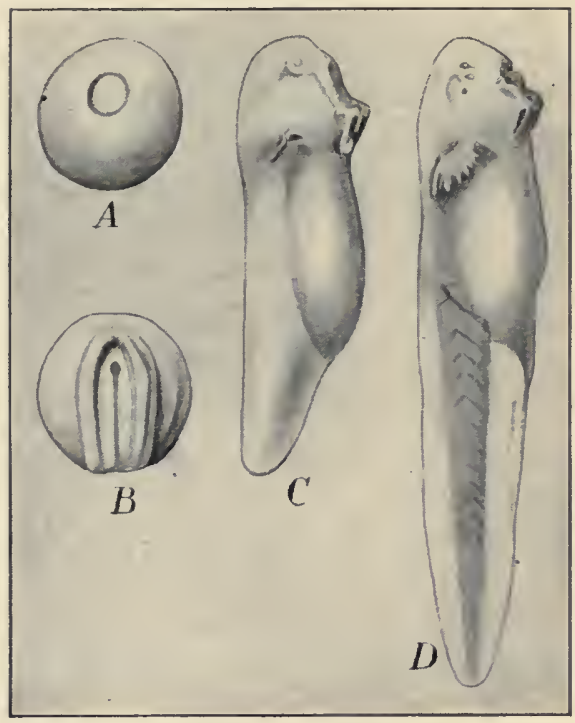

Four Tadpoles of the European Frog (RANA FUSCA)

The four animals are all of the same age (three days). They were raised from the same batch of eggs but have been kept at different temperatures. (After Oskar Hertwig) animals. But after birth, what a difference! Compare, for example, the chick and the rabbit. The former is spry from the start. He has keen, round eyes. He spies food at once, seizes it, feeds himself, and scurries about on sturdy little legs, apparently having a mind of his own from the first. Fluffy down covers his body, and in summer, when chicks are young, the warmth of a sheltering mother often seems altogether superfluous.

It is otherwise with the viviparous small rabbit. $\mathrm{He}$ arrives in the world blind, almost naked of hair, unable to move in this direction or that, unable to hunt for food, able indeed to do nothing more than take food from his mother according as he needs it. 
These two creatures, the chick and the rabbit, are good illustrations of the difference between some oviparous and many viviparous animals. But, for both alike, surroundings make all the difference in the world in their after life. If they have too little food or unfit food, if their environment is too hot or too cold, too wet or too dry, they will not grow as they should.

For example, Dr. Minot reports the effect of temperature on the development of tadpoles. Four were taken from the same set of eggs, and each was kept in water of a different temperature. The illustration shows the result. The one marked $D$ was kept so warm and comfortable that the multiplying cells did their best. After three days he was a lusty young fellow of goodly size and shape. $A$ was kept so cold that he barely lived. The result is evident. His cells were so chilled that they could not multiply normally.

These and other experiments prove that, from the beginning, the condition of the environment vitally affects the development of the individual. When this environment is right, the development is rapid and normal; when it is wrong, the development is sure to be abnormal.

Dr. Minot tells us that in the first year of its life a normal seven-pound baby gains 200 per cent, and will weigh 2 I pounds by the end of the year. In the second year he will gain 20 per cent, and after that about Io per cent each year until he is fourteen years old. Dr. Minot also pictures the growing baby and shows that never afterwards does any human being learn so much or grow so fast as during its first eventful year after birth. Two things it can do from the start: it can take nourishment, and it can thrash its arms and legs about aimlessly. Comparatively soon, also, it gains the powers of touch, hearing, sight, taste, and smell. Through these five roads 
information pours in upon the baby, and by the end of one month he has learned that certain sensations are pleasant and certain other sensations unpleasant. He fastens his eyes on this or that and stares without winking. How babies stare!

After two months he has learned to expect definite things at definite times. Three months, and the baby has learned that he can so guide his muscles as to accomplish definite movements. This is a very great discovery. He seizes his own toes. He clutches other things and pulls them. At the fourth month he finds he can really do things. He shows purpose. "His movements are no" longer purely accidental. ... At four months he discovers that the face and the back of the head belong to the same object. He has acquired the idea of objects existing in the world around him. He has no instructor. He is finding out these things by his own unaided efforts. Then, at five months, begins the age of handling, when the baby feels of everything." The first five months, as Dr. Minot says, "constitute the first period of the baby's development. Its powers are formed and the foundations of knowledge have been laid. The second period is a period of amazing research, constant, uninterrupted, untiring, renewed the instant the baby wakes up, and kept up until sleep overtakes it. In the six-months baby we find already the notion of cause and effect."

Dr. Minot's description grows more and more vivid. "By eight months the baby is upon the full career of experiment and observation. Everything with which he comes in contact interests him. He looks at it, he seizes hold of it, tries to pull it to pieces, studies its texture, its tensile strength, and every other quality it possesses. Not satisfied with this, he will turn and apply his tongue to it, putting it in his mouth for the purpose of finding out if it has a taste. At 
the same time he is making further experiments with his own body. He begins to tumble about, perhaps learns that it is possible to get from one place to another by rolling or creeping, and slowly he discovers the possibility of locomotion, which you know by the end of the year will have so far perfected itself that usually at twelve months the baby can walk."

Dr. Minot goes on to say that if conditions are favorable during these early months, the later development of the child will be greatly advanced. "In brief," he says, "I find myself led to the hypothesis that the better health of the mothers secures improved nourishment in the early stages of the offspring, and that the maternal vigor is at least one important cause of the physical betterment of the children."

This chapter on growth and the preceding chapter on germ cells make it plain that the welfare of the cell itself is of utmost importance to the individual that develops from the cell. Imagine, then, what the result might be if something in the blood could reach germ cells and damage them before they begin to multiply in growing.

The next chapter gives facts instead of imaginings concerning this very subject. 


\section{CHAPTER XVII}

\section{GERM CELLS DAMAGED BY ALCOHOL}

On the fifth of December, I9I I, there appeared an article in a German paper, written by Dr. Forel. ${ }^{1}$ This article discusses germ cells and gives an interesting account of certain hens' eggs and their hatching.

It seems that 160 eggs were in an incubator in a shed, ready to be hatched. All were due to hatch the same day, but when they appeared, instead of straight-legged, wellshaped little creatures, every third chick that pecked its way into the world had either crooked legs, useless wings, a twisted back, or some other deformity. Moreover, instead of 160 chicks, only 78 were hatched, and this included every deformed one. The rest died in their shells, not having vigor enough to make their way out. Worse yet, instead of keeping alive after they were fairly hatched, 40 of the chicks died within four days.

Such a record as this has to be explained somehow, and those who studied the case searched surrounding conditions. Dr. Forel reports results. He says the investigators found that the shed where the incubator was kept had a cellar to it, that the owner of the eggs used this cellar as a distillery, and that while the chicks were developing in their shells the man had kept his distillery busy making brandy.

1 Printed in the Münchener, medizinische Wochenschrift, December 5 , I9II. 
By putting two and two together the men came to this conclusion: "The distillery and its alcohol in the cellar killed some of the chicks before they were hatched, killed others after they were hatched, and deformed all the misshapen ones that we see about us." Dr. Forel's conclusion was that even the fumes of alcohol have power to damage germ cells while they are turning into living creatures. No one questioned the statement for a moment. It is indeed quite in line with what Dr. Féré discovered between the years I894 and 1903 .

He carried on two sets of tests with hens' eggs. All the eggs were hatched in incubators. On one set he put váporized alcohol ; the other set was left alone. He repeated this experiment many times, and the results were always the same. Eggs that were not reached by alcoholic vapor hatched out into the usual number of healthy chicks with minds ready for active service. Eggs treated with the alcoholic vapor produced many deformed chicks that had no minds whatever. They ranked among chicks as idiots rank among men. They had no mental power to guide their lives by.

Guinea pigs also add a proof or two in this direction. Dr. Stockard was the investigator. ${ }^{1} \mathrm{He}$ says that at first he gave the guinea pigs alcohol with their food, but they disliked it and ate less food. Next he put alcohol into the stomach through a tube, but this distressed the animals, and he was afraid it might do them harm.

Then came his final device. He made air-tight copper tanks that were a yard long, a foot high, and eighteen inches wide. The tanks had wire-screen floors, and under the floors he put cotton soaked in alcohol. The alcohol evaporated up into the

1 See Archives of Internal Medicine, October, 1912, "Experimental Study of Racial Degeneration in Mammals treated with Alcohol." 
tank until "the atmosphere was saturated with the alcoholic fumes." The place was then ready for the expected occupants.

After this, as he says, "the guinea pigs, three or four at a time, are placed on the wire screen above the evaporating alcohol, the tank is closed and the animals are allowed to remain until they begin to show signs of intoxication, though

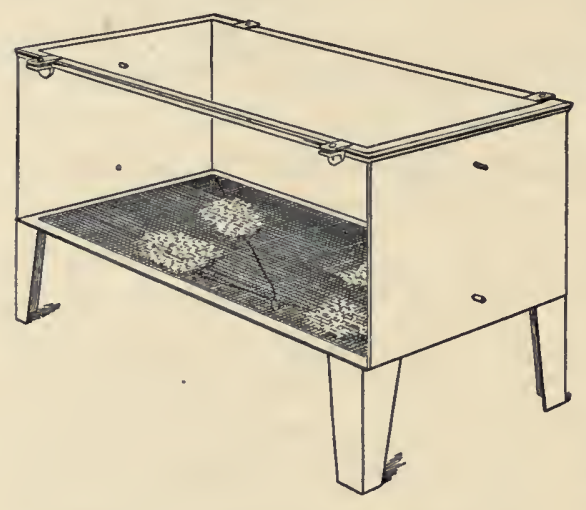

Copper TANK USEd in Dr. Stockard's AlCOHOL EXPERIMENTS

Notice the light-colored sponges under the wire netting of the floor. Alcohol evaporated from the sponges into the tank they are never completely intoxicated. They usually inhale the fumes about an hour."

During all the rest of the time, day and night, the guinea pigs breathed air entirely unmixed withalcohol. This was the treatment they received for six days in every week, and it was kept up for nineteen months - with what results, we wonder.

At first the fumes troubled them. It made their "eyes water until tears ran over their faces." Dr. Stockard says : "The majority of them sit quite motionless and sniff their noses for a time and then become somewhat drowsy." A few, however, "are excited by the treatment, and run about the tank, and many often fight other animals savagely."

But in the course of several weeks they were not even uncomfortable in the tanks. They seemed to take the fumes as a matter of course, appeared healthy, and even gained flesh. 
But what about the next generation during those nineteen months? Certain classified results answer this question.

There were four kinds of tests :

I. The paternal test - when the father was alcoholic, the mother normal.

2. The maternal test - when the mother was alcoholic, the father normal.

3. The double test - when both parents were alcoholic.

4. The normal test - when neither parent had endured alcoholic fumes.

The table shows what happened to the next generation in each of these cases.

Alcohol Tests

\begin{tabular}{|c|c|c|c|c|c|c|}
\hline $\begin{array}{r}\text { Condition of } \\
\text { Animals }\end{array}$ & & $\begin{array}{c}\text { TOTAL NUM- } \\
\text { BER BEFORE } \\
\text { BIRTH }\end{array}$ & $\begin{array}{c}\text { BORN BE- } \\
\text { FORE FULIY } \\
\text { FORMED }\end{array}$ & $\begin{array}{c}\text { Died AT } \\
\text { BIRTH }\end{array}$ & $\begin{array}{c}\text { DIED SOON } \\
\text { AFTER. BIRTH }\end{array}$ & $\begin{array}{c}\text { NUMBER } \\
\text { THAT LIVED }\end{array}$ \\
\hline Paternal test & . . & 34 & I 4 & 8 & 7. & 5 \\
\hline Maternal test & . . & 6 & I & o & 3 & 2 \\
\hline Double test . & . & 17 & IO & 6 & I & 0 \\
\hline Normal test . & . & 17 & o & 0 & o & 17 \\
\hline
\end{tabular}

Here we see, by the last column, that when neither of the guinea-pig parents was subjected to the influence of alcohol, all seventeen children lived; and that when both parents were affected by alcohol (see the double test), ten children were born before they were fully formed, six died at birth and one after birth, while none lived.

These experiments leave no question as to the effect of alcohol on the descendants of chickens and guinea pigs. But our special interest is with human beings. In Philadelphia, Dr. Gordon studied I 8 families where both father and mother used alcohol. In these families there were 200 children. Of these children 150 were epileptics. He also studied 20 
families where the grandfather as well as the parents used alcohol. Here he found 26 imbecile children and 38 who were lunatics, while every one of the others was defective in one way or another.

In Bern, Switzerland, Dr. Demme looked up the history of ten families that drank and ten families that did not drink. Study the record and see what happened to the next generation of those that drank.

Record of Ten Drinking and Ten Abstaining Families

\begin{tabular}{l|c|c|c|c|c}
\hline \hline & $\begin{array}{c}\text { Number of } \\
\text { Children }\end{array}$ & $\begin{array}{c}\text { Difd in } \\
\text { 1Nfancy }\end{array}$ & $\begin{array}{c}\text { 1diotic, Epileptic, Deformed, } \\
\text { Serious Nervous Trouble }\end{array}$ & Normat, \\
\cline { 2 - 6 } Drinking families & 57 & 12 & 36 & 9 \\
Abstaining families & $6 \mathrm{I}$ & 5 & 6 & 50 \\
\hline \hline
\end{tabular}

With facts piling up in this way, investigators have kept asking themselves just when and how the alcohol of the fathers most affects the children.

When Dr. Bezzola tried to answer this question he was house physician in an institution for weak-minded children in Switzerland. Here he noticed that almost always, when weak-minded children were brought in to be cared for, some one would say, "His father was a notorious drinker." To see how much truth there was in this, Dr. Bezzola determined to learn what the facts really were. ${ }^{1}$

He took the latest census report available (I880-1890) and found that during those ten years 934,63 I babies had been born in Switzerland. He also found what the average number of births was for each month of the year, and discovered

1 See publication by Dr. D. Bezzola, printed in German: "Statistische Untersuchungen über die Rolle des Alkohols bei der Entstehung des originären Schwachsinns." 
that in some months the proportion of idiots born was much larger than in other months. This was quite a clue.

Next he looked up the life history of 8196 feeble-minded persons who lived in Swiss asylums, and made note of the birthday of each one of them. He wished to know when the children were born, so that he could count backwards forty weeks ${ }^{1}$ and find out just when the babies began to develop from germ cells. He thought this might show him what the condition of the parents was at the time.

$\mathrm{He}$ tells us that in Switzerland there are certain definite seasons each year when what he calls "drink-festivities" are most abundant - New Year's and carnival, the vintage and the harvest seasons. Dr. Bezzola speaks of these as alcoholrich periods.

From July to September, however, wealthy people and poor people alike are drinking less. They are busy with summer travelers and summer occupations ; they keep regular hours with fewer festivities. These are the alcohol-poor months.

With his facts in mind Dr. Bezzola turned to the birthdays again. His chart of results is given on the next page.

Follow the lines from left to right. Notice how they move up during certain months and down during other months. By understanding this chart we are able to understand the substance of the report which Dr. Bezzola made.

I. When alcohol festivities are most abundant in Switzerland, the largest proportion of weak-minded children receive the gift of life. What is true of Switzerland is no doubt equally true everywhere else in the world.

2. In large numbers of cases alcohol and weak-mindedness stand together as cause and effect.

1 Time needed for a baby to develop from two germ cells. See last chapter. 
Sept. Oct. Nov. Apr. May Dec. Jan. Feb. Mar. June July Aug.

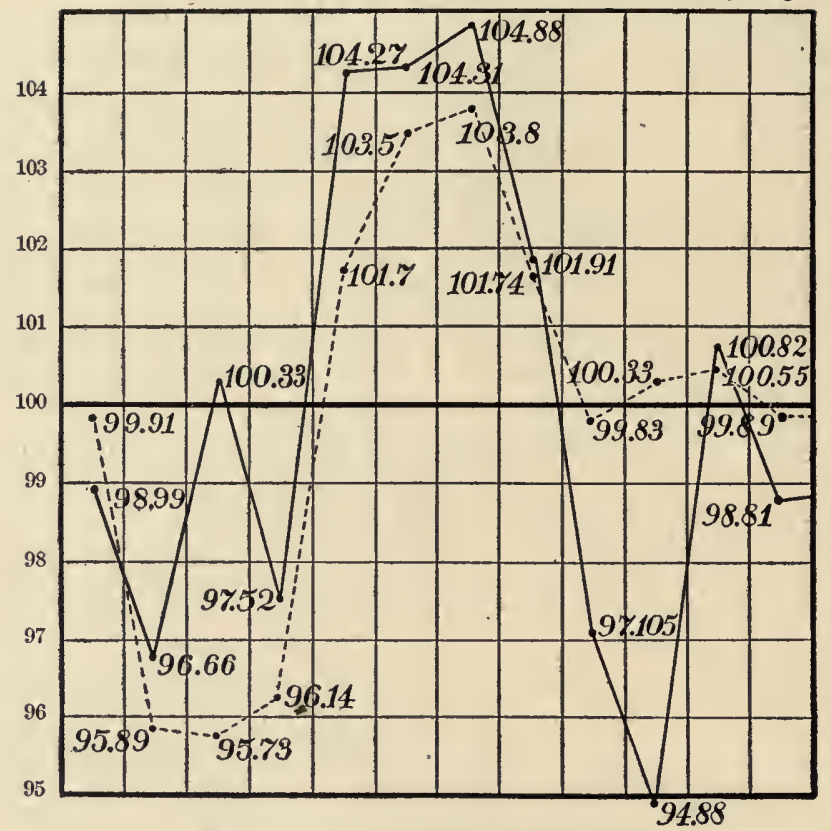

\section{Alcohol and FeEble-mindedness}

I. The dark line through the center represents the daily average number of births for the year as a whole.

2. The black points in the squares below the name of each month indicate the daily average of births for that particular month.

3. The black points on the dotted line indicate the average number of nomal persons born during each month.

4. The black points on the solid black line indicate the average number of feebleminded persons born during each month.

5. Count backward nine months from each point to discover the month of conception for both sets of persons.

6. Studied in connection with each other, the dotted and the solid lines show that there are certain months of the year when the (daily) average of births is high, both for normal and for feeble-minded persons. In addition, the solid line shows that the average for feeble-minded persons rises unusually high and falls unusually low according as the months in which the individuals started to grow are alcoholrich or alcohol-poor. For example, notice that the average number of feeble-minded persons born in January, February, and March is very high, and remember that the alcohol-rich period of April, May, and June came nine months earlier. Also notice that the average number of feeble-minded persons born in May and June is very low, and remember that the alcohol-poor months of August and September came nine months before. (From Dr. Bezzola's Chart) 
It is true that many drinkers have intelligent children, but, as Dr. Bezzola says again, "These people were free from too much alcohol at the time the new life was started."

No one can ever tell just how much alcohol a person may take without damaging a future child, but Dr. Bezzola declares that "the time may come when we shall see that every drop of alcohol taken by the parent means a drop of stupidity for the child."

From other studies which he made Dr. Bezzola came to the conclusion that germ cells themselves may be damaged when alcohol enters the blood stream, and that human beings who develop from such damaged cells are doomed from the start.

Future investigations will show whether or not alcohol is entirely to blame. In the meantime we are interested in such studies because they show that alcohol which ancestors use, seems to curse numberless descendants in body or mind, or in both. The worst of it is that the curse is liable to be passed on even though these descendants do not themselves use alcohol.

Never blame any weak-minded person. Remember that he cannot help himself, and remember that probably his parents injured him through ignorance. Be thankful that your ancestors stamped you aright. Be thankful also that you have grown up as a normal human being, and that you are able to understand something about the marvel of growth which changes vigorous germ cells into well-developed chicks and children.

After the earliest years of growing are over, the next -most important era of life lies between the ages of fourteen and twenty. This period is the borderland between childhood and maturity. 


\section{CHAPTER XVIII \\ FROM FOURTEEN TO TWENTY}

In I 897, for the sake of gathering facts, Dr. Luther $\mathrm{H}$. Gulick wrote a letter in which he asked a large group of men

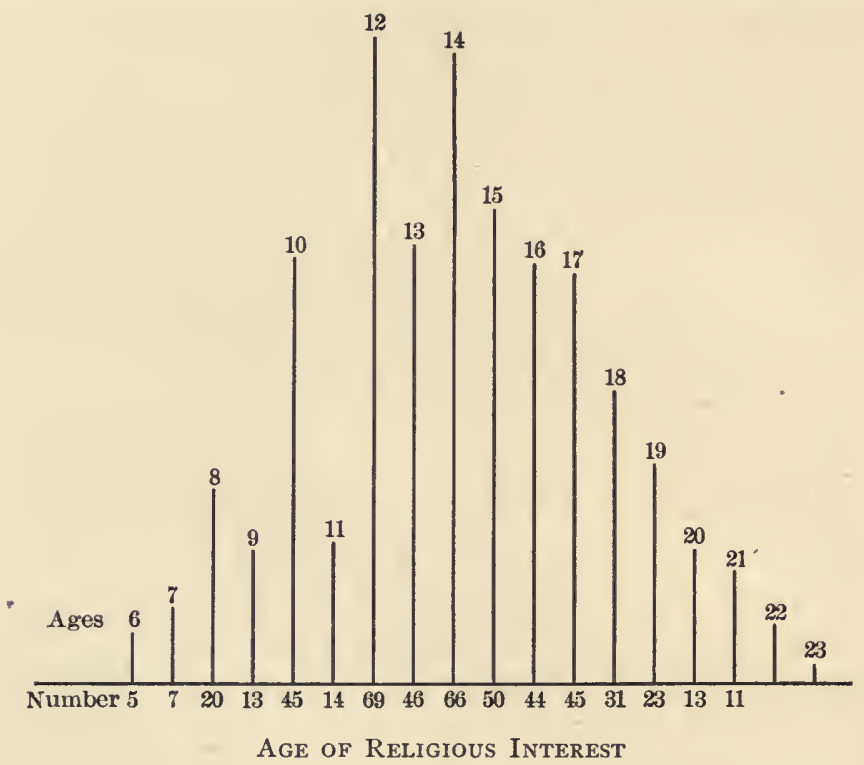

certain definite questions. Among these questions were the, following:

I. At what age were you first deeply affected by religious influences?

2. At what age did you become a Christian? 
3. At what age did you unite with the Church ?

A copy of his letter was sent to the general secretary of each Young Men's Christian Association in the United States and in Canada.

Five hundred and ninety answers came back. Dr. Gulick studied these carefully, put all answers of the same kind to-

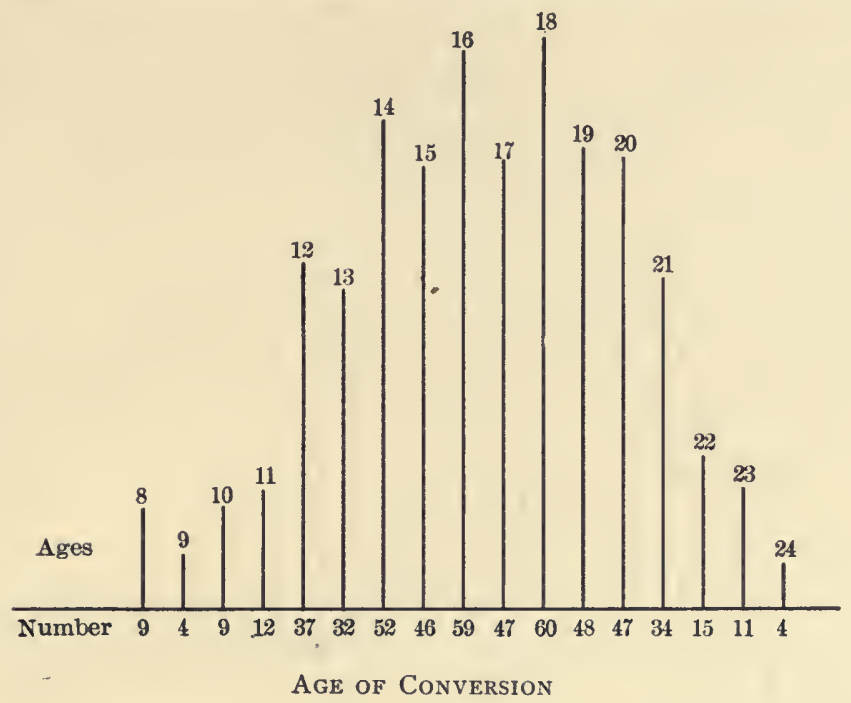

gether, made out tables of classified figures, and printed them for the benefit of other investigators. He was as surprised as any one at what he found.

The tables showed that in the vast majority of cases the one special choice which turned the lives of the men upward instead of downward was made between the ages of fourteen and twenty. Since such tables are even more interesting to young people than to their elders, they are given here in full. 
Other tables illustrate the same point. Mr. Starbuck gathered material and made out charts both for men and for women. These show the same general facts which Dr. Gulick brought out. They also show that in general girls made decisions at an earlier age than boys did. This is because young girls are usually more mature than boys of the same age.

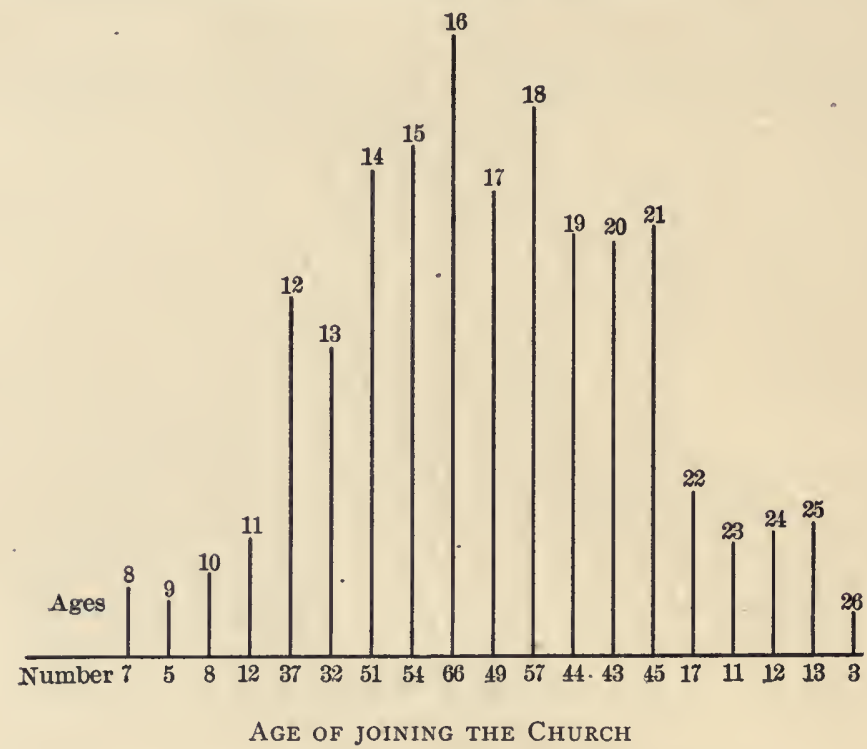

There are also tables of choices of another sort. Dr. Gulick studied the report on crime and pauperism, given in the Eleventh Census of the United States. From this report he made another set of statistical tables.

These show that the average age of those who were-in prison at the time the reports were made out was twentythree years. Now this is so much older than the period of conversion given in the previous tables, that we wonder if 
decisions for evil are made later in life than those for good. Dr. Gulick says the reports do not show when the men were put in prison, but that the "average length of a man's sentence to prison in America is 4.07 years," and that we may assume that, on the average, half of the sentence of these men had expired. This "would make the average on entering prison, of the maximum, group, twenty-one instead of twenty-three years." Then he adds, "If now we could find the age at which these individuals were committed to prison for their first crime, it would be much younger yet, but this is impossible and must be left to conjecture." He closes by saying, "The tremendous fact remains that more individuals take to criminal life at twenty or under than at any or all other periods of life combined." His claim indeed is that first decisions, both for good and for evil, fall within the adolescent period. What is this period? we ask. What are the signs and symptoms of it? Since knowledge leads to self-control, the following facts are important.

In all forms of life the time is sure to come when a great change transforms the outlook of things for each individual. $\mathrm{Up}$ to this point the body has been growing continuously. It has taken nourishment, has developed after the fashion of its ancestors, has been influenced by its environment, and has become vigorous or frail according as the conditions of food and of health have favored or hindered its development.

Each step of this process goes on for a definite length of time. But it is all mere preparation, for at the end of it every creature that survives childhood enters on what proves to be the most significant era in its history.

Until the dawn of this new era, mature germ cells are not found in the growing body. Now, however, the special material which has been there since birth, becomes active, and 


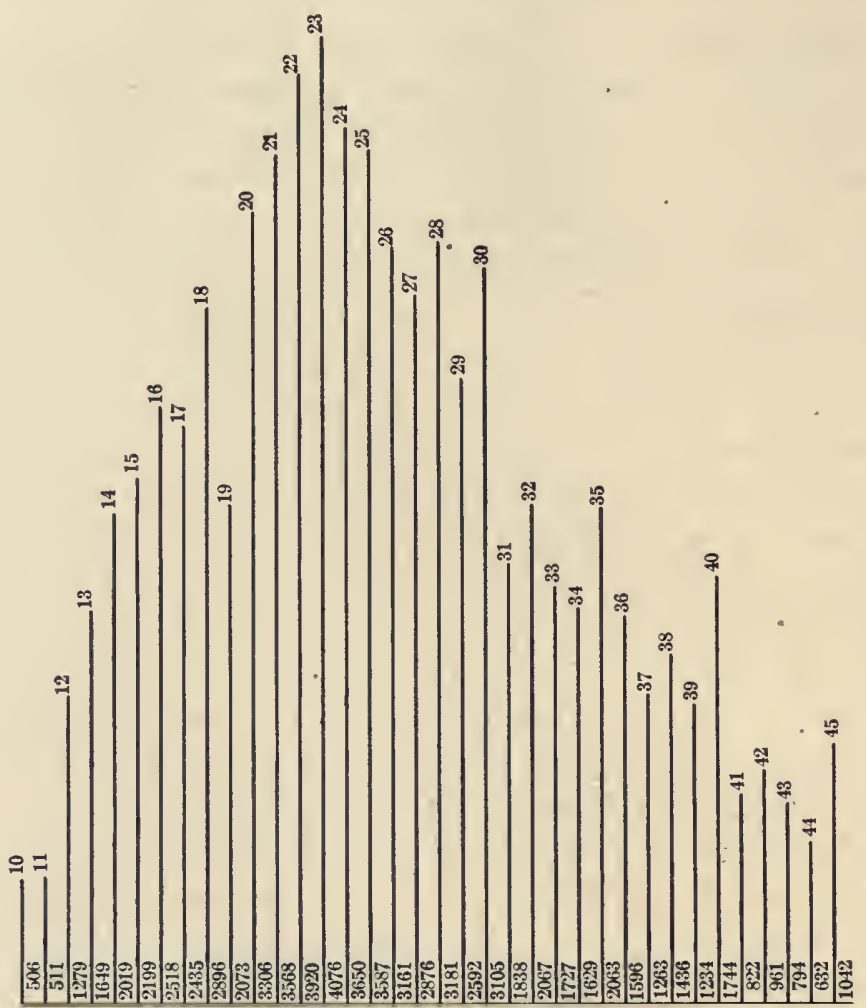

\section{AGE OF IMPRISONMENT}

Scale, 1000 to the inch. This table shows the total number of criminals for each year who were between the ages of ten and forty-five years. Both prisoners and inmates of reformatory institutions were included. The upright lines indicate the ages. The figures at the bottom, between the lines, indicate the number of persons of the given age; that is, there were 506 who were ten years old, 5 I I who were eleven years old, etc.

the body, as it develops in new directions, accommodates its growing to the demands which germ cells place upon it.

For human beings no period of life is more full of fateful import than the years between fourteen and twenty. When 
the era opens, the person is a simple child with childish thoughts, childish interests and ambitions. When the era ends, the person has become a man with his greatest decisions of life already made, with the destiny of the rest of his life practically settled. And this spiritual development goes parallel with a development of the body.

Each organ, bone, and muscle now speeds its growing. Arms and legs stretch out so far that sometimes they seem altogether too long. For boys the shoulders broaden, the back grows stronger, the jaw is firmer, the biceps and other muscles grow bigger. In every physical direction of height, weight, and strength, the body clearly indicates that it is preparing for maturity.

All these changes are, in point of fact, the physical gateway to manhood. Nature is developing a man, the highest product of evolution, one who will become the ancestor of others like himself.

The transformation is just as real for a girl. Her form grows rounder; her voice becomes sweeter and richer. Everything points to maturity. Her cells too are preparing themselves for a next generation.

In the meantime, for boys and girls alike, the emotional nature keeps step with the physical. Every sense grows more keen, more alert. New sensations are at hand, new ambitions, new hopes, new fears. Some are so intense that the youth hardly knows himself, while imagination seems to lead the way with a flaming torch. Nothing is beyond its reach.

Boys now read tales of great adventure and count themselves the equal of the heroes. They study science with enthusiasm. Machinery of every sort fascinates them-wireless telegraphy and the telephone, steam engines, and the aëroplane. They wish to know where life comes from, what 
it really is, and what relation the generations of the past bear to those of the future. It is just now that passions become strong. It is during these years that boys meet some of the great temptations of life. If they can keep their craft steady as it whirls through the adolescent years, they may be trusted to guide it safely thereafter.

On every side great subjects appeal to the imagination and spread themselves before the eager gaze of boys who first really begin to grasp the splendor of life during their years of rapid change. At the same time these boys grow so fast that hands and feet seem to be in the way. They are awkward in the presence of older people and of girls. They begin to shave and to think more about their personal appearance. They wish to do such things as seem most manly.

It is during this period that many boys, if they are ignorant of scientific facts about tobacco, begin to smoke. They do this innocently, not knowing about the harm which may follow. They take to smoking not because the odor or the taste or the sight of tobacco pleases them, but simply because just now smoking seems to them a great and manly deed. The mere fact that a boy begins to smoke in his teens shows that he is passing through the period of life when he wishes to be counted manly. Almost unconsciously he aims for the admiration of his fellows. Sometimes he is even lawless for the same reason.

Friends who watch the changing boy wait anxiously for the outcome. Sometimes he himself is perplexed. He should be told that, whether he wills it so or not, he himself is the prophet of his own future. He must know that while imagination and ambition have their hold on the rudder of his craft, self-control and will power stand there, too. He must 
not forget that, for good or for evil, character develops as fast as cells multiply, and that, by his own choosing, he himself decides what the nature of his character development shall be.

During this adolescent period girls find themselves more self-conscious than formerly, more subject to the blues, more given to reverie, more critical of themselves and others. Often they are shy and awkward, while at the.same time some of them giggle at everything and at nothing. In fact giggling is one of the symptoms of their shyness. They begin to think more about their clothes, their looks, and their manners, and about boys and what will please them. Some girls become unexpectedly forward; others find themselves sensitive and tearful - so much so that their parents and friends sigh and exclaim, "What in the world is the matter with her ? She does n't seem at all like herself lately."

Let no one worry, least of all the girl herself. The period of change will come to an end; and after a while she will lose whatever she may now have of unusual boldness or of awkwardness, of shyness, of giggles, or of tears. For, despite them all, even now she grows constantly more attractive in appearance and more winsome in manner. She is becoming more womanly and gracious day by day. She cares more for the welfare of others, feels more sympathy for those who suffer, grows ambitious to excel in all lines of endeavor, sometimes takes the highest rank in her classes, is in danger of living under high nervous pressure, and must be protected against herself by those to whom she is dearest.

It is during these same years that girls dream daydreams and are tempted to overdo the reading of fiction. Much reading of this kind is harmful, because it abnormally stimulates the imagination and the emotions. Girls as well as boys meet 
strong temptations during these years; girls as well as boys make or mar their future by the decisions made just now.

Indeed, no transformation of chrysalis into butterfly is ever more wonderful than this change of human beings from childhood to manhood and womanhood. It is therefore essential that those who pass through the transformation should have no false notions about it. For some the change comes earlier, for some later; for some one kind of temptation is strongest, for others another kind of temptation. But, whether one experience comes or another, whether life turns this way or that, the adolescent era and all that goes with it is part of the universal life of humanity, and it is during this era that decisions count for most.

At the close of this chapter come two quoted conclusions :

I. "The period of special instability of the moral life is the adolescent period."

2. "This is the period in which the moral surroundings of the individual should be most carefully guarded. It is the storm-and-stress period. It is the period during which life's moral fiber is usually formed."

For these reasons, then, those who find themselves within the zone of the adolescent years are wise when they attend to everything that strengthens body, mind, and will power. ${ }^{1}$ Habits both good and bad, habits of health and of character, or the reverse, formed now will, in all likelihood, hold until death. Thus it is that the destiny of man's life does not depend upon the Fates, as the ancients thought, but upon his own choices during the adolescent years.

He may send his future prospects upward or downward according to the decisions of his unhindered will. And, more

${ }^{1}$ For facts about will power see " Control of Body and Mind," chaps. xxv and xxvii. 
serious than anything else, whether he wills it so or not, in deciding his own fate, in forming his own habits, he often decides the habits and settles the fate of his descendants for generations yet to come.

The next chapter deals with one of these habits - a habit which is able to affect the welfare of future generations, and for this reason cannot be ignored by such a book as this. 


\section{CHAPTER XIX}

\section{NICO'TINE AND ADOLESCENCE}

At a certain banquet in Chicago last year most of the men were smoking. But my friend did not smoke. Neither did the man at his right. Instead, this man said in a low voice : "The truth is, I have two growing boys, and I 've made a bargain with them not to smoke if they would n't. I knew if I smoked, they probably would, whether I wanted them to or not; that if they smoke, their sons probably will some day, and I don't want to be responsible for damaging the whole set of my descendants. That's why we 've bargained not to smoke."

As appeared afterwards, both the man and his sons knew about Dr. McKeever's smoking experiments. It also appeared that, in what he was studying out, Dr. McKeever had enlisted the help of over one hundred boys, that their ages ranged from twelve to twenty years, and that they all smoked. Indeed, it was just because they smoked that Dr. McKeever was making his tests.

He wished to see for himself what tobacco does for the boys. If it helps them either in body or in mind, he intended to pass the fact on for the benefit of other boys.

In carrying on his investigations, Dr. McKeever used the sphygmograph: This machine has a clockwork contrivance which moves a strip of smoked paper, on which a needle records the heartbeat. It is fastened to the wrist directly over the artery which passes that way, and as the 
artery throbs with the beating of the heart, the needle of the sphygmograph traces its way across the smoked paper and leaves its scientifically exact record there in black and white.

The boys were interested in the way the machine worked, and in what it told about their heart action before and after smoking.

The records were taken at different times during the year, and each was slightly different from all the others, just as the handwriting of one person always differs from that of another. On the whole, however, the various reports of the

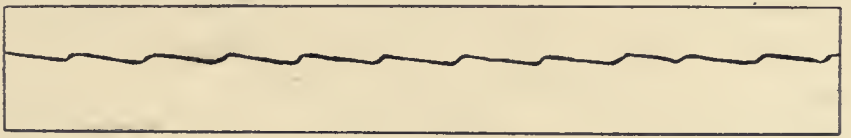

Sphygmograph Record of the Heartbeat of a Young Woman on the Verge of Nervous Prostration

The young woman does not smoke. (From Dr. McKeever)

sphygmograph explained two apparently contradictory facts, both of which are perfectly well known:

I. The smoker says he feels better, is able to think faster and to work harder, just after smoking than before the smoking began.

2. Athletic coaches say tobacco prevents success. They therefore prohibit its use by their men.

It is as if one honest man said, "Smoking does me good," while another man, equally honest, says positively, "Smoking does you harm."

To reconcile these differences, we turn to the diagrams borrowed from Dr. McKeever's record. Notice that one of these shows the heartbeat of a tired young woman. She did not smoke, but she was on the verge of nervous prostration. Compare this with the heartbeat record of the vigorous young 
fellow of nineteen who did not smoke. It shows the kind of work a healthy boy's healthy heart should do for him.

Compare both these records with the wave lines in the third diagram - the one on the next page. See that first flattened-out report (I), taken before the smoking began. It is

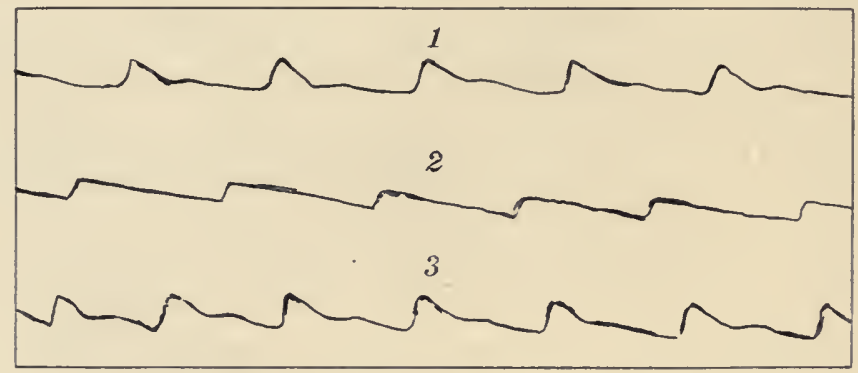

Sphygmograph Records of the Normal Heart

I, tracing for a vigorous fellow of nineteen; does not smoke. 2 , healthy heartbeat ; a calm temperament; does not smoke. 3 , heart tracing for a healthy young woman ; does not smoke. (From Dr. McKeever)

quite like the heartbeat of the worn-out young woman flabby, weak, lifeless. No wonder the fellow felt dull!

Study the next report from the same person. .See the beat bound upward when the smoking begins - stronger, faster, more vigorous. Fresh blood is being sent to every part of the body. The brain feels it first, and every thinking cell becomes more active. The smoker says he "feels good." And no wonder. Not brain cells alone, but muscles and liver, stomach and lungs and spleen, all these are getting better blood faster and in larger quantity. Even the farthest-off, smallest capillary is stretched out a little larger, and more blood than usual hurries through it for a few minutes. ${ }^{1}$

${ }^{1}$ For description of the circulation of the blood, see "The Body at Work," of the Gulick Hygiene Series, chap. ix. 
But this inspiring flush-time is soon over. Fifteen minutes have passed. Even yet the sphygmograph has not been taken from the wrist. It is still making records. And now see what has happened. All the splendid vigor has faded out. Once

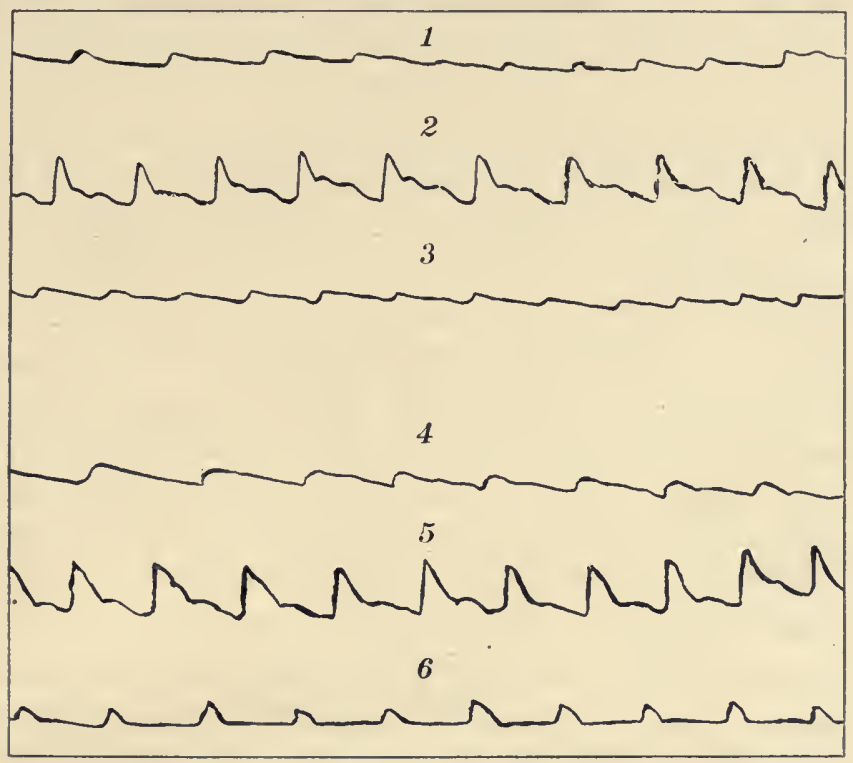

SPHygmograph Records of the Heartbeat of Two DifFERENT PERSONS

$1,2,3$, tracings made by the heart of a young man of nineteen : 1 , before smoking; 2, while smoking; 3, after smoking. He began to smoke cigarettes at fifteen. 4, 5, 6, tracings made by the heart of a young man of twenty: 4, before smoking; 5 , while smoking; 6, after smoking. Began smoking at thirteen; now uses a strong pipe.

(From Dr. McKeever)

again that heart beats almost at dead level. Brain cells lose their courage. Muscle and liver, stomach, lungs, and spleen have to do the best they can with the slow-moving blood. It brings short rations of food to cells that cry out for nourishment.. But, sad to say, the slow-pumping heart will stay in 
charge of the slow-moving blood until the next cigarette is smoked. Then it will jump into quick action again for a few minutes.

And this is why a smoker must often use fifty and sixty cigarettes a day to keep his heart up to the mark. This is why a healthy heart gets turned into a tobacco heart. This is why the steady smoker often fails where he wishes to succeed. And the fundamental reason for all this is the double character of tobacco; it is a stimulant and it is also a poison. The smoker craves the stimulation; in addition he receives the poison of nicotine.

To show the power of this poison, take the case of Dr. Kellogg's frogs. He bought a cigarette, extracted the nicotine from it, and injected part of this harmless-looking, colorless liquid into a full-grown frog. The small creature died promptly. He took another good-sized, perfectly healthy frog, injected the rest of the nicotine into it, and it too died at once.

Dr. Kellogg goes on to say that " one fourteenth of a drop of nicotine will kill a frog in ten seconds, while one sixth of a drop will kill a cat in fourteen seconds."

Homer Leslie was eight months old. He was playing out of doors, as Dr. Kellogg says, when he found a half-smoked cigarette. He put it into his mouth, chewed it awhile, was taken violently ill, and died within a few hours. The doctor said it was the nicotine of the tobacco that killed him.

If tobacco leaves could be robbed of their nicotine, smoking would be a fairly harmless habit. But the two are inseparable. When a man sets fire to his cigarette, the tobacco turns itself to smoke and ashes, and while this happens the nicotine turns into vapor. If, now, the man draws the smoke into his lungs, the vaporized nicotine goes with it. But after reaching 
the lungs, they separate. The smoke stays on all the delicate tissues of the lung cells, which is bad enough. But volatilized nicotine is not hindered by any tissues. Instead, it passes directly through the tissue of the lung cells, enters the blood stream, and is whirled to the heart by the straightest road possible.

At the moment it arrives, the sphygmograph shows what the poisoned whip has done. It has lashed the heart to vigorous action - not to last long, however, for soon the same sphygmograph shows that the vigor has gone and that the permanent condition grows worse rather than better.

The United States army gives proof of this. At an examination for the military school at West Point one quarter of the young men had to be refused admittance because they had what is called "tobacco heart" from cigarette smoking.

At another time a set of 412 boys wished to enter the naval school at Annapolis. They were examined by an officer in Peoria, Illinois, and all but 14 were turned away. As was said by the examiner, "Of the 398 rejections, the greater number were on account of weak hearts, and in the majority of cases this was caused by cigarette smoking."

So the list of those who have harmed themselves through ignorance might be lengthened.

With these facts in mind we understand why it is that, in every school and college where the subject has been looked into, people find that, on the average, smoking students rank lower and are slightly older than those who do not smoke.

In I 897, at Yale University, when Dr. Seaver made his thorough study of the matter, he found that out of every IOO students who ranked highest, 5 were smokers, 95 nonsmokers. Among the rest of the students at that time, 60 out of every 100 smoked. He also found that, on the average, 
those who did not smoke gained more in height and weight and girth of chest than those who smoked.

Remember that these Yale students were still in the growing time of life. Recall the facts of the last chapter; then imagine what it means to have a young and growing heart attacked over and over again, day in and day out, for weeks and months and years, by a poison that does its worst work with the heart itself. ${ }^{1}$.

In I9Io Dr. Meylan studied the same subject with students in Columbia University, and among his final conclusions he made the two following statements :

I. "All scientists are agreed that the use of tobacco by adolescents is injurious; parents, teachers, and physicians should strive earnestly to warn youths against its use."

2. "It has been shown conclusively by this study that the use of tobacco by college students is closely associated with idleness, lack of ambition, lack of application, and low scholarship."

Various ignorant people are ready to protest against this conclusion about the students. We must therefore let them choose for themselves between two horns of the dilemma. I give them. Either the smoker is naturally stupid and we should pity not blame him when he ranks low in his class, or he is naturally bright but by his own hand has dulled his brain with nicotine and made it impossible for that brain to do its best work in the classroom. Perhaps the latter case needs more pity than the former.

Thus far this chapter says nothing about grown men who smoke, because all agree that it is the adolescent person who suffers most. Let a man begin to smoke after he is twenty-five, and as a rule he will do himself less harm than if he began in

1 For full particulars see "Town and City," chap. xviii. 
his teens. Nevertheless, thousands upon thousands of middleaged men are bound hand and foot by the tobacco habit.

Fortunately, some of them are able to break the habit, as did Senator Depew, president of the New York Central Railroad. I give part of his story in his own words:

"I used to smoke some twenty cigars a day, and continued it till I became worn out. I did not know what was the matter with me, and physicians that I applied to did not mention tobacco. I used to go to bed at two o'clock in the morning and wake at five or six. I had no appetite and was a dyspeptic. One day I bought a cigar and was puffing it with the feeling of pleasure which is only possible to the devotee. I smoked on only a few moments, and then took it out of my mouth and looked at it. I said to it, 'My friend and bosom companion, you have always been far dearer to me than gold. To you I have been ever devoted, yet you are the cause of all my ills. The time has come when we must part.' I gazed sadly and longingly at the cigar, then threw it into the street. I had been convinced that tobacco was ruining me. I have never smoked from that day to this."

In all such care of ourselves we must not forget the bearing of the tobacco habit on the next generation. It is true that tobacco has not yet been shown to directly affect germ cells, but it is perfectly clear that it harmfully affects the smoker himself, especially if he begins to smoke before maturity. And if a man smokes, his son is almost sure to do so. In this case, therefore, the harm which passes from one generation to the next travels by what is known as social inheritance, not by that which is biological. The damage of such an inheritance is none the less real, however, for in character and habits children are apt to become what their parents have been. 
It also seems clear that the tobacco habit is a broad steppingstone to the alcohol habit. The man who never smokes rarely ever drinks, and we have seen the direct effect of alcohol on the next generation.

Since this is true, it is well to understand how the alcohol habit harms a man and when it is most apt to fasten itself upon him, threatening future generations of his descendants. We turn to this subject at once. 


\section{CHAPTER XX}

\section{ALCOHOL AS A BEVERAGE}

- Students in the medical department of Johns Hopkins University were very quiet as they listened to what the doctor said. He told them that Charlie was dangerously ill, that he was ten years old, and that his only chance for life was to have his spleen taken out. He said the boy's father was dead, that his mother had come from India with her son, and that the operation would be sure to kill him unless, while it was going on, blood could be put into his body from some one else by transfusion, as it is called.

The doctor then asked for volunteers, and four of the medical students stepped forward at once.

A sample of blood was drawn from each person. This was tested, and the choice fell on a healthy young fellow of twenty-four.

Next day came the operation. The surgeon opened an artery in the student's arm, and a vein in the arm of the small boy. He then put the two openings opposite each other and joined them together. After that, whenever the heart of the young man beat, it sent a strong current of rich blood into the feeble body of the small boy. From being very pale, the lad gradually grew pink. Even his finger tips changed color slightly.

The transfer of blood went on for about two hours; and during this time Charlie received between one and two quarts of blood. 
Before the operation began, the doctor said there was but one chance in a thousand that the boy would live. After it was. over, he said it was those quarts of splendid blood that saved the lad - that the new blood had given feeble cells a new environment and made it possible for them to do what was necessary to keep the body alive.

Now suppose both Charlie and the student had been drinkers. ${ }^{1}$ What about the outlook then? Sir Frederick Treves says: "Having spent the greater part of my life in operating, I can assure you that there are some patients that I don't mind operating on and some that I do ; but the person of all others that I dread to see entering the operating theater is the drinker. $\mathrm{He}$ is a most dangerous feature in connection with the surgical life."

The fact is that alcohol gets into the blood more easily than does any food, that it is carried by the blood directly to all the cells of the body, and that it seriously poisons every cell it reaches. It does this whether the cell is part of brain, nerve, or muscle.

Now cells reached by alcohol-bearing blood suffer in two ways: (I) they are slower in getting nourishment from the blood; (2) they are slower in getting rid of their waste. This is why the surgeon dreads an alcoholic person. As a rule, his wounds are slower in healing and his heart is not so reliable during the operation.

Every cell is affected, but no cells suffer more promptly than those in the brain.

Last summer, on a steamboat between Seattle and Vancouver, I myself saw what happens when alcohol is in the environment of brain cells.

1 The student had never used either alcohol or tobacco; neither had his ancestors for three generations. 
The fellow was young. He talked loud and fast, with a thick voice. He said he knew he was getting drunk and that he did n't care. He still had the power of choice, and he called for more drink. He asked everybody to drink with him; he said he had plenty of money and that when he reached Vancouver he could get more.

Those of us who saw him and heard him knew that, even while he talked, tainted blood was washing its way over his most sensitive brain cells. We knew that already those cells which gave best aid to his wit - those which controlled his judgment - were dulled.

Later the fellow went off with his friends. Later still he was staggering across the deck. His friends were with him, one on each side to keep him steady. They looked shamefaced as they held him up. To the rest of us the sight of it all was exceedingly sad - not because the fellow could n't talk straight, not because he staggered, but because of what we knew had happened to his brain cells. ${ }^{1}$ We knew that by the power of his own hand, by the choice of his own brain, he had thrown uncounted millions of these brain cells out of service.

Study the diagram (p. 148). It shows the order in which brain cells always develop in the human embryo. First come cells that control the heart, and last of all those that control judgment and will power - the inhibitory centers of the brain, we call them. By this chart of his Dr. Chapple shows that alcohol damages brain cells in the reverse order of their development - that cells which control judgment and will power are cut out first, those that control the heart last.

Now we understand what the alcohol habit means, and why certain anti-alcohol people were troubled when they found a peculiar little bottle in the hands of school boys in Ohio.

I See "Control of Body and Mind," chap. xxvi. 

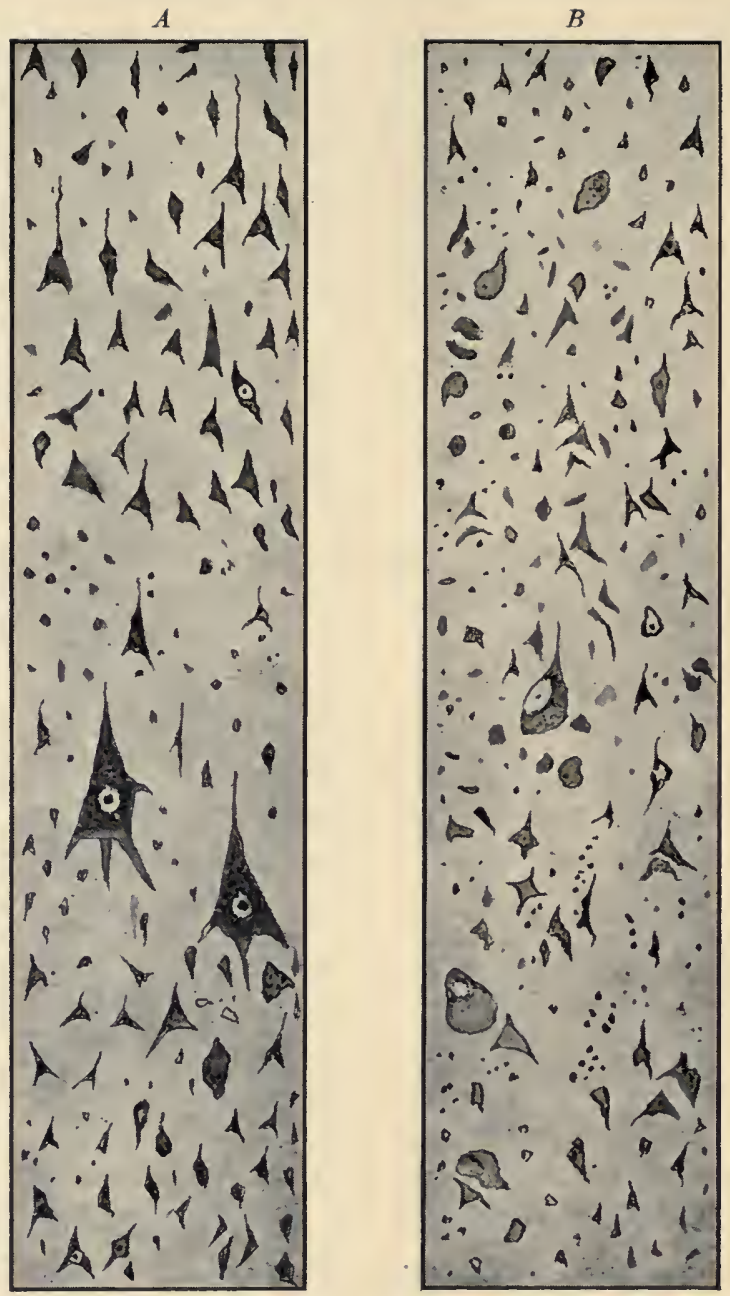

Cells from the Cortex, with Fibers not Given

$A$, cells from a healthy brain; $B$, cells from the brain of a victim of alcohol. Notice the changed shapes, smaller size, and diminished number of the cells in $B$. Their altered condition explains the inefficiency of an alcoholic brain. (After Horsley) 
The bottle itself is three inches high and an inch and a quarter across. It has a cork stopper, and the stopper has a bone top to it. A glass tube goes through the stopper, down into the contents of the bottle. A rubber tube stretches up from the top of the stopper. On the end of the tube is a bone mouthpiece through which the liquid in the bottle may be sucked up.

The whole combination was packed in a small box which it fitted exactly, and on the box was a card which gave the name and address of the saloon from which it came.

This bottle had passed from hand to hand and from mouth to mouth until the teacher found it. At that time it was half full of whisky. And what was the object of the bottle and its whisky? The following bit of history answers the question.

Several years ago the State Liquor Dealers of Ohio were gathered in Wirthwein Hall, Columbus, and one of the speakers had for his subject "How to Build up the Saloon Business." Among other things he said :

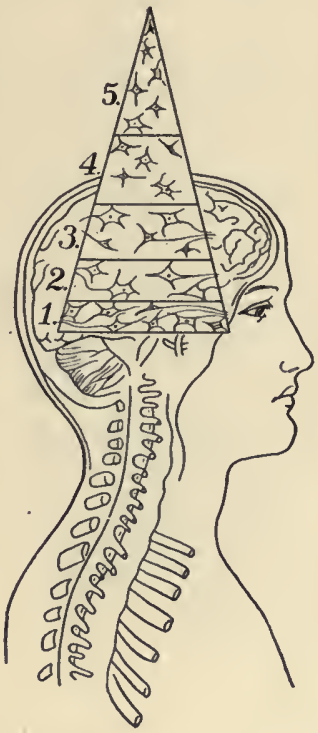

Diagrammatic Scheme OF THE ORDER OF DEVELOPMENT OF BRAIN

Centers

1 , heart centers ; 2 , lung centers; 3 , locomotion centers ; 4 , knowledge centers; 5 , inhibitory centers. (From W. A. Chapple) "The success of our business is dependent largely upon the creation of appetite for drink. Men who drink liquor, like others, will die, and if there is no appetite created, our counters will be empty, as will be our coffers. Our children will go hungry, or we must change our business 
to that of some other more remunerative. The open field for the creation of appetite is among the boys. After men are grown and their habits formed, they rarely ever change in this regard. It will be needful, therefore, that missionary work

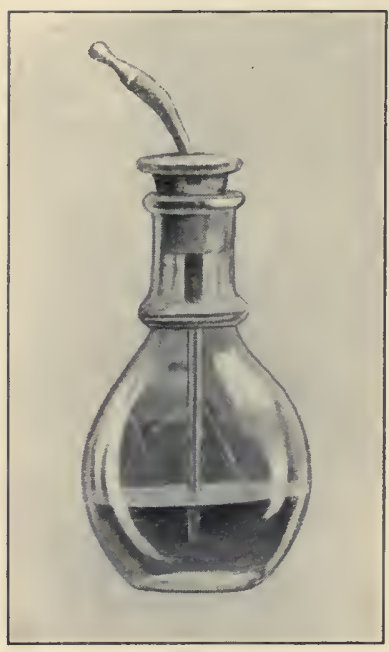

A BotTle of Whisky CirCulated to "Create A ppetite" AMONG THE BOYS

(From the Anti-Saloon League) be done among the boys, and I make the suggestion, gentlemen, that nickels expended in treats to the boys now will return in dollars to your tills after the appetite has been formed."

It was as if the man had said: "My friends, unless we can help ruin the boys by creating in them an appetite for alcohol, we ourselves must go out of business. We must destroy them for the sake of our individual pocket-books."

The man supposed he was talking to liquor dealers alone. He did not know that an antialcohol man was in the meeting, and that he was taking down shorthand notes of everything said.

From his own point of view the speaking delegate was quite right. Unless boys can be secured, - unless they will consent to damage their own brains, - the liquor business of the world is doomed. Dr. Alexander Lambert shows this in a table of figures which he made out. The inspiring motive of his search was the number of people ruined by alcohol whom he met in Bellevue Hospital, New York City. There were so many of them that he decided to find out how old they were 
when they began to drink. He received full answers from 258 persons. The table itself tells the rest of the story.

Age when 258 Persons began the Alcohol Habit

Before the age of 6 . . . . 4 persons

Between the ages of 6 and 12 . I 3 persons

Between the ages of 12 and 16 . . 60 persons

Between the ages of 16 and 21 . . 102 persons

Between the ages of 21 and 30 . . 7 I persons

After the age of 30 . . . . 8 persons

By this table we see that 69 per cent of those who had the alcohol habit, began to acquire it before they were twenty-one years old, and that only 8 persons out of 258 began to use alcohol after they were thirty; that is, after they were fully mature.

It is evident, then, that if a boy can keep free from the habit during the wonderful years between fourteen and twenty, he has a good chance of escaping altogether.

Those who sell alcohol are bright enough to know this. They know that if they wish to continue their own particular kind of business, they must make sure of the boys. Their motto, therefore, seems to be "Gather in the boys and ruin them." But certain boys are long-headed enough to decide not to be gathered in. They say the environment of their own brain cells and the welfare of their own descendants mean too much to them to be sacrificed in this way.

Not individuals alone, but nations also, are coming to the same conclusion. In I9I4 Secretary Daniels of the United States Navy issued the following order:

"The use or introduction for drinking purposes of alcoholic liquors on board any naval vessel, or within any navy yard or station, is strictly prohibited, and commanding officers will be held directly responsible for the enforcement of this order." 
The power which man has to recognize danger, to control his habits, to decide his own destiny, and to guide the future of the race, turns our thoughts to early evolution times again, and shows how it has come to pass that man is now able to choose either safety or damage for body and brain alike, and how he succeeds in either strengthening or weakening his own character through the highest power that evolution has given him - his brain. The next chapter dwells on this point. 


\section{CHAPTER XXI}

\section{THE CROWN OF EVOLUTION}

When monsters lived and ruled the earth, it was bulk of bone and muscle, not size of brain ${ }^{1}$ or keenness of wit, that counted.

The creatures had eyes and ears and all five senses, but not one among the number carried a brain so efficient as the smallest normal man-brain that guides the life of the smallest man to-day.

Think, then, of the change that has come about. To-day it is brain, not bone or muscle, that rules the world. The elephant and the rhinoceros still live, but it is small man with his active brain that masters them when he meets them.

To understand how this has come to pass, recall the fivelinked chain of evolution, discussed in Chapter IX. Go back far enough in history and apply the chain to the evolution of brain in vertebrate animals. Recall the fact that in every family of every generation there has been endless variation. Also ask this question: Other things being equal, which animals have the better chance to survive, those with quick wit or those with slow wit; those with an efficient or those with an inefficient brain?

The question answers itself. As a rule, quicker wit means better chance to find food and to keep it, to scent danger and to escape it, to succeed in competition and to survive in the struggle for existence.

${ }^{1}$ For description of the human brain and the work it does see "Control of Body and Mind." 


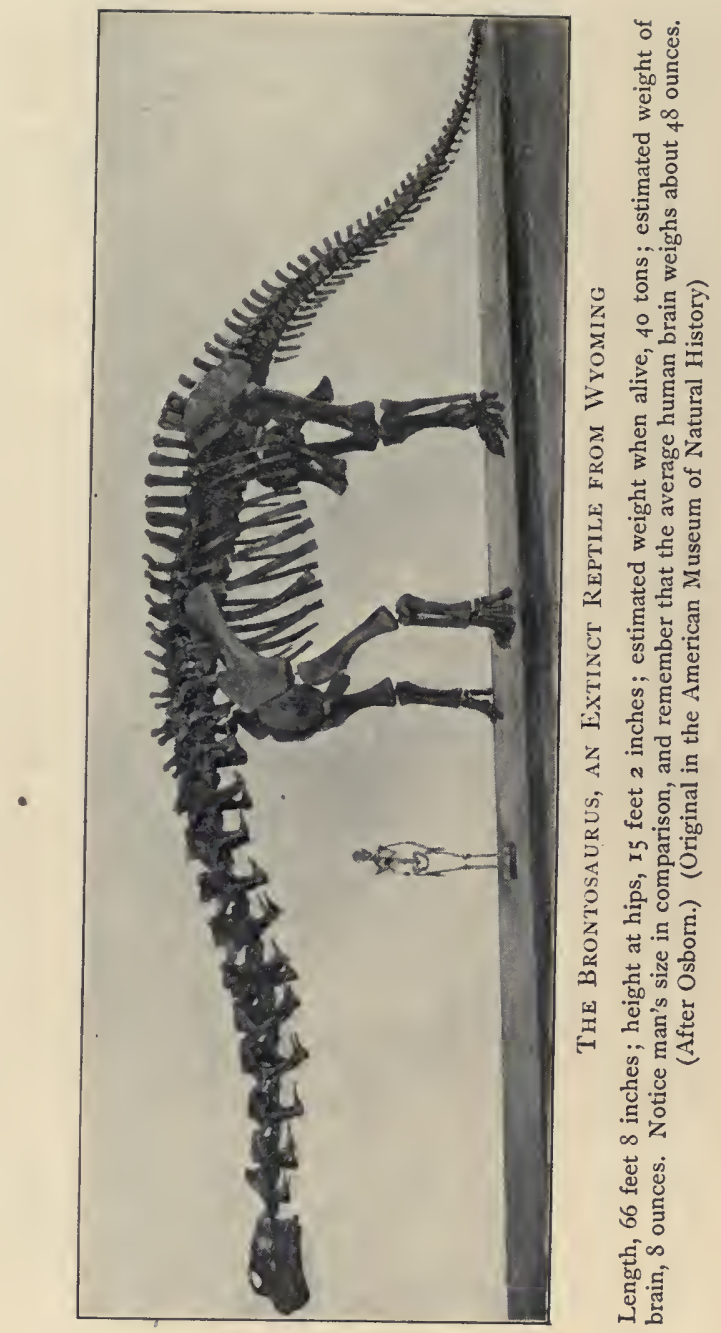




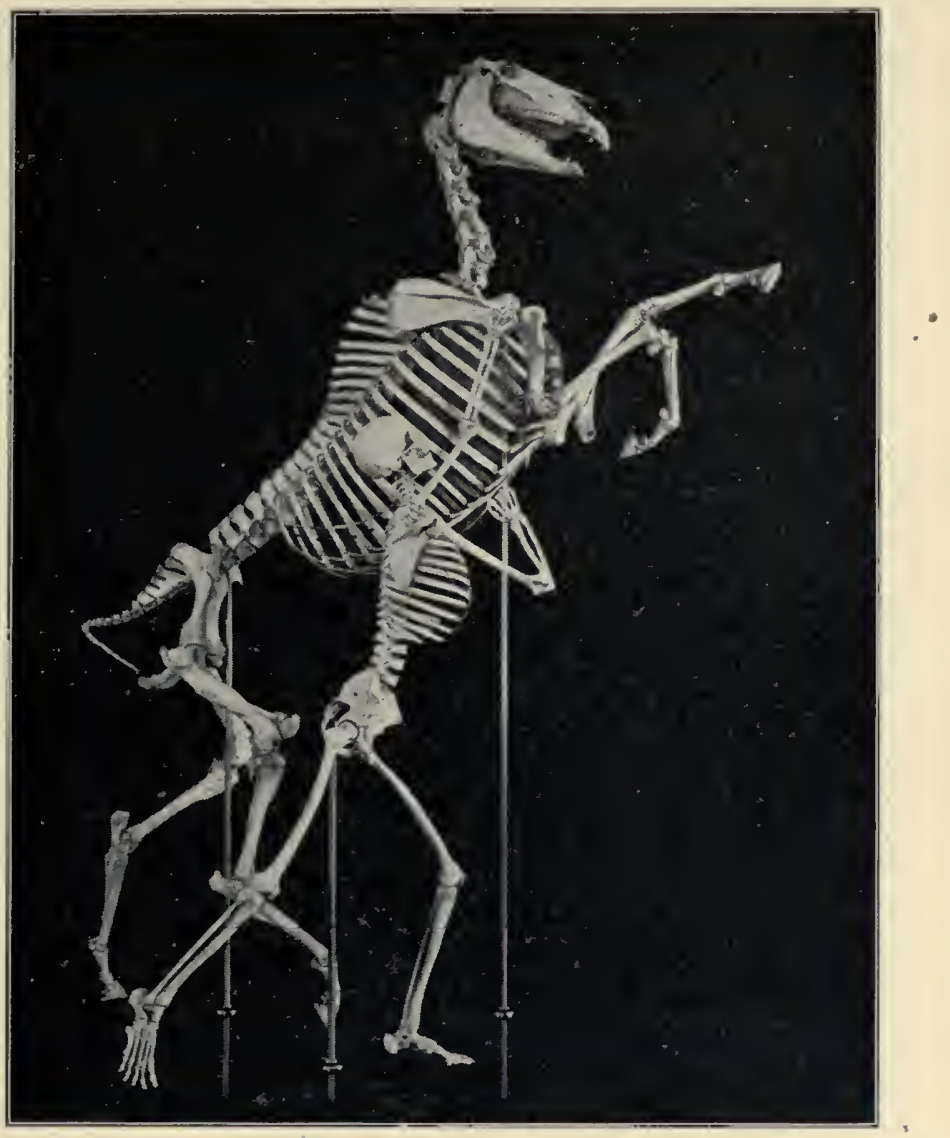

Skeleton of Horse and Man placed for Comparison

Take special note of the contrast in brain capacity of the two. Also trace resemblances in general structure : leg bones, ribs, and vertebræ that correspond; brains, faces, and feet that are different developments from a common plan. (From the American Museum of Natural History) 
More than this, in the case of man, while brain developed, hand and fingers developed too, until at last the human animal, man, found himself the owner of a brain able to plan great things, and of hands able to carry out great plans.

Thus man stood at the beginning of his new era, and it was at this point that a different kind of inheritance stepped in and helped take charge of human affairs; for after the brain was well developed, each generation began to make improvements of its own, and to inherit other improvements which previous generations had made.

To understand the situation, forget the present for a moment ; sweep away all thought of our modern civilization, all memory of our towns and of our cities, of our homes, our schools, our shops, our libraries, our banks, and our churches ; forget our waving fields of corn and grain, our orchards, our mines, our railroads, our steamers crossing the ocean, our wireless stations and our aëroplanes.

Then go back in thought to our earliest ancestors. They were men and women with bodies, brains, and hands like ours, but nowhere in those prehistoric times do we find a sign of the comforts and the inventions which surround us to-day.

Without fire, living in caves, with leaves and skins for covering, eating raw food as they could get it, our remote ancestors lived and died in the midst of discomforts which would appal us, their descendants.

Even language was but getting its start. One by one, however, new sounds and new words were invented for this thing and that, until, in course of time, men and women were talking. They could now counsel with each other. This was a priceless advantage which could be passed on from one generation to the next. It was a giant stride upward; not a longer one, however, than was taken by the first fire-maker. 
He had seen lightning in the skies, perhaps had even watched molten lava as it boiled and bubbled, perhaps had struck sparks from flint stones as he knocked them together; but never yet on the earth had there been a blazing fire lighted by human hands, guided by the human brain.

At last, however, the discovery came. Some person somewhere may have used his brains and his hands, may have rubbed two sticks together hard and fast, as some primitive peoples now do, and may thus have started the first fire ever kindled by man.

No one knows the date of that first lighting nor the precise method employed.. All we know is that such firemaking was as truly

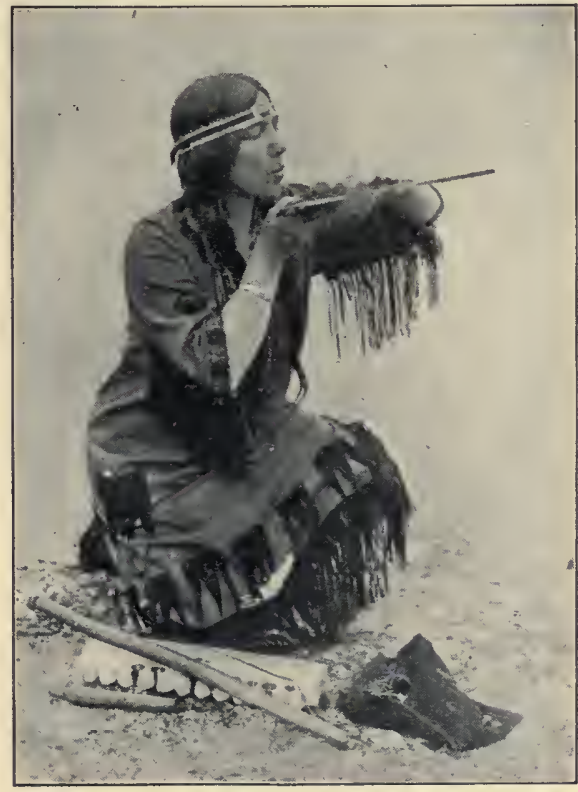

Courtesy of Mrs. L. H. Gulick

Making Fire in the Primitive Way

This Guardian of the Camp Fire Girls has secured a spark from rubbing sticks together. She is now - blowing that spark into a flame the result of mental action as was the invention of the steam engine by James Watt in 1736 . He who made the fire discovery has blessed all generations from that day to this, for each generation has inherited the advantage of the discovery, and has passed the advantage on to the next generation. 
So, too, when man found he could gather grains from certain grasses, plant them together in the same field, and raise wheat and corn for human use. This was another milestone in the journey toward civilization - another blessing to be handed on to later generations.

One after the other also came the inventions.

Man left his cave and built himself a hut - the beginnings of architecture. He made bow and arrow, tools and traps, rafts and canoes. And each separate invention was the result of brain activity. Memory, curiosity, imagination, reason, will power, choice - all these he pressed into service.

Moreover, by using fingers and toes as numbers he began to count, and all our present-day higher mathematics come from that early start. The decimal system itself is but a reminder of the ten toes and the ten fingers of those early ancestors.

In some such way, through the ages, discovery and invention followed each other up the road toward our modern civilization. Each generation inherited what had gone before; each made new inventions, new discoveries; each in turn passed on to the next generation what it had received and cared to keep.

We of to-day have our occupations and our recreations, our comforts of life, our requirements and our luxuries, as a rolled-up inheritance from past generations of men, and no form of inheritance is more valuable to us.

We see, then, that in addition to the physical inheritance which each of us has received, there is this other form of influence, this accumulated knowledge, these gathered-up experiences, which reach us as a social inheritance from our ancestors, and which we, just as necessarily, pass on to the next generation. 
In both lines of inheritance the present generation picks up the threads of life where the last generation stopped its spinning. The next generation will begin where the present generation leaves off ; and from these threads the warp and woof of human history is being woven.

Nor is this all. Side by side with inventions and discoveries walked the spiritual part of man. It lifted him above the sordid life about him. It set him on a pinnacle high above all other creatures. It made him conscious of time and space, of past and future. It gave him knowledge of right and wrong, a feeling of responsibility for other men.

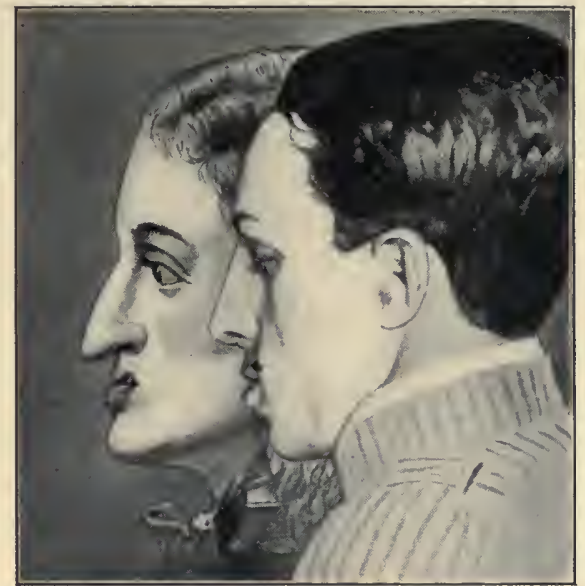

The Hapsburg Jaw, a Famous Example of Physical Inheritance

Charles the Second of Spain inherited it from an Austrian princess in 1661 . The present king of Spain has it from the same source. In this illustration the young king's face is so turned that the distinction is not emphasized. (After Stoddard Goodhue, in the Cosmopolitan Magazine for July, 1913)

Before man arrived, no creature had ever studied the past for the sake of understanding the future. Man does this. He learns the laws of development by studying the past, and he applies these laws in shaping the future. Because of this he now walks the earth with conscious power. $\mathrm{He}$ knows that by using knowledge, judgment, and will power he may alter his own destiny almost at will. He also knows that by his personal decisions in this generation he may 
decide the fate of future generations. He has hopes, ambitions, longings, and he loves his fellow men. When the need comes, he even dies to save them. He throws his thought into future years and believes in life beyond the grave.

Besides all else he has studied the laws of modern life so well - has learned so much about health and the way to secure it, about happiness and the way to attain it - that he is now able to lengthen human life or to shorten it, to bless the human race or to curse it, by what he knows and by what he does in carrying out the commands of his unhindered will.

There has been both advantage and disadvantage in this turn of evolution which gave man his crown - his brain.

The advantage is that there is hardly any limit to what man may now do for himself and for his descendants, provided he has a normal, healthy, well-trained brain, and provided it decides to serve him according to its own best judgment.

The disadvantage is that even when his brain is not normal and healthy, even when it has been badly trained and is ignorant, even when its desires are for such things as will harm itself hopelessly, it can still make choices; it can still choose a road to its own destruction and force the consequences on the children of the next generation.

We therefore meet this strange fact of evolution, that through his highest gift, the brain, man is now able to do himself and his descendants more harm than can be done to themselves by any other creatures, however large or small their brains may be.

In point of fact, from the beginnings of brain power until now, man has made decisions both wise and unwise; he has been guided by choices both good and bad. 
As a rule, however, best choices have prevailed. These have drawn men ever closer together. From being scattered savages, fighting each other for life, human beings have gradually gathered in larger and more friendly groups, until to-day we have cities where thousands, even millions, of people live together and depend upon each other. ${ }^{1}$

Moreover, as groups grew larger during the ages the notion of family life also grew; and now, in all civilized countries, the family is recognized as the fundamental unit of society. To form it we have a man, his wife, and their children.

1 For description of the way in which country towns are turned into crowded cities, see the first three chapters of "Town and City." 


\section{CHAPTER XXII}

\section{FAMILY RESPONSIBILITY}

Thus far the pages of this book have made it plain that throughout life there runs the great fact of sex, and that, because of sex, life on the earth is able to go on from one generation to another.

In human evolution, however, man has crowned all individual relations with the family relation. He has made this smallest group of human beings - parents and their children, with their home life - the center of his civilization. Without the family we should have no government, no commerce, no art of any sort.

More than this, the environment supplied by each family in each home shapes and changes, for better or for worse, all who live in that home.

And because the family is so important to the human race, because it concerns each one of us so vitally, also because, to a large extent, we individually determine what kind of homes we shall have, therefore such a book as this must take the laws of family health into serious account.

Let us not forget that any disease which travels from person to person moves surest and swiftest among the members of the family circle.

When scarlet fever or smallpox, tuberculosis, typhoid fever, whooping cough, diphtheria, or measles breaks out in any home, the members of the family itself are in more danger than other people, because they live closest together. 
And what are towns and cities but groups of families crowded together, ever influencing each other for better or for worse? No wonder, then, that in every land the future

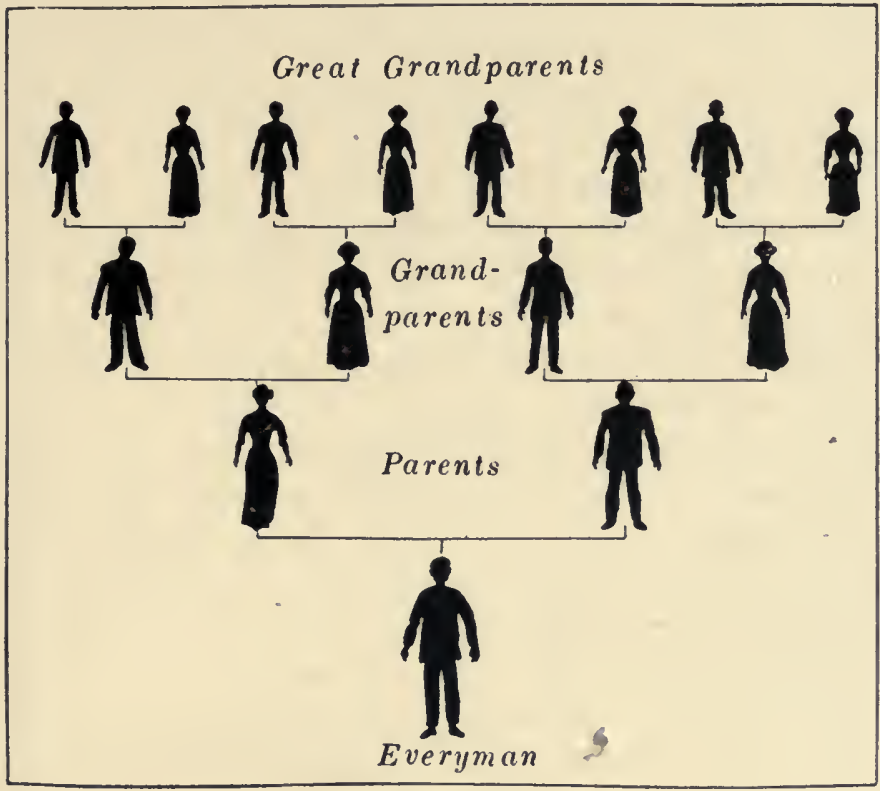

OUR ANCESTORS

Notice how the ancestors of each one of us (that is, Everyman) double with each generation that reaches back through parents, grandparents, great-grandparents, etc. It is from this unnumbered host of ancestors that we receive both our physical and our social inheritance. An old Shinto maxim of Japan is "Let men know by your deeds who your ancestors were"

of the nation depends on the health of the bodies and the health of the minds of its families.

This is so true that, for nations and cities as well as for the families themselves, the motto of modern life is, "Protect yourselves and the next generation by obeying the laws of family health." 
Man has indeed learned at last that, for the sake of this generation and the next, he must know not simply the laws of individual health and of inheritance, but also the laws of family health.

We shall soon see that these three sets of laws travel hand in hand, and that ignorance about any one of them is dangerous to all concerned.

In former times the watchword of a nation was: " $\mathrm{Be}$ a patriot. Be ready to die for your country."

In modern times the command is : "Be a patriot. Live right, and live for your descendants." Put in other words, this means: Don't die needlessly. Keep yourself vigorous and healthy, and so conduct your life that you will be a worthy ancestor of coming generations.

This modern patriotism is indeed the nobler kind, for if it is held to and carried out by successive generations of men, far-away descendants of those who live to-day are sure to be a blessing to their country, whether they live for it or die for it.

Through a knowledge of cause and effect and through the choice of his own mind and the power of his own will, a man may prove that he is worthy of the crown which evolution has placed upon him.

No test of manhood or of womanhood is greater than that which has to do with the welfare of family life.

The following chapters give facts about health, and about its relation to inheritance, concerning which no thoughtful person can afford to be ignorant. 


\section{CHAPTER XXIII}

\section{PRO'TECT THE STREAM OF LIFE}

In the Journal of the American Medical Association for September 2, I9I I, Dr. Schamberg describes what he calls "An Epidemic of Chancres of the Lip from Kissing."

It appears that on the fourth of March, I9I I, a group of young men and women ranging in ages from sixteen to twentytwo gave a minstrel performance, had a banquet afterwards, and closed the evening with what were called kissing games.

No one suspected any danger, for all were light-hearted and thoughtless. A certain young man was especially attractive and evidently quite popular. His one blemish, so far as appearances were concerned, seems to have been a sore on the lip, which led one girl to say that she let him kiss her "with reluctance and wiped her own lips afterwards with a handkerchief." As it happened, however, it was a plague spot of the worst kind. Any man or woman who knows about different kinds of contagious disease would choose smallpox or scarlet fever or both together rather than the disease represented by the small sore which showed itself on the lip of the young man.

Any intelligent doctor would have told the fellow that the sore itself was swarming with contagious microbes, that it was not safe for him to mingle with healthy people, and that it was a wrong of great cruelty for him to press that sore, with its millions of microbes, against the lips of any other human being. 
The evening came to an end, but the laws of cause and effect did not go out of service. On the twenty-fifth of March one of the girls he had kissed found a sore on the right side of the lower lip, and it became as large as a pea. A second girl discovered her sore early in April. In fact, in her case there were two sores, one on the upper, the other on the lower lip - a double proof that microbes had entered her body and were doing damage there. On the thirteenth of April a sixteen-year-old girl noticed that she too had the dreaded sore. Six cases followed each other through the months of March and April, and each victim was one of the number that had been kissed by the young man at the entertainment.

Dr. Schamberg goes on to say that " this most unfortunate epidemic should teach a lesson which cannot be too strongly impressed on the public, that is, the danger of promiscuous kissing."

Perhaps some one may answer: "But a little sore is n't anything. I 'm not afraid of sores." No, an ordinary sore is nothing, but this particular kind of sore is a signed declaration that the body has been invaded by a foe more cruel than death itself, that the foe has already increased its forces beyond the power of human reckoning, that these forces have entered the blood stream, that the entire body in all its parts is threatened, and that even the children of the next generation are in danger.

Whether the disease is passed on by kissing or by some other contact of the body, the microbes always pass from one person to another under stated conditions :

1. The disease must reveal itself in a sore.

2. This sore must come in contact, either directly or indirectly, with a surface of the skin through which there is an 
opening. A crack, a scratch, a wound of one kind or another, is all that is needed. Into this opening the microbes make their way. They may go either from the sore itself or from something that has touched the sore and become contaminated by the microbes. Once in, these microbes travel about in the blood stream and establish themselves in fresh tissues, where they multiply fast.

3. A cracked, moist mucous membrane is an ideal place of entrance for the microbes. Lips, therefore, are often very vulnerable, for they are easily chapped and parched and cracked.

When a cracked mucous membrane comes in contact with one of the sores, it is like the offer of a new home to overcrowded microbe residents. They accept the offer at once and establish themselves in the new place with extraordinary rapidity. Twelve hours after the first contact is made, even a surgical operation will not avail to cut them out. They are intrenched beyond recall. And yet - and here is the most alarming factor in the case - no symptom of the disease, no sign of sore, will show itself until several weeks after the first contact was made.

Notice the date of the banquet, March fourth; notice the dates scattered along afterwards when sores made their appearance. It is true that if the trouble is discovered at once, if it is reported to the doctor without delay, and if special treatment is persisted in for three or four years afterwards, a person may hope to be entirely cured. It is also possible that a remedy which has recently been discovered may cure more rapidly. Nevertheless, the appalling fact remains that the disease itself is one of the most terrible of the contagious maladies which man is fighting, and unfortunately it is seldom reported when it first appears. 
It is well to know that the first sore always shows itself on the identical spot where the cracked membrane and the diseased surface met. No wonder it is called "the mark of the devil," for it shows just where the microbes entered.

Once established, they multiply, and as they multiply they manufacture a poison. This poison is poured into the blood stream, and wherever the blood goes after that, there also goes the poison of the plague.

"At the end of a few weeks," writes Dr. Forel, "eruptions appear on the body and face, and then commences a series of disasters the cause of which may be suspended over the victim for his whole life like the sword of Damocles, even when he believes himself cured, for the cure is often uncertain. This disease may remain latent for months and years, to reappear later in different organs. It causes ulcers of the skin and mucous membranes; it sometimes causes decay of the bones; it affects the walls of the blood vessels, causing them to become hard and brittle; it causes diseases of the eye (especially of the iris and retina), tumors in the brain, paralysis, etc. In fact, it spares none of the organs of the body.'

Speaking of this disease, which is called syphilis, Dr. Morrow says: "It plays the rôle of sapper and miner among diseases; it undermines the constitution, weakens the organic defenses, diminishes the capacity of resistance, and thus renders the system an easy prey to other forces of disease."

Dr. Osler speaks of it as "the worm that dieth not and the fire that is not quenched." Miss Lavinia Dock, who has cared for patients in all their degrees of suffering, says that "mucous patches may appear in all or in any part of the mouth and gums, tongue, tonsils, and pharynx. They may also appear at the corners of the lips or in the nasal lining." 
Now it is because of these patches in the mouth, on the tongue, and on the lips - each one a center of infection that people everywhere are not only anxious to avoid personal contact with those who are thus diseased, but are also getting rid of the public drinking cup which diseased persons may have used, and in its place we now have the sanitary drinking fountain. Here nothing but water touches the lips. Whether a person has scarlet fever, tuberculosis, smallpox, whooping cough, measles, or mucous patches on his lips, no one can by any chance pass on his disease by means of a sanitary fountain. But with the public drinking cup, how

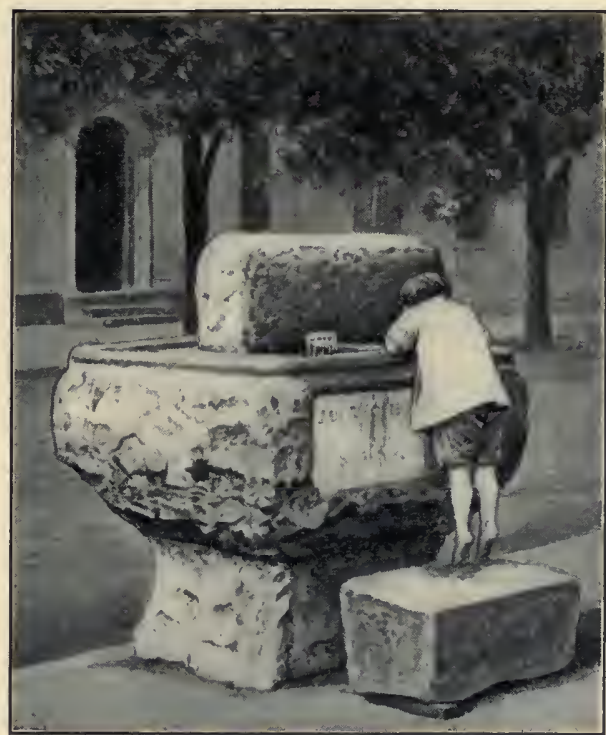

Modern Sanitary Bubble Fountain different! When you have the opportunity some day, watch one of these in a crowded city. I myself have done this.

First came a healthy, vigorous-looking carpenter. He emptied the cup, seemed to enjoy it, wiped his mouth, and went away. "Quite a healthy man," I said to myself as he passed on. "Probably no danger from him."

Next followed two giggling girls. Each took a sip and hurried off, still giggling. "Silly," I thought, "but not diseased." 
A newsboy seized the cup as they dropped it, and was gone with a rush to sell his papers. "Fine boy," was my comment.

Then came a sight that frightened me - a man with every mark of disease upon him. His walk betrayed him; his eyes betrayed him ; and, worst of all, he had visible sores on his

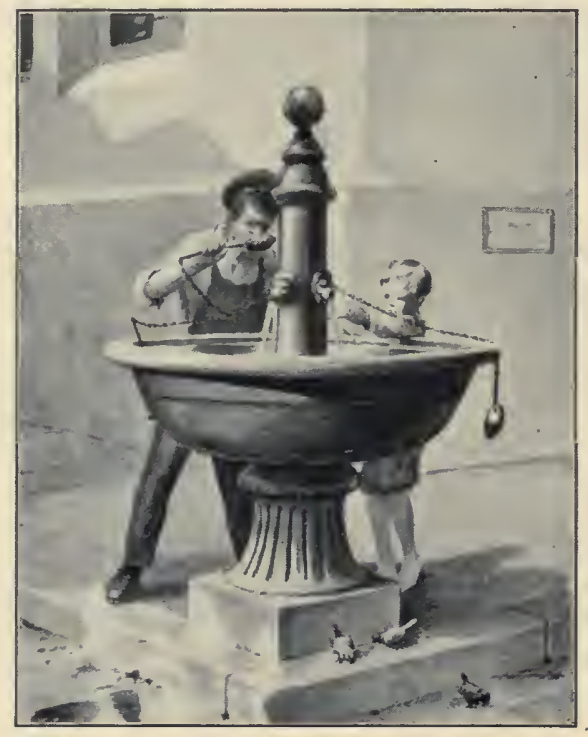

Old-Fashioned Drinking Fountain

lips. He too drank from that cup, and my frightened query was, "Whatmicrobes have you left there, unfortunate man?"

Next stepped up a woman and a little girl. The child may have been five years old, and she was evidently thirsty. I saw that her lips were slightly parched and cracked. My heart stood still with fear. Were the cracked lips of the sweet child to touch the cup the man had used? I could not reach her in time to warn her. Then came relief. I saw what the woman did. She rinsed the cup carefully, filled it to overflowing, held it to the child's mouth, and told her to suck the water up from the middle of the cup, not to touch her lips to its edge.

This worked well. Some of the water was spilled, but they both laughed and went their way. I saw that the lips of the child had touched nothing but water. She was safe. 
If all were as wise as this woman, even public drinking cups might be used; but many are ignorant, and as I watched the cup I knew that day after day there was danger for the city through that single cup alone. For over and over again, whether a man betrayed his condition or not, there were sure to be many who used the cup and left dangerous microbes on it.

Fortunately for the race, the particular microbes discussed in this chapter do not live long when they are on surfaces outside the body:

It is well to bear in mind and to act upon the following rules :

\section{Rules of Protection}

I. Never use knife, fork, spoon, cup, or any other article after another person until it has been washed.

2. Never put into the mouth pins, pencils, money, whistles, chewing gum, or any other article that may have been in the mouth of another person.

3. Never let the diseased surface of any diseased person touch the delicate membranes of any part of your body. Older people sometimes kiss children on the lips. This should never be done. Let old and young alike kiss each other on the cheek, not on the lips, for the thick, unbroken skin of the cheek is a protection against the invasion of microbes.

Since these laws of prevention are easy to follow, we wonder why cities and citizens have been careless so long. The answer is that most of us are both ignorant and thoughtless. Few realize that, of all the diseases that come to man, this is the only one which is able to travel the road of direct inheritance from one generation to the next - the only microbe disease which seems to affect germ cells themselves, and which stays with the cells as they multiply and become a baby. 
When this occurs, as Dr. Morrow says, "instead of the rosy, healthy, well-formed child, there may survive a puny, frail being, feeble in mind and body, an object of disgust and horror, doomed, if not to early death, to bear through life the stigmata of degeneration and disease."

The baby does not always look ill at birth, however. Indeed, the signs of its inherited disease may not come until weeks or months or years afterwards.

Many pages of many books are crowded with cases in which this curse has appeared in the next generation, but they are too sad to be recounted here. He who is armed against the danger is able to save himself and his descendants. His fate no less than their fate rests with himself.

The disease studied in this chapter arose long ago in connection with the immoral lives of men and women, and it is now largely so transmitted. Indeed, very few of those who live the immoral life are free from one or the other of the two diseases mentioned in this and in the next chapter. Nevertheless, the fact of contamination does not necessarily prove immorality, although the resulting suffering is not lessened. The only way to safety is along the lines of protection already stated. 


\section{CHAPTER XXIV}

PREVENTION OF BLINDNESS

The doctor knew that certain microbes had entered his right eye, that they were multiplying there with astonishing rapidity, and that but one thing in the world could save his sight. He was on the night boat going from Boston to New York and had none of the needed medicine with him. Neither was there any of it on board, and the boat was too far from port to put back to Boston for it.

The results were inevitable. When they reached New York the next day all hope of saving the eye was gone. The other eye had to do double duty for the man ever afterwards.

The doctor knew perfectly well that this was a definite effect from a definite cause. He could point to the place and to the hour of the day when he had cared for a newborn baby. He knew he had used medicine on the baby's eyes, because they were threatened by microbes that bring blindness. But he did not know how other microbes of the same kind, in the same room, could have entered his own eyes.

Usually it is the babies and ignorant people who suffer, not the doctors.

Dr. Howard reports the case of a woman whose eyesight he tried to save. She worked in a hotel, was vigorous and healthy, with perfect eyesight, and she had a daughter five years old. In this hotel the woman handled towels, linen, sheets, and all such things as are used by others - soiled articles on which disease microbes are often left. 
"One day," writes Dr. Howard, "I was called to see her, stretched on a bed, with pus-swollen eyes, crying from lacerating pains, feverish, and frightened. There was no possible help for her; it was too late; her eyes had already been destroyed. Two days before I had been called in to see her, she had felt a little inflammation and, not having the slightest idea what the trouble was, kept wiping the pus away with a handkerchief. Of course the child slept with its mother. It is a simple matter of unknown detail just how the pus was transferred to the child's eyes, but it was, because on this day the pus was penetrating the tissues, and the lenses could not be saved. Mother and child blind for life! And this mother," as Dr. Howard exclaims, "had been sent out into the world with a high-school diploma! Educated! Oh, it is pitiable, pitiable; it makes the physician's blood boil to write or think of these thousands of cases that could have been saved had our parents, teachers, ministers, done their duty."

The woman herself did not know that from sheets, towels, etc. disease microbes might reach her hands, and that those hands should have been washed before they so much as touched her eyes.

Every blind asylum in every state and city bears testimony to the power of this microbe. In I 890 there were over 50,000 persons in the United States who were totally blind, with about as many more who were partially blind, and it is estimated that over one quarter of the number were made blind because these gonococcus microbes entered their eyes at birth and so scarred the conjunctiva and the cornea that light could not pass through to the retina. In every such case the result is blindness.

Dr. Neisser says that in Germany 30,000 people are blind through this disease alone. It is also shown that fully 


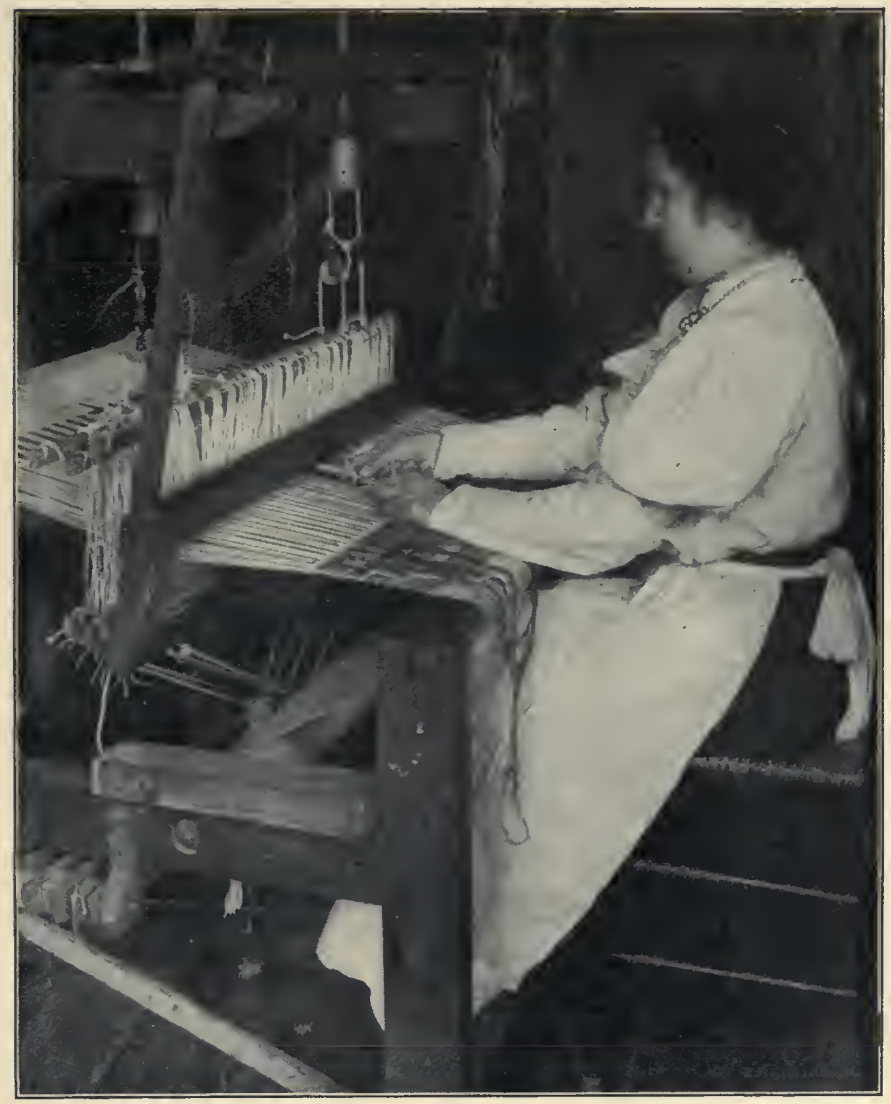

\section{BLIND WeAver}

Art Fabric Shop, Massachusetts Commission for the Blind

one quarter of those who are blind, in Europe as well as in America, owe their blindness to the same cause, and that, had they received treatment when they were born, their sight would have been saved. 
"Blind from birth," we say; yet in point of fact they were not blind when they were born. They came into the world with eyes as sound as yours or mine. Blindness came shortly afterwards. It came because, at birth, the microbes were present as a disease on the tissues of the mother. From the mother they found their way into the eyes of the child.

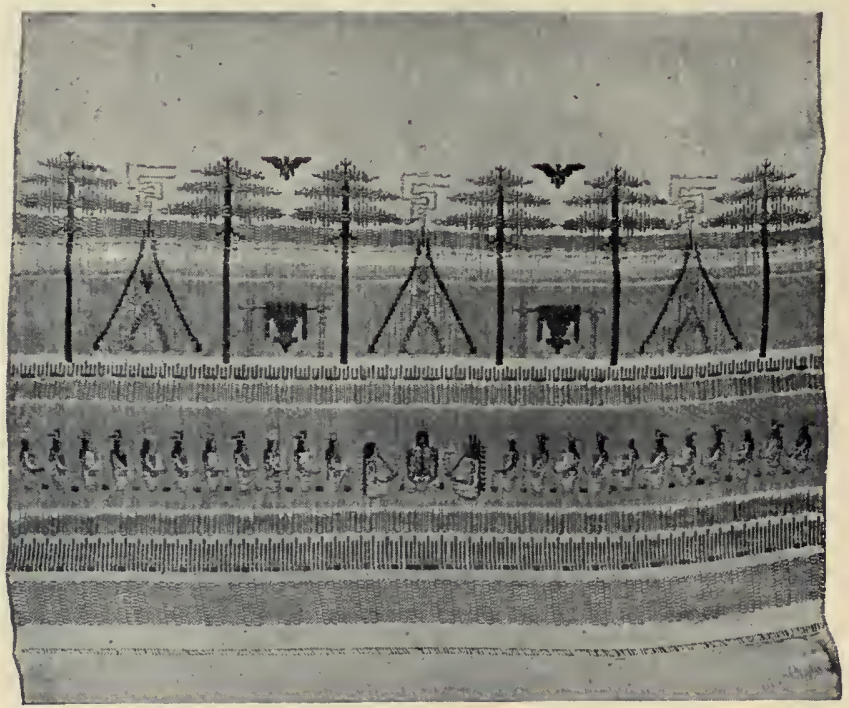

WINDOW HANGING

Designed for the Massachusetts Building, Jamestown Exposition, 1907. Hand-woven by blind women in the Art Fabric Shop of the Massachusetts Commission for the Blind

Even then the eyes might have been saved if the right germicide had been used.

At last, however, knowledge about this disease is spreading so fast that different states are making laws for the protection of the babies.

Connecticut, Michigan, Massachusetts, Maryland, Ohio, and other states have special state commissions for the 
blind, and each of these commissions exists for the sake of doing three things :

I. To educate the public for the saving of sight.

2. To start and carry on enterprises that will give work to those who cannot see : broom-making, basket-making, chaircaning, weaving, typewriting, mattress-making and pillowmaking, upholstering, massage, etc.

3. To provide home teachers for those who become blind after they are full-grown, and in this way to lighten their affliction.

The state commission of Ohio also gives definite advice for the benefit of every baby born.

\section{Directions for the Treatment of Babies' Eyes}

"As soon as the baby is born, the midwife must carefully clean the eyelids with water that has been boiled, using a separate soft linen cloth or clean absorbent cotton for each eye. ${ }^{1}$ She should wipe the lids from the nose outward, without opening the lids. Then the eyelids should be separated, and two drops of one per cent solution of silver nitrate dropped in each eye. A dropper must be used which is employed for no other purpose. Nothing that is not perfectly clean should touch the baby's eyes. If the baby's eyes get red, if a drop of matter appears between the eyelids or in the corner of the eye, a physician should be called. Do not delay in procuring treatment, as the eyes can only be saved by applying proper remedies at once."

The germicide needed kills the microbes if they chance to be in the eyes, while at the same time it does no harm to the eye if the microbes are not there. Nevertheless, it

1 That one eye may not infect the other. 
is such a powerful remedy that it should only be used on a doctor's prescription.

Warnings from doctors and scientists are producing results ; education is doing its work ; and more care is now taken of the eyes of our babies than ever before since eyes began to suffer.

In the meantime, while knowledge is spreading, let us not forget that microbes which bring this particular kind of blindness do not injure eyesight alone. They destroy eyes for the simple reason that when they get into the tender tissues of the eye, they find themselves in a place where they can multiply fast; and as they multiply they work their way along, scarring and destroying tissue as they go.

Fortunately these microbes make no impression whatever on the thick outside skin of the body; neither do they enter a cracked place in the skin; neither do they travel in the blood stream here and there. Instead, their one power of doing harm is after they have been lodged on any delicate, moist membrane. There they destroy as fast as they multiply.

From the starting point they spread from membrane to membrane of the organs of the body, and as they travel we say: "The disease is making headway. The inflammation is spreading." It does indeed make headway, for the advancing hosts scar all the tissues within reach, then move on to other regions for fresh supply: They move as a blight from one tissue to any other which may be directly connected with it, and wherever they go the doctor's remark is, "I find. serious inflammation." He speaks of inflammation of the heart, inflammation of the kidneys, inflammation of the joints, inflammation of this part and that, and over and over again the cause is the same - gonococcus microbes have reached the place and are scarring it.

Dr. Morehead speaks of the "snakiness" of the disease. He 
says it often lies in wait for years, then unexpectedly brings destruction to a man or perchance to his dearest friend.

One such case was supposed to be thoroughly healed; not a sign of the trouble had shown itself for six years. The man supposed he was perfectly well, when, without warning, he infected his own eyes with those microbes that bring blindness. "At the same time all his joints became involved, as well as the tendon sheaths of one foot. The microbes were obtained from the discharges of the eye, proving the real nature of the infection."

It is such cases as these that led Dr. Wilson, of the University of Pennsylvania, to answer his students as he did. They asked, "Can this disease be cured, and can a patient be sure that he is cured?" His answer was, "To the first question, 'yes,' and to the second, certainly, 'no'."

This disease has the same source as syphilis - immoral living. It is not the same disease, however, and, as we have seen, it manifests itself in different ways. We understand, then, the need of prevention through right living. We also understand why city after city is forbidding the use of the public roller towel, and we are not surprised that traveling men who spend so much time in public places are learning to carry their own towels with them. They were frightened into this in one place by the true report that "at least three traveling men had to give up their positions recently on account of infection from this source."

\section{Rules of Prevention}

I. Never use a towel or handkerchief that others have used.

2. Never put your fingers to your eyes unless you have just washed your hands; use a clean handkerchief or a bit of clean cloth to wipe out the corners of your eyes. 
3. Never use a public bathtub until it has been washed out thoroughly. Do not let the skin of your body touch the seat in a public toilet; cover it first with cloth or paper.

4. Never let the moist membrane of any diseased person touch you. There may be death in the touch.

5. Never sleep between sheets or on pillow slips that have not been washed after being used by others.

6. When sleeping away from home, in steamboat, car, or hotel, never let the blankets touch the body. These blankets are not washed after each use, as are the sheets. Always keep the fresh sheets against the face.

Already society tries to protect itself against smallpox and leprosy, against whooping cough, measles, scarlet fever, tuberculosis, typhoid fever, yellow fever, and other communicable diseases. And the modern movement aims to save family life from the two diseases mentioned in the last chapter and in this one. Students of the present situation tell us that the prevention of these two diseases is, in fact, the most important hygienic duty which faces the present generation, and that the safety of the nation rests on the ability of the young to understand the danger and to save themselves and their descendants through the power of right living and through their knowledge of facts.

The rules just given have to do with the risk of passing disease from person to person through the power of disease microbes. In addition, there is another risk which intelligence and will power must control - a risk which faces humanity through the power of inheritance and through the curse of feeble-mindedness.

In reading the next chapter, recall Dr. Bezzola's statistics about alcohol, germ cells, and feeble-mindedness as given in Chapter XVII. 


\section{CHAPTER XXV}

\section{SAFETY FROM FEEBLE-MINDEDNESS}

For the sake of studying the matter of feeble-mindedness at first hand, Dr. David Starr Jordan visited the Valley of Aosta, Italy, four times - in I88I, I883, I900, and I9IO.

After the first visit he wrote: "Cretins ${ }^{1}$ were seen on the streets everywhere and on the roads which lead to Aosta. Everywhere were these feeble little people, with silly faces and sickening smiles, incapable of taking care of themselves, and all disfigured by the goiter at the neck. Not every person with the goiter is an idiot, but every idiot has the goiter." . . . "In fair weather the roads about the city are lined with these awful human beings - human beings with less intelligence than the goose, with less decency than the pig. The asylum for cretins in Aosta is a veritable chamber of horrors." 2

In his book, Dr. Jordan emphasizes the following facts about cretinism :

I. It is found nowhere save in mountainous districts.

2. It is connected with disease of the thyroid gland, as also is goiter. No person with healthy thyroid glands ever has goiter or is ever a cretin.

3. It may be passed on from ancestor to descendant, according to the laws of inheritance.

Now it was because certain inhabitants of Aosta appreciated the point about inheritance that the tide turned at last and

${ }^{1}$ See "The Heredity of Richard Roe," by David Starr Jordan.

2. A cretin is a special kind of idiot, found chiefly in the Alps and having special bodily deformities. 
cretins began to slip out of sight at Aosta. Dr. Jordan discovered this fact in 1910. He had gone to the place expecting to find conditions about as they were when he was there before. But, "to my surprise," he says, "I was unable for some time to find a single cretin or even anybody who knew the meaning of the word.".

By asking questions, however, he soon learned that, about twenty years before, Aosta had put all its old poor people into asylums. It also appeared that gradually all the cretins had been put there too - the men in one part of the establishment, the women in the other. The two groups were kept absolutely separate - no mixing and mating ever being allowed. As a result, in no case was there any second generation. Those cretins and goitrous persons had no descendants to inherit their woe. They were the last of their kind. So true was this that, as Dr. Jordan writes, "there is but one cretin left — an old woman four feet high, who has the intelligence and, for that matter, the manners of a lap dog, very affectionate but without any mental capacity." He goes on to say that he visited the orphan asylum of Aosta and found " every child bright and alert, without a touch of goiter or of cretinism"; that he "inspected beggars standing in rows at the railway station, weak, inconsequential, useless, most of them, but not a cretin among them." The truth of course remains, that if healthy people live in conditions which bring disease to the thyroid gland, they will suffer accordingly ; but this is a different matter from beginning life as an idiot who is a cretin.

But to come nearer home. Turn from cretins in Italy and Switzerland to the feeble-minded in other lands. Dr. Hurty did this one day in Indiana. He was visiting an institution which admits only those who have feeble brains of one sort or another. 
As he sat in the gallery with the superintendent, he "watched the inmates solemnly walk through square dances." Writing about it afterwards, he said: "A young man at the piano attracted my attention on account of his firm touch and excellent execution. 'He is an inmate,' said the superintendent. 'He can play the music of the great composers quite well and has composed several good waltzes. $\mathrm{He}$ is a graduate of one of our minor colleges, yet he is an imbecile and suffers from emotional insanity. A strong attendant sits by his side, ever watchful to restrain him.' 'What is his heredity ?' I asked. 'That is the point,' answered the superintendent. 'His mother is feeble-minded, and his father died in the Central Insane Hospital. He had a sister in the idiot asylum." " Then Dr. Hurty adds: "Defective people curse the day they were born, and this man curses his parents. Almost every man you find with an hereditary infirmity curses the day of his birth."

In the United States alone we have I 50,000 feeble-minded persons. Some have intelligence enough to know they are blighted, to know whence the blight comes, and to fling out hatred and curses against their ancestors who doomed them. These are called the feeble-minded. They have some intelligence, some ability to think and to reason. But below them in mental rank, unable either to think or to reason, unable so much as to curse their fate and their ancestors, are the hopeless ranks of imbeciles and idiots.

Feeble-mindedness, imbecility, and idiocy - these are the descending grades, although, in speaking, people do not always keep them apart. And between the grades there is every shade of mental weakness.

In Vineland, New Jersey, 400 defective persons are gathered in what is called "a great human laboratory." 
Their ages run all the way from five to sixty years. Bodies young and bodies old are there, bodies large and bodies small, bodies strong and bodies weak. But among the entire 400 not a single brain is either keen enough or strong enough or mature enough to meet the requirements of everyday life. Each is so far below the normal human standard that it cannot be trusted to care for the body to which it belongs - incurably weak-minded, every one of them.

These people are divided into groups, each group with its caretaker. They are lodged in twenty-five different buildings. A schoolhouse is here, a merry-go-round there; barns in this place, broad fields under cultivation yonder; shops and a zoölogical garden, groves, and playgrounds - everything is provided for the comfort of these 400 mentally weak children. Moreover, each is trained to do something for the welfare of the institution itself. Some can do more, some less, according to the different grades of feeble-mindedness. And it is with these defective people that scientists are just now doing some of their most notable work.

Years ago, as they looked into the dull and stupid faces of feeble-minded people, they began to ask, "Has this dull child any dull ancestors ?" And merely to ask the question was enough. Over and over again the prompt answer came back, "Yes indeed, this dull child has several dull ancestors."

This was the beginning of the modern movement. Since that time family records have been made out in the shape of charts. Facts about parents, grandparents, and great-grandparents have been put in proper order; brothers, sisters, uncles, cousins, and aunts have supplied other facts; and from the midst of these ancestors and descendants the old story of cause and effect has been told again and again. In each family, ancestors who were feeble-minded or alcoholic or 
diseased through immorality have seemed to raise their heads and say: "Here we are. We had tainted blood. We passed our curse on."

Study these charts. They were made up from records kept in the Vineland institution. Some of them carry the family line back from son to father for five generations, while each

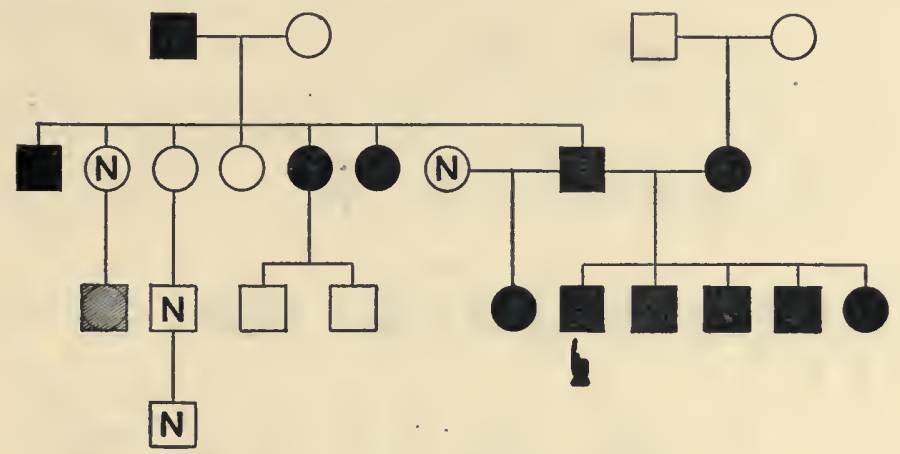

\section{INHERITANCE OF FEEBLE-MINDEDNESS}

Squares represent males; circles, females. Black means feeble-minded; white with $\mathrm{N}$ in it means normal; without $\mathrm{N}$ it means no data. When striated they indicate some condition worthy of note. A added means alcoholic; $T$ means tuberculous. The hand points to the individual whose ancestry is studied. In this case notice that both parents were feeble-minded and that the man had three feeble-minded brothers and one feeble-minded sister. Notice also that the grandfather on the father's side was feeble-minded. (From "Heredity as a Factor in the Problem of the Feebleminded Child," by H. H. Goddard)

one shows what fathers and mothers and grandparents have done for their descendants. Surely no disaster is greater than that of being the descendant of feeble-minded ancestors. ${ }^{1}$

1 Dr. Ellis says : "Feeble-mindedness is an absolute dead weight on the race; it is an evil that is unmitigated. The unquestionable fact that in all degrees it is highly inheritable renders it a deteriorating poison to the race; it depreciates the whole quality of a people." Also, "it is useless to work for the coming of a better race if we impose upon it the task of breaking the fetters its fathers have forged." 
Dr. Goddard proves this in his history of the Kallikak family. ${ }^{1}$ Here we find two distinct kinds of mental inheritance. They run side by side from generation to generation for one hundred fifty years. And, strange to say, the same man stands at the head of both lines. He was a healthy young soldier who fought in the American Revolution.

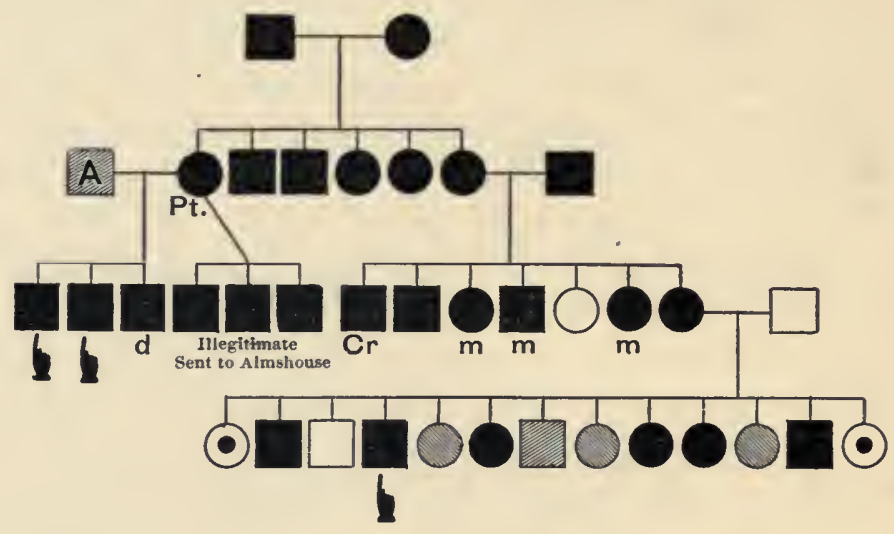

Alcohol AND FeEble-Mindedness

Locate the alcoholic man. Notice that his wife was feeble-minded, that she was the daughter of feeble-minded parents, that she had six feeble-minded sons and five brothers and sisters who were feeble-minded. (From "Heredity as a Factor in the Problem of the Feeble-minded Child," by H. H. Goddard)

Before the fighting began, he had one son. But, sad to say, the boy's mother was feeble-minded. So also was the boy himself. He inherited the calamity from his mother. Still he grew to manhood, was married, became the ancestor of children and of children's children, until, up to the present time, that feeble-minded son of the feeble-minded mother has

1 Out of kindness to the living members of the family, the true name is not given. Kallikak is a name made up for the occasion. It is believed that no other human beings are known by the same combination of letters. 
had altogether 480 descendants. Of these, 47 grew up to be normal, healthy people, while I 43 have been or now are feebleminded. Facts are lacking about the rest of the descendants.

This is the established record of one line of the Kallikak family. It brings out the fact that a feeble-minded mother may stamp successive generations of human beings with the misfortune of her own mental likeness.

The second line of inheritance in the same Kallikak family shows an entirely different record. And here again the explanation lies with the mother who, with the selfsame father, stands at the head of her line.

It seems that after the war was over, the soldier married a healthy, clear-headed woman of stock as fine as his own. They had children and children's children, until the total number of their descendants has now increased to 496.

Among these none have been feeble-minded. All have been normal, vigorous, worth-while people, honored and beloved and useful in all parts of the country.

In view of this double record it is easy to believe the statement that feeble-mindedness stands in line with everything else that is inherited. We are now told that if feebleminded people become parents, their.affliction may reach their own descendants in remote generations. In an average number of cases the inheritance will move along as follows :

I. If both parents are feeble-minded, all the children will be feeble-minded. This law never fails to work itself out.

2. If both parents are normal, and if neither of them has had any feeble-minded ancestors, all the children will be normal, and not one of them will be able to pass feeblemindedness on to the next generation.

3. If one of the parents is feeble-minded and the other is normal with no feeble-minded ancestor, their children will 
not be feeble-minded, but they will be able to pass feeblemindedness on to their descendants. ${ }^{1}$

In Vineland these facts of inheritance guide the men and women who are in charge. The result is that the feeble-minded persons of the place are kept as separate as are the cretins of Aosta. Elsewhere in the world they are not always separated. Often they receive some training and then are sent out into the world to shift for themselves.

It is at this point that danger threatens the next generation, for these half-trained, feeble-minded people are feebleminded still. As such they are able to pass their affliction on to later generations. This must be prevented.

If the Vineland plan were carried out everywhere, and if alcohol and germ diseases were not allowed to work havoc with germ cells, feeble-minded people would soon be as unknown in the United States and elsewhere as are the cretins in Aosta.

This is the gospel of prevention which modern science preaches.

As we know, however, we cannot altogether separate physical inheritance from the power of environment. The two have joined hands, and they travel together. Together also they help or harm both the body and the brain.

The next chapter gives a bit of history about the effect of environment on the physical well-being of generations of children.

1 In the Kallikak family the feeble-minded mother was responsible for all those feeble-minded descendants; but, since she was feeble-minded, and therefore irresponsible, the weight of the responsibility rests with the father, who chose her as the mother of his first-born son. 


\section{CHAPTER XXVI}

\section{OVERWORK FOR CHILDREN ONE HUNDRED YEARS AGO AND NOW}

In England one hundred years ago certain groups of children were living under appalling conditions. Cotton mills had been established, and the small fingers of little children were large enough to move this rod here, that rod there; to tie broken threads; to attend to the looms and the flying shuttles. They could indeed do part of the work quite as well as older people with stiffer fingers. So the children were in the mills, not because they liked it, not because their parents wished it, but because there was so little money in the family that even the youngest member of it had to earn what he could. Hunger and misery had joined hands. They had forced the children into the factories and the mills.

The ages of these children ranged from five to fifteen years, and even in the best of the places the youngest workers were kept busy from six in the morning until seven at night. They were supposed to do their studying (if they did any) in the evening after working hours were over. No one gave attention to the fact that minds cannot work when bodies are overtired.

But this was not the worst. There were still pauper children from the workhouse. Mill owners wished all the cheap service they could get. At the same time the managers of the poorhouse were only too glad to rid themselves of dependent children, regardless of consequences. So it came about 
that when mill owners needed more helpers, they went to the poorhouse for them. And when the order came, the caretakers of the place packed the children into wagons or canal boats and sent them off to be inspected. Having arrived, these children were put into cellars, - dark, damp, unwholesome, _ and there the mill men came with lighted lanterns to examine them. Height, weight, size, and shape were taken into account, "and the bargain was struck." It was really a purchase of children by the wagon load from their poorhouse guardians. Very little money was paid for these loads of small workers, but at least, henceforth, the poorhouse itself would not have to support them. As for wages, they received none whatever. They worked " sixteen hours at a stretch by day and by night. They slept by turns and relays in beds that were never allowed to cool, one set being sent to bed as soon as the others had gone to their toil."

Robert Blincoe describes his own experiences. He says he was sent to the place when he was seven years old, and that children and pigs shared the same food, the pigs being fed first, because they grunted so loud that they had to be quieted. When fattening time came for the pigs, they received "meat balls and dumplings" with their other food. The children never had any fattening time. They were always hungry, and they wanted dumplings, too. To get them they " used to slip away and slyly steal as many as possible, hastening away with them to a hiding place where they were eagerly devoured."

But it seems the pigs learned to keep "a sharp lookout, and the moment they ascertained the approach of the halffamished children, they set up so loud a chorus of snorts and grunts that it was heard in the kitchen, when out rushed the 
swineherd armed with a whip." Children were scattered, pigs were protected, and the contest came to an end.

No wonder those children tried to run away. "To prevent this, all who were suspected of such a tendency had irons riveted on their ankles with long links reaching up to the hips. In these chains they were compelled to work and sleep, young women and girls as well as boys." 1 Although this cruelty was carried on under cover, as it were, still facts leaked out by degrees. People began to get excited and to demand that something be done to save the children. One by one, earnest men and women took the matter up. They said children must not "be used up as the cheapest raw material in the market."

In 1799 and 1800 , as if to help the movement along, there came a sweeping epidemic. It traveled from factory to factory in Manchester and throughout the regions about the city. Everywhere it was the children who suffered most and died in largest numbers. Doctors looked for causes and said that "overwork, scant and poor food, wretched clothing, bad ventilation, and overcrowding, especially among the children," explained it all.

The result of the agitation was that even the British government bestirred itself. It passed a law that these children should not work over twelve hours a day, and that they should be clothed and sent to school and also have religious teaching.

After this, conditions were somewhat better; nevertheless, from then until now, in every country, certain groups of children have been overworked, underfed, and wretchedly housed. Take for example what is happening even in America, and even in the twentieth century.

1 For full description see "The Bitter Cry of the Children," by John Spargo. 
In I9I $2 \mathrm{Mr}$. Claxton wrote: "I have seen children under ten years of age working their lives away in the mills. Their pale faces haunt me still. I saw little boys eight years old drinking black coffee at midnight to keep awake until the end of their shift at four or five o'clock the next morning. Then they went out of the hot, steaming, noisy mill into the

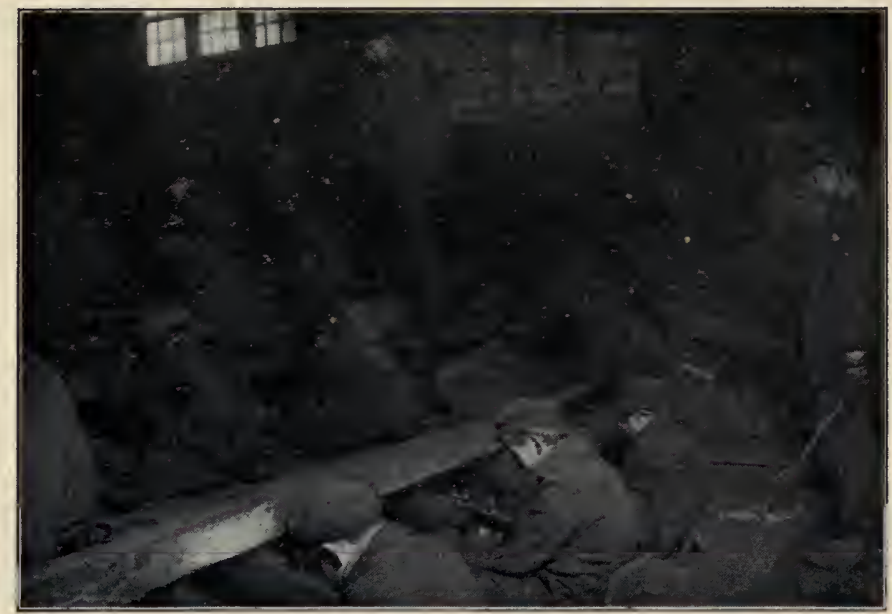

Boys of Fourteen working in the Breaker of a Pennsylvania Coal Mine

They work in this position for nine hours a day, at an average wage of $\$ 4.50$ a week. Their work is to pick out pieces of slate and stone from the coal as it moves through a chute over which they sit. (From H. M. Todd)

cold air of the morning to their homes, probably for a little fitful sleep and a joyless day, only to come back at night and grind again through the long dark hours."

Mrs. Florence Kelley describes the work of small boys "in the greatest canning factory in this country, just out of Chicago." They sit for "fourteen hours a day on a shelf in mid-air, every boy crooking his back and compressing his 
lungs" because "the bright eyes of these boys must see any defect in the lids of tomato cans and milk cans coming down in a procession." She says "they were constantly cutting themselves, crippling their hands, and cutting off the tops of their fingers in this work, because they had to seize these sharpedged things and take them out of the procession of cans if there was any defect in the lid. At the end of the fourteen hours of crouching on this wretched shelf the boys were so tired that they often could not drag themselves home, but. slept in the fields near by and went back to their work the next day without ever having gone home, because they were too weary at the end of the work."

Mr. Potter says that in another place he himself " has seen children five, six, and seven years old working as laborers in American canneries fourteen hours a day." His investigators have also reported 45 children under twelve in one place, 50 in another ("including many small tots hardly able to walk"), 20 in another, working from eleven in the morning to half past ten at night, etc.

And child labor is not confined to the canneries. There are thousands of child workers who spend twelve and more hours a day in crowded city tenements making artificial flowers and willow plumes and tips to shoe strings. Others work in glass factories, coal mines, silk mills, cotton mills, cigarette factories, and similar places where each day's labor exhausts them. ${ }^{1}$

Just now, in the United States, there are about two million of these workers under sixteen years of age. They work while other children sleep and play. They do not know what it is to feel well rested, well fed, and joyous. And what about the children afterwards? people are asking. Does overwork do any real harm?

1 Even now laws are being made which will prevent all this. 
Miss Goldmark says that between 1830 and 1840 there was such a change in the appearance of factory people who

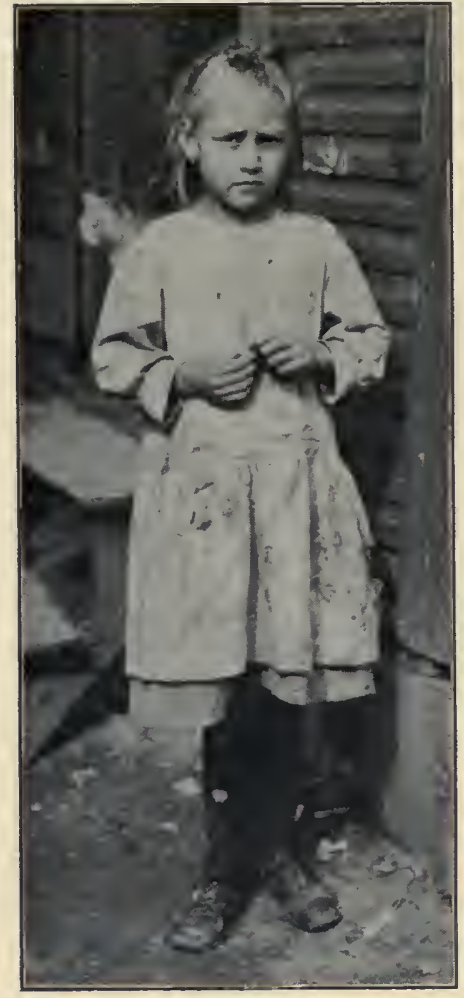

Seven-Year-Old Gulf-Coast WORKER

She "shucks oysters" for twenty-five cents a day had been overworking in England for two generations that eyewitnesses were horrified.' They saw "a race of pale, stunted, and emaciated creatures, irregular in their lives and dissolute in their habits" - a race "whose only hope seems to be that the race will die out in two or three generations."

Dr. Ellis speaks of the London weavers and draws our attention to a medical report which states that "though not originally a large race, it formerly contained healthy and well-made men." But, as the report gives it, "the whole race of them is rapidly descending to the size of Lilliputians; you could not raise a grenadier company amongst them." To a country that wishes to be ready for war at any time this decrease in size is a serious matter. And the same working and living conditions are producing the same result in other European countries.

1 See "Fatigue and Efficiency," by Josephine Goldmark. 
Miss Goldmark quotes from the report of a military examining physician in Germany on a certain factory district in I 89I. "In the factory villages, where every one works from youth up in the factories, almost all recruits were unfit for service, and I believe that, if this goes on, it will be useless to send recruiting commissions to these communities."

In the United States evil conditions have not existed long enough in any one place to prove much: In all lands, however, nations are beginning to act on the general belief that overworked and underfed children grow up to be inferior men and women, and that inferior men and women make inferior ancestors. The next chapter will show that steps toward race improvement began to be taken over a hundred years ago. 


\section{CHAPTER XXVII}

\section{THREE STEPS IN RACE IMPROVEMENT}

\section{Cleanliness}

Try to understand why the children were overworked and what their home surroundings were.

Machinery had been invented during the latter part of the eighteenth century; manufactures had increased; factories were built. It began to look as if great prosperity were at hand. Men, women, and children who formerly lived in the country came to town to get work in the factories. Here they were crowded together in small houses on narrow streets. In these places neither parents nor children knew what was meant by clean streets, clean air, clean houses, clean water, or clean food.

Naturally, therefore, the masses of the people lived in the midst of what we should call unspeakable surroundings. One such place was Bethnal Green, England. A report of conditions there was printed in 1848 , and on the basis of this report Dr. Ellis tells us that "many of the houses were huts, summerhouses, and sheds, never intended for use as houses"; that "there were thirty-three miles of streets and at least one hundred miles of byways," but that "only a few miles were sewered"; that "dust bins were unknown, slops thrown from the windows," and that "the streets were the common reservoirs for refuse of all kinds, sometimes accumulated in mountainous and evil-smelling heaps."

$\mathrm{He}$ also says that "the task of scavenging Bethnal Green, 
with its hundred and thirty-three miles of dwellings, was intrusted to thirteen decrepit old men," and that it took these men about three months to go over the ground each time.

Since disease microbes had not been discovered in those days, and since prevention was unknown, it is not strange that the people in Bethnal Green were attacked by these disease microbes and swept away by devastating epidemics. Ignorance explained it all ; yet ignorance does not weaken the power of the microbe nor interfere with the relation of cause and effect.

At last, knowledge about the need of cleanliness took the place of ignorance. Cities began to clean up. They paved their streets, cleared the rubbish away, built sewers, tried to get clean water, thought about getting clean air, and, in one way and another, took what was really the first step ${ }^{1}$ in the modern movement toward race improvement.

Nowadays this step has become a giant stride. London, New York, Chicago, Boston, and all other large cities are doing more or less in pulling down old tenements and putting up new ones that can be kept clean. They widen their streets and keep them not only swept but washed. For the sake of health and cleanliness some of them filter their drinking water, others bring it from distant lakes in the mountains. At the same time each city demands clean food as well as clean air, clean citizens as well as clean houses. Cleanliness has indeed become a modern health motto, although from the looks of some of our cities it is hard to believe this.

\section{Protection By LAw}

But even from the start those who strove for race improvement saw that cleanliness could not do everything. They saw

${ }^{1}$ Dr. Ellis writes of these steps in his book "The Problem of RaceRegeneration." 
that factory managers and mill owners still overworked and underpaid their fellow human beings, and they concluded that nothing could loosen the grasp of greed and of cruelty but laws stern enough to force mercy from the merciless. This, then, was the second step in race improvement.

Promptly a new order began. One law after another was passed, until now, in every civilized land, these laws grow more important every year. They decide how many hours each day one man may work for another, what protection he must have against dangerous machinery, what shall be paid in case of accident, how many holidays he must be granted, etc. Other laws in different places control the age at which children may begin to work by the day, the hours of their work, the amount of their wages, the kind of occupations they may or may not go into, their education while at work, and so on.

\section{Right Environment for the Children}

Each state is passing such laws every year, but even while the earliest ones were being enforced, those who watched results saw that laws against overwork were not enough that for the sake of real race improvement children must be supplied with right surroundings of every kind from the time they are born until they are grown... This was the third step.

It was precisely in this connection that the government of the United States, in I9I I, took a great step toward serving the children better. It then established what is known as the Children's Bureau. This bureau proposes to crush the forces that are ready to crush the children. In order to do this it intends to look up present conditions and report them to the public, to educate the same public, and to enforce more laws. 
And it is time all this was done. For years thoughtful people have noticed that, as a rule, children are good or bad, that they live or die, according to conditions about them - that they are cursed or blessed by their environment. ${ }^{1}$

Dr. Ellis says that seventy years ago, out of every thousand babies born in such cities as Manchester and Leeds, England, six hundred died before they were five years old. Their environment helped them to die. Dr. Ashby says : "In healthy children, among the well-to-do class, the mortality from measles is practically nil ; in the tubercular and wasted children to be found in workhouses, hospitals, and among the lower classes, the mortality is enormous, no disease being attended with more fatal results." Dr. Spargo gives a table of figures to show what effect environment has on the death-rate of babies.

Table showing Infantile Mortality from Eleven Given Causes, and the Estimated Influence of Poverty thereon

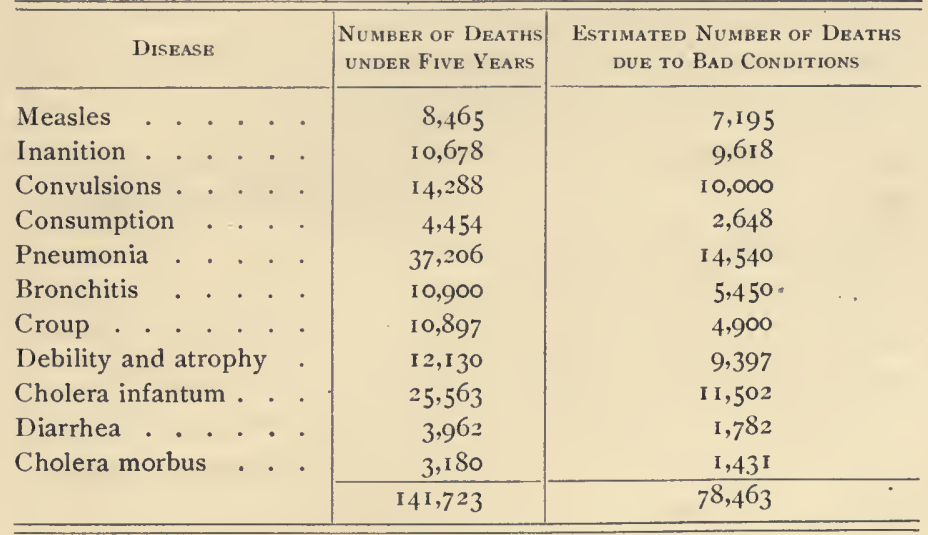

${ }^{1}$ Deep poverty is one of the worst of environments, because it is so inclusive in the harm it does. 
Make no effort to remember the figures in the two columns; they are merely an estimate. They do not claim to be exact, but they do point a great truth. They draw attention to the fact that when young children are surrounded by evil conditions, - by deep poverty and by the kind of environment which goes with such poverty, - they die of diseases from which they should have recovered.

In 1892 almost 1000 babies and children under the age of five died in Rochester, New York. At that time babies and grown folks too used whatever milk was brought to them by the dealers, for in those days no special attention was paid either to the quality of the milk or to its cleanness.

In 1904, however, there was a different death rate for the babies. Instead of 1000 , only 500 died that year; and yet since 1892 the population of the city had increased by 30,000 people. The explanation was at hand. It rested with the milk supply. Somewhere between 1892 and 1904 the Health Department of Rochester decided that the babies of Rochester should have clean milk for their everyday diet. Thereafter they had it, and everybody acknowledged that clean milk did more than any other one thing to cut the death rate in two. They said that no part of the environment is more important for babies than nourishment. ${ }^{1}$

Students of living conditions are saying more and more positively that, for, the good of the race, every kind of environment for the children must be properly looked after. They are also saying that even environment will not do everything. It is for this reason that they have taken their final step in race improvement, to the study of which we now turn.

${ }^{1}$ For full description of the clean-milk crusade in Rochester see " Town and City," chap. xx. 


\section{CHAPTER XXVIII}

\section{THE FINAL STEP, OR RACE REGENERATION}

In I9IO the state of Ohio had a population of about $4,700,000$, and at the same time it was supporting at public expense an army of 22,000 defective persons. Insane, feebleminded, epileptic, deaf and dumb and blind, criminal, immature, those ruined by alcohol - all these were counted in.

In 1908 the English Royal Commission estimated that there were about 150,000 notably defective persons in England and Wales. Now neither Great Britain nor Ohio is counted as in worse condition than other places. They simply point the fact that to-day every civilized state and country in the world is supporting handicapped people. More serious yet, statistics prove that the number of these handicapped persons is increasing by leaps and bounds each year. This last fact proves two points:

I. We are kind to the present generation, and we show it by taking good care of those who are defective among us.

2. We are outrageously unkind and carelessly cruel to the next generation, because, in thousands upon thousands of cases, we let the defects of one generation go on to the next by means of inheritance.

In view of this condition many of those who love their fellow men are now saying that every inheritable curse should die with the man or the woman who has it. They say that, in addition to the three steps given in the last chapter, a final 
step must be taken. It is stated as a command. It is the fourth great step in the race-improvement series. Protect the children before they are born.

\section{Protection of Children before Birth}

This step leads humanity into a new road, and the road itself leads to race regeneration.

Heretofore men and women have traveled the only road they knew. They have lived and multiplied and passed on the stream of life in ignorance of conditions affecting the welfare of their descendants. By the laws of the struggle for existence and the survival of the fit, the most unfit died in childhood. The rest lived to become ancestors. As a result, until lately each generation contained about the same proportion of healthy and efficient people.

This course of events continued for many ages. But a change came. Machines were invented. Men and women trooped in from the country to the factories and the mills of the cities. There they were overworked and underfed. For generations children and their children's children did the same kind of work, lived in the same deadly environment, endured the same cruelties. And each generation had less vigor than the generation that went before. Because their ancestors had become inferior, whole villages suffered.

Among these people disease microbes now made havoc. They killed thousands who should have been vigorous enough to escape. And, worst of all, no one knew either the cause of the death rate or the means of its prevention.

When matters were at this point, in 1865 , while Pasteur. studied silkworms in France, he discovered microscopic creatures that carried disease from worm to worm. ${ }^{1}$ "

1 For full description see "Town and City," chap. xxi. 
Since his time other men have not only discovered other disease microbes, but have shown us how to escape them, and it is this set of microbe discoveries that has brought us at last to the parting of the ways.

In studying records of the past we find that during recent years there has been an enormous increase in the numbers of feeble-minded, insane, epileptic, criminal, deaf and dumb and blind, and those ruined by alcohol, by overwork, and by unyielding chronic disease.

When we ask for an explanation of this, and when we study statistics, we see that because we have kind hearts, and because, in these days, we know how to save people from disease microbes, we have for years, innocently enough, been helping on the misfortunes of the race. In the struggle for existence we who are the fit have spent time and strength and money in keeping the unfit alive. We have lengthened the lives of our degenerates and maintained them in comfort. ${ }^{1}$ This we should have done. At the same time, however, we have allowed these same degenerate people to become ancestors of others like themselves. This we should not have done. To-day our asylums, our prisons, and our hospitals are caring for multitudes of defective descendants of those who should have been as carefully guarded as were the cretins of Aosta.

It is this situation which compels us to study the old road as we have just been doing, and helps us to understand why we must travel the new road - a road dedicated not alone to this generation but also to the next generation.

Common sense tells us that if we step across from the old road to the new, - that is, if, from now on, we heed the

1 Dr. Morrow has said that during the past twenty years "the life of the insane has been increased eight years, while that of the general population has been increased but four and a half years." He says "this is doubtless true of other defectives." 
command of reason and protect children before they are born, - we shall be able to change the entire outlook for the race within two or three generations.

If we succeed in doing this, those who live in the future will have the chance to be as surprised as Dr. Jordan was when he went to Aosta. They will read about the defectives of the twentieth century, will look hither and thither for their descendants, and when they ask what has become of them, answer will be made, "They have ceased to be; practical application of the laws of race regeneration saved them."

If now we ask what race regeneration really means, we shall be told that children have the right to be well born, and that men and woman who are so defective as to be unfit must not be allowed to become ancestors. And this is the meaning of race regeneration.

It is a matter of securing better descendants by taking the laws of inheritance into account. It is an obligation which commands each generation to pass on to future generations the best it has received, and to let its worst inheritance die with itself.

The history of the human race does indeed make it plain that a worthy line of ancestors is more to be desired than gold or lands or worldly position of any sort. It proves that right parentage is the noblest gift which one generation may offer to another.

Each of us carries his own ancestral standard through life. Each received this standard from men and women who are ranged back of us in endless rows. If the standard was high when it came to us, let us pass it on just as high to those who are to come after. If it tottered when we received it, let us so conduct our lives that it may be straightened up a little and be carried higher rather than lower by the next generation. 


\section{QUESTIONS}

\section{Chapter I}

Give three reasons why a careful breeder is willing to pay high for his animals. Describe what a scientist might do if he knew certain definite facts about the ancestors of your neighbors. Mention some of the labels which he might nail to the doors. When was Jonathan Edwards born? What were his noted characteristics? In 1900 how many of his descendants had been located? Mention the occupations of some of them. Taken as a whole, what influence has the family of Jonathan Edwards had upon the world? What was the occupation of the first-recorded ancestor of the Jukes family? When and where was he born? What was his character? How many descendants have been traced? Mention some of their occupations. Who were obliged to support those members of the family who spent their time in prison and in the workhouse? How much has the Jukes family already cost the people of New York state? In what two ways are people cursed from birth? What does the chart show? In the United States what was the increase in population between $\mathbf{I} 800$ and 1900 ? What difference will it make in the outcome of things whether one kind of family or the other kind multiplies faster on the earth?

\section{Chapter II}

Mention two distinct kinds of pure-bred Andalusian fowls. When a black and a white Andalusian fowl were chosen to be ancestors of the next generation, what was the question about their descendants? What was the color of the chicks? Did it make any difference which parent was black, which white? Were the children hybrid or pure-bred? When both parents are pure-bred of the same kind, will their children be hybrid or pure-bred? Explain the illustration 
which shows color inheritance. 'Tell.which individuals in the illustration are pure-bred, which hybrid. If we know the color of Andalusian fowls, what can we always tell about their descendants ?

\section{Chapter III}

During the years from 1900 to $\mathbf{1} 905$ what small animals were receiving special study in the Zoölogical Laboratory of Harvard University? Why did Professor Castle keep them in this laboratory? Why did he do his main work with guinea pigs? In the case of small animals why is it easy to trace resemblances between faraway ancestors and present-day descendants? How many generations do guinea pigs have each year? Why does this give guinea pigs an advantage as helpers in answering questions about inheritance? Describe the guinea pig - its size, color, coat, etc. What did Dr. Castle learn about the way these characters are handed on from ancestor to descendant? Are the laws of inheritance the same with guinea pigs as with Andalusian fowls? At first sight, do they seem to be the same or different? When black guinea pigs were mated with albino white, what was the color of their children? How do we know that all the black guinea-pig children were hybrid and not pure-bred? Why were these hybrids black and not blue? Describe the illustration. What do we mean when we say that black is dominant and white recessive? Which color is dominant with Andalusian fowls? Besides color, what other characters move along by definite laws? With guinea pigs, which is dominant, rough coat or smooth coat? long hair or short hair? By knowing the laws, how can one secure the desired kinds of descendants?. Why are human beings interested in the laws of life? In what way is each person a bundle of combined characters? What did Dr. Forel discover about his own face? How does he explain the children of many a distinguished man?

\section{Chapter IV}

Who was Mendel ? What did he do in the gardens of the cloister at Brünn? How many different kinds of peas did he raise? For what was he searching? Mention some of the characters which he 
studied in pairs. What did he do about keeping the pollen of different plants separate? Why was he so careful? Which characters were dominant? Which were recessive? Was every character either dominant or recessive? For how many years did Mendel carry on his investigations? When did he write his important papers? What did these papers tell? What effect did the reading of his papers have on his audience? What happened to the papers afterwards? How long did they stay in the Brünn library? When did Mendel die? What was he heard to say many times before he died? What happened sixteen years after his death? What do modern scientists think about Mendel and his work? Which books take Mendel and his laws into account? In what way has his name stamped the whole subject of inheritance? State three of Mendel's laws as given. Compare these laws with those given in the two previous chapters. How did Mendel discover his laws? Do they apply best to animals or to plants?

\section{Chapter V}

In 1900 what did the National Association of British and Irish Millers decide to do? Who was chosen chief investigator? Mention some of the qualities of the different kinds of wheat he used. Describe Professor Biffen's work with these varieties. What success did he have? Describe the two fields of corn that grew side by side. What was it that made the difference in the yield of the two fields? What has Mr. Burbank done in corn raising? What about the value of his potatoes? Mention other vegetables and fruit that have been improved by using the laws of inheritance. What is the boll weevil? How does it damage the cotton crop? What has been done to save the cotton from this weevil? Describe the difference between the amaryllis of former times and the new one produced by Mr. Burbank. Describe his work with the poppy. How large a poppy blossom has he secured? What can he do with poppy-seed capsules? How did he change the daisy? What has he done to the thorn-covered cactus? What have breeders done in changing sheep? For what is the Jersey cow famous? Mention other kinds of cattle and the special quality for which they are bred. What does all this show about the modern evolution of plants and animals? 


\section{Chapter VI}

Where are horses found? What can be said about their resemblance and relation to each other? What is a fossil (see footnote)? In what special museum in New York City do we find large numbers of fossil bones? How are the horse bones grouped in the museum? So far as size is concerned, how do they progress? Speak of the difference between the largest horse skeleton and the smallest. If these were alive to-day, would they treat each other as friends or as strangers? What remarkable fact do the graded horse bones prove? How long did the small horse live before the large one? During that time, what changes took place in legs and jaw and skull bones? Describe the foot as it changed into a hoof. What part of the middle toe finally became the hoof? What became of the other toes? What sign of toe is there on the legs of a modern horse? Where are these splint bones? While the toe bones were changing, what happened to the jaw bones and the teeth of the horse? What explains the gap between the front teeth and the back teeth of a modern horse? When the smallest and earliest horse bones first came to light, what name was given to the little creature? Where have many fossil horse bones been found? What connections have been traced? How many sets of scientists are needed to explain buried bones? What does the geologist do? What does the paleontologist do? What do we learn from fossil bones?

Which set of bones gives the most straight-ahead, complete history of the animal? In what countries have fossil horse bones been found? Where does this best series come from? If a horse could think and talk, what might he say about his ancestors?

\section{Chapter VII}

Where did Darwin keep his angleworms? What did he know about their different senses? What questions did he ask himself about them? Why are angleworms studied at night? Describe their actions as Darwin saw them. When did Darwin's interest in angleworms begin? What does Darwin say about the matter? 
What are the two parts of the work of Darwin's life? How old was he when he began his shell collection? Describe his experience in collecting beetles in Cambridge. How old was he when he went to South America? What was his position on the Beagle? Describe the Beagle (see footnote). How long was Darwin away from England? What fossil discoveries did he make in South America? What difference was there between the size of the fossil bones and the size of the living creatures which Darwin found in South America? What is the general contrast in size between animals now living in South America and those in Africa? How do we know that South American animals were once as large as those now alive in Africa? What does history tell us about the horse in America when Columbus arrived? How do we know that horses were among the oldest inhabitants of America? What is proved by fossil remains found in Europe, Asia, and America? What theory explains the fact that animals of the same kind were living during the same era in all three continents; that is, how did they travel from continent to continent? In his study of animals and fossils, for what was Darwin constantly searching? Why did he gather facts so persistently?

\section{Chapter VIII}

Give the location of the Galápagos Islands. Describe the tortoise which Darwin found there. Describe the lizards. Of what kinds of animals did he find new species? Define species (see footnote). Where had Darwin seen other creatures of which these reminded him? What question did Darwin ask himself about these new species? When did the Beagle return to England? What collections did Darwin now have in hand? By the use of his collections what laws did he wish to find? What were some of the questions which he asked himself about both the earlier and the later kinds of animals ? In order to get more facts, what birds did he study, comparing them with each other? Describe some of the different kinds of pigeons. After studying each kind, what conclusion did Darwin come to? What is the common opinion of naturalists about pigeon ancestors? What did every intelligent bird breeder assure him ? How long did one breeder say it would take to produce any given feather? How 
long for head and neck? What does Darwin say about the work of sheep breeders in Saxony? What does Lord Sommerville say about the success of the breeders? Even before Mendel and Darwin lived, what two facts did breeders know about the relation of ancestors to descendants? When Darwin saw how man gets results by controlling ancestors, what did he wish to know about wild animals? What did he ask himself about other laws? How long did Darwin study this problem? What is the name of the book in which he tried to answer it? When was the book published? Describe the way it was received and the excitement it produced. Of those who read the book, who were most inclined to accept Darwin's theory? When did Darwin die?

\section{Chapter IX}

Describe what you yourself have seen in springtime, or else give the description in the first paragraph. How many elm seeds were there in one small heap? How many maple seeds in another? How many seeds with their parachutes were counted on one dandelion stalk? What is the condition of the woods in springtime? What can you say of the fate of fish eggs in every breeding spot? What proportion survive long enough to become fish and to pass life on to the next generation? What does Dr. Thompson say about the multiplication of the cod? So far as the ocean is concerned, what would be the result? Give Dr. 'Thompson's figures about the oyster. What is the first law of Darwin's five-linked chain? When there is such prodigality on every side, when all must find food or die, what kind of competition follows? Give Darwin's second great law. Even though it looks like a peaceful world, give some facts about the struggle for food and for existence that goes on constantly. If all eggs were allowed to hatch and if all young animals lived to old age, what would the result be? Mention some of the checks to the prodigality of nature. In the struggle for existence, which plants and animals have the poorest chance to live and become ancestors? What did Darwin notice about the size and strength of different animals in the same species? What is the third law in Darwin's chain? Show how this law worked when 
rain was withheld in South America. Speak of the birds in snowcovered Ohio one winter. Why did some live and others die? What happened in Plymouth, Pennsylvania, in 1885 ? Describe the result of the yellow-fever tests in Cuba in 1900 . What did Darwin say is sure to follow because of the law of variation? Which creatures will survive? Give the fourth law in the linked chain. Show how this law works itself out. What about long legs? strong claws? keen eyesight? What about power to go without water and to survive famine? How do we know that those who are best fitted to survive are not always the largest, tallest, strongest, etc. ? Give an illustration from the huge animals of South America. What about the English sparrow? Which birds best survive a storm? How can you explain the ears of the mole? Give the final, supreme law of Darwin's chain. What did Darwin believe about the ancestors of all the wild animals that live to-day; that is, how did he think they were selected? Apply the five-linked chain to last-year's codfish. Mention some of the points on which all scientists agree. Which of Darwin's statements do scientists accept with one accord? What did Darwin show about creative power?

\section{Chapter X}

Describe the gill-slits of a fish (see footnote). Why does a fish swim with its mouth open? If it should keep its mouth shut, what would result? How does a fish get its needed supply of oxygen? Why does a fish die when it is drawn from the water? Why do we die when we are held under water? In which embryos did scientists expect to find gill-slits? In which embryo do they always find gillslits? What is an embryo? Mention the different kinds of creatures that have gill-slits when they are in the embryo stage. When animals are to live out of water after birth, what additional apparatus. does the embryo have? Mention the rudiments of different animals. What is a rudiment? How did Darwin explain a rudiment? Describe the sacculina. How long does a sacculina live? Give Darwin's three statements about rudiments. When we find teeth in the upper jaw of an embryo calf, what do we know about its ancestors? When we find rudimentary legs under the flesh of a full-grown 
whale, what do we know about its ancestors? When we find gillslits in the embryo of any animal, what does this prove about its ancestors? Why is a rudiment called an " ancestral reminiscence"? Describe the modern whale. What do its rudimentary legs and its rudimentary teeth prove? What do its embryo gill-slits prove? Taken altogether, what do we learn about the history of ancestral whale life? What is structural evidence? Give Darwin's illustration. What is embryological evidence? Where do we find our geological evidence? What evidence does geography bring? What evidence comes from modern experiments? 'Taken altogether, what do the five kinds of evidence prove?

\section{Chapter XI}

How did a certain woman try to make sure that her child should be musical? Are children stamped by what the parents are in themselves or by what the parents compel themselves to do? How did the friend know that the daughter would be persistent and not musical? For how long a time did women in China continue to bind the feet of their daughters? During what part of life were the feet kept cramped? What effect did the binding have on the feet of the children of succeeding generations? What is an acquired character? (Fordefinition see footnote.) If a woman crimps her hair, what effect will this have on the hair of her children or of her children's children? In what way can curly hair be secured for one's descendants? Mention certain characters which may be acquired and which are not passed on by inheritance. Describe trees that are dwarfed in the gardens of Japan. How did they become so dwarfed? Judging by the appearance of the trees, what would one expect their descendants to be? In point of fact, is the condition of being dwarfed passed on by inheritance? When dogs, sheep, and horses have their tails cut off for successive generations, what effect does this have on the tails of their descendants? What is a mutation? Speak of the mutation that appeared in a herd of well-horned cattle in Paraguay in $177^{\circ}$. Why were the owners pleased with this hornless animal? What kind of descendants did it have? Why were the owners astonished at results? What does Darwin tell us 
about the origin of short-legged Ancon sheep? Why are these sheep particularly liked by sheep raisers? Where are they now found? Describe Mr. Poulton's family of cats. Describe the different members of the family of the six-fingered boy. What is meant by polydactylism? What does brachydactylism mean? Describe the case of the short-fingered family shown in the diagram. What do all these facts prove about any character which begins as a mutation? What is the difference between an acquired character and a mutation? If this mutation should give its owner any advantage in the struggle for existence, what would be the effect on succeeding generations?

\section{Chapter XII}

Give a few facts about the Hawaiian Islands (see footnote). Describe the different kinds of land shells that were found on these islands in 1852 - their color; size, etc. How long and how wide is the island of Oahu? What can you say about its mountain range and its valleys? How many species of the same family of shells did John Gulick find on Oahu alone? Just where did the different species live? What can you say about the traveling habits of these snails? What did John Gulick do that made his collection priceless afterwards? What does he say about his interest in the location of each shell? What did he discover about the numbers of species that were close together? As he gathered his shells and studied, compared, and labeled them, what did he notice about those that lived closest together? When he had arranged his shells according to the exact spot they came from, what further did he notice? What was the first question which he asked himself? What was the second question? How long afterwards did Dr. Gulick answer his own questions? How was it that nature acted like a careful breeder on Oahu? Give the first step in this process; the second step; the third step; the fourth step. Just why did each new group of descendants become slightly different from its own immediate ancestors? To make this plain, give the case of seven birds with beaks of different length. How is the average found (see footnote)? What can be said about this law of average in connection with snails? 
Give two reasons why there was such an extraordinary number of species of snails on Hawaii. When colony after colony had been started in this way, what should we expect to find in regard to their descendants? What does Dr. Gulick call any separation which prevents one colony from mating with another colony? What is geographic isolation? What is food isolation? What does genuine isolation of this sort result in? What sets of living creatures are controlled by the law of isolation?

\section{Chapter XIII}

In Kansas what special event marked the year 1862 ? What did one afflicted man write about his experience with potato bugs? Where did the ancestors of these beetles come from? When and where did they get their first taste of potatoes? What years are covered by Dr. Tower's history of the dispersal of Leptinotarsa decemlineata? What does this record show? What road did the beetles take in traveling from Illinois to Boston? Give the records for $1864, \mathbf{1} 865, \mathbf{1} 868, \mathbf{1} 87 \mathrm{I}, \mathbf{1} 874, \mathrm{I} 875$, and $\mathrm{I} 876$. How fast did the beetles travel? How long did it take them to make the journey? Why were the European nations anxious? What weapon did Europe use to save herself ? What was done in Germany and in France ? Describe what happened in 1876 . In this journey what did the beetles prove about their own environment? What one thing did they require? How much time do most potato bugs spend underground? What happens to them in the spring? Why does the farmer feel discouraged? What does he do? Compare the snails of Hawaii with the potato bugs of America: first, the number of species; second, the kinds of food; third, the methods of travel; fourth, the region covered by a single species of snails on Hawaii and by a single species of potato bugs in America. Put together in this way, what do these facts show? Tell what conditions would have been necessary in order to make many species instead of one species out of the potato bugs of America. 


\section{Chapter XIV}

How fast do Reptinotarsa decemlineata multiply? When does the egg-laying time come? Describe the process. How many eggs are laid in close succession? What is the entire number laid by one beetle? Why do the eggs have to be laid in separate sets? How many days are there between the laying of two successive sets? When do the larvæ begin to eat green things? How many days are required to turn a newly hatched larva into a full-grown beetle ready to lay eggs of its own? Where did Dr. Tower carry on his experiments? What did he already know about the starting point of every kind of beetle? What did he propose to find out about germ cells? In studying the matter of color, how many beetles did Dr. Tower secure? Where did they come from? When they reached Chicago, where did he put them? What about the temperature of each breeding place? During what years did Dr. Tower carry on his investigations? After eleven years what had he found out about the effect of heat and of cold on the color of the spots and stripes of the beetles? What did these experiments prove? What calamity overtook the beetles? Before they had been killed by the heat, what other experiments did Dr. Tower carry on? What did he suspect about germ cells being influenced by their environment? How many pairs of beetles did he choose in 1902 ? What did he do with them? How many eggs did they lay? What did he call this set? What did he do with those six beetles and all their eggs after that? How many additional eggs did these same beetles lay? What was this set called? What happened to many of the eggs and many of the larvæ of both Lot A and Lot B? How many full-grown beetles were produced by lots $\mathrm{A}$ and $\mathrm{B}$ ? (See footnote.) What was the scientific name of the parents of these beetles? Where had they been brought from in the first place? When beetles of this species are frightened, what do they do? When another şpecies, called Leptinotarsa mela nothorax, is frightened, what does it do? What was it that surprised Dr. Tower about this lot of beetles? What had the damp-heat environment done to them even before they had been laid as eggs? From the scientific point of view, what was the most notable part of Dr. Tower's work? 


\section{Chapter XV}

How many unfertilized frogs' eggs did Professor Bataillon use for the experiment described? What did he do with them? How soon did results begin to appear? How many of the eggs developed in normal fashion? How many of them finally turned themselves into tadpoles? Of these, how many lived to become real frogs? Describe the oldest of the three. How many cells has the amoba? How does it multiply? What can you say about the number of cells in all complex animals? Mention a few of the different kinds of cells and the kinds of work they do. Which cells are able to pass life along from one generation to the next? How much alike do the germ cells of different kinds of animals look? Mention some of the characters that are stored up for use and packed into their own particular germ cell. What is the great difference between germ cells and all other cells of the body? How much do they do for the welfare of the body to which they belong? What is the sole purpose of their existence? What happens to both the amœba and the germ cell if they become dry? Why is it easy to keep fish cells from drying up? What does a mass of fish eggs look like? For the benefit of the next generation, how long must germ cells stay in damp surroundings? In this respect what special advantage have fish and frogs? What is nature's arrangement for keeping embryo birds and reptiles moist while they develop? What two things is the albumen of the egg good for? What two things does the shell do? Why are not all animals (ourselves included) supplied with eggshells, then hatched out when the time comes?

\section{Chapter XVI}

During what period of their lives did Dr. Minot study developing chicks? How did he do this? At the end of the first day what change did he find? at the end of the second day? the third day? the fourth day? the fifth day? What was the condition of the chick after ten days of growing? From start to finish, in what does the whole process of growth consist? Mention the figures that follow each other after the first combined germ cell begins to 
divide. What can you say about the resemblance of different embryos in their earliest stages? As it grows, how does an animal in its eggshell get nourishment? When does an expanding chick make its way out of its shell ? How long is it from the time when a hen begins to sit on her eggs to the time when the chick is hatched ? When is an animal said to be oviparous? When an animal is born alive, what is it called? Before birth what supplies nourishment to the developing oviparous animal ? Describe the difference between the chick and the rabbit after birth. Mention the time it takes for various animals to develop. When do cells multiply fastest, before or after birth? What have surroundings to do with the welfare of young and growing creatures? What was it that made the difference in the size of the four young tadpoles? How much does a normal seven-pound baby gain during the first year of his life? How much does he gain during the second year? After that, how much until he is fourteen years old? What two things can a baby do from the start? What about the use of all five senses? Give a brief sketch of the progress of the baby from stage to stage. What does Dr. Minot call the first period of a baby's development? What has happened during this period? What does a baby do during its second period? Give what you can of Dr. Minot's description of an eight-months-old baby. When is a baby usually able to walk? What does Dr. Minot say about the importance of the health of the mothers?

\section{Chapter XVII}

How many eggs were in the incubator? Describe the appearance of the chicks when they were hatched. Altogether, how many chicks came from the eggs? What happened to the rest of them? How many chicks died within four days after the hatching? When investigators looked for an explanation of all this, what did they find? What conclusion did they come to about the effect of alcohol on chicks in their shells? What was Dr. Forel's own conclusion? Describe the two sets of tests carried on by Dr. Féré between the years 1894 and 1903 . How often was the same experiment repeated? What did the tests always show about the minds of the chicks? What seemed to be the matter with those that had endured 
the vapor of the alcohol? How did Dr. Stockard first give alcohol to his guinea pigs? What was his second attempt? Why did he stop giving it to them through a tube? Describe his copper tank. What does Dr. Stockard say about the guinea pigs in the copper tanks? How long did they usually stay in the tank ?' During the rest of the time what kind of air did the guinea pigs breathe? For how many days in a week, and for how many months, was this treatment kept up? What effect did the fumes have on the guinea pigs at first? In the course of a few weeks how did they behave? So far as the next generation yvas concerned, what were the four kinds of tests? When neither of the parents was treated with alcohol, how many of their children lived? When both parents were treated with alcohol, what was the fate of all their children ? How many families did Dr. Gordon study in which both father and mother used alcohol? How many children were there in these families? How many of these were epileptics? In twenty other families where the grandfather as well as both parents used alcohol, what was the condition of the offspring? How many family records did Dr. Demme investigate in Switzerland? Give the record of the children of the ten drinking families. Give the record of the ten abstaining families. What was Dr. Bezzola's occupation? When children were brought to the institution, what did he often hear about the parents? What census reports did he study? Why did he look up the birthdays of those 8196 feeble-minded persons? Which did Dr. Bezzola call the alcohol-rich periods in Switzerland? which the alcohol-poor months? Give the first point made by Dr. Bezzola's report; the second point. How much alcohol may a person take without running the risk of damaging a future child? What does Dr. Bezzola declare about this particular matter? What was his conclusion from the studies he made? Why should we refrain from blaming a feeble-minded person?

\section{Chapter XVIII}

What three questions did Dr. Gulick ask in i 897 ? Who received these questions? How many answers came back? What did Dr. Gulick do with these answers? What did the tables show about 
the age when special choices were made? What report did Dr. Gulick study in the Eleventh Census of the United States? What did he do next? What do the tables show about the average age of prisoners? What is the average duration of sentence of the American male prisoner? What, then, is the average age at which he enters prison? In closing, what does Dr. Gulick say about the age at which individuals take to criminal life? Which period of human life is most full of fateful import? 'When the era opens, what is the condition of the individual? When it ends, what has the child become? What kind of reading and study do boys most enjoy between the ages of fourteen and twenty? Why do many boys begin to smoke during this era? During which years does a girl grow more attractive - more womanly and gracious? What is the period of special instability? Why is it called the storm-and-stress period? What should receive special attention during the adolescent years? During what years is a man deciding his destiny? While he decides his own fate and forms his own habits, what is he doing for his descendants?

\section{Chapter XIX}

How many boys helped Dr. McKeever in his experiments? What were their ages? Why did Dr. McKeever need the help of these particular boys? What was he trying to decide about the use of tobacco? What machine did he use? What records does the sphygmograph keep? Where is it fastened to the body? On what does its needle make a record? When were the records taken? What did they explain? Give the first statement; the second statement. What does the first diagram show ? the second diagram? Compare these, line by line, with the third diagram. What does the heartbeat indicate about the changing feelings of the boy? What parts of the body are benefited when the heart makes its best record? Why are they benefited? What was done with the sphygmograph while the different records were being taken on the same boy? How long did this unusual vigor last? Then what happened? What is the objection to slow-moving blood and a low heart record? What parts of the body suffer? How long will the slow-pumping heart stay in charge of the slow-moving blood of the smoker? What 
will happen when he takes his next cigarette? How many cigarettes does the habitual smoker sometimes use a day? What can you say about the double character of tobacco? Describe the case of Dr. Kellogg's frogs. How much nicotine does it take to kill a frog? What was the fate of Homer Leslie? What is the one most injurious thing in tobacco? Describe what takes place when a man sets fire to his cigarette and smokes it. At what point do the nicotine and the smoke part company? What becomes of the smoke? Follow the journey of the nicotine. What occurs as soon as the nicotine in the blood stream reaches the heart? When Dr. Seaver studied the records of smokers and nonsmokers among the students at Yale, what did he learn about them? Give Dr. Meylan's conclusions. When ignorant people protest against these conclusions, what are the two horns of the dilemma which they have to choose between? Why does this chapter say so little about grown men who smoke? When does the smoking habit do a person most harm, before or after he is twenty-five years old? Tell what you can of Mr. Depew's story of his own smoking habit and how he broke it. In what way does the smoking habit of one generation harm the next generation? In what particular ways are sons apt to become like their fathers? What connection is there between the tobacco habit and the alcohol habit?

\section{Chapter XX}

Describe the case of the boy from India. What kind of help did the doctor say he must have during the operation? How was the blood sent across from the student to the small boy? How much blood did Charlie receive? What was the result? What does Sir Frederick Treves say about operating on drinkers? Describe the drinker mentioned in this chapter, or any other case which you yourself have seen. Describe the diagram. What is the order in which brain cells develop in the human embryo? Which cells are developed first? which last? which part of the brain does alcohol damage first? which part last? Describe the bottle that found its way into the schoolroom. What was in the bottle? Why was it in the schoolroom? On what does the success of the saloon business depend? In whom must the appetite for drink be created? Mention 
ways in which this kind of "missionary work" is done. What advantage is there in giving free treats to boys? If boys cannot be secured as drinkers, what will happen to the liquor business of the world? Where did Dr. Lambert go for his facts about all this? What made him decide to find out how old people generally are before they begin to drink? How many persons answered his questions? How many of the two hundred and fifty-nine persons began to use alcohol before the age of four? between the ages of six and twelve? between twelve and sixteen? between sixteen and twenty-one? between twenty-one and thirty? After thirty how many were there? What per cent of those who have the alcohol habit began to drink before they were twenty-one years old? If a boy is free from the habit until he is twenty-one, what are his chances?

\section{Chapter XXI}

Point out the vital difference between man and the huge animals of former times. How did the brain of the largest animals compare in size with the brain of the smallest man that lives to-day? Explain the size of man's brain by the five-linked chain of evolution. While the brain developed, what other useful part of man was also developing? In what ways did man now begin to help himself and his descendants? In order to understand man in his early condition, what part of modern civilization must we sweep away? Describe the conditions in which our earliest human ancestors lived. Mention one or two of the greatest early inventions. How is man supposed to have made his first fire? How important to the race was this discovery? What constituted the beginnings of architecture? What faculties of the mind did early man press into service? What was the beginning of our higher mathematics ? In all this what did each generation gain from the generation that went before? What do we mean by "social inheritance"? In addition to his physical inheritance and his social inheritance, in addition to his inventions and his discoveries, what did the spiritual part of man do for him ? So far as his past and his future are concerned, in what way is man superior to all other living creatures? What is it that gives man conscious power as he walks the earth? What does he know about 
the power of his own will? What is man willing to do for his fellow men? What is man's crown of evolution? What advantage is it to man to have a normal, well-trained brain ? In what way may a man's brain be a disadvantage to him? How does it happen that man is able to do himself more harm than can be done to itself by any other creature? Speak of the changes that have come about since men were scattered savages fighting each other. As groups grew larger, what notion also grew stronger? Who are the members of a family?

\section{Chapter XXII}

Why must such a book as this take the laws of family health into account? Why are people who live together in more danger from certain diseases than are those who live apart? Mention a few of the diseases that threaten those. who live closest together. Of what are towns and cities made up? On what does the future of every nation depend? What is an important motto of modern life? For the sake of this generation and the next, what two sets of laws must one know about? In former times what was a nation's watchword? What is the modern command? Why is the modern form of patriotism the nobler kind? How does a man prove that he is worthy of the crown which evolution has placed upon him?

\section{Chapter XXIII}

In what periodical was the account of the epidemic described by Dr. Schamberg? What happened on March 4, I9 I ? What blemish did one of the young men have? If an intelligent doctor had seen the sore, what would he have said about it? What occurred on March 25? How large did the sore become? When did the second girl discover her two sores? Where were they located? How many cases of the same kind followed each other through the months of March and April ? In each case what was the cause of the sore? What lesson did Dr. Schamberg say this epidemic should teach? Why was this special kind of sore worse than any other? What did it prove about the condition of the entire body? Under what conditions do the microbes of this sore go from person 
to person? When a cracked mucous membrane comes in contact with one of the sores, what happens at once? What is the condition of things after twelve hours? How long after the contact will the first sign of sore show itself? Why is this sore called the " mark of the devil"? As microbes multiply in the new place, what do they manufacture? What becomes of this poison? What does Dr. Forel say about the progress of this disease? How long may the disease stay latent in the body? Where may it appear later? What does it cause? What does Dr. Morrow say about this disease? What does Dr. Osler say? Where may mucous patches of the disease appear? Why is there so much agitation nowadays against the use of the public drinking cup? What is now used instead? In watching those who use a public drinking cup, what have you seen? If a public drinking cup must be used, what is the one safe way to drink from it? Mention some of the laws of protection. Of all the diseases which come to man, why is this the worst?

\section{Chapter XXIV}

Describe the case of the doctor on the night boat going from Boston to New York. What did the man know about the cause of his calamity? Describe Dr. Howard's case of the mother and the daughter who lost their eyesight. If the woman had known the facts, by what simple means might she have handled the sheets and the towels and yet have prevented the microbes from entering her eyes? About how many totally blind persons are there in the United States? About how many partially blind persons? About how many of them all have been made blind through the gonococcus microbes? When did these microbes enter their eyes and cause blindness? What does Dr. Neisser say about the conditions of this blindness in Germany? How true is the expression "blind from birth" ? In almost all cases, what is the condition of eyes at birth ? When does the blindness come? If the right medicine were used at once, what would be the result? What three things does every state commission for the blind propose to do? In treating the eyes of a newborn baby, what should be done first? Why is a separate cloth used for each eye? How is the medicine put into the eye? 
What is the medicine and how much of it is used? Why should everything be perfectly clean that touches the baby's eyes? Why should the dropper be used for no other purpose? (Lest microbes from a diseased eye get to the dropper and be passed on to some other person.) Mention some symptom which shows that the eyes of the baby are needing the care of a doctor. Why should the doctor be called at once? What does this particular medicine do to any gonococcus microbes that may be in the eye? If the eyes are free from these microbes, what objection is there to using the medicine? Why should the medicine be used only by the doctor's order? What progress is being made in the care of the eyes of babies? When these microbes reach the tender tissues of the eye, what do they do as they multiply? What impression do these microbes make on the thick skin of the body? Do they travel about in the blood stream of the body? When and where do they exercise their one power to do harm? How fast do they destroy any delicate, moist membrane? From the starting point where do they go? What does the doctor say as they travel from membrane to membrane? What do the advancing hosts of microbes do to the tissues? Name some of the organs of the body that are inflamed and scarred by these microbes. What reason has Dr. Morehead to speak of the "snakiness" of the disease? What two questions did students in the University of Pennsylvania ask Dr. Wilson? What was his answer? One after the other, mention all the rules of prevention you can think of. After each rule give the reason for it.

\section{Chapter XXV}

When did Dr. Jordan visit Aosta? In your own words describe what he found in Aosta in $\mathrm{I} 88 \mathrm{I}$. Where is cretinism found? Which gland is diseased in every cretin? By what laws is cretinism passed on from ancestor to descendant? Why was Dr. Jordan surprised when he visited Aosta in 1910? What had Aosta done with its cretins about twenty years before? So far as the next generation was concerned, what was the result of putting the cretins into asylums and keeping them separate? What does Dr. Jordan say about his search for cretins and his failure to find them? In closing his 
description what final fact does Dr. Jordan bring out? What did he say was the only way to get rid of a next generation of cretins ? Describe the young man at the piano, whom Dr. Hurty watched. From what kind of insanity did the superintendent say he suffered? Repeat the question which Dr. Hurty asked about the young man. What did the superintendent answer? How many feebleminded persons are there in the United States alone? What are the three terms which are applied to feeble-minded persons? Are there clearly marked distinctions between different kinds of feebleminded persons or do they grade into each other? How old are some patients in the Vineland institution? What is the condition of their bodies? What is the condition of their minds ? Tell a little of what is done for these mentally weak children. Years ago, when scientists looked into the stupid faces of feeble-minded persons, what question did they naturally ask themselves? When they looked up family records, what kind of ancestors did they find in each family? How far back does the history of the Kallikak family go? Why is the real name of the family not given to the public? Who was the first Kallikak described? In what war was he a soldier? What sort of woman, mentally, was the mother of his first son? What was the mental condition of that son? When this boy had grown to manhood, what kind of descendants did he himself have? Up to the present time how many descendants has he had? Of these how many have been normal, healthy people? How many have been or are now feeble-minded? Describe the woman whom the first Kallikak married after the war of the Revolution was over. What is the total number of their descendants? Mention some of the noble characteristics of these descendants. How many of them have been feeble-minded? In view of the double record of the descendants of the same man and the two different women, what do we learn about feeble-mindedness and inheritance? Give the laws that govern the inheritance of feeble-mindedness. How careful are the Vineland people to keep their feeble-minded men and women separated from each other? When a feebleminded person has received some training, why is it unwise to send him out into the world to shift for himself? If the Vineland plan were carried out all over the world, what would be the result? 


\section{Chapter XXVI}

Why were children working in the cotton mills of England one hundred years ago ? What were the ages of the children? When were they supposed to do their studying? Give facts about the pauper children who became workers at the mills. How long at a stretch did they work? What wages did they receive? What does Robert Blincoe say about his own experiences? How were children prevented from running away from the mills? What did earnest men and woman finally say about saving the children? What occurred in 1799 and 1800 to help the new movement along? Where did the epidemic spread? Who suffered most? What did doctors say was the cause of the high death rate of the children? In response to the agitation, what did the British government do? What effect did the law have on conditions of life for children? What does Mr. Claxton say about the condition of certain child workers in I9I 2 ? Give in your own words what Mrs. Kelley describes. What does Mr. Potter say he has seen? Mention some of the things which overworked children are known to make in crowded city tenements. What does Miss Goldmark say about the change in appearance of overworked people? What does Dr. Ellis say about the physical condition of overworked London weavers? What did a military examining physician find in Germany in $\mathrm{r} 89 \mathrm{I}$ ? What is the general belief about overwork which all nations are beginning to act upon?

\section{Chapter XXVII}

When was machinery invented? Why did it look as if great prosperity were at hand? Why did men, women, and children move into town? In what kind of surroundings did they often live? Describe the condition of Bethnal Green as given in 1848 . How many miles of dwellings did the town have? Who were the city scavengers? How long did it take the men to go over the ground once? Why were the inhabitants of Bethnal Green attacked by disease microbes? What did people know about disease microbes in those days? When knowledge began to take the place of ignorance, what did cities themselves begin to do? What was the first great 
step towards race improvement? In these days what are some cities doing in order to be clean? What is your own city doing in the line of keeping clean? When race-improvement people saw that cleanliness would not do everything, what did they also see was being done by factory managers and others? What was their conclusion about the need of laws to help the oppressed? What, then, was the second step taken in the direction of race improvement? Since protection by law is part of the new order, tell what some of these laws do to protect people. In addition to cleanliness and protection by law, what did people say must also be done in the matter of right surroundings for children? What, then, was the third step in race improvement called? In 19 I I what did the United States government do to help the children? What does the Children's Bureau propose to do? What have thoughtful people been noticing about the effect of environment on children? In Manchester, England, over seventy years ago, how many children out of every thousand died under five years of age? What helped them to die so young? What does Dr. Ashby say about the effect of measles on healthy children of well-to-do people ; that is, did many or few of their children die of measles? What about the result when children in the workhouses and such places had measles? Mention some of the diseases given in the table in which poverty had much to do with the death rate. To what fact do the figures of the table draw our attention? Describe the difference between the condition of the milk supply in Rochester in 1892 and that in 1904. What improvement in the death rate was there in 1904? What was the explanation of the changed death rate?

\section{Chapter XXVIII}

How large an army of defective persons was Ohio supporting in I9I0? Mention some of the kinds of defects included in the number. How does the condition in Ohio compare with that to be found elsewhere in the world? How do we prove that we are kind to the present generation? How do we know that we are unkind to the next generation? In view of this condition, what conclusion has been reached by those who love their fellow men? 
What, then, is the fourth great step in the race-improvement series? In past ages how much thought did people give to the welfare of their descendants? By what laws did those who were least fitted to survive die in their childhood? What effect did this have on the number of healthy and efficient people in each generation? Describe the change in living conditions which took place after many ages. What effect did inferior ancestors have on whole villages of descendants? Why were disease microbes now able to make havoc among these descendants? In those days how much did people know about prevention and the cause of the havoc? What great dis: covery did Pasteur make in 1865 ? What was he studying when he came upon disease microbes in the silkworm? Since his time what have other men discovered in the same direction? What, then, is it that has brought us to the parting of the ways? When we glance over past records, what do we learn about the numbers of defectives in former times and their numbers now? Describe how it is that through our kindness we have been helping on the misfortunes of the race. What have the fit been doing for the unfit? Was it right for us to lengthen the lives of our degenerates and maintain them in comfort? What was it that we should not have done? To a large extent, whose descendants are now multiplied in our asylums, our prisons, and our hospitals? To whom must the new road which humanity travels be dedicated? What does common sense tell us will be the result if we protect children before they are born? If we should do this, what would be the result in the future?. What does race regeneration really mean? How can race regeneration come? What does race regeneration command each generation to do for the next generation? What is the noblest gift which one generation may offer to another? From whom has each of us received his standards of life? 


\section{A PARTIAL LIST OF BOOKS USED IN THE PREPARATION OF THIS VOLUME}

Bateson, W. Mendel's Principles of Heredity. I9I3.

Bezzola, Dr. D. Statistische Untersuchungen tiber die Rolle des Alcohols bei der Entstehung des originären Schwachsinns. 1902.

Bunge, G. Alcoholic Poisoning and Degeneration. Journal of Inebriety. 1900.

Castle, W. E. Heredity in Relation to Evolution and Animal Breeding. 1911.

Castle, W. E. Heredity of Coat-Characters in Guinea-Pigs and Rabbits. 1905 .

Conn, W. H. The Method of Evolution. I900.

DARWIN, C. The Origin of Species. I864.

DARWIN, C. Naturalist's Voyage round the World. Third edition, I860.

DARWIN, FRAXCIS. Life and Letters of Charles Darwin. I887.

Davenport, C. B. Eugenics. IgIo.

DAVENPORT, C. B. Heredity in Relation to Eugenics. IgII.

Dock, L. L. Hygiene and Morality. Igro.

Ellis, Havelock. The Problem of Race-Regeneration. I9I I.

Fisher, Irving. National Vitality. Igo8.

Galton, F., and Sciruster, E. Noteworthy Families. 1906.

GodDard, H. H. Heredity of Feeble-mindedness. I9II.

GodDard, H. H. Elimination of Feeble-mindedness. I9I I.

Goddard, H. H. The Menace of the Feeble-minded. I9II.

GodDard, H. H. The Kallikak Family. 1912.

Goldmark, Josephine. Fatigue and Efficiency. I9I2.

Gulick, J. T. Evolution, Racial and Habitudinal. 1905.

HALL, G. S. Adolescence. 1905 .

HaRwood, W. S. New Creations in. Plant Life. 1906.

Horsley, Sir Victor, and Sturge, Mary D. Alcohol and the Human

Body. 1908.

Howard, W. L. Plain Facts on Sex Hygiene. IgIo.

Jordan, David Starr. The Heredity of Richard Roe. I9I I.

KellicotT, W. B. The Social Direction of Human Evolution. IgI I. 
Metchnikoff, Elie. The Nature of Man. 1903.

Morrow, Prince A. Social Diseases and Marriage. 1904.

Pearson, Karl. Nature and Nurture. 1910.

STOCKARD, C. R. An Experimental Study of Racial Degeneration in

Mammals treated with Alcohol. Article in Archives of Internal Mledicine. Ọctober, 1912.

Thomson, J. A. Darwinism and Human Life. I9II.

Thomson, J. A. Heredity. 1908.

Tower, W. L. Evolution in Chrysomelid Beetles. 1908.

Treasury of Human Inheritance. Publications of the Francis Galton

- Laboratory for National Eugenics," 1909-1912.

Tylor, E. B. Primitive Culture. I874. 


\section{INDEX}

Key to pronunciation : fāte, senàte, făt, ärm, ảsk ; mēte, èvent, mět, hẽr; ice, it ; ōld, òbey, nŏt; ưnite, ŭp; obscure sounds : a

Acquired characters, definition of, 73 , n. ; illustrations of, $73,74,75$; contrasted with mutations, 80

Adolescent era, 1 29-135

Alcohol, effect of, on chicks, i 18 , I 19 ; effect of, on guinea pigs, I 19; effect of, on descendants, I 22I 25 ; relation of, to feeble-mindedness, 122, 1 25, 186; as a beverage, $145^{-1} 5^{2}$; effect of, in surgery, 146; effect of, on brain cells, I 46

Amaryllis, new variety of, 29

American Museum of Natural History, horse bones shown in 34

Amœba (a mé'ba), multiplication of, IOI, $\mathrm{IO}_{3}$

Ancestral reminiscence, 68

Andalusian fowls,. 7-II ; results of mating, 9; color inheritance of, Io

Angleworms studied by Darwin, 43,44

Annapolis, entrance examinations for, showing weak heart, I 4 I

Aosta, the cretins of, 181,182

Arizona, horse bones found in, 38

Ashby, Dr., 199

Austria, 27

Babies, growth of, described by Dr. Minot, II 5; health of, I 7 ; eye treatment of, 177

Bataillon, Professor, $100^{\circ}$

Beagle, 45, 46, 48, 5 I

Beetles, effect of damp heat upon, 97-99
Bern, families studied in, 122

Bering's Strait, 48

Bethnal Green, condition of, in 1848 , I96, 197

Bezzola, Dr., I 22, 123, I 25

Biffen, Professor R. H., 27

Birds, survival of, in winter, 60 ; beaks of, in illustration, 85,86

Blincoe, Robert, I9o

Blindness, case of, in hotel, I74; cause of, I74, I75; prevention of, 177 , I 80

Blood, transfusion of, $145,1_{4} 6$

Boll weevil, harm done by, 29

Boston reached by potato bugs, 90

Brachydactylism (brăk ǐ dăk'tǐ lǐzm), definition of, 77 ; studied through five generations, 79

Brain, effect of alcohol on, 146-1 48 ; inhibition centers of, I47; order of development of, 147 ; advantage and disadvantage of, 160 ; the crown of evolution, 160

Brontosaurus, I 54

Briinn, 20

Burbank, Iuther, 28, 30, 3 I

Cactus, with thorns and without, $3^{I}$

Canada invaded by the potato bug, 90

Canneries, children at work in, 193

Castle, Professor IV. E., 12, I3, I4, I 6,17

Cats, short-tailed, 75

Chapple, Dr., 147

Characters defined, 12 
Chicks, study of, by Dr. Minot, I 10, I I ; comparison of, with rabbits, I14; influence of alcohol upon, i 8 , i 19

Childrén, description of overworked, 189-195; effect of overworked, on community, 195; protection of, before birth, 202-204

Civilization, modern and ancient contrasted, 156

Claxton, Mr., I92

Cleanliness, modern movement toward, 197

Coal mine, boys at work in, 192

Codfish, illustrating prodigality of nature, 57 ; in illustration of the five-linked chain, 63

Columbus, 47

Commissions for the blind, work of, 176,177

Conversion, age of, 127

Corn, fields of, compared, 27,28

Correns, 25

Cotton mills, work of children in, 189

Crab, 68

Cretins (krē'tǐnz), description of, by Dr. Jordan, I8I, 182

Cuba, yellow fever in, 60

Dandelion seeds, 56,57

Daniels, Secretary, I 5 I

Darwin, Charles, 42, 43, 47, 48, 49, $5 \mathrm{I}, 52,53,55,62,63,65,67$

Demm, Dr., 122

Depew, Senator, 143

De Vries, Professor, 25

Dock, Miss Lavinia, 168

Dogfish showing gill-slits, 64

Dominant defined, I 5

Drinking cup, public, why discarded, I $69-170$

Edwards, Jonathan, 2, 3

Eggs, of fish, $105-107$; of birds, 107 ; importance of, 108, ro9; subjected to alcoholic fumes, i 8 , I 19

Ellis, Dr., 134, I85, 199

Elm tree seeds, 56,57

Embryo, definition of, 65 ; gill-slits in, 65; resemblances of different ones in early stages, 112 ; development of, II 3
Environment, adaptation of potato bugs to, 92-94; effect of, in producing species, 95-99; for children, 199; milk as part of, 200; effect of, on descendants, 202

Evolution, of the horse, 34-42; shown on hind foot of the horse, 37 ; evidences of, $64-70$; crown of, 153,160

Family, as unit of society, I6r ; position of, in civilization, 162 ; health of, 162,164

Feeble-mindedness, I $8 \mathbf{I}$; numbers suffering from, $\mathrm{I} 83$; inheritability of, 185, I 88 ; prevention of, 188

Feet, as bound in China, 73, 74

Fire, making of first, I 57

Fish, method of their multiplication, 105,106

Forel, Dr., I 18, I19, 168

Fossil bones, definition of, 34 ; revelations made by, 40; in South America, 45, 47

Frogs, eggs of, under treatment, 100 ; metamorphosis of, 102; effect of nicotine on, 140

Galapagos Islands, 48, 49, 5I

Games, kissing, I 65

Gamete (găm'êt), Io3, 106

Geologist, study of bones by, 39

Germ cells, influence of environment on, 96, 97; union of, 101 ; purpose of, 103,104 ; similarities of, 104; life conditions of, 107 , I08; multiplication of, I11, I12; damaged by alcohol, I I 8-125

Germ plasm, significance of, 105

Gill-slits shown in dogfish, 64

Goddard, Dr. H. H., I 86

Goiter (goi'tẽr), I 8 I, I 82

Goldmark, Miss, 194

Gonococcus (gǒn ô kǒk'us), I 74

Gordon, Dr., I 21

Guinea pigs, why used, 12; color of, 13 ; length of hair, I4; albino defined, 14; color inheritance in, 1 5, 16; combined inheritance in, 17, I8; effect of alcohol upon, II $9-121$ 
Gulick, Dr. J. T., 8 I $, 82,8_{3}, 8_{4}, 8_{5}, 8_{7}$

Gulick, Dr. L. H., I26, I 27, I 28

Hapsburg jaw, I 59

Hawaiian Islands, description of, $8 \mathrm{I}, \mathrm{n}$.

Heinzendorf, 20

Heredity, Darwin's law of, 62

Hereford cattle, 32

Holstein cattle, 33

Horse, the evolution of, 34-42 ; ancient and modern compared, $4 \mathbf{I}$

Howard, Dr., I 73 , I 74

Hurty, Dr., I82, I 83

Hybrid (hî'brìd), definition of, 8

Hyracotherium (hĩ ra kô thế'rĭ unm), $3^{8}$

Imprisonment, age of, I 30

Inheritance, study of, withneighbors, 2 ; study of, through descendants of Jonathan Edwards, 3 ; study of, through the Jukes family, 4 ; in Andalusian fowls, $7-1 \mathrm{I}$; in guinea pigs, 12-19; in garden peas, 2025 ; laws of, put to use, 26 ; studied through rudiments, $65-70$; social, I43, I 58; relation of, to feeblemindedness, I $8_{4-I} \mathrm{~S} 8$; relation of, to race regeneration, $20 \mathrm{I}-204$

Isolation, as a factor in evolution, $81-87$; different kinds of, summarized, 87

Japan, dwarfed trees in, 74, 75

Jersey cow, 32, 33

Jordan, Dr. David Starr, 68

Joumal of the American Medical Association, 165

Jukes, the family of, 4 ; expense of, to New York State, 6

Kallikak family, history of, 186-I87

Kansas, invasion of, by the potato bug, 88

Kelley, Mrs. Florence, 192

Kellogg, Dr., I 40

Koko Head, 83

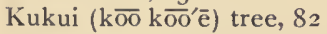

Lambert, Dr. Alexander, 190

Language, beginnings of, I 56
Loeb, Professor, I00, I0I

Leptinotarsa (lěp'tĭ nò tär'sa) decemlineata (dē sěm lǐn è ä'tâ), environment for, 88, 94; time of, spent underground, 93

Leptinotarsa melanothorax (měl a nờthō'răx), as it feigns death, $9 \hat{8}, 99$

Leptinotarsa multitanita (mŭl tî tếnǐ ta), as it feigns death, 98,99

Lungfish, description of, 7 I

McKeever, Dr., I 36, I 37

Manchester, epidemic in, I9I

Maple seeds, abundance of, 56,57

Matthew, Dr., $36,38,40$

Mendel, Gregor Johann, 20, 22, 23, $24,25,54$; laws of, stated, 24

Mendelism, 24

Meylan, Dr., I 42

Microbes, and kissing, 165, I66; and blindness, $173,174,176$; of gonococcus, methods of travel of, 178 ; of disease, discovery of, 202

Minot, Dr., I 10, I I 5, I I6, I I7

Mississippi River crossed by the potato bug, 90

Morehead, Dr., I79

Morrow, Dr., I68, I 72

Mutations, definition of, 75 ; as studied by Hugo de Vries, 78 ; as contrasted with acquired characters, 80 ; varieties of, 99

National Association of British and Irish Millers, 26, 27

Nebraska, horse bones found in, 38

Neisser, Dr., 174

Nicotine, and adolescence, I 36, I 44 ; course taken by, to reach heart, I 4 I

North America, 48

Oahu, island of, $81,82,93$

Ohio, effect of winter in, on birds, 60

Omaha, potato bug starts eastward from, $89,91,92$

Oregon, horse bones found in, $3^{8}$

"Origin of Species," publication of, 54

Osborn, H. F., 39

Osler, Dr., I 68

Oviparous (ò vịp'a russ), i 15 
Oxygen, how secured by fish and by land animals, 64,65

Oysters, illustrating prodigality of nature, $5^{8}$

Paleontologist (pā lè ŏn tǒl'ò jĭst), work of, 40

Paraguay, 75

Pasteur, Louis, 202

Patriotism, modern type of, I 64

Peas, color inheritance in, 2 I ; dominant and recessive characters of, 22 ; inheritance of seed characters in, 23

Pig, Poland China, I

Pigeons, different kinds of, 5 I, 52

Plum, development of, 31

Plymouth, typhoid epidemic in, 60

Polydactylism (pŏl ì dăk'tǐ lìzm), illustration of, 76 ; definition of, 77

Poppy, improvement of, 30

Potato, increased value of, 29

Potato bugs, migrations of, 88-94; comparison of, with IIawaiian snails, 93, 94

Potter, Mr., I93

Poulton, Mr.; 76

Prodigality, Darwin's law of, $5^{8}$

Pure-bred, definition of, I 8

Rabbit, generations of, each year, I 2; condition of, at birth, I 4

Race improvement, three steps in, I96-i99

Race regeneration, 20I, 204

Recessive character defined, I 5

Rochester, clean milk in, 200

Rorqual, giant whale, 69

Rudiments, definition of, 65 ; in calves, 65 ; in the whale, 65 ; Darwin's statements about, 67 ; proving history of whale, 67

Sacculina (săk ư līna), description of, 66,67

Schamberg, Dr., I 65, 166

Scott, Professor, 77

Seaver, Dr., I 4 I

Sex, significance of, I 62

Sheep, varieties of, 31, 32 ; shortlegged, 76

Shoes, Chinese, 73
Snail shells, studied by Dr. Gulick, $81-87$; reasons for so - many species of, 87

Social inheritance, 143

Sommerville, Lord, on sheep breeding, 54

South America, 45, 48, 49, 51; size of animals in, 47 ; death of animals in, for lack of water, 60

Spargo, Dr., I 99

Species, description of, 50, n.; influence of environment on, 95, 99

Spencer, Herbert, reference to, $6 \mathrm{r}, \mathrm{n}$.

Sperm cells, I06, 107

Sphygmograph (sfig'mò gräf), tests with, on tobacco users, I 36-139

State Liquor Dealers of Ohio, I49

Stockard, Dr., 1 I9, I 2 I

Struggle for existence, the law of, 58,59

Survival of the fittest, the law of, 61

Switzerland, studies of feeblemindedness made in, I 22, 123

Syphilis (š̃f $\mathbf{i}$ liss), methods of communication of, 166-I 68 ; protection from, 17 I

Tadpole, from unfertilized egg, I oo, IOI; as influenced by environment, I 14

Tertiary Bad Lands, mention of, 40

Thompson, Dr., 57, $5^{8}$

Thyroid (thī'roid) gland, I 81

Tobacco, why used by boys, I 32 ; effect of, on heart action, I 36 , I39; double nature of, I40; effect of, on Yale students, I4I-; use of, studied by Dr. Meylan, 142

Tower, Dr., 8o, 89, 90, 92, 93, 96, $97,98,99$

Toxodon (tǒk'sò dŏn), description of, 46

Treves, Sir Frederick, 146

University of Chicago, The, 96

Variation, Darwin's law of, 60

Vertebrates, evidences of similarity in, 70; individual life of, how started, IOI; four statements in regard to, I I 3 
Vineland, as " a great human laboratory," I $\delta_{3}-185$; methods adopted by, I $83,184,188$

Viviparous (vĩ vǐp'aruss), I I 5

Watt, James, I 57

Weismann, Professor, 73, 105

West Point, failure in entrance examinations to, I4I
Whale, its double change, $6 \mathrm{~S}$

Wheat, variety in heads, 26; Professor Biffen's work with, 27

Wilson, Dr., I79

Wirthwein Hall, 149

Zoölogical Laboratory of Harvard University, I2

Zoölogist, definition of, 65

Zygote (zi'́r gōt), definition of, $106 \mathrm{n}$. 

ANNOUNCEMENTS 



\section{THE PRINCIPLES OF BREEDING : THREMMATOLOGY}

By Eugene Davenport, Dean of the College of Agriculture, Director of the Agricultural Experiment Station, and Professor of Thremmatology in the University of Illinois

$8 \mathrm{vo}$, cloth, 727 pages, illustrated, \$2.50

"Principles of Breeding" is a pioneer in the worthy endeavor to. collate with the practical side of breeding the results of recent research in the processes and factors which govern the evolution of plants and animals. It sets forth the tasks involved in improving plants and animals, and familiarizes the reader with the methods employed for the quantitative and accurate determination of the extent and range of variability. It is therefore a book for both the student of agriculture in college and the practical breeder on the farm.

\section{DOMESTICATED ANIMALS AND PLANTS}

By Eugre Davenport, Dean of the College of Agriculture, Director of the Agricultural Experiment Station, and Professor of Thremmatology in the University of Illinois

8 vo, cloth, 321 pages, illustrated, \$1.25

THE aim of this work is to stimulate a widespread interest in domesticated animals and plants - to account for their origin, describe their life in the wild, explain their appropriation by man, show our dependence upon their services, state clearly the methods and principles of their further improvement - and, incidentally, to explain heredity in such a simple way as to bring within the range of the young student and the general reader the main facts of transmission, applicable alike to plant and animal improvement, and to human relations as well.

The literature of this subject is too intensely technical for the ordinary reader. The endeavor has been to make this book so simple and clear that it may be adapted alike to the secondary school, normal school, college, and to the needs of the general reader. 


\section{THE HUMAN MECHANISM}

\section{ITS PHYSIOLOGY AND HYGIENE AND THE SANITATION OF ITS SURROUNDINGS}

By Theodore Hough, Professor of Physiology in the University of Virginia, and William Thompson Sedgwick, Professor of Biology in

the Massachusetts Institute of Technology

IN ONE VOLUME. $12 \mathrm{mo}$, cloth, 564 pages, illustrated, partly in color, $\$ 2.00$. IN TWO VOLUMES. Volume 1. Elements of Physiology. 12mo, cloth, 321 pages, illustrated, \$1.25. Volume 11. Hygiene and Sanitation. 12mo, cloth, 270 pages, illustrated, $\$ 1.25$.

THE recent advances in our knowledge of personal and public 1 hygiene and of sanitation have made indispensable for the use of progressive educators a practical and authoritative textbook of what may be called "the new physiology and hygiene." The present work has been prepared in recognition of this need. Professor Hough has been engaged in the study and teaching of physiology and personal hygiene for over ten years. Professor Sedgwick has had a large share in the advancement of the study of public health and sanitation in America. They have made the keynote of this work the right conduct of the physical life, and to this end everything else is subordinated. Anatomy and histology are only briefly outlined, while special chapters are devoted to practical matters of hygiene and sanitation.

The authors believe that the matter and method of this new textbook will go far toward rescuing physiology and hygiene from the neglected and too often despised place which they now occupy in schools, and promoting them to one of practical usefulness and corresponding esteem.

The book is intended for high schools and normal schools, and for short courses in colleges. 


\section{A TEXT-BOOK IN GENERAL ZOÖLOGY}

By HeNry R. Linville, Head of the Department of Biology, Jamaica High School, New York City, and HENRY A. KELly, Director of the Department of Biology and Nature

Study, Ethical Culture School, New York City

462 pages, illustrated, \$1.50

$A^{\mathrm{s}}$

exposition of the science of zoölogy, presented without the interpolation of a laboratory guide.

Four years spent in careful examination of the original sources have resulted in a book filled with valuable material. The authors, through their extended service as teachers of biology in secondary schools, are well equipped for the task of writing a text-book designed, as this one is, chiefly for high-school use, although intended also to be available for elementary college classes.

The structure, the physiology, and the natural history of selected types of animals are described with accuracy and in language easily understood by young students.

The treatment of the subject is broad, and the inductive method is employed so far as each class and phylum of invertebrate animals is concerned. The definition of a group is not given until the student's conception of the group characters has grown to the point where the definition forms the fitting end to the logical process involved in the exposition.

The Insecta are discussed in the first chapters, and after the remainder of the Arthropoda are described, the other invertebrate phyla follow in a descending series, ending with the Protozoa. Then, beginning with the fishes, the order ascends to the mammals and closes with man.

A large portion of the book is devoted to the insects and vertebrates, because young students are more familiar with these groups and so take greater interest in them. The less known, however, are treated with care, the different features of morphology, physiology, and relation to environment being maintained in good measure throughout.

The book includes two hundred and thirty-three illustrations.

\section{GINN \& COMPANY Publishers}




\title{
TEXTBOOKS IN BIOLOGY
}

\author{
FOR HIGH SCHOOLS AND COLLEGES
}

\section{BOTANY}

Bergen : Elements of Botany. With Key and Flora (Revised Edition)

Without Key and

Bergen: Essentials of Botany. With Key and Flora . . . 1.50

Without Key and Flora . . . . . . . . . . . I.20

Bergen: Foundations of Botany. With Key and Flora . . I.50

Without Key and Flora . . . . . . . . . . . . I.20

Bergen: A Laboratory and Field Manual of Botany . . . 90

Bergen: Notebook to accompany Bergen's Botanies . . . .45

Bergen and Caldwell : Practical Botany . . . . . . I.30

Bergen and Davis: Principles of Botany . . . . . . . 1.50

Clute : Laboratory Botany . . . . . . . . . . . . $\quad .75$

Frye and Rigg: Laboratory Exercises in Elementary Botany .60

Meier: Herbarium and Plant Description . . . . . . .65

Meier: Plant Study (Revised Edition) . . . . . . . . .75

Nelson: Spring Flora of the Intermountain States . . . . $\quad .75$

Penhallow : Manual of North American Gymnosperms . . 4.50

Pepoon: Representative Plants . . . . . . . . .60

\section{ZOÖLOGY}

Linville and Kelly: Textbook in General Zoölogy . . . . I.50

Linville and Kelly: Guide for Laboratory and Field Work

in Zoölogy . . . . . . . . . . . . . 35

Meier: Animal Study . . . . . . . . . . . . . .75

Pratt: Course in Invertebrate Zoölogy . . . . . . . . 1.25

Pratt: Course in Vertebrate Zoölogy . . . . . . . . 1.50

Sanderson and Jackson: Elementary Entomology . . . . 2.00

\section{PHYSIOLOGY}

Blaisdell: Life and Health . . . . . . . . . . . 90

Blaisdell : Practical Physiology . . . . . . . . . I.IO

Brown: Physiology for the Laboratory. . . . . . . . .75

Hough and Sedgwick: The Human Mechanism . . . . 2.00

Volume I . . . . . . . . . . . . . . . . 1.25

Volume II . . . . . . . . . . . . . . . . . 1.25 
(n) 



\section{SUPPLEMENT TO}

\section{THE NEXT GENERATION}

BY

FRANCES GULICK JEWETT

\section{GINN AND COMPANY}

BOSTON · NEW YORK · CHICAGO - LONDON

COPYRIGHT, 1914, BY ERANCES GULICK JFWETT 



\section{ADDITIONAL FACTS ABOUT RACE HEALTH}

Recently a series of thirteen questions was sent to the college Young Men's Christian Associations of the United States. It was desired to know whether or not our college students are being taught about such laws of right living as pertain to personal morality and to race health.

Answers came from sixty-three prominent colleges and universities, located in all parts of the country. Dr. Exner's report ${ }^{1}$ says: "The replies show that every one of the sixty-three institutions from which replies were received make some provision for educating students in these matters." The report also shows that this education is of great advantage to the universities, although, as stated, "only one of these gives the result in figures. This is a large eastern institution which one of our strongest lecturers has visited regularly for four years, and where the college Association has done effective work with the use of literature. From this institution the report is that venereal disease has decreased So per cent, ... . that the attitude of coarseness and vulgarity toward the subject of sex has given place to serious respect, and that the whole moral tone of the institution has been changed. This report comes from reliable and conservative sources, and the figures are obtained through the university physician."

Other quotations from other institutions combine to prove that when young people know the facts they are usually ready to respond with right living. It is evident, then, that ignorance and thoughtlessness are largely responsible for the present widespread dispersion of such diseases as peculiarly imperil the future of the race.

"The Next Generation" was written to help remove this ignorance, and this Supplement to the book is presented separately because the facts given here are not for classroom use or for public discussion. It is important, however, that they should be read by all who are prepared

1 "Facts Relating to Sex Education in Colleges and Universities." Compiled by M. J. Exner, M.D., Secretary Student Department of the International Committee of Young Men's Christian Associations. 
for them through acquaintance with such material as is given in "The Next Generation." It is preferable that the reading of these facts should come after and not before the book itself is studied.

Chapters XXIII and XXIV of "The Next Generation" give information about the contagious nature of two diseases, syphilis and gonorrhea, which, at the present time, are more destructive to the race than any other forms of disease from which humanity suffers.

Syphilis is caused by a microbe called Spirochaeta pallida. This microbe may be transmitted from person to person through abrasions of the skin, as shown in Chapter XXIII, and it is likely to be found in the bodies of those who live immoral lives. Syphilis may ruin not only the diseased man, but also his wife, his children, and his children's children. This is the one disease of man that travels by inheritance from one generation to the next.

Dr. Morrow says: "Fully one third of all syphilitic children born alive die within the first six months," or, " escaping early death, they may yet suffer from the disease in their twentieth or thirtieth year, or even later."

Dr. Hodge writes: "The cough spray of a syphilitic may be more dangerous than the discharge of a gun into a person's face."

No one knows whence the disease first came, but all know that at present fallen women give it to men who visit them; that these men pass the disease on to healthy women whom they marry; that, once it has entered the stream of family life, no power of man can keep it from doing its work of devastation. All know that wives thus diseased become permanent invalids; that they endure surgical operations and are not cured; that their babies die needlessly, and that other little ones live to suffer.

In such cases a mother often blames herself for the endless chain of woe that has encircled herself and her babies. She does not know that generally the cause of it all is the disease caught in his ignorant youthi by the man she married - a man who thought he was cured before the wedding day came.

Until recently young men and women have been allowed to pass through the adolescent era and to enter the life of maturity utterly ignorant of their temptations and their dangers. For the safety of the race and for their own safety these guardians of the stream of life should know how to protect themselves. 
Many women learn the lesson too late. It was of such a woman that my friend spake. She said: "I knew her as a girl, healthy and vigorous, and I knew her when she died, a wreck. She was married at nineteen. He was a handsome, dashing fellow. They had two children. In course of time she began to be ailing. She grew worse, suffered terribly, and at last the end came. We were all in the room-her mother, her sister, and I. She was lying back on her pillow, barely breathing, when her husband came in. An expression of horror swept across her face. She half raised herself on her elbow, pointed her finger toward him, and in a husky whisper said: "You did it, and you know it. You 'ye killed me." Then she fell back dead.

It is because of cases like this one (and they might be multiplied by the tens of thousands) that state after state of the United States is passing the law that any person about to be married shall first secure a medical certificate stating that the bearer of it has no contagious disease.

As soon as women realize the need, they themselves will insist on this. Even now some intelligent fathers require such a certificate of the men who wish to marry their daughters. And every healthy man is glad and proud to be able to give it. In course of time the demand will be universal. In the meantime let a girl refuse the intimate companionship of any man who is morally weak. Let her refuse to marry him. The chances are that such men are also physically diseased.

Practically all women who lead immoral lives are diseased some of the time, and some of them all the time. They are centers of infection. On the average, such women live about six years after beginning to lead this life.

The following is a true family history. It was told to me by one who knew the persons.

The father of the family had committed two sins - one against himself, the other against his family. I state them side by side for the sake of comparison. In his early manhood he had been immoral and contracted syphilis; he was treated by the doctors and counted himself well. After this he married. Thirty years later he began to lose control of his judgment. In business, where he had been keen-sighted before, he now made strange mistakes - slight at first but increasingly serious. Months passed and his mind grew constantly less efficient, until at last he could be trusted with no business whatever.

Finally, he lost his mind so completely that he was put into an insane asylum. The cause of it was the disease taken when he sowed wild oats 
in his youth, and which he harbored in his system until, as old age approached, his body lost its power of resistance. The lurking disease then gained the upper hand and conquered him. Thus it was that the man's own sin defeated him.

In addition he dragged others down with him. The bẻautiful woman whom he married was ignorant of his past history and entirely ignorant of the laws of family health. They had several children. The first two were syphilitic and died at birth. The diseased germ cells of the father explained this.

The third baby seemed normal until he was four years old, when he showed syphilitic symptoms and mercifully died shortly afterwards.

The fourth child is still living with his mother in New England. He is thirteen years old. Until a year ago he was unusually bright. He attended school and did remarkably well for a while. Then a cloud began to show itself. Little by little it is spreading over his whole mind. $\mathrm{He}$ still gets out his geography with pride and tells you facts he once learned. He tries to learn more facts, but the power is gone. He has had to stop going to school, and each day his mind becomes more vacant.

His mother watches the change in agony, but she is helpless. Her only son is being swept beyond her reach, and she knows it. At last also she knows the cause. She knows what it is that doomed him. She knows why all her children have suffered such ruin. She knows that in each case destruction came through the father.

This, then, was the greatest sin of the man - not that he destroyed himself, although this was sad enough, but that he crushed the lives of his innocent wife and his helpless children. And the reason he did it was that he did not know the danger and that he did not control himself in his youth. He was ignorant.

This is but a single instance where thousands might be given.

No right-minded woman would, with her own hands, prepare herself for cruel suffering; neither would she willfully kill her baby. Yet any woman who, knowing the danger, allows herself to marry a man who is not morally upright and physically pure invites the tragedy and the suffering which lies in wait for her and for her children.

No right-minded man would, willfully and with his own hands, kill his helpless baby, yet any man who, knowing the facts, dares to run the risk of contracting this dread disease is as guilty as if he had killed his own children with his own hands. 
The second of these terrible diseases - the one which may produce blindness at birth - is named gonorrhea. It is caused by the gonococcus microbe, and it starts in the same general way as syphilis. The great source of both is with those who live immoral lives. Very often the same person has both diseases.

The gonococcus microbe needs no broken surface through which to travel; neither does it produce a visible sore, as does syphilis. When a moist membrane, diseased with gonococcus microbes, touches a healthy, moist membrane, the microbes go across and begin their work of destruction. From their starting point they creep upward in the body, traveling over the lining membrane of one slender tube after another, carrying disease to each, until at last they reach the vital organs. In tens of thousands of cases the inflammation within the tubes is so extreme that they become hopelessly scarred, and because they are scarred they contract and at last close entirely. After this no germ cell is able to pass through them from the body, and all chance for the beginning of another generation is cut off. In other words, the person becomes sterile.

In one important respect this disease differs from certain other contagious diseases. Persons who have had smallpox are considered safe from another attack. So also are those who have had measles and mumps and scarlet fever. But with this disease the mere fact that a person has had it once increases the chance of his having it again if he is again exposed to it. And then, as Dr. Forel says, "When this disease becomes chronic, relapses of the acute stage often occur without fresh infection." He adds: "In women the results of gonorrhea are, if possible, still worse than in men. Women affected with chronic gonorrhea generally become sterile."

Already society is trying to protect itself against smallpox and leprosy, against whooping cough, measles, scarlet fever, tuberculosis, typhoid fever, yellow fever, and other communicable diseases. And yet there still remain these other two diseases which at present hold more suffering for this generation and the next than all the other diseases combined. In view of this situation, we now know that the prevention of these two diseases is the most important hygienic duty which faces the present generation. We know that, as a whole, the rising generation is clearheaded and sane, and that when it learns the facts, it will protect itself by prevention. It is evident, then, that the health and safety of the nation 
depend on what the young people of the land know and do not know concerning certain diseases which are so closely connected with evil that, until recently, their names have not been so much as mentioned except by scientists, doctors, and nurses.

\section{ADVICE FOR GIRLS}

The following was written about girls in England and for their special use, but it applies equally well to girls everywhere else. I quote the words as given.

"No girl can afford to accept attentions from any unknown man, however well dressed or well mannered he may be. This is especially true when girls are traveling from city to city, or from one part of a city to another part of the same city.

"Many girls have been entrapped into white slavery in England during the past months through the most diabolical methods. A woman dressed as a professional nurse has trapped a number. Men white slavers with drugged handkerchiefs or drugged flowers have trapped many. One large telephone company has issued warnings to all young women operators, telling them to pay no attention to messages received over the wires calling them to certain places on account of the illness of a relative or friend, etc."

One society has sent out printed warnings. Every girl in every country should give heed to them. The following are the warnings:

"Never speak to strangers, either men or women, in the street, in shops, in stations, in trains, in lonely country roads, or in places of amusement.

"Never ask the way of any but officials on duty, such as policemen, railway officials, or postmen.

"Never loiter or stand about alone in the streets, and if accosted by a stranger (whether man or woman), walk as quickly as possible to the nearest policeman.

"Never stay to help a woman who apparently faints in the street, but call a policeman at once.

"Never accept an invitation to join a Sunday School or Bible class, given by strangers, even if they are wearing a clerical dress.

"Never accept a ride offered by a stranger in a motor, a taxicab, or a vehicle of any description. 


\section{ADDITIONAL FACTS ABOUT RACE HEALTH ix}

"Never enter any house, restaurant, or place of amusement on the invitation of a stranger.

"Never go with a stranger (even if dressed as a hospital nurse) or believe stories of relatives having suffered from an accident or being suddenly taken ill. This is a common device to kidnap girls.

"Never accept sweets, food, or a glass of water or smell flowers offered by a stranger. So many things can contain drugs.

"Never take a situation through advertisements either in England or abroad without first finding out about it through responsible people.

"Never go to London or any large town for even one night without knowing of some safe lodging."

In all parts of the world to-day loyal-hearted men and women are doing what they can to help the girls save themselves. 



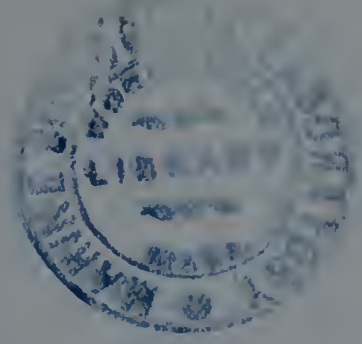


